A Comprehensive Study of LASL Well C/T-2 Roosevelt Hot Springs KGRA, Utah, and Applications to Geothermal Well Logging 
An Affirmative Action/Equal Opportunity Employer

Prepared by

Marge Wilson
Group G-1

This work was supported by the US Department of Energy, Division of Geothermal Energy.

This report was prepared as an account of work sponsored by an agency of the United States Covernment. Neither the United States Government nor any agency thereof, nor any of their employees, makes any warranty, express or impliod, or assumes any legal liability or responsibility for the accuracy, completeness, or usefulness of any information, apparatus, product, or process disclosed, or represents that its use would not infringe privately owned rights. Reference herein to any specific commercial product, process, or service by trade name, trademark, manufacturer, or otherwise, does not necessarily constitute or imply its endorsement, recommendation, or favoring by the United States Covernment or any agency thereof. The views and opinions of authors expressed herein do not necessarily state or reflect those of the United States Government or any agency thereof. 


\title{
A Comprehensive Study of LASL Well C/T-2 Roosevelt Hot Springs KGRA, Utah, and Applications to Geothermal Well Logging
}

\author{
Prepared for \\ Los Alamos Scientific Laboratory
}

by

William E. Glenn*

Jeffrey B. Hulen*

Dennis L. Nielson*

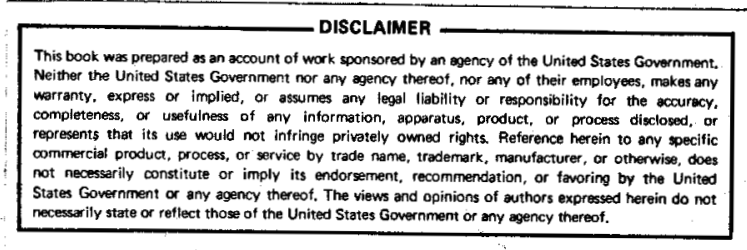

"Earth Science Laboratory Division/University of Utah Research Institute, 420 Chipeta Way, Suite 120, Salt Lake City, UT 84108. 


\section{DISCLAIMER}

Portions of this document may be illegible in electronic image products. Images are produced from the best available original document. 
CONTENTS

PAGE

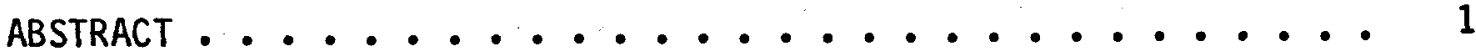

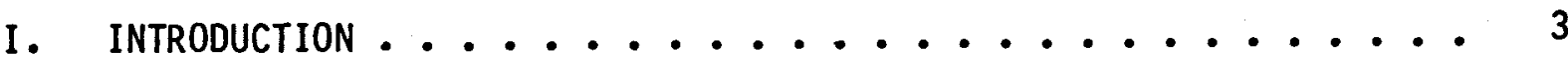

A. Background ..................... 3

B. Location ...................... 3

C. Geology of the Roosevelt Hot Springs KGRA .......... 5

II. LITHOLOGIC LOGGING AND ALTERATION STUDIES . . . . . . . . 9

A. Methods and Procedures ................ 9

B. Lithology, Alteration, and Inferred Structure ....... 15

1. Lithology ................ 15

a. Biotite-Quartz-Feldspar Gneiss ......... 16

b. Biotite-Pyroxene-Hornblende Diorite ......... 17

c. Hornblende-Biotite Granodiorite to Quartz Monzonite............. 21

d. Hornblende-Biotite Quartz Monzonite ......... 24

e. Hornblende-Biotite Granite ........... 26

f. Microdiorite and Andesite ............ 27

2. Alteration and Inferred Structure .......... 29 Discussion ....................... 34

3. Intervals Selected for Detailed Geochemical and Isotopic Investigation .......... 35

III. GEOCHEMISTRY ..................... 35

A. Introduction ................... 35

B. Methods and Procedures ............... 36

C. Geochemistry of Composite Samples . . . . . . . . . 38

D. Geochemistry of Detailed Study Intervals ......... 63

E. Rare Earth Element Analyses ............... 63

F. Fluid Chemistry .................. 77 
IV. OXYGEN AND CARBON ISOTOPE ANALYSES . . . . . . . . . 77

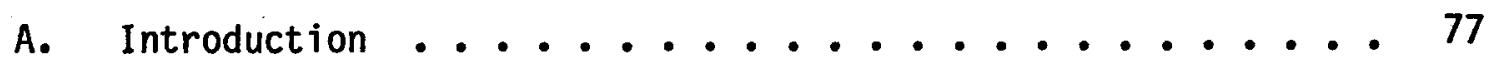

B. Sample Preparation and Analyses .......... 79

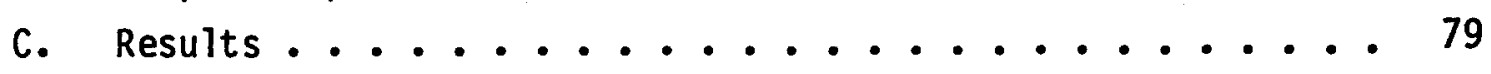

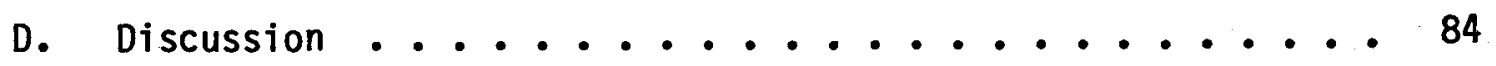

1. Frequency Distribution ........... 84

2. Isotope Geothermometry .............. 85

E. Identification of Fluid Entries .......... 88

v. PHYSICAL PROPERTY MEASUREMENTS ................ 92

A. Bulk Density and Magnetic Susceptibility ........ 92

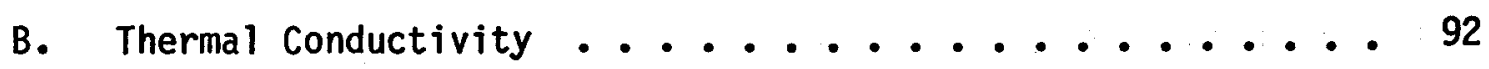

VI. GEOPHYSICAL INTERPRETATION ................ 105

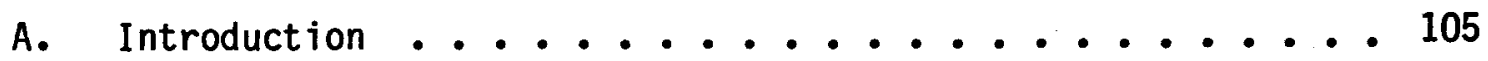

B. Log Descriptions ...................... 107

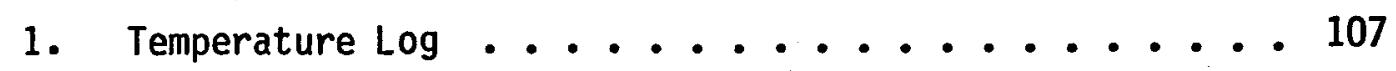

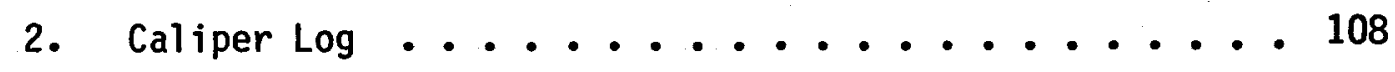

3. Acoustic (Velocity) logs ............ 109

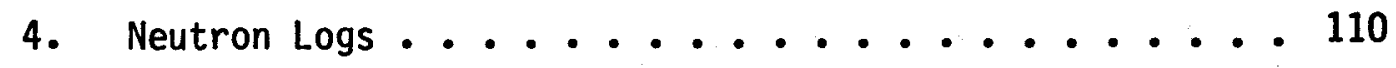

5. Density Logs .................... 117

6. Electrical Conductivity and SP Logs ........ 118

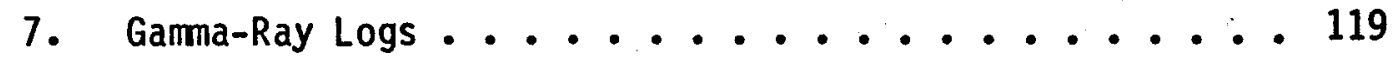

8. Summary Log Evaluations ............ 123

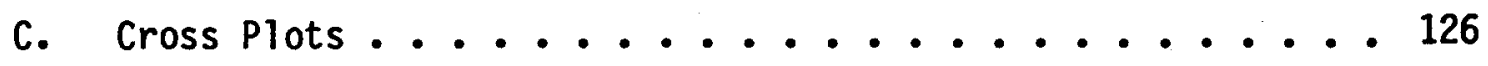

1. Basis for Plots ................... 126

2. Neutron-Density Cross Plots ........... 132

3. Neutron-Velocity Cross Plots . . . . . . . 136

4. Density-Velocity Cross Plots .......... 136

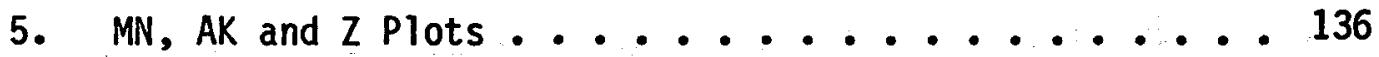

6. Gamma-Ray Cross Plots .............. 145

7. Log Data - Chemical Data Cross Plots ........ 157

D. Surmary of $\log$ Interpretations ................ 166 
ACKNOWLEDGEMENTS ............................... 168

REFERENCES .............................. 169

\section{TABLES}

Table 2-I Petrographic summary, selected samples from Well $\mathrm{C} / \mathrm{T}-2$.

Table 2-II Microprobe chemical analyses of selected rock-

forming and alteration minerals from Well C/T-2 ... 19

Table 2-III. Mineralogy of clay separates, selected samples

from Well $\mathrm{C} / \mathrm{T}-2$ as determined by $\mathrm{X}$-ray diffraction ... 30

Table 3-I Chemical analysis of composite samples

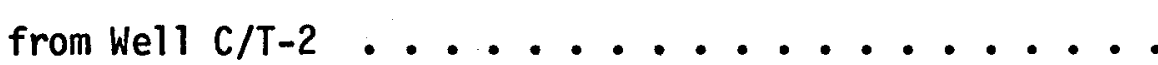

Table 3-II Chemical analyses of drill chip samples

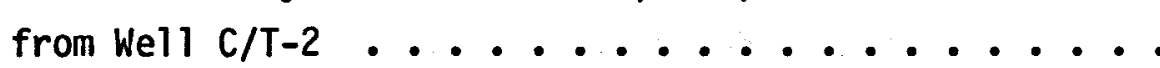

Table 3-III Neutron activation analyses of selected samples from Well C/T-2 ................. 75

Table 3-IV Water analyses from Well C/T-2 ........ 78

Table 4-I Oxygen and carbon isotope data from Well C/T-2 .... 80

Table 4-II Estimates of carbon and oxygen isotopic temperatures in

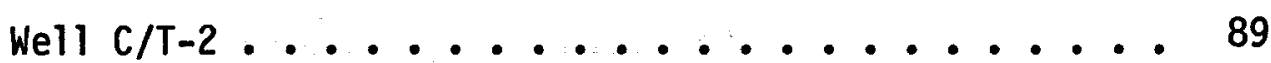

Table 5-I Magnetic susceptibilities and densities of cuttings from well $\mathrm{C} / \mathrm{T}-2 \ldots . . . . . . . . . . . . . .93$

Table 5-II Thermal conductivity measurements on chip samples in $\mathrm{C} / \mathrm{T}-2$ at $15^{\circ} \mathrm{C}$ and well bore temperatures ..... 103

Table 6-I Well logs obtained in C/T-2 by LASL . . . . . . 106

Table 6-II Comparison of the two neutron tool specifications and logging parameters in Well $\mathrm{C} / \mathrm{T}-2 \ldots \ldots 115$

Table 6-III Comparison of porosity values read from DA calibration curve and polynomial equation ...... 116

Table 6-IV Comparison of depths to various distinct features as seen on the different logs ......... 125 
Table 6-V Two arbitrary, generalized igneous/metamorphic rock compositions .............. 128

Table 6-VI Average and range of $\log$ values for the two rock types in the open-hole interval of $\mathrm{C} / \mathrm{T}-2 \ldots . . .166$

\section{FIGURES}

Figure 1-1 Location map ...............

Figure 1-2 Geologic map of a portion of the Roosevelt Hot Springs KGRA showing Well $\mathrm{C} / \mathrm{T}-2$ and other geothermal wells and shallow diamond drill holes ....... 7

Figure 1-3 Geologic cross section of the Roosevelt Hot Springs geothermal area showing Well $\mathrm{C} / \mathrm{T}-2 \ldots \ldots 8$

Figure 3-1 Composite whole rock analyses of Well C/T-2 as a function of depth ............. 57

Figure 4-1 0xygen isotope values as a function of depth

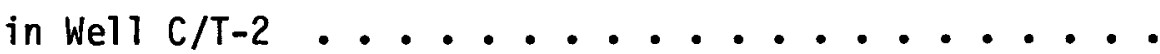

Figure 4-2 Carbon isotope values as a function of depth in

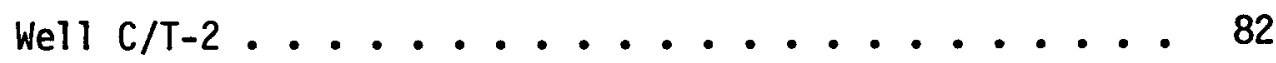

Figure 4-3 0xygen versus carbon isotope values from Well C/T-2 . 84

Figure 4-4 Frequency histograms of oxygen and carbon isotope values from Well c/T-2 ............ 86

Figure 4-5 Frequency histograms of temperatures calculated from oxygen and carbon isotope values from Well $\mathrm{C} / \mathrm{T}-2 \ldots . . . . . . . . . . . . . . .990$

Figure 4-6 Calculated oxygen and carbon isotopic temperatures plotted against lead values of composite samples from Well C/T-2 ................. 91

Figure 5-1 Plot of magnetic susceptibility vs density of cuttings from Well C/T-2 ........... 101

Figure $6-1$ Variable density acoustic logs .......... 111 
PAGE

Figure 6-2 Dresser Atlas vs Schlumberger Neutron: depth

interval 1280.9 to $1462.3 \mathrm{~m}$ (4202.5 to $4797.5 \mathrm{ft}$ );

$1.52 \mathrm{~m}(5 \mathrm{ft})$ data averages ........... 112

Figure 6-3 Dresser Atlas vs Schlumberger Neutron; depth

interval 1585.7 to $1767.1 \mathrm{~m}$ (5202.5 to $5797.5 \mathrm{ft}$ );

$1.52 \mathrm{~m}(5 \mathrm{ft})$ data averages ........... 113

Figure 6-4 Dresser Atlas vs Schlumberger Neutron: depth

interval 1890.5 to $2071.9 \mathrm{~m}(6202.5$ to $6797.5 \mathrm{ft})$;

$1.52 \mathrm{~m}(5 \mathrm{ft})$ data averages ........... 114

Figure 6-5 Dresser Atlas vs Schlumberger Gamma Ray:

depth interval 1158.5 to $1317.7 \mathrm{~m}$ (3801 to $4323 \mathrm{ft}$ );

$.61 \mathrm{~m}(2 \mathrm{ft})$ data averages ............ 120

Figure 6-6 Dresser Atlas vs Schlumberger Gamma Ray:

depth interval 1531.6 to $1744.3 \mathrm{~m}$ (5025 to $5723 \mathrm{ft}$ );

$.61(2 \mathrm{ft})$ data averages .............. 121

Figure 6-7 Dresser Atlas vs Schlumberger Gamma Ray:

depth interval 1958.3 to $2085.8 \mathrm{~m}$ (6425 to $6843 \mathrm{ft}$ );

$.61 \mathrm{~m}(2 \mathrm{ft})$ data averages ............ 122

Figure 6-8 Density vs neutron porosity cross plot grid

for "rock 1" composition in Table 6-IV . . . . . . 129

Figure 6-9 Density vs neutron porosity cross-plot grid

for "rock 2" composition in Table 6-IV ........ 130

Figure 6-10 Expanded scale version of Fig. 6-8 and includes

a demonstrated use of grid ........... 131

Figure 6-11 Bulk density vs neutron porosity: depth

interval 1752.5 to $1813.5 \mathrm{~m}$ ( 5750 to $5950 \mathrm{ft}$ );

$.61 \mathrm{~m}(2 \mathrm{ft})$ data averages ........... 133

Figure 6-12 Bulk density vs neutron porosity: depth

interval 1927.5 to $1957.9 \mathrm{~m}$ (6324 to $6424 \mathrm{ft}$ );

$.61 \mathrm{~m}(2 \mathrm{ft})$ data averages . ........... 134

Figure 6-13 Bulk density vs neutron porosity: depth

interval 2011.6 to $2072.5 \mathrm{~m}(6600$ to $6800 \mathrm{ft})$;

$.61 \mathrm{~m}(2 \mathrm{ft})$ data averages ........... 135 
Figure 6-14 Interval transit time vs neutron porosity: depth interval 1752.5 to $1813.5 \mathrm{~m}$ ( 5750 to $5950 \mathrm{ft}$ ); $.61 \mathrm{~m}(2 \mathrm{ft})$ data averages ............ 137

Figure 6-15 Interval transit time vs neutron porosity: depth interval 2011.6 to $2072.5 \mathrm{~m}(6600-6800 \mathrm{ft}) ; .61 \mathrm{~m}(2 \mathrm{ft})$

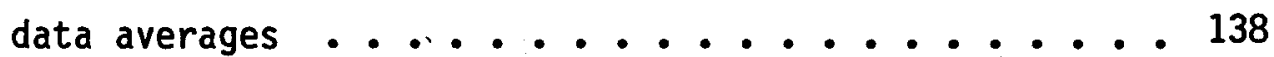

Figure 6-16 Bulk density vs interval transit time: depth interval 1752.5 to $1813.5 \mathrm{~m}(5750$ to $5950 \mathrm{ft}) ; .61 \mathrm{~m}(2 \mathrm{ft})$ data averages .................. 139

Figure 6-17 Bulk density vs interval transit time: depth interval 2011.6 to $2072.5 \mathrm{~m}(6600$ to $6800 \mathrm{ft}) ; .61 \mathrm{~m}$ (2 ft) data averages ............... 140

Figure 6-18 Bulk density vs neutron porosity: depth interval 1752.5 to $1813.5 \mathrm{~m}(5750$ to $5950 \mathrm{ft}) ; .61 \mathrm{~m}$

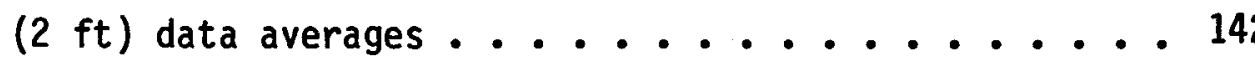

Figure 6-19 Bulk density vs neutron porosity: depth interval 1923.8 to $1957.9 \mathrm{~m}$ (6312 to $6324 \mathrm{ft}) ; .61 \mathrm{~m}$ (2 ft) data averages ............... 143

Figure 6-20 Bulk density vs neutron porosity: depth interval 2011.6 to $2072.5 \mathrm{~m}(6600$ to $6800 \mathrm{ft}) ; .61 \mathrm{~m}(2 \mathrm{ft})$ data averages .................. 144

Figure 6-21 Z-plot, bulk density vs neutron porosity with gamma ray in $Z$ direction: depth interval 1752.5 to $1813.5 \mathrm{~m}$ (5750 to $5950 \mathrm{ft}) ; .61 \mathrm{~m}$ (2 ft) data averages .............. 146

Figure 6-22 Z-plot, bulk density vs neutron porosity with gamma ray in $Z$ direction: depth interval 2011.6 to $2072.5 \mathrm{~m}(6600$ to $6800 \mathrm{ft}) ; .61 \mathrm{~m}(2 \mathrm{ft})$ data averages ................... 147

Figure 6-23 Gamma ray vs a) neutron porosity, b) bulk density and c) interval transit time: depth interval 1752.5 to $1813.5 \mathrm{~m}$ (5750 to $5950 \mathrm{ft}) ; .61 \mathrm{~m}(2 \mathrm{ft})$

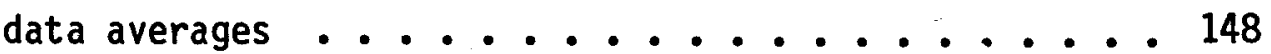


PAGE

Figure 6-24 Gamma ray vs a) neutron porosity, b) bulk density and $c$ ) interval transit time: depth interval 1923.8 to $1957.9 \mathrm{~m}$ (6312 to $6424 \mathrm{ft}) ; .61 \mathrm{~m}$

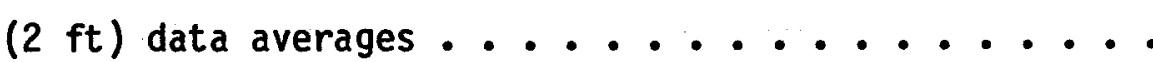
151

Figure 6-25 Gamma ray vs a) neutron porosity, b) bulk density and c) interval transit time: depth interval 2011.6 to $2072.5 \mathrm{~m}(6600$ to $6800 \mathrm{ft}) ; .61 \mathrm{~m}$

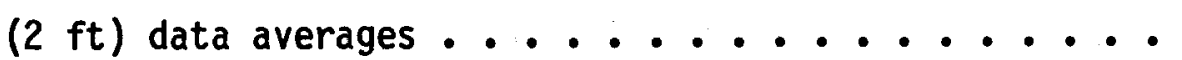

Figure 6-26 Gamma ray vs $\mathrm{K}_{2} 0$ : depth interval 1758.9 to $1804.4 \mathrm{~m}(5770$ to $5920 \mathrm{ft}) ; 3.1 \mathrm{~m}(10 \mathrm{ft})$ data averages .................... 158

Figure 6-27 Gamma ray vs $\mathrm{K}_{2} 0$ : depth interval 1905.0 to $1935.5 \mathrm{~m}(6250$ to $6350 \mathrm{ft}) ; 3.1 \mathrm{~m}(10 \mathrm{ft})$ data averages................ 159

Figure 6-28 Gamma ray vs $\mathrm{K}_{2} 0$ : depth interval 2023.8 to $2057.4 \mathrm{~m}(6640$ to $6750 \mathrm{ft}) ; 3.1 \mathrm{~m}(10 \mathrm{ft})$ data averages .................. 160

Figure 6-29 $\mathrm{Fe}_{2} \mathrm{O}_{3}+\mathrm{MgO}$ vs bulk density: depth interval 1761.7 to $1804.4 \mathrm{~m}(5780$ to $5920 \mathrm{ft}) ; 3.1 \mathrm{~m}(10 \mathrm{ft})$ data averages .................... 161

Figure 6-30 $\mathrm{Fe}_{2} \mathrm{O}_{3}+\mathrm{MgO}$ vs bulk density: depth interval 1908.0 to $1938.5 \mathrm{~m}(6260$ to $6360 \mathrm{ft})$; $3.1 \mathrm{~m}(10 \mathrm{ft})$ data averages ........... 162

Figure 6-31 $\mathrm{Fe}_{2} \mathrm{O}_{3}+\mathrm{MgO}$ vs bulk density: depth interval 2023.9 to $2057.4 \mathrm{~m}(6640$ to $6750 \mathrm{ft}) ; 3.1 \mathrm{~m}$ (10 ft) data averages ................ 163

Figure 6-32 Loss vs neutron porosity: depth interval 1761.7 to $1804.4 \mathrm{~m}$ ( 5780 to $5920 \mathrm{ft}), 3.1 \mathrm{~m}$ (10 ft) data averages .............. 164

Figure 6-33 Loss vs neutron porosity: depth interval 2023.9 to $2057.4 \mathrm{~m}$ (6640 to $6750 \mathrm{ft}$ ); $3.1 \mathrm{~m}$ $(10 \mathrm{ft})$ data averages ................. 165 
Figure A Log composite of LASL C/T-2 (Utah State Geothermal Well 9-1) Roosevelt Hot Springs KGRA, Beaver County Utah ................. microfiche

Figure $B$

Log composite of selected logs, LASL C/T-2 in pocket (Utah State Geothermal Well 9-1), Roosevelt Hot back cover)

Figure C Springs KGRA, Beaver County, Utah ........ microfiche Chemical, radiometric and $X$-ray fluorescence in pocket

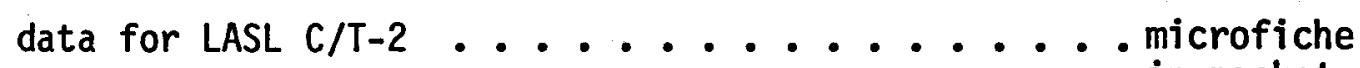

Figure $D \quad$ Chemical analysis (Loss, $\mathrm{MgO}_{2} \mathrm{Fe}_{2} \mathrm{O}_{3}$, and in pocket $\mathrm{Fe}_{2} \mathrm{O}_{3}+\mathrm{MgO}$ ) for LASL Well $\mathrm{C} / \mathrm{T}-2$ (Utah State Geothermal Well 9-1) ......... microfiche in pocket 
A COMPREHENSIVE STUDY OF LASL WELL C/T-2

ROOSEVELT HOT SPRINGS KGRA, UTAH, AND

APPLICATIONS TO GEOTHERMAL WELL LOGGING

by

William E. Glenn, Jeffrey B. Hulen, and Dennis L. Nielson

\begin{abstract}
Utah State Geothermal Well 9-1 in the Roosevelt Hot Springs KGRA, Beaver County, Utah, has been donated by Phillips Petroleum Company to the Los Alamos Scientific Laboratory (LASL) for calibration and testing of welllogging equipment in the hot, corrosive, geothermal environment. It is the second Calibration/Test Well $(C / T-2)$ in the Geothermal Log Interpretation Program. The Earth Science Laboratory/University of Utah Research Institute, on behalf of LASL, has completed a study of cuttings and well logs from Well C/T-2. This synthesis and data presentation contains most of the subsurface geologic information needed to effect the total evaluation of geophysical logs acquired in this geothermal calibration/ test well, C/T-2.
\end{abstract}

\title{
EXECUTIVE SUMMARY
}

Drill cuttings and well logs from LASL Well C/T-2 in the Roosevelt Hot Springs KGRA, Beaver County, Utah, have been studied in detail in order to characterize the well for calibration and testing of logging equipment. Well C/T-2, a) though hot (up to $227^{\circ} \mathrm{C}$ ) and deep $(2099 \mathrm{~m}$ ), encountered no significant thermal fluid production. A probable major fault zone crossed at $838.2 \mathrm{~m}$ separates Well C/T-2 into two distinct lithologic, structural and alteration regimes. Above this fault zone, highly variable Precambrian gneisses and mafic diorites of uncertain age with minor Tertiary granite and microdiorite are strongly 1 faulted, fractured, and moderately to intensely hydrothermally altered. Below the fault zone, mafic granodiorite of unknown age is intruded by thick 
intercepts of Tertiary quartz monzonite and granite with minor Tertiary microdiorite. Most of the alteration in $\mathrm{C} / \mathrm{T}-2$ is believed to predate the presently active geothermal system.

Whole-rock geochemistry reveals anomalous concentrations of mercury, arsenic and lithium in the fractured and altered rocks above the major fault at $838.2 \mathrm{~m}$. Enrichment of these elements is believed to indicate geothermal fluid circulation. Lithium and arsenic anomalies are rare below $838.2 \mathrm{~m}$ and correlate with fault zones. Mercury is present in background concentrations below this depth, perhaps due to instability at high temperatures. Oxygen and carbon stable isotope analyses were obtained for calcite from twenty-six cuttings samples from Wel1 $\mathrm{C} / \mathrm{T}-2$ in an attempt to estimate calcite deposition temperatures and to 10cate contemporary or fossil thermal fluid entries. The analyses are averages for the intervals sampled because the small size of the cuttings and complex alteration paragenesis prevented sampling individual calcite occurrences.

Bulk density, magnetic susceptibility, and thermal conductivity measurements were made on the cuttings samples. Many density measurements appear too high and thermal conductivity measurements appear too low for the rock types penetrated. Both results may be due to concentration of mafic minerals during sample collection and/or washing. The bulk density data demonstrates a correlation between higher densities and more mafic rocks. The magnetic susceptibility values range between 40 and $2000 \mu \mathrm{cgs}$ in the alluvium and between 50 and 6000 ucgs in the crystalline rocks. Although no clear correlation is evident between magnetic susceptibility and lithology, the highest values tend to be associated with more mafic rock types. A further result is that increasing density correlates with increasing magnetic susceptibility.

Caliper, temperature, neutron porosity, bulk density, acoustic velocity and natural gamma well logs were obtained in $C / T-2$. One of each log, except for acoustic velocity, was obtained using Dresser Atlas logging tools. Schlumberger tools were used to obtain a neutron porosity, acoustic velocity and a natural gamma log. The caliper, temperature and velocity tools experienced problems due to the high temperature environment in $\mathrm{C} / \mathrm{T}-2$. The two natural gamma logs correlated quite well but the two neutron porosity logs did not compare except in a' very qualitative way. In addition, various geochemical data/well log data cross plots were constructed. 


\section{INTRODUCTION}

\section{A. Background}

The Earth Science Laboratory (ESL)/University of Utah Research Institute (UURI), on behalf of the LOS Alamos Scientific Laboratory (LASL) has completed a comprehensive study of cuttings and well logs from LASL Well C/T-2 (Utah State Geothermal Well 9-1) in the Roosevelt Hot Springs KGRA, Beaver County, Utah (Fig. 1-1 and 1-2). The study was undertaken as part of LASL's Geothermal Log Interpretation Development Program, the objective of which is the establishment of an effective geothermal logging data base in the United States. In support of this objective, Phillips Petroleum Company has donated the use of Utah State Geothermal Well 9-1 to LASL for calibration and testing of well-logging equipment in the hot, corrosive, geothermal environment. LASL has renamed the Well $C / T-2$.

Well C/T-2 was collared March 3, 1975 and completed Apri1 18, 1975 at a total depth of $2099 \mathrm{~m}(6885 \mathrm{ft})$. The well encountered anomalously high temperatures (maximum $227^{\circ} \mathrm{C}\left[440^{\circ} \mathrm{F}\right]$ at $2099 \mathrm{~m}$ ), but no significant thermal fluid production zones. The well was cased with a $14 \mathrm{~cm}(51 / 2 \mathrm{in.})$ outside diameter, 17 1b, K-55 BT\&C casing to a depth of $1280 \mathrm{~m}$ (4198 ft) below the kelly bushing which was $4.15 \mathrm{~m}(13.6 \mathrm{ft})$ above ground level or permanent datum of $1796.8 \mathrm{~m}$ (5828 ft) above sea level. Cuttings samples and well logs obtained by ESL for Well C/T-2 have been studied by various methods as herein reported. The report is organized by specific tasks outlined in Contract No. 4-N29-4988H-1.

\section{B. Location}

Well $\mathrm{C} / T-2$ is located in the Roosevelt Hot Springs KGRA in Beaver County, Utah. The nearest town is Milford, Utah, which is served by regularly scheduled commuter flights. The nearest rental cars are in Cedar City, which is roughly 50 miles south of Milford. Well C/T-2 can be reached by traveling three miles north of Milford on Highway 257, then turning east onto a graded county road and driving seven miles. The access road to the well turns off to the northeast. The county and access roads are marked with signs that point toward "LASL Well C/T-2". 


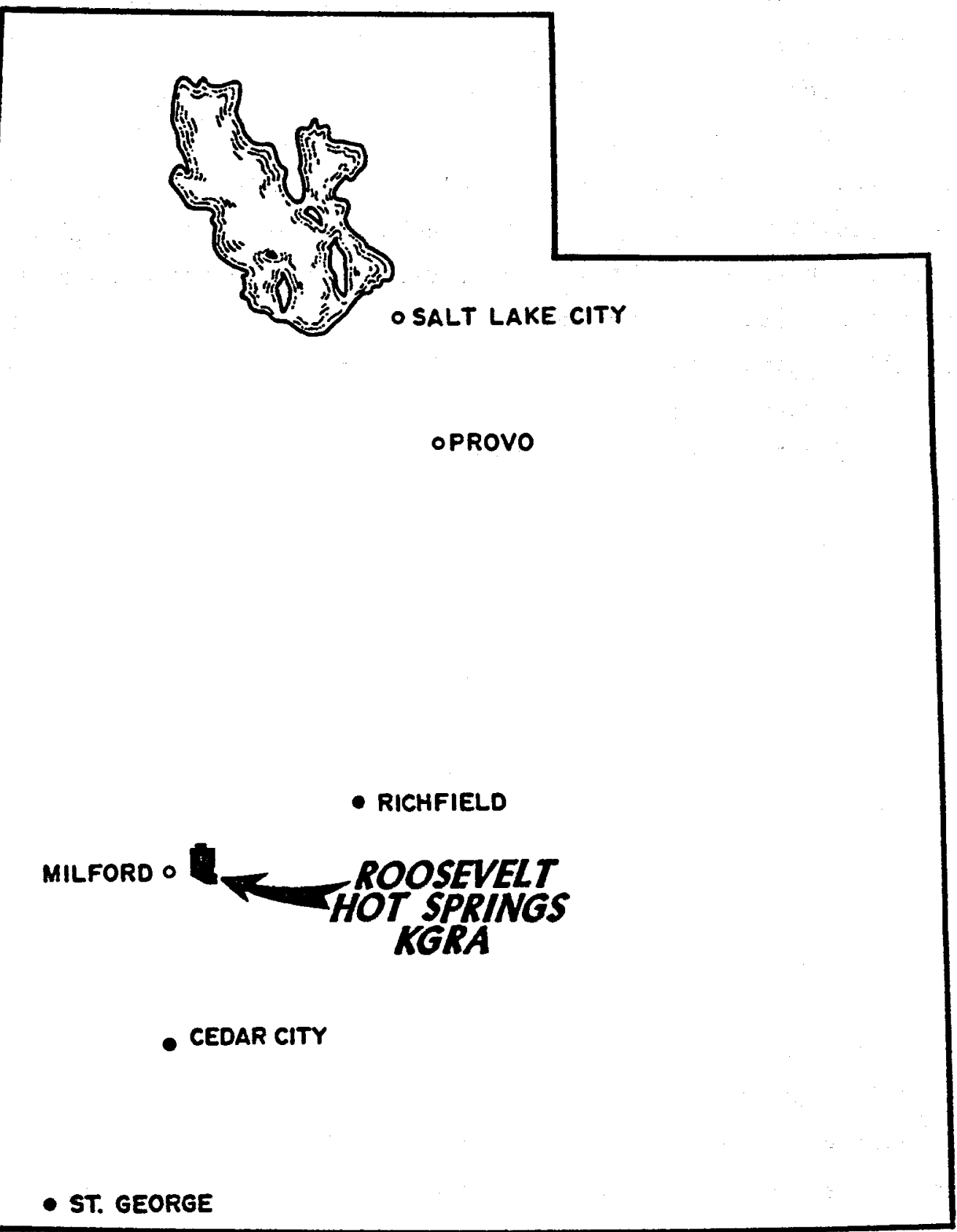

Fig. 1-1. Location map. 


\section{Geology of the Roosevelt Hot Springs KGRA}

The geology of Roosevelt Hot Springs KGRA has been described in detail by Nielson et al. (1978). In addition, a summary of the geology, geochemistry and geophysics has been published by ward et al. (1978). Lithologic logs of available holes can be found in Hulen (1978) and Nielson et al. (1978). An evaluation of well logs from Utah State Geothermal Wells 72-16, 14-2, and 52-21 and temperature gradient hole GPC-15 can be found in Glenn and Hulen (1979a). A more regional picture of the geology of the central Mineral Mountains is presented in Sibbett and Nielson (1980).

The Roosevelt Hot Springs KGRA is located on the western edge of the Mineral Mountains in Beaver County, Utah. Exploration for geothermal resources at Roosevelt Hot Springs was initiated by Phillips Petroleum Company in 1975. The known geothermal resource is owned by Phillips and a joint venture of Thermal Power, AMAX, and 0'Brien Mines. The geology of the currently known producing area is shown in Fig. 1-2, which also shows the location of Well C/T-2 and seven producing test holes in the Roosevelt field. In general, the Roosevelt Hot Springs geothermal system is a hot-water dominated geothermal resource. Fluid temperatures in the producing region are in excess of $265^{\circ} \mathrm{C}\left(509^{\circ} \mathrm{F}\right)$. The geothermal reservoir is structurally controlled, occupying faults and fractures that cut plutonic and high-grade metamorphic rocks.

The lithologies that are present in the area are described in detail in Nielson et al. (1978) and Sibbett and Nielson (1980). The detailed logging of lithologies in Well $\mathrm{C} / \mathrm{T}-2$ will be related to the units observed in the Mineral Mountains.

The structure of Roosevelt Hot Springs KGRA is dominated by three principal fault directions. The oldest of these faults was developed during a period of low-angle normal faulting. This activity has produced zones of cataclastic, silicified rock along the low-angle fault and along high-angle faults in the hanging wall. A second series of faults, trending generally east-west, are high-angle normal faults and are thought to be long-lived structures. The most recent faults in the area are north-south to northeast trending normal faults. These faults are represented in the geothermal area by the Opal Mound Fault (Fig. 1-2), which has controlled the deposition of siliceous sinter in the recent past. 
Explanation for Geologic Map and Cross Soction (FFoures 1.2 and 1.3J

Os Opaline and chalcedonic sinter

Oeal Silica-cemented alluviun

On Hematite-cemented alluvium

Dal Alluvium

Oro Air-fall and non-welded ash-flow tuff

Tds Diabase dikes

Tind Microdiorite dikes

Ter Granite dikes; fine-grained

T. Granite; medium- to coarse-grained

T. Syenite; medium-grained

Tog Blotite granite; medium- to coarse-grained

Tqm Quartz monzonite

To Diorite; fine-to medium-grained

ngn

Biotite granodiorite; fine- to medium-grained

hgn Hornblende gneiss; medium- to coarse-grained

5 Pcoo Banded gneiss; conspicuously layered feldspar-

pcoo quartz-biotite gneiss, schist and migmatite

Contact, dashed where uncertain

Fault, intruded by microdiorite dike; arrow shows dip

To : Fault, dashed where inferred, dotted where concealed;

sorrow shows dip

$\because \nabla^{\Delta} \quad$ Brecciation

Strike and dip of inclined and vertical Joints

of Strike and dip of inclined and vertical foliation

a Prospect

$\phi$ Shallow diamond drill hole

G Geothermal well

From Sibbetf a Nielson, 1980 


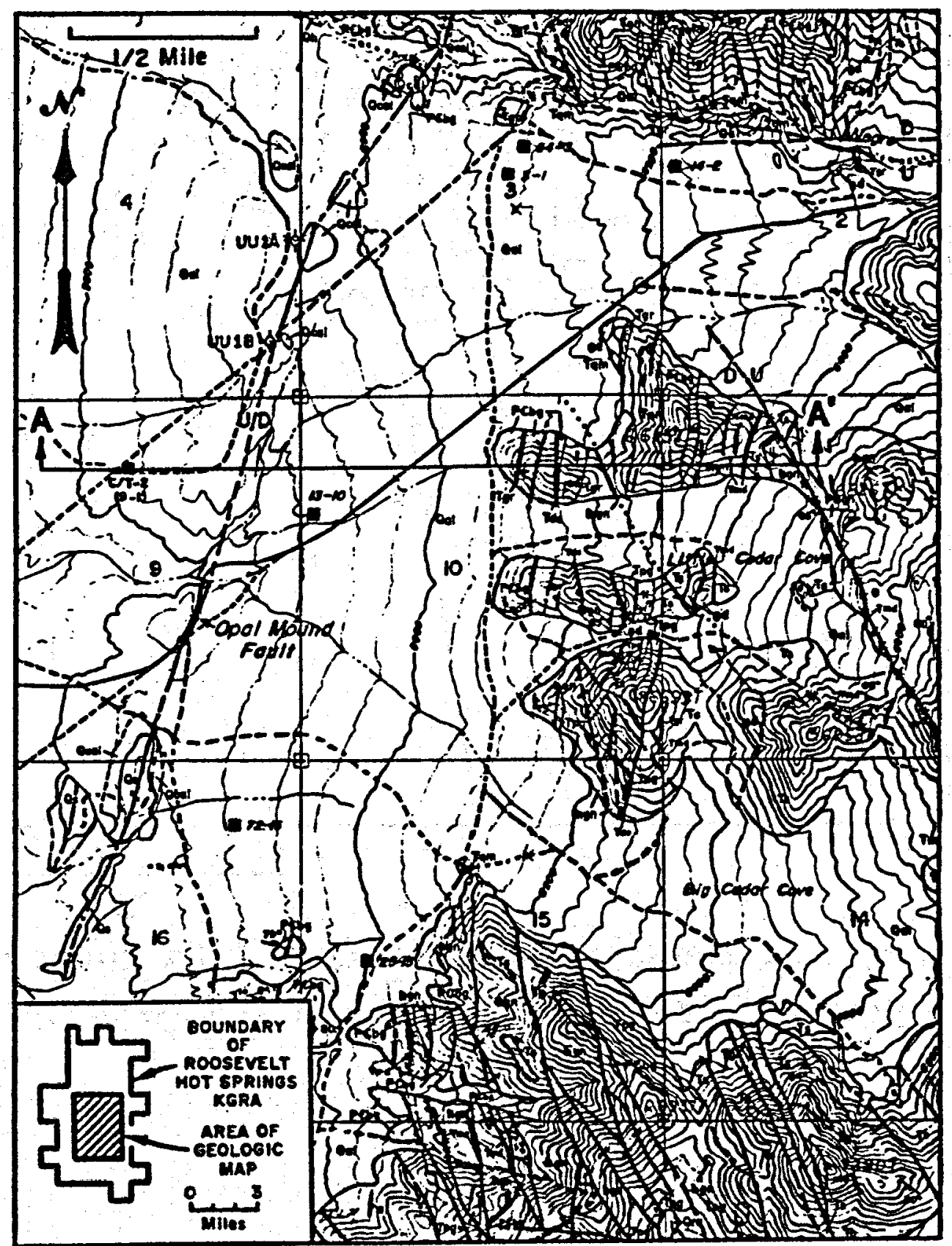

Fig. 1-2. Geologic map . 


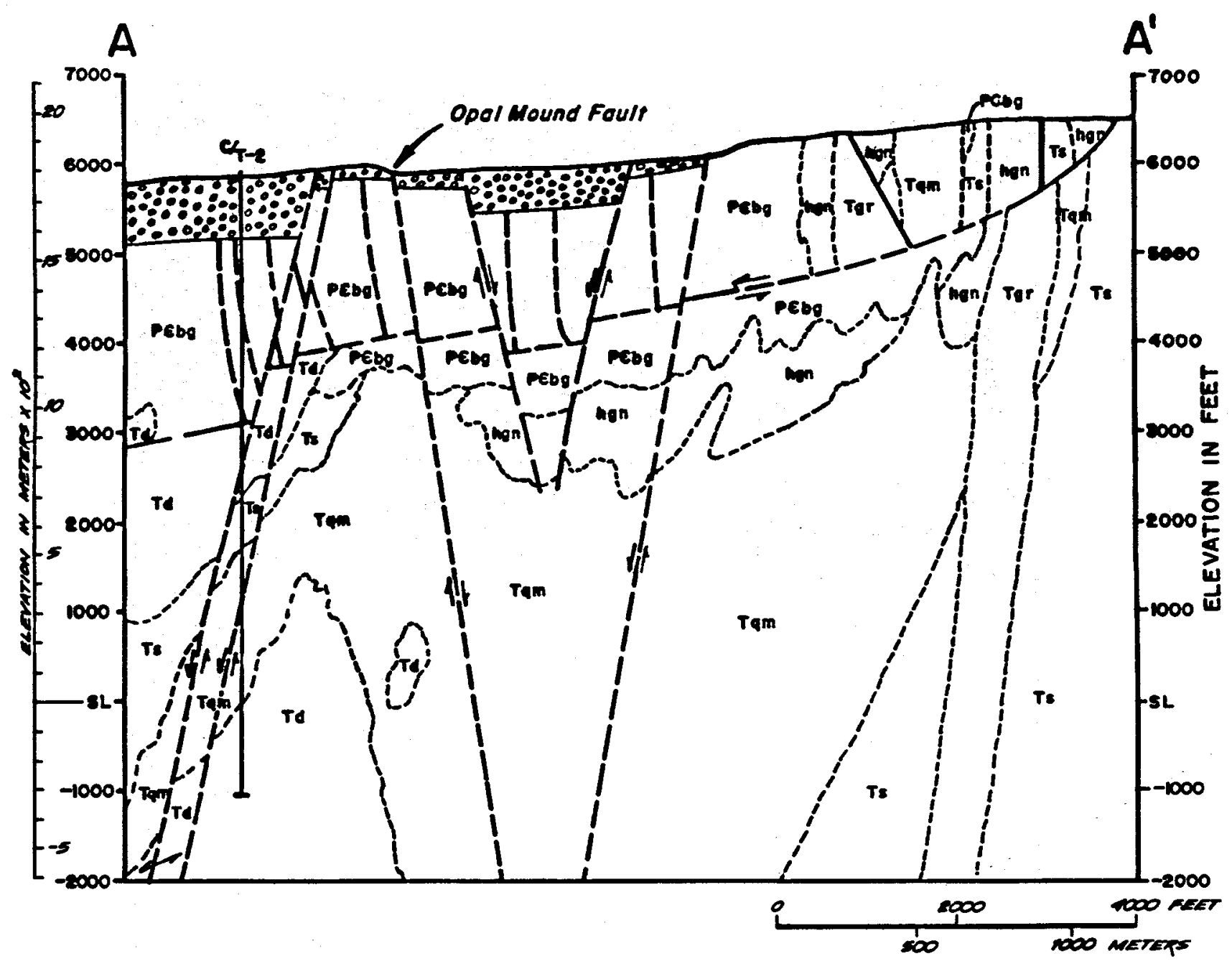

Fig. 1-3. Geologic cross section of the Roosevelt Hot Springs geothermal area showing Well C/T2. 
Niel son et al. (1978) proposed that the geothermal production is controlled by increased permeability developed at the zones of intersection of two or three of these principal fault directions. These zones of intersection are responsible for an upper level reservoir zone and the geothermal fluids have been channeled from depth along steeply dipping faults such as the Opal Mound Fault.

Figure 1-3 is an east-west geologic cross section of the Roosevelt Hot Springs geothermal field through Well C/T-2. Note that the well is located west of a horst that is bounded on the east by the 0pal Mound Fault. A low-angle normal fault passes through the well at about $844.3 \mathrm{~m}(2770 \mathrm{ft})$. The relationships that were mapped on the surface hold true within Well C/T-2: the hanging wall of this fault is extensively brecciated whereas the footwall has been intersected only by an occasional discrete fault. The rocks above $844.3 \mathrm{~m}(2770 \mathrm{ft})$ have been extensively altered by hydrothermal fluids. No significant fluid entries have been reported and the entire well intersects low-permeability rocks and is considered dry.

\section{LITHOLOGIC LOGGING AND ALTERATION STUDIES}

\section{A. Methods and Procedures}

Drill cuttings from Well $\mathrm{C} / \mathrm{T}-2$ were collected by Phillips Petroleum Company generally at $4.6 \mathrm{~m}$ (15 ft) intervals above a depth of $686.8 \mathrm{~m}$ (2250 $\mathrm{ft}$ ), and at $3.1 \mathrm{~m}(10 \mathrm{ft})$ intervals below this depth, to the bottom of the well. These cuttings were thoroughly washed to remove drilling mud and lost-circulation material. Chipboards were prepared from small portions (roughly $1.5 \mathrm{~g}$ ) of the cuttings.

Cuttings from Well C/T-2 were first logged in detail by conventional binocular microscope at 8-40X magnification. Data logged include lithology, style and intensity of alteration and mineralization, and physical evidence of structural disruption, including amounts of fault gouge, microbreccia, and mylonite present in each sample. This lithologic $10 \mathrm{~g}$ is presented in Fig. A (microfiche in pocket of inside back cover).

Petrographic study of selected cuttings samples from well $\mathrm{C} / \mathrm{T}-2$ resulted in more accurate characterization of rock types and alteration phases identified during binocular microscopic examination. Seventy-five grain-mount 
thin sections were examined. Half of each section was stained with sodium cobaltinitrite to aid in identification of potassium feldspar. The sections were prepared from samples collected at roughly $30.5 \mathrm{~m}$ (100 ft) intervals, except where lithologic complexity and/or alteration dictated closer sample spacing. For representative samples apparently consisting wholly or mostly of a single rock type, modes were obtained (Table 2-I) by a combination of visual estimation and abbreviated point count (200-300 points). Such point counts are not adequate for determination of trace and minor mineral percentages, but are believed to be more accurate than visual estimation for determination of major rock-forming mineral quantities.

Alteration mineralogy in Well $\mathrm{C} / \mathrm{T}-2$ was further investigated by $\mathrm{X}$-ray diffraction of clay separates $(<2 \mu)$ from representative cuttings samples. The clay fraction was prepared by pulverizing a $10 \mathrm{~g}$ sample-split in a Spex shatterbox with tungsten carbide components, peptizing the pulverized sample with calgon, and centrifuging. X-ray diffraction patterns were obtained for oriented smears on glass slides following air-drying, and, if appropriate, vapor glycolation and heating to $250^{\circ} \mathrm{C}\left(482^{\circ} \mathrm{F}\right)$ and $550^{\circ} \mathrm{C}\left(1022^{\circ} \mathrm{F}\right)$.

Microprobe analyses of selected alteration and rock-forming minerals were obtained using a three-channel ARL electron microprobe at an acceleration voltage of $15 \mathrm{kV}$. $X$-rays were counted at an average of 5 spots on each grain for approximately $16 \mathrm{~s}$. Clinopyroxene and kaersutite standards were used for most major and minor elements. A biotite standard was used for potassium, a barium oxide glass standard for barium, a fluorphlogopite standard for fluorine, and a scapolite standard for chlorine. Bence-Albee matrix corrections (Bence and Albee, 1968) were then calculated using a computer program developed by G. H. Ballantyne, J. M. Ballantyne, and W. T. Parry, of the University of Utah Department of Geology and Geophysics. Input for this program requires an ideal water content for the mineral analyzed. The initial oxide data are corrected by an iterative routine, which yields successively more accurate approximations of actual bound water content (Ballantyne, J. M., 1978).

Cuttings collected from Well C/T-2 are extremely fine, averaging less than $0.5 \mathrm{~mm}$ in diameter above $899.4 \mathrm{~m}(2950 \mathrm{ft})$ and less than $0.3 \mathrm{~mm}$ in diameter below this depth. The small size of these cuttings may hinder accurate characterization of certain parameters in the well, such as grain 
TABLE 2-I

PETROGRAPHIC SUTYYMRY, SELECTED

SNIPLES FROH HELL C/T-2

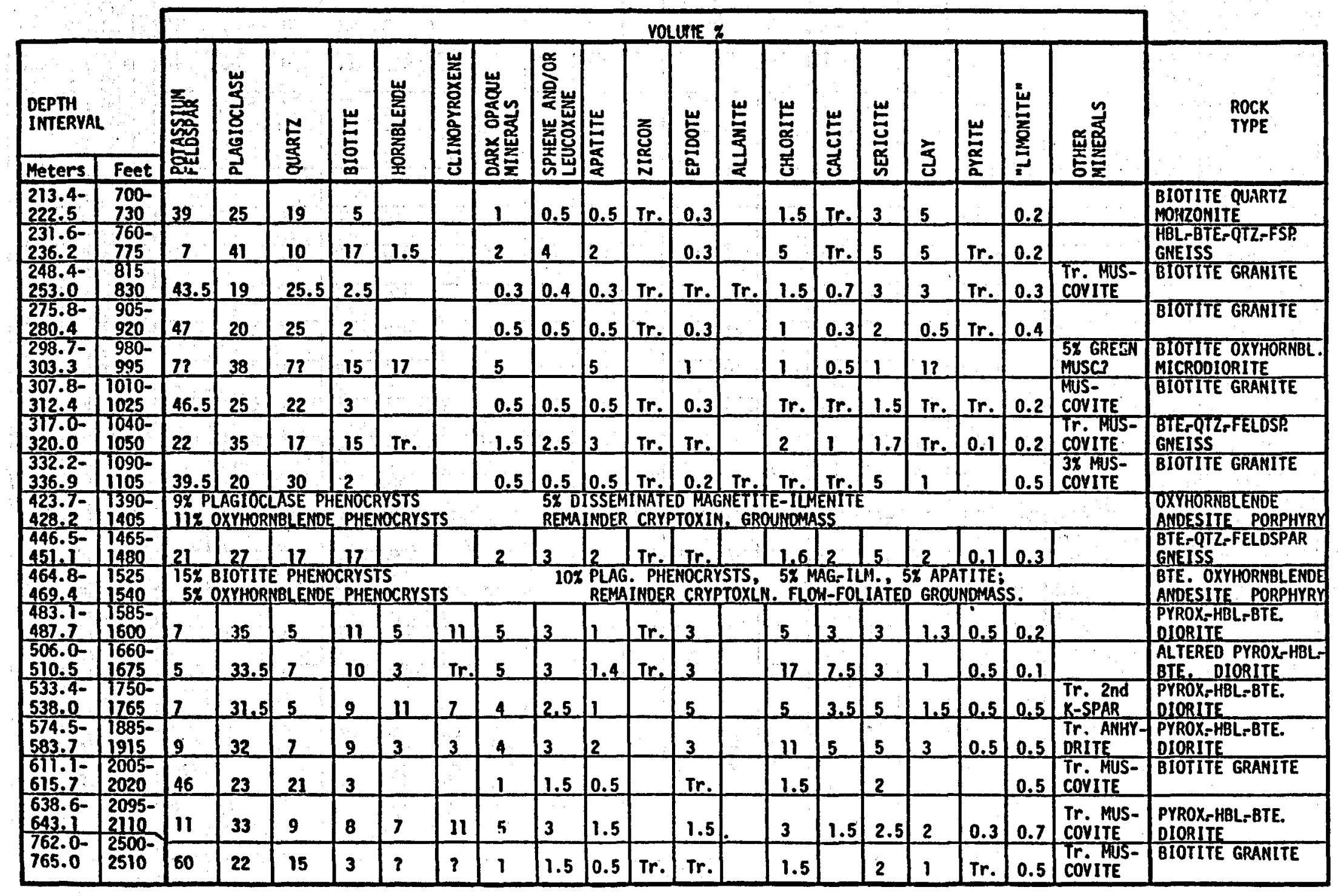


TABLE 2-I (cont.)

\begin{tabular}{|c|c|c|c|c|c|c|c|c|c|c|c|c|c|c|c|c|c|c|c|c|c|}
\hline & & & & & & & & & & & & LUMIE & & & & & & & & & \\
\hline $\begin{array}{l}\text { DEPTH } \\
\text { INTERVA }\end{array}$ & Feet & 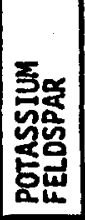 & 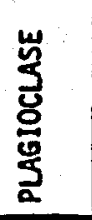 & $\frac{\mathrm{N}}{\mathrm{z}}$ & 苫 & $\begin{array}{l}\text { 愛 } \\
\text { 兽 } \\
\text { 空 }\end{array}$ & 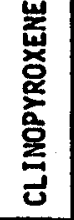 & 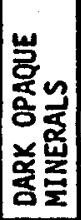 & 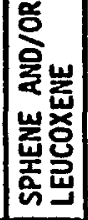 & 岕 & 惹 & 容 & 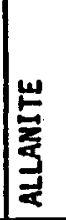 & 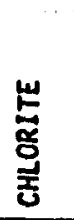 & 岕 & 岂 & ذ্ & 岕 & 岂 & 点䆠岕 & $\begin{array}{l}\text { ROCK } \\
\text { TYPE }\end{array}$ \\
\hline $\begin{array}{l}816.9- \\
819.9\end{array}$ & $\begin{array}{l}2680- \\
2690\end{array}$ & 52 & 20 & 12 & 2.5 & $0.5 ?$ & & 1.5 & 1.5 & 0.4 & 0.1 & Tr. & & 3 & & 3 & Tr. & 0.1 & & & $\begin{array}{l}\text { HORNBLENDE( }(?)- \\
\text { BIOTITE GRANITE }\end{array}$ \\
\hline \begin{tabular}{|l}
$835.2-$ \\
838.2 \\
\end{tabular} & $\begin{array}{l}2740- \\
2750 \\
\end{array}$ & 15 & 15 & 17 & 7 & 1 & 0.5 & 5 & 2.5 & 2 & & $\dot{i r}$. & & 12 & 5 & 12 & 7 & 0.5 & 0.1 & $\begin{array}{l}\text { T7\% MuS- } \\
\text { COVITE }\end{array}$ & $\begin{array}{l}\text { MIXED ROCK TYPES } \\
\text { PLUS MYLOMITE }\end{array}$ \\
\hline $\begin{array}{l}883.9- \\
887.0\end{array}$ & 290 & 19 & 43 & 15 & 13 & 2 & 0.4 & 1.5 & 1.5 & 0.7 & & $T r$. & 0.1 & 2 & 1.3 & 1 & & Tr. & & $\begin{array}{l}\text { Tr. MUSS- } \\
\text { COVITE }\end{array}$ & $\begin{array}{l}\text { PYROX-HBL-BTE. } \\
\text { GRANODIORITE }\end{array}$ \\
\hline $\begin{array}{l}914.4- \\
917.4\end{array}$ & $\begin{array}{l}3000- \\
3010\end{array}$ & 21 & 31 & 15 & 17 & 2.5 & Tr. & 2 & 1.5 & 1.4 & & 1. & 0.1 & 3 & 2 & 2.5 & Tr. & Tr. & & $\begin{array}{l}\text { Tr. WUS- } \\
\text { COVITE }\end{array}$ & $\begin{array}{l}\text { BIOTITE-HBL. } \\
\text { QTZ. MONZONITE }\end{array}$ \\
\hline $\begin{array}{l}1018.0- \\
1021.1\end{array}$ & $\begin{array}{l}3340- \\
3350- \\
\end{array}$ & 21.5 & 30 & 12 & 15 & 4 & 0.5 & 2 & 1.5 & 1 & & 0.4 & 0.1 & 3 & 2 & 1.5 & & Tr. & 0.5 & $\begin{array}{l}\text { Tr. ANHY- } \\
\text { ORITE }\end{array}$ & $\begin{array}{l}\text { PYROX-HBLFBTE. } \\
\text { GRANODIORITE }\end{array}$ \\
\hline $\begin{array}{l}1048.5- \\
1051.6\end{array}$ & $\begin{array}{l}3440- \\
3450\end{array}$ & 7 & 40 & 3 & 9 & 15 & & 5 & 1.3 & $3 ?$ & & 0.4 & & & 1 & 1 & & 0.1 & 0.1 & $\begin{array}{l}7 \text { ACTI- } \\
\text { MOLITE }\end{array}$ & $\begin{array}{l}\text { BIOTITE OXYHORNBL. } \\
\text { MICRODIORITE }\end{array}$ \\
\hline $\begin{array}{l}1094.2- \\
1097.3\end{array}$ & $\begin{array}{l}3590- \\
3600 \\
\end{array}$ & 45 & 27.5 & 13 & 6 & 1 & & 2 & 0.5 & 0.4 & & $T r$. & & 1 & Tr. & 3.5 & Tr. & 0.1 & Tr. & & $\begin{array}{l}\text { HORNBLENDE-BTE. } \\
\text { OUAKTZ MONZONITE }\end{array}$ \\
\hline $\begin{array}{l}1124.7- \\
1127.8\end{array}$ & $\begin{array}{l}3690- \\
3700\end{array}$ & 50 & 24.5 & 11 & 7 & 1 & Tr. & 2 & 0.5 & 0.3 . & & Tr. & 0.2 & 0.5 & Tr. & 8 & & Tr. & & & $\begin{array}{l}\text { HORNBLENDE-BTE. } \\
\text { GRANITE }\end{array}$ \\
\hline $\begin{array}{l}1155.2- \\
1158.2\end{array}$ & $\begin{array}{l}3790- \\
3800\end{array}$ & 55 & 22.5 & 10 & 5 & 1 & & 2 & 0.5 & 0.9 & & Tr. & 0.1 & 1 & Tr. & 2 & & $T r$. & & & $\begin{array}{l}\text { PRORNBLENDE-BTE. } \\
\text { GPANITE }\end{array}$ \\
\hline $\begin{array}{l}1185.7- \\
1188.7\end{array}$ & $\begin{array}{l}3890- \\
3900\end{array}$ & 55 & 25.5 & 9 & 3 & 0.5 & & 2 & 0.5 & 0.5 & & Tr. & rr. & 1 & Tr. & 3 & & Tr. & & & BIOTITE GRANITE \\
\hline $\begin{array}{l}1219.2- \\
1222.2\end{array}$ & $\begin{array}{l}4000- \\
4010 \\
\end{array}$ & 54 & 26 & 11 & 3 & 0.5 & & 2 & 0.5 & 0.5 & & Tr. & & 1.5 & & 2 & & $\mathrm{Tr}$. & & & BIOTITE GRANITE \\
\hline $\begin{array}{l}1246.6- \\
1250.0\end{array}$ & $\begin{array}{l}4090- \\
4100\end{array}$ & 50 & 25 & 12 & 3 & 0.5 & & 2 & 0.5 & 0.5 & & Tr. & Tr. & 2 & 1.5 & 3 & Tr. & Tr. & & & BIOTITE GRANITE \\
\hline $\begin{array}{l}1277.1 \\
1280.2\end{array}$ & $\begin{array}{l}4190- \\
4200\end{array}$ & 35 & 25 & 12 & 15 & 3 & 0.5 & 2 & 1 & 0.5 & & 0.5 & & 3.5 & Tr. & 2 & & Tr. & & & $\begin{array}{l}\text { HBLFBTE. QUARTZ } \\
\text { MONZONITE }\end{array}$ \\
\hline $\begin{array}{l}1313: 7- \\
1316.7\end{array}$ & $\begin{array}{l}7310- \\
4320\end{array}$ & 36 & 27 & 15 & 11 & Tr. & & 2 & 1 & 0.5 & Tr. & Tr. & Tr. & 3.5 & 2 & 2 & & Tr. & & & $\begin{array}{l}\text { HBL.BTE. QUARTZ } \\
\text { MONZONITE }\end{array}$ \\
\hline $\begin{array}{l}1338.1- \\
1341.1-\end{array}$ & $\begin{array}{l}4390- \\
4400\end{array}$ & 36 & 27 & 15 & 12 & 2.5 & Ir. & 2.5 & 0.5 & 0.5 & & Tr. & & 0.5 & 1.5 & 2 & & Tr. & & $\begin{array}{l}\text { Tr. MUS- } \\
\text { COVITE }\end{array}$ & $\begin{array}{l}\text { HBL.BTE. QUARTZ } \\
\text { MONZONITE }\end{array}$ \\
\hline $\begin{array}{l}1368.6- \\
1371.6\end{array}$ & $\begin{array}{l}4490- \\
4500\end{array}$ & 35 & 29.5 & 15 & 12 & 1.5 & & 2 & 1 & 0.5 & & Tr. & & 1.5 & 0.5 & 1.5 & & $\operatorname{Tr}$. & & & $\begin{array}{l}\text { HBL-BTE, QUARTZ } \\
\text { MONZONITE }\end{array}$ \\
\hline $\begin{array}{l}1399.0- \\
1402.1\end{array}$ & $\begin{array}{l}4590- \\
4600\end{array}$ & 35 & 30 & 15 & 12 & 1.5 & Tr. & 2 & 1 & 0.5 & & Tr. & & 1 & 0.5 & 1.5 & & Tr. & & & $\begin{array}{l}\text { HBL.BTE. QUARTZ } \\
\text { MONZONITE }\end{array}$ \\
\hline $\begin{array}{l}1429.7- \\
1432.0\end{array}$ & $\begin{array}{l}4690- \\
4700\end{array}$ & 35 & 29 & 12 & 13 & 2 & & 1.5 & 1.5 & 0.5 & Tr. & $\mathrm{Tr}$. & & 3 & 0.5 & 2 & & Tr. & & & $\begin{array}{l}\text { मBL-BTE. QUARTZ } \\
\text { MONZONITE }\end{array}$ \\
\hline $\begin{array}{l}1450.8- \\
1453.9\end{array}$ & $\begin{array}{l}4760- \\
4770\end{array}$ & 22.5 & $13 ?$ & 30 & 5 & 0.5 & & 2 & $2 ?$ & 0.5 & Tr. & 0.4 & & 7 & 5 & 12 & & 01 & & & $\begin{array}{l}\text { ALTERED BREOCIATED } \\
\text { HBLSBSE. QUARTZ } \\
\text { MONZONITE }\end{array}$ \\
\hline
\end{tabular}

C. 
TABLE 2-1 (cont.)

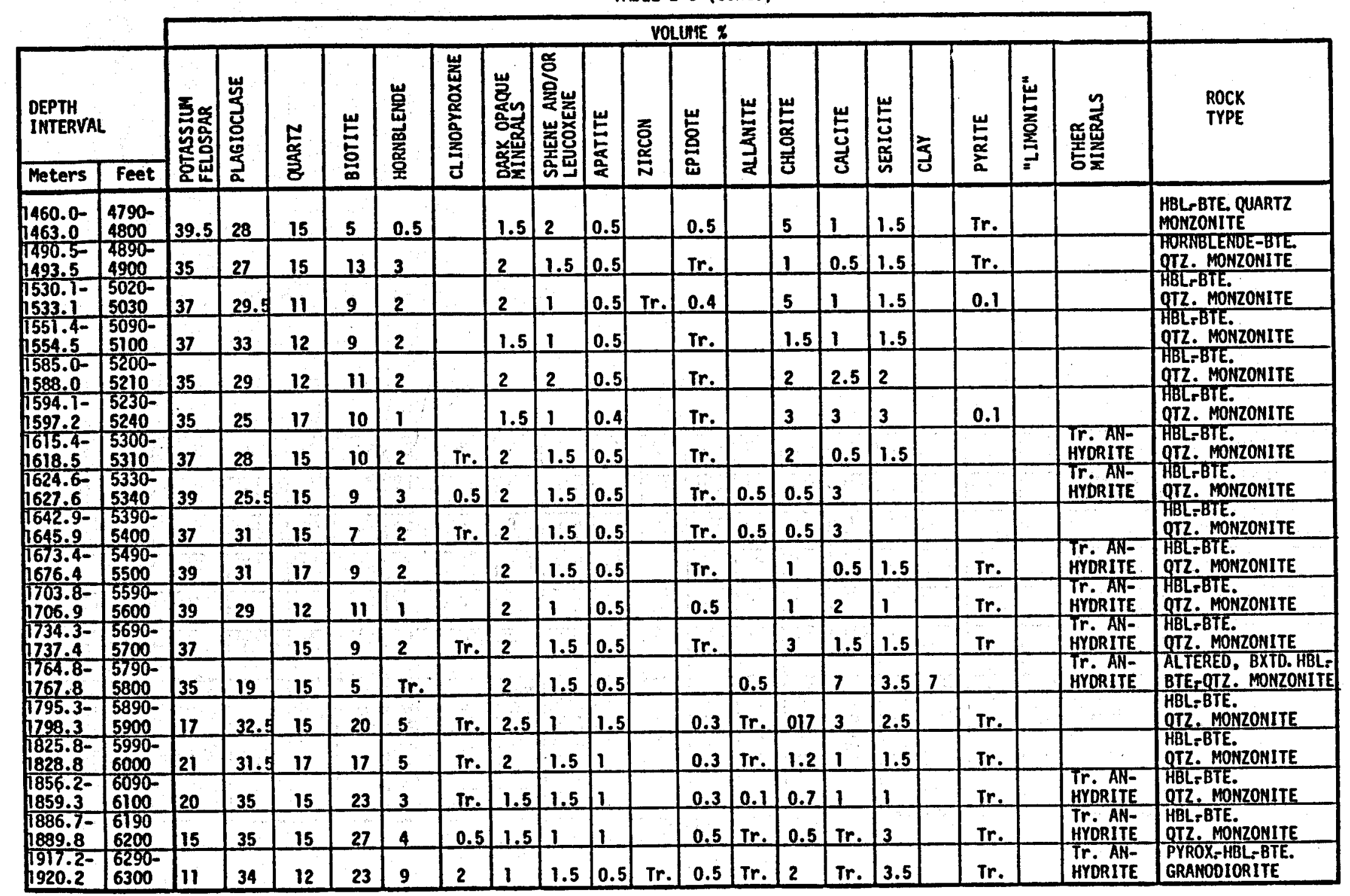


TABLE 2-I (cont.)

\begin{tabular}{|c|c|c|c|c|c|c|c|c|c|c|c|c|c|c|c|c|c|c|c|c|c|}
\hline & & \multicolumn{19}{|c|}{ VOLUAIE $\%$} & \multirow[b]{2}{*}{$\begin{array}{l}\text { ROCK } \\
\text { TYPEE }\end{array}$} \\
\hline \multicolumn{2}{|c|}{$\begin{array}{l}\text { DEPTH } \\
\text { INTERVAL }\end{array}$} & 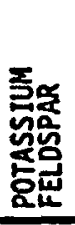 & 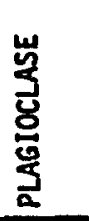 & $\frac{\text { № }}{\frac{3}{8}}$ & 㟢 & 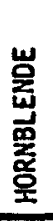 & 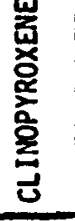 & 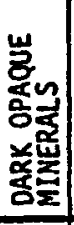 & 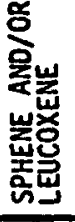 & 峚 & 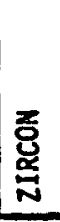 & 岕 & 点 & $\begin{array}{l}\text { 㟧 } \\
\text { 옹 } \\
\text { 콩 }\end{array}$ & 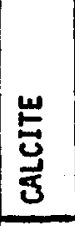 & 嵩 & डे & 冚 & $\begin{array}{l}\text { 岁 } \\
\text { 总 } \\
\text { 惫 } \\
\end{array}$ & 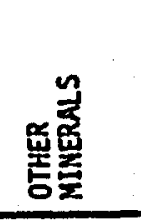 & \\
\hline 1947.7- & $\begin{array}{l}6390- \\
6400 \\
\end{array}$ & 13 & 37.5 & 12 & 25 & 4 & 0.5 & 2 & 1 & 1 & & 0.5 & Ir. & 1 & 1.5 & 1 & & Ir. & & $\begin{array}{l}\text { Tr. AN- } \\
\text { HYORIIE }\end{array}$ & $\begin{array}{l}\text { HBL-BTE. } \\
\text { GRAMODIORITE }\end{array}$ \\
\hline $\begin{array}{l}1978.2- \\
1981.2\end{array}$ & $\begin{array}{l}6490- \\
6500\end{array}$ & 12.5 & 33 & 12 & 33 & 4 & Tr. & 1 & 1 & 1.5 & & 0.4 & 0.1 & Tr. & 0.5 & 0.5 & & & & $\begin{array}{l}0.57 \text { AA- } \\
\text { HYORITE }\end{array}$ & $\begin{array}{l}\text { HBL-BTE. } \\
\text { GRAMODIORITE }\end{array}$ \\
\hline $\begin{array}{l}2008.6- \\
2011.7\end{array}$ & $65900-$ & 15 & 33.5 & 12 & 27 & 3 & Tr: & 1.5 & 1.5 & 1.5 & & 0.3 & Tr. & 1 & 2 & 1.5 & & & & $\begin{array}{l}0.2 \pi \text { AN- } \\
\text { HYORITE }\end{array}$ & $\begin{array}{l}\text { HBL-BTE. } \\
\text { GRANODIORITE }\end{array}$ \\
\hline 2039.1- & 66900 & 13 & 38 & 10 & 23 & 5 & 3 & 3 & 1.4 & 1 & & 0.5 & 0.1 & 1 & $T r$ & 1 & & & & $\cdot$ & $\begin{array}{l}\text { PYROXEME-HBL-BTE. } \\
\text { GRAHODIORITE }\end{array}$ \\
\hline$\frac{1042.2}{2069.6-}$ & $6790-$ & & & & 31 & 4 & $T r$ & ? & 1,5 & 1 & & 0.1 & Tr & 0 & Tr & 10.4 & & & & $\begin{array}{l}0.1 \% \text { AN- } \\
\text { HYDRITE }\end{array}$ & $\begin{array}{l}\text { TBLLPBTE. } \\
\text { GRANODIORITE }\end{array}$ \\
\hline$\frac{2072.6}{2094.0-}$ & $\frac{6800}{6870=}$ & 13 & 34.5 & 12 & 31 & 4 & Ir. & 2 & 1.5 & & & 0.0 & in. & 0.4 & & & & & & Tr. AN- & HBLL-BTE. \\
\hline 209? & 6875 & 15 & 39 & 10 & 25 & 3 & 0.5 & 2.5 & 2 & 1.5 & $T r$. & 0.1 & 0.1 & 0.4 & 0.4 & 0.5 & & & & HYDRITE & GRA \\
\hline
\end{tabular}


size and texture of coarser-grained rocks. Different minerals in a given rock may also have responded differently to fine-grinding at the drill bit in C/T-2. Feldspar and quartz, for instance, would pulverize readily; the original feldspar and quartz in a rock could be powdered and removed from cuttings along with drilling mud during sample collection and washing. This process would yield a cuttings sample richer in biotite (and thus denser) than the rock penetrated.

\section{B. Lithology, Alteration, and Inferred Structure}

A major fault zone between depths of $835.1 \mathrm{~m}(2740 \mathrm{ft})$ and $844.3 \mathrm{~m}$ (2770 $\mathrm{ft}$; Fig. A (inside back cover); Fig. 1-3) divides Well C/T-2 into two distinct structural, lithologic, and alteration regimes. Above this fault zone, lithology is complex, alteration is moderate to locally intense, and evidence of structural disruption is abundant. Below the fault zone, only a few rock types are present, and these are relatively unbroken and only weakly altered:

Lithologic units defined through logging Well $\mathrm{C} / \mathrm{T}-2$ have been tentatively correlated with rock types mapped at the surface and identified in other wells and drill holes within and near the Roosevelt Hot Springs KGRA by Nielson et al. (1978) and Sibbett and Nielson (1980). Correlation was accomplished primarily through comparison of chip samples from Well C/T-2 with representative surface samples crushed, screened, and washed to simulate drill cuttings.

References to grain size and texture of a given rock type in the discussions which follow apply only where drill chip size permits description of these parameters. In general, grain size can be determined with reliability only above a depth of $899.4 \mathrm{~m}(2950 \mathrm{ft})$. Below this depth, drill chips average about $0.3 \mathrm{~mm}$ in diameter, less than the average grain size of most of the rocks. Modes for 61 samples from $C / T-2$ as determined by point counting and visual estimation, are presented in Table 2-I.

1. Lithology. The following rock types encountered in Well C/T-2 and listed below will be discussed in detail in this section: (a) biotite-quartzfeldspar gneiss, (b) biotite-pyroxene-hornblende diorite, (c) hornblendebiotite granodiorite to quartz monzonite, (d) hornblende-biotite-quartz monzonite, (e) hornblende-biotite granite, and (f) microdiorite and andesite. 
a. Biotite-Quartz-Feldspar Gneiss. Several zones of fine- to medium-grained biotite-bearing gneiss were penetrated in C/T-2. This rock type only occurs in significant quantities above the major fault zone centered on $838.2 \mathrm{~m}(2750 \mathrm{ft})$. The gneiss is commonly foliated, even in drill cuttings. Identification of massive gneiss is based upon similarity to coexisting or nearby foliated varieties and upon comparision with surface samples of gneiss crushed to simulate drill cuttings.

Both foliated and massive (in cuttings) gneisses in the drill hole are typically xenomorphic to hypidiomorphic fine- to medium-grained aggregates of quartz, feldspar, biotite and hornblende, in highly variable ratios, with relatively high apatite content, minor sphene and magnetite-ilmenite, and local traces of zircon. Intergrain boundaries, where preserved, are highly irregular, and may show mortar texture. Quartz is generally strained and typically forms irregular aggregates--elongate in foliated varieties--of smaller interlocking irregular grains. Plagioclase $\left(\mathrm{An}_{20}-\mathrm{An}_{30}\right)$ is commonly twinned, occasionally kink-banded, and may show vague gradational normal zoning. Biotite, also locally kink-banded, shows yellow-brown pleochroism and forms irregular grains with ragged terminations that may show subparallel alignment. These biotite grains are often riddled with inclusions of magnetite-ilmenite and/or apatite. Potassium feldspar, commonly with microcline twinning, occurs both as larger grains intergrown with other rock-forming minerals and as minute irregular interstitial grains. Hornblende typically forms rather stubby subhedral crystals, which are pleochroic from medium brownish-green to deep bottle green.

Two varieties of apatite are usually present in the gneiss: (1) larger stubby crystals up to $0.2 \mathrm{~mm}$ in length with $2: 1$ to $4: 1$ length:width ratios and (2) minute acicular needles less than $0.02 \mathrm{~mm}$ in length. The former tend to be concentrated in mafic minerals whereas the latter are concentrated in plagioclase.

Sphene in the gneiss (up to 5\%) forms irregular crystals up to $0.2 \mathrm{~mm}$ in maximum dimension as well as aggregates of these crystals up to $0.7 \mathrm{~mm}$ in maximum dimension. Sphene may also form discontinuous rims around magnetite-ilmenite grains.

Variation in composition, grain size, and foliation of the gneisses in $\mathrm{C} / \mathrm{T}-2$ causes them to resemble other rock types. Felsic varieties may resemble 
granitic intrusives. Mafic gneisses, if sufficiently fine-crystalline, may look like Tertiary microdiorite dikes. For example, between $826 \mathrm{~m}(2710 \mathrm{ft})$ and $835.1 \mathrm{~m}(2740 \mathrm{ft})$, a dense, dark greenish-gray rock originally identified as microdiorite was identified in thin section as a very fine-grained gneiss.

The gneisses in C/T-2 occur with coarser-grained granitic material. This granitic rock represents either felsic segregations, original compositional variations, or intrusions into the gneiss.

Comparison of the gneisses in C/T-2 with surface rock types described by Nielson et al. (1978) and Sibbett and Nielson (1980) strongly suggests correlation with the Precambrian banded gneiss (Nielson et al., 1978, p. 8 ), the oldest rock exposed within the Roosevelt Hot Springs KGRA. In thin section, the granitic rocks associated with gneiss above $798.5 \mathrm{~m}(2620 \mathrm{ft})$ in $\mathrm{C} / \mathrm{T}-2(213.3-222.5 \mathrm{~m}[700-730 \mathrm{ft}], 276.8-280.4 \mathrm{~m}$ [905-920 ft], 307.8-312.4 m [1010-1025 ft], 317.3-320 $\mathrm{m}[1040-1050 \mathrm{ft}], 332.2-336.8 \mathrm{~m}[1019-1105 \mathrm{ft}])$ are observed to range in composition from granite to quartz monzonite. They are xenomorphic to hypidiomorphic-granular aggregates of quartz, potassium feldspar, plagioclase, and minor biotite with accessory apatite, magnetite-ilmenite, and sphene and traces of zircon. An absence of hornblende and a relatively high quartz content, together with local foliation and development of strong undulatory extinction in quartz, distinguish these granitic rocks from others in the hole.

\section{b. Biotite-Pyroxene-Hornblende Diorite. A very distinctive} pyroxene-bearing diorite was penetrated in Well $\mathrm{C} / \mathrm{T}-2$ in scattered intervals between $483.1 \mathrm{~m}(1585 \mathrm{ft})$ and the major fault zone at $844.3 \mathrm{~m}(2770 \mathrm{ft})$. With the exception of cataclasite, to be discussed in section II-B-2 of this report, the diorite is the most pervasively and strongly altered rock type encountered in the drill hole. Alteration comonly obscures the original mineralogy and texture, so that the diorite may be mistaken for the mafic-rich gneiss with which it commonly occurs. The latter, however, is devoid of pyroxene, relatively impoverished in hornblende and magnetite-ilmenite, and enriched in biotite and quartz. The diorite is also invariably massive and equigranular, whereas the gneiss is commonly well-foliated. 
The diorite has no reported surface equivalent at Roosevelt. Of rock types mapped within and near the KGRA, only the hornblende gneiss (hgn), biotite granodiorite ( $g d$ ), and biotite diorite (Td) (Sibbett and Nielson, 1980; Nielson, et al., 1978) are even vaguely similar to the diorite in C/T-2. Except for Tertiary microdiorite, the hornblende gneiss (hgn) and biotite diorite (Td) are the only surface rock types reported to contain pyroxene, but in much lower amounts (tr.-1\%) than the diorite in $\mathrm{C} / \mathrm{T}-2$ (up to 13\%). The diorite in the well is also much richer in total mafic minerals. The biotite grandiorite (gd) is mafic-rich, but with no reported pyroxene. Nielson et al. (1978), however, describe this rock as "highly variable." Possibly the diorite of $\mathrm{C} / \mathrm{T}-2$, with its high mafic content and lack of schistosity, may be a pyroxene-rich variant of either the biotite diorite (Td) or biotite granodiorite (gd).

In thin section, the diorite appears as a fine-grained equigranular aggregate of plagioclase, hornblende, biotite, and clinopyroxene with minor quartz, K-feldspar, magnetite-ilmenite, and sphene, and traces of apatite and zircon. The rock typically shows a distinctive, well-developed mosaic fabric, but may also be xenomorphic- to hypidiomorphic-granular.

Plagioclase $\left(\mathrm{An}_{32-36}\right)$, averaging about 30 vol\% of the diorite, typically occurs as equant to slightly elongate grains, up to $1 \mathrm{~mm}$ in diameter or length, which are very commonly twinned. The twinning is seldom parallel to grain boundaries and is often kink-banded. The plagioclase is invariably partially altered to various combinations of sericite, calcite, epidote, and clay.

The three mafic components of the diorite--biotite, hornblende, and clinopyroxene--occur in highly variable ratios, depending largely on the extent to which pyroxene is replaced by hornblende and biotite, and hornblende is replaced by biotite. All three minerals, which may reach at least $1 \mathrm{~mm}$ in maximum dimension, tend to be equant and irregular, or partially irregular and partially bound by straight margins not related to cleavage traces or crystallographic axes. Microprobe analyses of pyroxene, hornblende and biotite from the diorite at 483.1-487.7 $\mathrm{m}$ (1585-1600 ft) are listed in Table 2-II. The pyroxene is colorless to very slightly brownish-tinged. In addition to being partially altered to hornblende and/or biotite, the pyroxene is also very commonly replaced by subsequent reticulating epidote ( ${ }^{ \pm}$chlorite) 
TABLE 2-II

MICROPROBE CHEMICAL ANALYSES OF

SELECTED ROCK-FORMING AND ALTERATION

MINERALS FROM WELL C/T-2

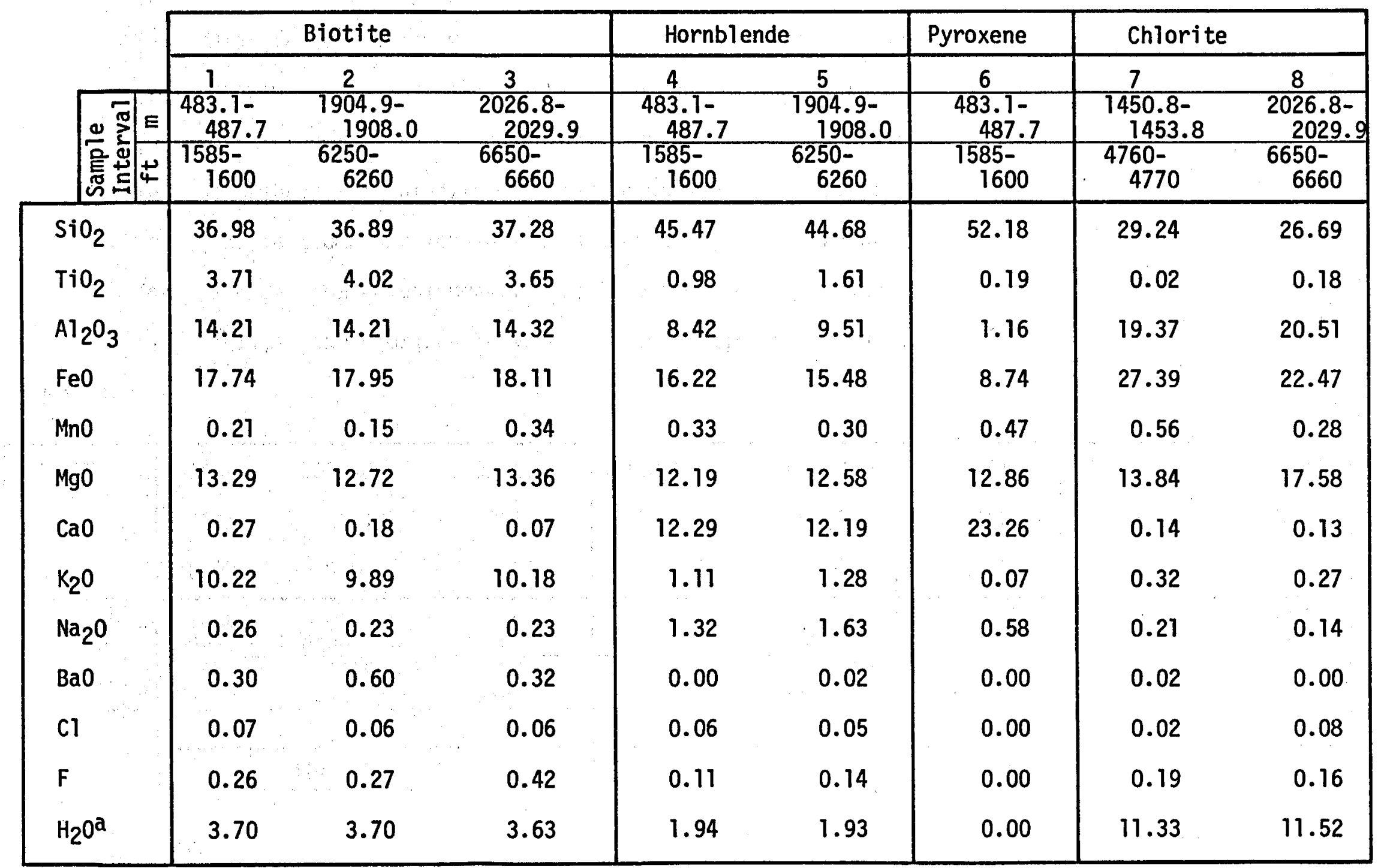


TABLE 2-II (cont.)

\begin{tabular}{|c|c|c|c|c|c|c|c|c|c|}
\hline & & \multicolumn{3}{|c|}{ Biotite } & \multicolumn{2}{|c|}{ Hornblende } & \multirow{2}{*}{$\frac{\text { Pyroxene }}{6}$} & \multicolumn{2}{|c|}{ Chlorite } \\
\hline & & 1 & 2 & 3 & 4 & 5 & & 7 & 8 \\
\hline \multirow{2}{*}{ 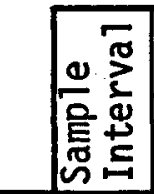 } & $\mathbf{E}$ & $\begin{array}{r}483.1- \\
487.7\end{array}$ & $\begin{array}{r}1904.9- \\
1908.0\end{array}$ & $\begin{array}{r}2026.8- \\
2029.9\end{array}$ & $\begin{array}{r}483.1- \\
487.7\end{array}$ & $\begin{array}{r}1904.9- \\
1908.0\end{array}$ & $\begin{array}{r}483.7- \\
487.7\end{array}$ & $\begin{array}{r}1450.8- \\
1453.8\end{array}$ & $\begin{array}{r}2026.8- \\
2029.9\end{array}$ \\
\hline & $\ddot{+}$ & $\begin{array}{r}1585- \\
1600 \\
\end{array}$ & $\begin{array}{r}6250- \\
6260 \\
\end{array}$ & $\begin{array}{c}6650- \\
6660 \\
\end{array}$ & $\begin{array}{r}1585- \\
1600 \\
\end{array}$ & $\begin{array}{c}6250- \\
6260\end{array}$ & $\begin{array}{r}1585- \\
1600\end{array}$ & $\begin{array}{c}4760- \\
4770\end{array}$ & $\begin{array}{c}6650- \\
6660\end{array}$ \\
\hline $0 \equiv \mathrm{Cl}$ & & 0.02 & 0.01 & 0.01 & 0.01 & 0.01 & 0.00 & 0.01 & 0.02 \\
\hline $0 \equiv F$ & & 0.11 & 0.11 & 0.18 & 0.05 & 0.06 & 0.00 & 0.08 & 0.07 \\
\hline TOTAL & & 101.09 & 100.75 & 101.78 & 100.38 & 101.39 & 99.51 & 102.56 & 99.92 \\
\hline
\end{tabular}

NOTES:

(1) Biotite from biotite-pyroxene-hornblende diorite: 5 grains

(2) Biotite from hornblende-biotite granodiorite: 5 grains

(3) Biotite from hornblende-biotite granodiorite: 5 grains

(4) Hornblende from biotite-pyroxene-hornblende diorite: 5 grains

(5) Hornblende from hornblende-biotite granodiorite: 5 grains

(6) Pyroxene from biotite-pyroxene-hornblende diorite: 7 grains

(7) Chlorite intergrown with sericite in cataclasite: 2 grains

(8) Chlorite replacing biotite in hornblende-biotite granodiorite: 2 grains

a calculated $\mathrm{H}_{2} \mathrm{O}$ 
veinlets, which may occupy up to $50 \%$ of the original crystal volume. Hornblende is strongly pleochroic, from light brown or light brownish to yellowish-green to deep green or brownish-green. Biotite is also pleochroic, from light yellowish-brown to dark brown or greenish-brown. Alteration products of hornblende include biotite (earliest) and epidote, calcite, and chlorite in various combinations. Biotite is partially altered to chlorite, which may be accompanied by sagenitic rutile.

The diorite is relatively rich in magnetite-ilmenite (up to 5\%) and sphene (3-4\%). Magnetite-ilmenite forms irregular to subhedral grains up to $0.3 \mathrm{~mm}$ in diameter, which are invariably intergrown with and commonly rimmed by sphene. Sphene-magnetite-ilmenite intergrowths may reach $1 \mathrm{~mm}$ in maximum dimension. Individual crystals of sphene are generally texturally similar to those of magnetite-ilmenite, although a few scattered sphene crystals are euhedral and reach $0.7 \mathrm{~mm}$ in length (contamination?).

Quartz and K-feldspar in the diorite are commonly highly strained. $\mathrm{K}$-feldspar is otherwise texturally similar to plagioclase. Quartz occurs as individual irregular grains up to $1 \mathrm{~mm}$ in diameter or as aggregates of the same size formed of smaller irregular grains as small as $0.05 \mathrm{~mm}$ in diameter. Quartz is unaltered: K-feldspar may be lightly dusted with clay.

c. Hornblende-Biotite Granodiorite to Quartz Monzonite. ${ }^{1}$ Between 838.2 $\mathrm{m}(2750 \mathrm{ft})$ and $1082 \mathrm{~m}(3550 \mathrm{ft})$ and between $1776.9 \mathrm{~m}(5830 \mathrm{ft})$ and $2095.4 \mathrm{~m}$ $(6875 \mathrm{ft}$ ), Well C/T-2 encountered mafic-rich, possibly weakly metamorphosed intrusives varying in composition from granodiorite through plagioclase-rich quartz monzonite. The upper interval is generally impoverished in mafic minerals relative to the lower interval, but is otherwise very similar and almost certainly part of the same intrusive sequence. Drill chips throughout most of the two intervals are too small for accurate characterization of the grain size and texture of the rock. A few larger chips indicate that the upper interval is medium-grained and the lower interval fine- to medium-grained, with both intervals hypidiomorphic-granular.

1 For convenience of reference, this rock type will be referred to in the text as granodiorite. 
The upper contact of the upper granodiorite interval is apparently in fault contact with broken and altered gneiss between $838.2 \mathrm{~m}(2750 \mathrm{ft})$ and $844.3 \mathrm{~m}(2770 \mathrm{ft})$. The lower contact of this interval seems to be gradational between $1072.82 \mathrm{~m}(3520 \mathrm{ft})$ and $1082 \mathrm{~m}(3550 \mathrm{ft})$. The three $3.1 \mathrm{~m}(10 \mathrm{ft})$ intervals above $1082 \mathrm{~m}(3550 \mathrm{ft})$, contain about $20 \%$ granite each. The upper contact of the lower interval is sharp and may be fault-controlled.

The granodiorite encountered in C/T-2 correlates most readily with the biotite diorite mapped by Sibbett and Nielson (1980) in the northern Mineral Mountains. Samples of the diorite studied to date, however, are devoid of allanite, which is ubiquitous in the granodiorite of the drill hole. The granodiorite is also richer in clinopyroxene, which is present only in trace amounts in the diorite. The granodiorite also closely resembles the biotite granodiorite (Sibbett and Nielson, 1980), which is, however, apparently devoid of clinopyroxene.

Plagioclase (av 33\% by vol) in the granodiorite ranges in composition from $\mathrm{An}_{30}$ to $\mathrm{An}_{35^{\circ}}$. It occurs as anhedral to subhedral grains, up to $0.5 \mathrm{~mm}$ in maximum dimension, as very rare myrmekitic intergrowths with quartz, and as exsolution blebs in perthite. It is invariably partially altered to one or more of the minerals sericite, epidote, and calcite. Potassium feldspar (av 15\%) in the granodiorite is essentially unaltered and is texturally similar to coexisting plagioclase.

Quartz accounts for an average $12 \%$ of the granodiorite. It occurs as lightly strained to unstrained anhedral grains and grain aggregates up to 0.3 mom in diameter.

Biotite (av 25\%) is the dominant mafic constituent in the granodiorite. It is pleochroic from medium yellowish, greenish, or orange-brown to deeper values of the same hues. It occurs as subhedral to euhedral crystals up to $0.5 \mathrm{~mm}$ in diameter or length, and may contain local traces of magnetite-ilmenite and apatite. A few crystals in both the upper and lower granodiorite intervals are sharply kink-banded. The biotite is generally partially altered to chlorite with very low first order or anomalous blue, red, and yellow-brown interference colors. Microprobe analyses of unaltered biotite from 1904-1908 $\mathrm{m}(6250-6260 \mathrm{ft})$ and 2026-2029 $\mathrm{m}(6650-6660 \mathrm{ft})$ are listed in Table 2-II. 
Hornblende averages about $4.5 \%$ of the rock, but ranges from 1.5 to $9 \%$. Subhedral crystals and fragments of hornblende, commonly enclosing small crystals of apatite and dark opaque minerals, reach $0.7 \mathrm{~mm}$ in maximum dimension. The hornblende is pleochroic from medium, slightly brownish to yellowish-green, to deeper values of the same hues or intense deep bottle green. Table 2-II provides a microprobe analysis of hornblende from 1904.9-1908 $\mathrm{m}(6250-6260 \mathrm{ft})$. The hornblende commonly partially replaces clinopyroxene, and is in turn partially replaced, generally along cleavage planes, by biotite. It may also be replaced by various combinations of chlorite, calcite, and epidote. The chlorite replacing hornblende is a different variety from that forming after biotite: it is yellowish- to brownish-green with substantially higher birefringence.

Traces of clinopyroxene occur in almost all samples of the granodiorite. The clinopyroxene locally accounts for $2 \%$ of the total rock volume. Subhedral crystals of the clinopyroxene tend to be stubby or equant, and apparently do not exceed $0.3 \mathrm{~mm}$ in maximum dimension. They are colorless to very slightly brownish- to bluish-green, and are almost always partially replaced by hornblende and, to a lesser extent, by biotite, epidote, calcite, and chlorite.

Magnetite-ilmenite (av 2\%), sphene (av 1.5\%) and apatite (av 1\%) in the granodiorite are texturally very similar to their occurrence in the mafic-rich diorite discussed previously. Sphene in the granodiorite, in particular, shows a strong tendency to form small rims around magnetite-i1menite grains: Apatite may form larger euhedral crystals than in the diorite--up to $0.4 \times 0.2 \times 0.1 \mathrm{~mm}$.

The presence of allanite in all samples of the granodiorite examined distinguishes this rock type from all others in Well $\mathrm{C} / \mathrm{T}-2$. The allanite occurs in anhedral, generally equant crystals and crystal fragments up to 0.05 $\mathrm{mm}$ in diameter, but usually less than $0.01 \mathrm{~mm}$ in diameter, which may rarely form irregular aggregates up to $0.3 \mathrm{~mm}$ in diameter. The mineral may be intergrown with, or, more rarely, rimmed by colorless to pistachiocolored epidote.

Local traces of zircon and rutile are present in the granodiorite. Zircon is texturally similar to its occurrence in the previously discussed diorite higher in the well. The rutile is secondary, occurring with chlorite 
as an alteration product of biotite, and occurs as sagenitically arranged acicular crystals less than $0.05 \mathrm{~mm}$ in length.

d. Hornblende-Biotite Quartz Monzonite. Between $1249.6 \mathrm{~m}(4100 \mathrm{ft})$ and $1776.9 \mathrm{~m}(5830 \mathrm{ft})$, Well $\mathrm{C} / \mathrm{T}-2$ penetrated hornblende biotite quartz monzonite. Drill cuttings from this interval average about $0.5 \mathrm{~mm}$ in diameter and do not exceed $1.5 \mathrm{~mm}$, so grain size and texture of the rock cannot be accurately determined. Larger chips, however, indicate the rock to be hypidiomorphic-granular and at least medium-grained.

The quartz monzonite is uniform in composition except where modified by hydrothermal alteration. Its upper contact with hornblende-biotite granite is gradational; its lower contact with mafic-rich granodiorite is sharp and may be fault-controlled.

Comparison of the quartz monzonite with surface rock types mapped by Nielson et al. (1978) and Sibbett and Nielson (1980) suggests that it most closely correlates with their Tertiary quartz monzonite (Tqm). Drill chips of the quartz monzonite in $\mathrm{C} / \mathrm{T}-2$, however may contain scattered local traces of pyroxene. Average biotite content in the quartz monzonite of the drill hole (10\%) is somewhat higher than that of Tqm (4\%) (Nielson, et al., 1978, Table 3 ). The higher biotite content probably reflects proximity to, and possible assimilation of, mafic-rich units such as the granodiorite in the lower portion of $\mathrm{C} / \mathrm{T}-2$.

Plagioclase forms $23-30 \%$ of the quartz monzonite in the drill hole and averages about $27 \%$. It occurs as: (1) anhedral to subhedral, commonly twinned grains averaging at least $1 \mathrm{~mm}$ in diameter, (2) irregular to subhedral, optically continuous patches, rods and spindles in perthite, and (3) rare myrmekitic intergrowths with quartz. Twin lamellae in the plagioclase are undeformed. The plagioclase is invariably partially replaced by one or more of the minerals sericite, calcite, clay, and epidote.

Potassium feldspar, texturally similar to coexisting plagioclase, accounts for $35-40 \%$ (av 37\%) of the quartz monzonite. Both perthitic and non-perthitic varieties are present. The mineral is generally fresh, but a few crystals may contain a little sericite and/or calcite, which may actually be replacing cryptocrystalline patches of included plagioclase. 
Quartz, mildly strained and nearly free of inclusions, forms an average $13 \%(11-17 \%)$ of the quartz monzonite. It occurs as individual anhedral crystals up to $0.5 \mathrm{~mm}$ in diameter and as minute irregular grains as small as $0.05 \mathrm{~mm}$ in diameter forming equally irregular aggregates up to $0.7 \mathrm{~mm}$ in diameter. In larger drill chips, these aggregates are seen to occur interstially to the other main rock-forming minerals. Quartz also occurs as wormy intergrowths with plagioclase (myrmekite) and with hornblende.

Biotite, pleochroic from yellowish- or reddish-brown to deeper values of the same hues, accounts for 5-17\% (av 10\%) of the quartz monzonite. It occurs primarily as subhedral to euhedral crystals up to $0.7 \mathrm{~mm}$ in length or diameter, but also locally as small patches partially replacing original hornblende. Rare wormy intergrowths of biotite and quartz may represent total replacement of similarly textured hornblende-quartz intergrowths. Biotite commonly contains small inclusions of euhedral apatite and anhedral magnetite-ilmenite. It is rarely intergrown with apatite, sphene, and magnetite-ilmenite in irregular aggregates up to $0.7 \mathrm{~mm}$ in diameter. A portion of the biotite in all samples of the quartz monzonite is partially replaced by pleochroic green chlorite, locally accompanied by sagenitic rutile.

Hornblende (av 1.5\%) in the quartz monzonite is also pleochroic from slightly yellowish- or brownish-green to medium to deep bottle green. Its main occurrence is as subhedral to euhedral crystals with maximum dimensions of $0.7 \times 0.3 \times 0.2 \mathrm{~mm}$. A few hornblende grains throughout the quartz monzonite are riddled with wormy stringers and blebs of quartz. Many crystals contain small inclusions of apatite and dark opaque minerals. Throughout the quartz monzonite, but especially near probable fault zones, the hornblende is partially to completely replaced by various combinations of chlorite, epidote, and calcite.

Magnetite-ilmenite (av 2\%), sphene (av 1.5\%) and apatite (av 0.5\%) are the dominant accessory minerals in the quartz monzonite. Magnetite-ilmenite occurs primarily as anhedral-subhedral equant grains up to $0.2 \mathrm{~m}$ in diameter and as inclusions less than $0.05 \mathrm{~mm}$ in diameter in mafic minerals. It is commonly partially to completely replaced by red-to-maroon submetallic hematite. Sphene, usually partially replaced by leucoxene, forms subhedral grains up to $0.5 \mathrm{~mm}$ in maximum dimension. Apatite typically occurs as 
euhedral prisms, up to $0.04 \times 0.15 \mathrm{~mm}$ in diameter, most commonly embedded in biotite but also in hornblende and plagioclase. Various combinations of these accessory minerals, commonly together with biotite and/or hornblende, form local irregular intergrowths up to $0.7 \mathrm{~mm}$ in diameter.

Zircon and rutile are present in the quartz monzonite in local traces. Zircon occurs as euhedral prisms measuring less than $0.05 \times 0.02 \mathrm{~mm}$ and rutile occurs as sagenitic needles measuring up to $0.1 \times<0.01 \mathrm{~mm}$ in chlorite replacing biotite.

Clinopyroxene in the quartz monzonite is very rare, and may owe its presence to caving. It is very light, slightly brownish- to bluish-green to colorless, nonpleochroic, and is identical to clinopyroxene occurring higher in the drill hole. It is commonly replaced by hornblende and/or biotite, and by chlorite, epidote, and calcite.

Alteration of the quartz monzonite and other rock types will be fully discussed in section II-B-2 of this report.

e. Hornblende-Biotite Granite. A distinctive quartz-poor granite was intersected in C/T-2 between $798.5 \mathrm{~m}(2620 \mathrm{ft})$ and $826.0 \mathrm{~m}(2710 \mathrm{ft})$ and in a major interval between $1082.0 \mathrm{~m}(3550 \mathrm{ft})$ and $1249.6 \mathrm{~m}(4100 \mathrm{ft})$. Larger drill chips indicate this granite to be medium-grained and hypidiomorphic granular. The rock is distinguished from granitic material associated with gneiss above $798.5 \mathrm{~m}(2620 \mathrm{ft})$ by its relatively low quartz content and by the ubiquitous presence of small amounts of hornblende. Among surface rocks mapped at Roosevelt, Tertiary syenite (Nielson, et al., 1978, p. 26, Table V) correlates most closely with the granite in C/T-2. The syenite, however, is even more impoverished in quartz, contains abundant microcline, which is not present in the granite, and is generally richer in mafic minerals and sphene.

Potassium feldspar (av. 52\%), plagioclase (av. 23\%) and quartz (av. 11\%) occur in the granite both as discrete crystals and as various types of intergrowths. Plagioclase and quartz in the granite commonly form myrmekite. Graphic intergrowths of potassium feldspar and quartz are rare. Quartz in the granite typically forms irregular aggregates of equally irregular interlocking grains, some of which are mildly to moderately strained.

Biotite, hornblende, sphene, magnetite-ilmenite and apatite also occur in the granite either as individual grains or in various combinations as 
irregular grain aggregates. Zircon is present in local traces. Biotite (2-5\%) crystals are subhedral, pleochroic from light to dark orange-brown, and up to $1 \mathrm{~mm}$ in length or diameter. Subhedral hornblende ( $\mathrm{Tr}-1 \%)$ is also pleochroic, in various shades of brownish-green, and measures up to $1 \times 0.5 \mathrm{~mm}$ in longitudinal section. Sphene $(0.5-1 \%)$ is honey yellow and anhedral to subhedral in crystals up to $0.3 \mathrm{~mm}$ in length or diameter. Magnetite-ilmenite (1.5-2\%) forms disseminated anhedral equant grains up to $0.2 \mathrm{~mm}$, but generally less than $0.05 \mathrm{~mm}$ in diameter. Apatite $(0.5 \%)$ may occur either as larger stubby crystals averaging about $0.1 \mathrm{~mm}$ in length with $2: 1$ to $4: 1$ length:width ratios, or as minute acicular microlites less than $0.02 \mathrm{~mm}$ in length. Zircon is euhedral in prisms less than $0.02 \mathrm{~mm}$ in length with 2:1 to 3:1 length:width ratios.

The granite is weakly hydrothermally altered. Plagioclase may be partially altered to various combinations of sericite, calcite, and epidote; hornblende to chlorite, calcite and epidote; biotite to chlorite rutile; sphene to leucoxene, and magnetite-ilmenite to hematite and/or, more rarely, leucoxene.

Relatively large grains of colorless to pale green muscovite, texturally similar to and commonly interlayered with biotite, occur in scattered traces throughout the granite. The muscovite may be primary in origin or it may be a hydrothermal or deuteric alteration product of biotite, al though this relationship is not clearly demonstrated.

f. Microdiorite and Andesite. Dense gray microdiorites and andesites and their porphyritic equivalents occur in minor amounts in several short sample intervals in C/T-2 above $838.2 \mathrm{~m}(2750 \mathrm{ft}) ; 298.7-303.3 \mathrm{~m}(980-995 \mathrm{ft})$; 423.7-428.3 m (1390-1405 ft); 464.8-469.4 m (1525-1540 ft); 758.9-762 m (2490-2500 ft) and form the bulk of samples between $1045.4 \mathrm{~m}(3430 \mathrm{ft})$ and $1063.7 \mathrm{~m}(3490 \mathrm{ft})$. A11 are characterized by the presence of golden-brown to deep russet-brown oxyhornblende. Although compositionally similar, these rocks may be texturally disparate, even within a single chip sample. All gradations exist between sparsely porphyritic andesites with cryptocrystalline matrix and phaneritic-microcrystalline diorites. A given variety may be either flow-foliated or massive. Such variation probably reflects both multiple cogenetic intrusion as well as chilling and differential flowage 
within a single intrusion.

The microdiorites and andesites in C/T-2 are almost certainly correlative with the Tertiary microdiorite dikes mapped at the surface by Nielson et al. (1978, p. 29). A typical example of microdiorite in the drill hole intrudes granodiorite between $1045.4 \mathrm{~m}(3430 \mathrm{ft})$ and $1063.7 \mathrm{~m}(3490 \mathrm{ft})$. In thin section, this rock is primarily a microcrystalline aggregate of plagioclase, oxyhornblende and biotite with lesser amounts of quartz, potassium feldspar, magnetite-ilmenite, tremolite, apatite and sphene. Plagioclase and oxyhornblende are typically elongate, averaging about $0.07 \times 0.2 \mathrm{~mm}$ (up to 0.4 $\times 0.2 \mathrm{~mm}$ ) in longitudinal section, and are randomly oriented. Biotite (12\%), pleochroic from light greenish-brown to medium greenish-brown, forms disseminated irregular shreddy crystals averaging about $0.07 \mathrm{~mm}$ (up to $0.2 \mathrm{~mm}$ ) in length or diameter, as well as irregular aggregates of the crystals up to $0.5 \mathrm{~mm}$ in maximum dimension. Quartz $(7 \%)$ and potassium feldspar $(7 \%)$, singly or intergrown, occur in irregular to polygonal masses up to $0.1 \mathrm{~mm}$ in diameter interstitial to the main rock-forming minerals. Tremolite, conspicuously anomalous at $7 \%$ of the microdiorite, occurs as acicular slightly greenish transparent needles, up to $0.1 \times 0.01 \mathrm{~mm}$ in longitudinal section, which commonly form oriented clusters of 10 or more crystals. The mineral is most commonly embedded in plagioclase, but also to a lesser extent in other rock-forming minerals. Apatite $(3 \%)$ is texturally identical to, and commonly difficult to distinguish from, tremolite, but the latter, by contrast, shows inclined extinction and generally higher birefringence. Magnetite-ilmenite, also abundant in the microdiorite (5\%), occurs as disseminated anhedral to subhedral equant grains averaging less than $0.01 \mathrm{~mm}$ in diameter. Sphene (0.7\%) forms anhedral grains up to $0.2 \mathrm{~mm}$ in length or diameter.

Microdiorites above $838.2 \mathrm{~m}(2750 \mathrm{ft})$ in C/T-2 are mineralogically very similar to the microdiorite just described (though devoid of tremolite) but are generally porphyritic-to-seriate in texture. Plagioclase and oxyhornblende phenocrysts may form up to $10 \%$ and $17 \%$, respectively, of the porphyritic variants. Plagioclase phenocrysts are euhedral, commonly twinned and/or vaguely zoned, may be either lath-shaped or roughly equant, and may reach $1 \mathrm{~mm}$ (av. $0.3 \mathrm{~mm}$ ) in maximum dimension. Lath-shaped euhedral oxyhornblende phenocrysts may reach $0.2 \mathrm{~mm}$ (av. $0.1 \mathrm{~mm}$ ) in length. In these microdiorite porphyries groundmass is nearly identical to, though more finely 
crystalline than, the microdiorite between $1045.4 \mathrm{~m}(3430 \mathrm{ft})$ and $1063.7 \mathrm{~m}$ $(3490 \mathrm{ft})$. It may be locally prominently flow-foliated.

The sample interval between $423.7 \mathrm{~m}(1390 \mathrm{ft})$ and $428.2 \mathrm{~m}(1405 \mathrm{ft})$ contains, in addition to microdiorite, about 15\% oxyhornblende andesite porphyry. The porphyry is formed of sharply euhedral oxyhornblende and plagioclase phenocrysts embedded in a dense, locally flow-foliated cryptocrystalline groundmass, which, like all microdiorites in the drill hole, is rich in disseminated magnetite-ilmenite.

2. Alteration and Inferred Structure. All rock types along the entire sampled length of Well C/T-2 have been more or less altered, particularly within and near probable fault or cataclasite zones. Alteration minerals documented to date in $\mathrm{C} / \mathrm{T}-2$ by petrographic examination and $\mathrm{X}$-ray diffraction comprise quartz, sericite, mixed-layer illite-montmorillonite, chlorite, epidote, leucoxene, hematite, calcite, secondary potassium feldspar and anhydrite. These minerals, except potassium feldspar and anhydrite, are typical of propylitic alteration or lower greenschist-facies metamorphism. Alteration minerals identified petrographically and by $X$-ray diffraction are listed in Tables 2-I and 2-III.

Alteration and inferred structural disruption are notably more intense above $844.3 \mathrm{~m}(2770 \mathrm{ft})$ than below this depth. At least three major and numerous minor altered cataclasite zones were penetrated above this footage: only two such zones were encountered between $844.3 \mathrm{~m}(2770 \mathrm{ft})$ and $2095.4 \mathrm{~m}$ $(6875 \mathrm{ft}): 1450.8-1453.8 \mathrm{~m}(4760-4770 \mathrm{ft})$ and $1764.7-1770.8 \mathrm{~m}(5790-5810 \mathrm{ft})$.

Altered cataclasites in $\mathrm{C} / \mathrm{T}-2$ are typically dense, light-to-medium grayish-green, and aphanitic to very finely-crystalline. They locally display prominent streaky foliation. In thin section, the cataclasites are observed to consist of finely comminuted rock flour, with scattered larger clasts, microveined or cemented and partially replaced by one or more of the minerals quartz, chlorite, sericite and calcite with minor epidote, hematite, leucoxene, and pyrite.

Chlorite in the altered cataclasites is light yellowish- to brownish-green with moderately high birefringence. It occurs as a constituent of microveinlets and matrix and partially to completely replaces original mafic minerals, or rarely plagioclase. It may form fans and rosettes up to 
TABLE 2-III

MINERALOGY OF CLAY SEPARATES,

SELECTED SAMPLES FROM WELL

C/T-2 AS DETERMINED BY X-RAY

DIFFRACTION.

(m)

$\begin{array}{cc}\text { 213.4-222.5 } & 7 \\ 329.2-332.2 & 108 \\ 364.2-368.8 & 11 \\ 464.8-469.4 & 15 \\ 492.3-496.8 & 16 \\ 592.8-897.4 & 19 \\ 835.2-838.2 & 27 \\ 914.8-944.9 & 3090 \\ 1051.6-1054.6 & 3450 \\ 1350.3-1353.3 & 4430 \\ 1450.8-1453.9 & 47 \\ 1527.0-1530.1 & 50 \\ 1764.8-1767.8 & 57 \\ 1905.0-1908.0 & 6250 \\ 2026.9-2030.0 & 6650\end{array}$

(ft)

700-730

1080-1090

$1195-1210$

$1525-1540$

$1615-1630$

$1945-1960$

2740-2750

3090-3100

$3450-3460$

$4430-4440$

$4760-4770$

$5010-5020$

$5790-5800$

$6250-6260$

$6650-6660$
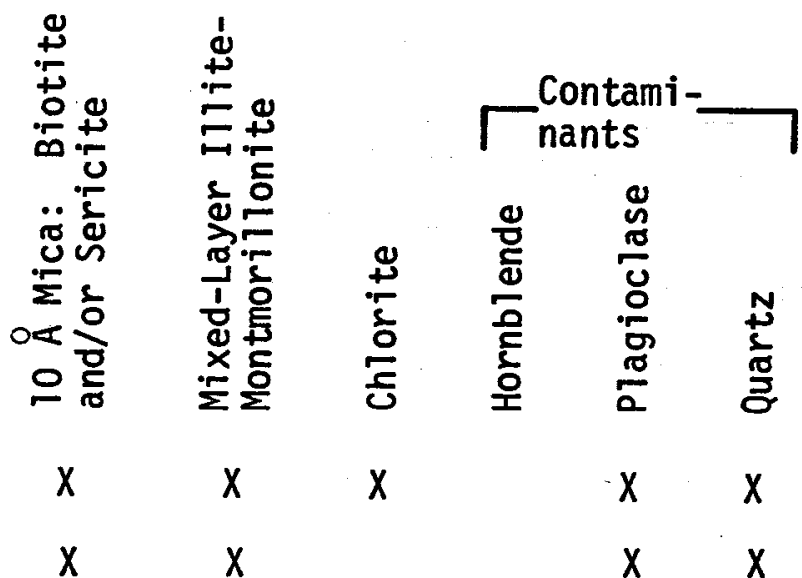

$x \quad x$

$x \quad x$

$x \quad x$

$x \quad x$

$x \quad x$

$x \quad x$

$\begin{array}{llllll}x & x & x & x & x\end{array}$

$x$

$x \quad x \quad x$

$x \quad x \quad x \quad x \quad x$

$x$

$x$

$x$

$x$

$x$

$x$

$x$

$x$

$x$
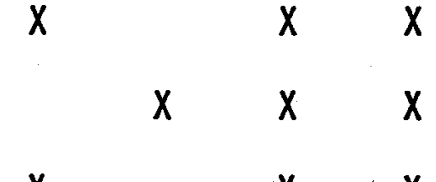

$x$

$x$

$x$

$x$

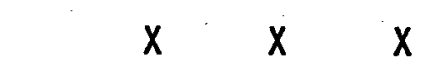

$x$

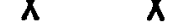

$x \quad x$

$x \quad x$

$x \quad x$

$x \quad x$ 
$0.3 \mathrm{~mm}$ (but generally less than $0.05 \mathrm{~mm}$ ) in diameter. These textures are best developed in the cataclasite zone between $1450.8 \mathrm{~m}(4760 \mathrm{ft})$ and $1453.8 \mathrm{~m}$ $(4770 \mathrm{ft})$. A microprobe analysis of chlorite from this zone is shown in Table 2-II.

Two varieties of secondary quartz occur in the altered cataclasites. The typical and most widespread variety consists of highly irregular grains averaging less than $0.02 \mathrm{~mm}$ in diameter or length and forming, generally together with other alteration minerals, microveinlets and irregular mosaic matrix aggregates. Between $838.2 \mathrm{~m}(2750 \mathrm{ft})$ and $844.3 \mathrm{~m}(2770 \mathrm{ft})$ and in traces between $675.1 \mathrm{~m}(2215 \mathrm{ft})$ to $679.7 \mathrm{~m}(2230 \mathrm{ft})$ and $734.5 \mathrm{~m}(2410 \mathrm{ft})$ and $740.6 \mathrm{~m}(2430 \mathrm{ft})$, secondary quartz forms late-stage, terminated, clear euhedral crystals up to $2 \mathrm{~mm}$ in length and $1 \mathrm{~mm}$ in diameter.

Sericite in the cataclasite typically forms minute fibers less than 0.05 $\mathrm{mm}$ in length replacing plagioclase and rock flour, or intergrown with other alteration minerals in microveinlets and matrix. It also forms rare, slightly larger greenish to transparent crystals (actually muscovite) apparently pseudomorphing original biotite.

Calcite and epidote in the cataclasites occur as minor microveinlet and matrix constituents and partially replace hornblende, pyroxene and plagioclase. Calcite may also locally partially replace sphene.

All the cataclasites contain minor magnetite-ilmenite and sphene. The former is invariably partially replaced by maroon- to brick-red submetallic hematite \pm leucoxene; the latter by dense light gray to white leucoxene \pm calcite. Magnetite-ilmenite apparently has a dual origin in the cataclasites. Most cataclasite is fragmental and obviously derived from the pre-existing rock. Vermiform blebs of magnetite-ilmenite in microveinlets and matrix, however, suggest addition to the cataclasites during hydrothermal alteration. Hematization of dark opaque minerals occurs along the entire length of C/T-2 and is clearly secondary in origin. Sphene. is apparently all relict.

With few exceptions, alteration mineralogy away from cataclasite zones in $\mathrm{C} / \mathrm{T}-2$ is petrographically similar to, though much less intense than, alteration within these zones. Microveinlets and veinlet fragments of the principal alteration minerals in all combinations are ubiquitous, but rarely account for more than a fraction of a percent of a given sample. Chlorite and sericite as microveinlet constituents increase in frequency and volume with 
proximity to cataclasite zones.

Partial replacement of original rock-forming minerals is the dominant alteration mode away from the cataclasites. Plagioclase is replaced by sericite and epidote and, above $838.2 \mathrm{~m}(2750 \mathrm{ft})$, by clay, presumably of supergene origin. $X$-ray diffraction of representative samples shows the clay to be mixed-layer illite-montmorillonite (Table 2-III). Hornblende, and, to a lesser extent, pyroxene, are replaced by chlorite, calcite, epidote, and clay. The chlorite replacing these mafics is petrographically identical to the chlorite of the cataclasite zones. Biotite is also partially chloritized, but by a distinctive bright green chlorite with anomalous blue, red, and yellowish-brown birefringence. This chlorite locally contains sagenitically arranged rutile needles. Quartz and potassium feldspar are generally unaltered, although the local cloudy appearance and mottled extinction of the latter may be due to very weak argillization.

Pyrite, rarely accompanied by texturally similar chalcopyrite, occurs at least in traces throughout C/T-2. It is, however, concentrated within and adjacent to cataclasite zones and hornblende-rich units above $844.3 \mathrm{~m}$ (2770 $\mathrm{ft}$ ). The pyrite is found as disseminated, anhedral to subhedral grains up to $0.30 \mathrm{~mm}$, but typically less than $0.10 \mathrm{~mm}$ in diameter, but it also occurs as similar grains with other alteration minerals in micro veinlets and matrix aggregates. Among the rock forming minerals, magnetite-ilmenite, hornblende and plagioclase are the preferred hosts, in decreasing order of susceptibility, for sulfide replacement.

Anhydrite first appears in thin section between $574.5 \mathrm{~m}(1885 \mathrm{ft})$ and $583.7 \mathrm{~m}$ (1915 ft) where it occurs as a single fragment, $0.15 \times 0.1 \mathrm{~mm}$ in size, cut by a chlorite microveinlet. It next occurs in plagioclase between $1018 \mathrm{~m}$ $(3340 \mathrm{ft})$ and $1021 \mathrm{~m}(3350 \mathrm{ft})$ as a microveinlet and adjoining irregular replacement patch, measuring $0.1 \times 0.03 \mathrm{~mm}$. Anhydrite is then absent until $1615.4 \mathrm{~m}$ ( $5300 \mathrm{ft})$, below which it is present in nearly every sample. In all these lower samples, it occurs only as discrete drill-broken crystal fragments, up to $0.2 \mathrm{~mm}$ in diameter, almost certainly derived from veins.

Secondary potassium feldspar first appears in C/T-2 between $574.5 \mathrm{~m}$ (1885 $\mathrm{ft})$ and $583.7 \mathrm{~m}(1915 \mathrm{ft})$. Here it is present in trace amounts as irregular discontinuous selvages on quartz and quartz-chlorite veinlets. Similar trace occurrences were documented in the following samples: $829 \mathrm{~m}(2720 \mathrm{ft})$ to 
$832.1 \mathrm{~m}(2730 \mathrm{ft}), 838.2 \mathrm{~m}(2750 \mathrm{ft})$ to $841.2 \mathrm{~m}(2760 \mathrm{ft}), 841.2 \mathrm{~m}(2760 \mathrm{ft})$ to $844.3 \mathrm{~m}(2770 \mathrm{ft})$. Secondary potassium feldspar is probably more abundant in the drill hole than reported here. In finely ground drill cuttings, secondary potassium feldspar is difficult to distinguish from primary potassium feldspar in perthite, antiperthite, or in granophyric intergrowths with quartz.

Calcite, an alteration production that can be readily separated from its host rock, was extracted from selected samples from C/T-2 for oxygen and carbon isotope analysis. The calcite partially replaces, in descending order of susceptibility to alteration, plagioclase, hornblende, pyroxene, and sphene. It also occurs as a common constituent of microveinlets and cataclasite. Calcite is ubiquitous in Well $\mathrm{C} / \mathrm{T}-2$, but is concentrated in the upper portion of the well (above $838.2 \mathrm{~m}(2750 \mathrm{ft})$ ) and in fault and cataclasite zones, particularly those centered on $838.2 \mathrm{~m}(2750 \mathrm{ft}), 1453.8 \mathrm{~m}$ $(4770 \mathrm{ft})$ and $1767.8 \mathrm{~m}(5800 \mathrm{ft})$. Paragenetic relationships for calcite relative to other alteration minerals in Well $\mathrm{C} / \mathrm{T}-2$ are ambiguous, but cross-cutting veinlets indicate multiple periods of calcite deposition.

The small size of drill cuttings from C/T-2 hinders determination of paragenetic relationships among alteration minerals. Where larger chips and/or pervasive alteration permit such a determination, these relationships are generally ambiguous. In one sample, for instance, a given alteration mineral may clearly predate another, whereas in a second sample the reverse may be true. In spite of these difficulties, a number of paragenetic relationships among alteration minerals in $\mathrm{C} / \mathrm{T}-2$ can be established with some confidence:

(1) Hornblende and biotite after clinopyroxene, and biotite after hornblende are the earliest alteration products. They are consistently replaced by or cut by microveinlets of all other alteration minerals, and are probably magmatic, deuteric, or metamorphic in origin.

(2) Microveinlets of chlorite $\neq$ quartz $\neq$ magnetite-ilmenite $\neq$ pyrite postdate all other alteration minerals except clay in the upper portion of the hole and quartz between $835.1 \mathrm{~m}(2740 \mathrm{ft})$ and $838.2 \mathrm{~m}(2750 \mathrm{ft})$. The chlorite in these microveinlets is petrographically identical to the chlorite of cataclasites mapped at the surface by Nielson and others (1978). 
(3) Small, clear euhedral quartz crystals in the altered fault zone between $835.1 \mathrm{~m}(2740 \mathrm{ft})$ and $838.2 \mathrm{~m}(2750 \mathrm{ft})$ apparently line open spaces in the veinlets described above, and therefore postdate these veinlets.

(4) Veinlets and irregular patches of illite-montmorillonite are confined to the portion of the hole above $838.2 \mathrm{~m}(2750 \mathrm{ft})$ and postdate all other alteration minerals. The clay may be largely of supergene origin.

Discussion. Hydrothermal alteration observed in Well $\mathrm{C} / \mathrm{T}-2$ is texturally and mineralogically similar to that observed at intermediate-todeep levels in other holes within the Roosevelt Hot.Springs KGRA, including Utah State Geothermal Wells 72-16 (Rohrs and Parry, 1978), 14-2 (Parry, 1978; Ballantyne and Parry, 1978; Ballantyne, J. M., 1978) and 52-21 (Ballantyne, G. H., 1978) (Fig. 1.2). Near-surface alteration in C/T-2 could not be characterized due to an absence of cuttings between ground level and $121.9 \mathrm{~m}$ $(400 \mathrm{ft})$.

The age of alteration in $\mathrm{C} / \mathrm{T}-2$ relative to present geothermal activity is unknown. Sinter deposits and altered alluvium penetrated by shallow diamond drill holes along the Opal Mound Fault (DDH 1A, 1B and 76-1; Bryant and Parry, 1977; Parry, et al., 1980) (Fig. 1-2) and altered alluvium in Utah State 72-16 (Rohrs and Parry, 1978) are clearly of recent geothermal origin. Other alteration at Roosevelt, however, may be partially paleohydrothermal. Cataclasites and mylonites and adjacent host rocks exposed in the west-central Mineral Mountains and within the KGRA, for instance, are typically altered to various combinations of chlorite, sericite, quartz, hematite, and epidote (Nielson, et al., 1978). Epidote normally forms at temperatures greater than $220^{\circ} \mathrm{C}$ (Zen and Thompson, 1964). Its present occurrence at the surface at Roosevelt suggests formation at deeper levels before present geothermal activity, then subsequent exposure by erosion. B. Sibbett (personal communication, 1980) has observed fresh glassy rhyolite flows, dated at 0.8 to 0.5 m.y. (Lipman, et al., 1978), resting on strongly chloritized, silicified and hematized cataclasite within the KGRA. This relationship strongly suggests a pregeothermal origin for the alteration. 


\section{Intervals Selected for Detailed Geochemical and Isotopic}

Investigation. Four intervals in Well $\mathrm{C} / \mathrm{T}-2$ were selected for detailed geochemical and isotopic study: 1066.7-1097.2 m (3500-3600 ft); 1758.6-1804.3 $\mathrm{m}(5770-5920 \mathrm{ft}) ; 1904.9-1935.4 \mathrm{~m}(6250-6350 \mathrm{ft})$; and 2023.8-2057.3 $\mathrm{m}$ $(6660-6750 \mathrm{ft})$. The upper interval is in the cased portion of the hole and was chosen to provide calibration data for gamma-ray logging tools at moderate temperatures. The three lower intervals are all uncased, and were selected as potentially useful for calibrating gamma-ray and neutron logging equipment at high temperatures.

The interval 1066.7-1097.2 $\mathrm{m}(3500-3600 \mathrm{ft})$ spans the contact at $1082.0 \mathrm{~m}$ $(3550 \mathrm{ft})$ between the upper hornblende biotite granodiorite and subjacent hornblende-biotite granite.

The interval 1758.6-1804.3 $\mathrm{m}(5770-5920 \mathrm{ft})$ includes the contact at $1776.9 \mathrm{~m}(5830 \mathrm{ft})$ between hornblende biotite quartz monzonite and the lower granodiorite. The interval also includes a fault zone between $1764.7 \mathrm{~m}$ (5790 $\mathrm{ft})$ and $1770.8 \mathrm{~m}(5810 \mathrm{ft})$

The two lower intervals, 1904.9-1935.4 $\mathrm{m}(6250-6260 \mathrm{ft})$ and 2923.8-2057.3 $m(6650-6750 \mathrm{ft})$, are both in the lower hornblende-biotite granodiorite. Both intervals show strong gama-ray and neutron log anomalies, which do not correlate with readily apparent lithologic variations. Both intervals, however, (especially 2023.8-2057.3 m-(6650-6750 ft)) are characterized by slightly more intense alteration and mineralization than is typical for the lower portion of $\mathrm{C} / \mathrm{T}-2$.

\section{GEOCHEMISTRY}

\section{A. Introduction}

Chemical analyses of cuttings from Well C/T-2 have been completed with two principal objectives in mind. First, various types of analyses can be useful in the interpretation of the genesis of geothermal systems and location of fluid entries within drill holes. Second, several of the geophysical logging techniques that will be discussed in a subsequent section measure chemical properties. The most obvious of these is the gamma $\log$, which measures the gamma radiation produced by the natural decay of uranium, thorium, and potassium. In addition, several elements have extremely large 
thermal neutron capture cross sections and are thus important in the evaluation of neutron logs.

B. Methods and Procedures

All cuttings samples for chemical analysis from Well C/T-2 were thoroughly washed to remove drilling mud, lost-circulation material and other contaminants. The samples were then cleaned of iron drill bit and drill rod shavings with a hand magnet. Composite samples were prepared at the rate of 1 $\mathrm{g}$ of sample/ft of drill hole. Before analysis, both individual and composite samples (except for closed-can gamma-ray spectrometry) were pulverized to a fine powder ( $<270$ mesh) in a Spex shatterbox.

Individual samples from the selected intervals of Well C/T-2 were analyzed for $\mathrm{Si}, \mathrm{Ti}, \mathrm{Al}, \mathrm{Fe}, \mathrm{Mn}, \mathrm{Mg}, \mathrm{Ca}, \mathrm{P}, \mathrm{Nb}, \mathrm{Zr}, \mathrm{Y}, \mathrm{Sr}, \mathrm{Rb}, \mathrm{Th}, \mathrm{Pb}, \mathrm{Ba}$ and $U$ by $X$-ray fluorescence (XRF) using a Norelco (Phillips Electronics Instruments) $X$-ray fluorescence spectrograph. For each sample, two disks were prepared for analysis. Fused glass disks were used for $\mathrm{Si}, \mathrm{Ti}, \mathrm{Al}, \mathrm{Fe}, \mathrm{Mn}$, $\mathrm{Mg}, \mathrm{Ca}$ and $\mathrm{P}$. All other analyses were obtained from powder disks prepared by mixing $1 \mathrm{~g}$ of chromatographic cellulose with $1 \mathrm{~g}$ of sample and pressing the mixture into an aluminum cap with 20 tons pressure. XRF analytical techniques used for Si, Ti, Al, Fe, Mn, Mg, Ca and P are those of Norrish and Hutton (1969). Uranium analyses required the methods of James (1977). All other XRF analyses were obtained by the methods of Jack and Carmichael (1969): For barium, these methods were modified by F. Brown, of the University of Utah Department of Geology and Geophysics. Sodium and potassium analyses were obtained by lithium metaborate fusion and flame photometry using techniques outlined by Suhr and Ingamells (1966).

Sulfur analyses for the four selected intervals from Well C/T-2 were completed with a LECO sulfur analyzer. For each analysis by this method, measured quantities of sample, $\mathrm{Sn}$ and $\mathrm{Fe}$ are inductively furnace-heated in a stream of oxygen, producing $\mathrm{SO}_{2}$ that is then analyzed by titration with potassium iodide.

Uranium in samples from the selected intervals was also determined by fluorometry, using a Jarrel-Ash fluorometer. In fluorometric analysis, each sample is digested in $\mathrm{HCLO}_{4}, \mathrm{HNO}_{3}$ and $\mathrm{HF}$, then mixed with ethyl acetate. The resulting mixture is fused with a flux in a platinum disk, then excited by 
ultra-violet radiation, causing the sample to fluoresce. The fluorescence of the sample is compared with that of standards containing known quantities of uranium.

Closed-can gamma-ray spectrometry was used to determine $K, T h$, and $U$ concentrations in samples from the selected intervals of Well $\mathrm{C} / \mathrm{T}-2$. Analyses were obtained with a Tracor-Northern multichannel gamma-ray spectrometer. Each cuttings sample was completely sealed in a can to prevent leakage of radon gas. The sealed sample was allowed to sit for $4 \mathrm{~h}$, then counted for $2000 \mathrm{~s}$. A second reading of the same duration was obtained four days later, the results averaged, and the counts converted to $K$, Th and $U$ values.

Arsenic concentrations in samples from the four selected intervals and in $100 \mathrm{ft}$ composite samples were obtained by colorimetric methods. Sample preparation for colorimetry begins with digestion in $\mathrm{HF}, \mathrm{HClO}_{4}$ and $\mathrm{HCl}$. Arsenic in the acidified sample is reduced to a trivalent state by the addition of potassium iodide and stannous chloride solutions. Zinc is added and reacts with the acid, liberating hydrogen gas, which forms arsine from the arsenic in the sample. The arsine is bubbled into a solution of pyridine and silver diethyldithiocarbamate, with which the arsine forms a colored complex that is compared to standards.

Mercury analyses for composite samples and samples from the selected intervals of $\mathrm{C} / \mathrm{T}-2$ were obtained with a Jerome Instruments Model 301 gold-film detector. For this technique a weighed portion of each sample is heated in a closed tube to greater than $600^{\circ} \mathrm{C}$ to release $\mathrm{Hg}$ vapor. The vapor collects on a gold film, and concentration is measured by the resultant change in electrical resistance of the film.

Individual samples from the four selected intervals from Well $\mathrm{C} / \mathrm{T}-2$ and $100 \mathrm{ft}$ composite samples from the entire sampled length of the well were analyzed for the following elements by plasma spectrometry: $\mathrm{Na}, \mathrm{K}, \mathrm{Ca}, \mathrm{Mg}$, $\mathrm{Fe}, \mathrm{Al}, \mathrm{Ti}, \mathrm{P}, \mathrm{Sr}, \mathrm{Ba}, \mathrm{V}, \mathrm{Cr}, \mathrm{Mn}, \mathrm{Co}, \mathrm{Ni}, \mathrm{Cu}, \mathrm{Mo}, \mathrm{Pb}, \mathrm{Zn}, \mathrm{Cd}, \mathrm{Au}, \mathrm{Ag}, \mathrm{Sb}, \mathrm{Bi}$, $\mathrm{Te}, \mathrm{Sn}, \mathrm{W}, \mathrm{Li}, \mathrm{Be}, \mathrm{Zr}, \mathrm{La}, \mathrm{Ce}$, and Th. Analyses were obtained with a Model 137 Applied Research Laboratories Inductively Coupled Plasma Quantometer (ICPQ) with a 1080-1ine/mm grating and computer operating system which automatically performs calibration, matrix interference correction, and background subtraction.

Sample preparation for analysis by ICPQ commences with oven-drying a 1-g 
portion for at least $2 \mathrm{~h}$ at $120^{\circ} \mathrm{C}$. This dried portion is then digested, in several stages, in $\mathrm{HF}, \mathrm{HClO}_{4}, \mathrm{HCl}$, and $\mathrm{HNO}_{3}$. The digestion yields for analysis an aqueous solution with approximate concentrations of $5 \% \mathrm{HClO}_{4}, 10 \%$ $\mathrm{HNO}_{3}$, and $1 \%$ total dissolved solid.

\section{Geochemistry of Composite Samples}

Numerous studies have drawn attention to the analogy between geothermal systems and the systems that have produced hydrothermal ore deposits (Ewers and Keays, 1977). The suite of metals that are concentrated in geothermal systems are similar to those that are found in epithermal ore deposits. Efforts are currently under way to understand the geochemical relationships in these systems and to adapt this understanding to the formulation of geochemical exploration methods (Bamford, 1968; Bamford, et al., 1980).

Several periods of hydrothermal activity can be documented in the Roosevelt geothermal area. The youngest period is the current one with alteration and mineral deposition being concentrated along the three major structural trends that have been discussed previously. 'Low-angle normal faulting, the oldest fault episode recognized in the area, was accompanied by hydrothermal activity. Numerous small exploration pits containing shows of malachite, chalcopyrite, and pitch limonite have been found along the mapped fault zones (Nielson et al., 1978; Sibbett and Nielson, 1980). In addition, small mineralized areas within the plutonic phases suggest that the intrusive episodes may have generated small hydrothermal systems, although age relationships are speculative at this time.

A geochemical reconnaissance study of $C / T-2$ was done to help evaluate the evolution of the geothermal system in this area and to allow comparison with data from the rest of the field. Whole rock samples were composited at $30.5 \mathrm{~m}$ $(100-\mathrm{ft})$ intervals and analyzed using an ICPQ. These results are shown in Table 3-I and selected elements are plotted as a function of depth in Fig. 3-1. Bamford et al. (1980) have suggested that $\mathrm{Li}, \mathrm{As}, \mathrm{Hg}, \mathrm{Mn}, \mathrm{Zn}$, and $\mathrm{Sr}$, are important elements in evaluating the behavior of the geothermal system. In $\mathrm{C} / \mathrm{T}-2, \mathrm{Mn}, \mathrm{Sr}$, and $\mathrm{Zn}$ show a strong correlation with rock type and are probably not geothermal indicators.

The hanging wall of the low-angle fault (above $844.0 \mathrm{~m}$ [2750 ft]) shows anomalous concentrations of $\mathrm{Li}, \mathrm{As}$, and $\mathrm{Hg}$. An especially strong $\mathrm{Hg}$ anomaly 
TABLE 3-I

CHEMICAL ANALYSIS OF COMPOSITE

SAMPLES FROM WELL $C / T-2$

\section{ELEMENT}

$\mathrm{Na}$

$\mathrm{K}$

Ca

$\mathrm{Mg}$

$\mathrm{Fe}$

A1

Ti

P

$\mathrm{Sr}$

$\mathrm{Ba}$

$V$

$\mathrm{Cr}$

$\mathrm{Mn}$

Co

$\mathrm{Ni}$

$\mathrm{Cu}$

Mo

$\mathrm{Pb}$

Zn

Cd

Ag

Au

As

$\mathrm{Sb}$

$\mathrm{Bi}$

$\mathrm{Te}$

Sn

Li

$\mathrm{Be}$

$\mathrm{Zr}$
$\mathrm{La}$
$\mathrm{Ce}$
$\mathrm{Th}$
121.9$149.4 \mathrm{~m}$ (400-

$490 \mathrm{ft})$

\% OX.

$\%$ OX.

$\%$ OX.

$\%$ OX.

$\%$ OX.

$\%$ OX.

$\%$ OX.

$\%$ OX.

PPM

$\% 0 X$

PPM

PPM

$\%$ OX.

PPM

PPM

PPM

PPM

PPM

PPM

PPM

PPM

PPM

PPM $<30.0$
PPM $<100$

PPM
PPM

\subsection{5}

5.22

1.01

0.105

0.855

15.75

0.387
0.049

350

0.154

250
4

0.013

36

3.00
$6 \quad 6$

< $\quad 50.0$

42

12

$<\quad 5.00$

4.0

$$
<\quad 50.0
$$

$5.00<$
$<\quad 2.00<$

$<4.00<$

$50.0<$
$5.00<$

PPM

4

1.4

PPM

PPM

PPM

PPM
PPB

16

26

57

50
150

10

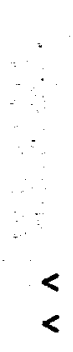

149.4(490-

$580 \mathrm{ft}$ )

4.02

5.77

0.757

0.144

0.922

15.79

0.240

0.055

348

0.157

$<\quad 250$

5

0.009

41

$<$

$<$

27

5.00

$$
5.00
$$

50.00

27

15

5.00

2.00

4.00

6.0

$<\quad 30.0$
$<\quad 100$

$$
<\quad 50.0
$$

5.00

4

1.4

$\begin{array}{r}11 \\ 22 \\ 4 \quad 44 \\ <\quad 150 \\ \hline\end{array}$ $176.8 \mathrm{~m}$

176.8-

$204.2 \mathrm{~m}$

(580-

$204.2-$

$240.8 \mathrm{~m}$

(670-

$790 \mathrm{ft})$

4. 37

6.13

0.829

0.089

0.615

16.04

4.06

4.57

2.84

1.13

4.11

14.68

$\begin{array}{cc}0.129 & 1.18 \\ 0.042 & 0.430 \\ 385 & 660\end{array}$

$0.164 \quad 0.113$

$<250<250$

$<2.00<2.00$

0.010

48

$<\quad 5.00$

$<\quad 5.00$

$<\quad 50.00$

21

10

$<5.00<$

$<2.00<$

$<4.00<$

3.0

$<100$

$<\quad 30.0$

$<100$

$\begin{array}{lll}<\quad 50.0 & <\quad 50.0 \\ <\quad 5.00 & <5.00\end{array}$
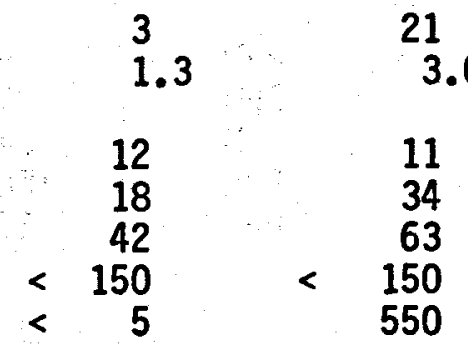
ELEMENT

$\mathrm{Na}$

$\mathrm{K}$

$\mathrm{Ca} \quad \%$ OX.

$\mathrm{Mg} \quad \%$ OX.

$\mathrm{Fe} \quad \%$ OX.

A1 $\%$ OX.

Ti

$P$

$\mathrm{Sr}$

$\mathrm{Ba}$

V

$\mathrm{Cr}$

$\mathrm{Mn}$

Co

$\mathrm{Ni}$

$\mathrm{Cu}$

Mo

$\mathrm{Pb}$

$\mathrm{Zn}$

Cd

$\mathrm{Ag}$

$\mathrm{Au}$

As

$\mathrm{Sb}$

$\mathrm{Bi}$

Te

Sn

Li

$\mathrm{Be}$

$\mathrm{Zr}$

La

$\mathrm{Ce}$

Th

$\mathrm{Hg}$ -

$\%$ ox.

$\%$ ox.

PPM

PPM

PPM

$\%$ OX.

PPM

PPM

PPM

PPM
PPM

PPM

PPM

PPM

PPM

PPM

PPM

PPM

PPB

TABLE 3-I (cont.)

\begin{tabular}{|c|c|c|c|}
\hline $\begin{array}{l}240.8- \\
271.3 \mathrm{~m} \\
(790- \\
890 \mathrm{ft}) \\
\end{array}$ & $\begin{array}{c}271.3- \\
303.3 \mathrm{~m} \\
(890- \\
995 \mathrm{ft}) \\
\end{array}$ & $\begin{array}{c}303.3- \\
332.2 \mathrm{~m} \\
(995- \\
1090 \mathrm{ft}) \\
\end{array}$ & $\begin{array}{c}332.2- \\
364.2 \mathrm{~m} \\
(1090- \\
1195 \mathrm{ft}) \\
\end{array}$ \\
\hline $\begin{array}{c}3.96 \\
4.56 \\
2.15 \\
0.594 \\
2.51 \\
14.12\end{array}$ & $\begin{array}{c}3.80 \\
4.52 \\
2.19 \\
0.987 \\
2.92 \\
13.96\end{array}$ & $\begin{array}{c}4.22 \\
3.31 \\
2.38 \\
0.815 \\
3.09 \\
15.18\end{array}$ & $\begin{array}{c}3.94 \\
3.17 \\
2.27 \\
0.624 \\
3.33 \\
13.56\end{array}$ \\
\hline
\end{tabular}

\% OX. $\quad 0.102$

0.573

0.209

0.629

0.234

250

PPM < 2.00

PPM < 4.00

$$
2.0
$$

0.035

39

24

439

50.0

65

50.0

50.0

0.083

$<250$

PPM $<$

311

14

2.5

$<50.0$
$<.00$
11
3.2

0.840

0.361

0.823

599

0.306

497

0.115

0.098

$<250<250$

$\begin{array}{ccc}3 & 2.00< & 2.00 \\ 0.047 & 0.038 & 0.028 \\ 41 & 51 & 39 \\ 12 & 5.00 & 5\end{array}$

$21<13.00 \quad 10$

$50.0<50.0<50.0$

PPM $\quad 9$

PPM $\quad 31$

14

54
$<\quad 150$

34

23

$44 \quad 34 \quad 26$

29

$5.00<5.00<5.00$

$2.00<2.00$

$4.00<$

4.00

4.0

2.00

1.0

$<30.0$

$<100$

4.00

15

$\begin{array}{r}57 \\ <\quad 150 \\ \hline\end{array}$

15

50.0

30.0
$<\quad 100$

6.0

11
45
79
$<\quad 36$
150
15

13

3.3 
ELEMENT

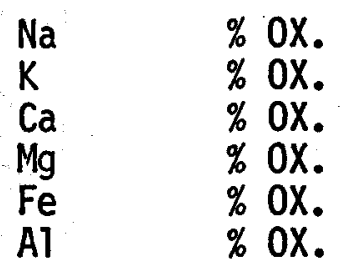

$\mathrm{Ti} \quad \%$ ox.

P \% OX.

Sr PPM

$\mathrm{Ba} \quad \% 0 X$.

$\mathrm{V}$

$\mathrm{Cr}$

$\mathrm{Mn}$

Co

$\mathrm{Ni}$

$\mathrm{Cu}$

Mo

$\mathrm{Pb}$

$\mathrm{Zn}$

Cd

$\mathrm{Ag}$

$\mathrm{Au}$

As

$\mathrm{Sb}$

$\mathrm{Bi}$

$\mathrm{Te}$

Sn

Li

$\mathrm{Be}$

$\mathrm{Zr}$

Ce

Th

$\mathrm{Hg}$

PPM

PPM

$\%$ OX.

PPM

PPM

PPM

PPM

PPM

PPM

PPM

PPM

PPM

PPM

PPM

PPM

PPM

PPM

PPM

PPM

PPB

TABLE 3-I (cont.)

$364.2-$ $387.1 \mathrm{~m}$ (1195-

$1270 \mathrm{ft}$ )

3.33

3.99

3.24

0.866

3.76

14.89

PPM $<$

PPM $<$

PPM $<$

PPM <

520

250

0.045

29

9

35

5.00

2.6

$\begin{array}{cc}0.729 & 1.05 \\ 0.252 & 0.332\end{array}$

$0.123 \quad 0.128$

$15 \quad 23$

$50.0<50.0$

$21 \quad 22$

$2.00<5.00<$

$2.00<2.00<$

4.00

4.0
$30.0<30.0$

$\begin{aligned} 30.0 & <30.0<\end{aligned}$

50.0
$5.00<50.0<$

$\begin{array}{lll}< & 50.0<\end{array}$

50.0

$14 \quad 12$

2.5

10

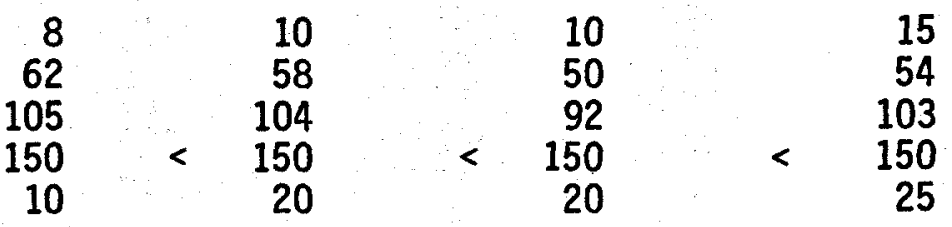


ELEMENT

$\mathrm{Na} \quad \%$ OX.

$\mathrm{K} \quad \%$ OX.

Ca $\%$ OX.

$\mathrm{Mg} \quad \%$ OX.

$\mathrm{Fe} \quad \%$ OX.

A1 $\%$ OX.

$\mathrm{Ti} \quad \% \mathrm{OX}$

$P$

Sr

$\mathrm{Ba}$

V

$\mathrm{Cr}$

$\mathrm{Mn}$

Co

$\mathrm{Ni}$

$\mathrm{Cu}$

Mo

$\mathrm{Pb}$

$\mathrm{Zn}$

$\mathrm{Cd}$

$\mathrm{Ag}$

$\mathrm{Au}$

As

$\mathrm{Sb}$

$\mathrm{Bi}$

$\mathrm{Te}$

Sn

Li

$\mathrm{Be}$

$\mathrm{Zr}$

Ce

Th

$\mathrm{Hg}$

$$
\text { PPM }
$$

$\%$ OX.

PPM

PPM

PPM

PPM

PPM
PPM

PPM

PPM

PPM

PPM

PPM

PPM

PPM

PPB

TABLE 3-I (cont.)

\begin{tabular}{|c|c|c|c|}
\hline $\begin{array}{l}483.1- \\
515.1 \mathrm{~m} \\
(1585- \\
1690 \mathrm{ft}) \\
\end{array}$ & $\begin{array}{c}515.1- \\
547.1 \mathrm{~m} \\
(1690- \\
1795 \mathrm{ft}) \\
\end{array}$ & $\begin{array}{c}547.1- \\
574.5 \mathrm{~m} \\
(1795- \\
1885 \mathrm{ft}) \\
\end{array}$ & $\begin{array}{l}574.5- \\
606.6 \mathrm{~m} \\
(1885- \\
1990 \mathrm{ft}) \\
\end{array}$ \\
\hline $\begin{array}{r}3.87 \\
3.04 \\
6.56 \\
2.66 \\
8.50 \\
15.65\end{array}$ & $\begin{array}{r}3.88 \\
3.11 \\
6.61 \\
3.03 \\
8.76 \\
16.43\end{array}$ & $\begin{array}{r}4.23 \\
2.91 \\
6.69 \\
3.12 \\
8.68 \\
17.03\end{array}$ & $\begin{array}{r}4.25 \\
2.76 \\
6.43 \\
2.35 \\
8.95 \\
16.60\end{array}$ \\
\hline $\begin{array}{r}2.03 \\
0.374 \\
724\end{array}$ & $\begin{array}{c}2.12 \\
0.387 \\
957\end{array}$ & $\begin{array}{c}2.14 \\
0.319 \\
860\end{array}$ & $\begin{array}{l}2.54 \\
0.572 \\
784\end{array}$ \\
\hline
\end{tabular}

$$
\begin{aligned}
& \text { PPM } 724 \quad 957 \\
& \% \text { OX. } \quad 0.071 \quad 0.125 \\
& \text { PPM < } 250<250
\end{aligned}
$$

4

0.137

$$
\begin{gathered}
250 \\
20 \\
0.141 \\
36
\end{gathered}
$$

45

19

106

$50.0<\quad 50.0$
38

17

59

50.0

$<$

250

$<250$

0.151

13

0.155

42

20

69

50

71

102

$<$

24

114

$$
5.00<5.00<5.00
$$

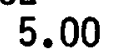

$<$

2.00

4.00

$<$

2.00

4.00

50.0
17

$4.00<$

3.0

4.0
$<\quad 30.0<30.0$

PPM $<100<100$

$<\quad 100$

$<100$

$\begin{array}{ll}\text { PPM } & <50.0 \\ \text { PPM } & <5.00\end{array}$

$50.0<$
$5.00<$

$50.0<$
$5.00<$

50.0

PPM $\quad 15$

2.5

16

PPM 21

44

87

$<\quad 150$

15
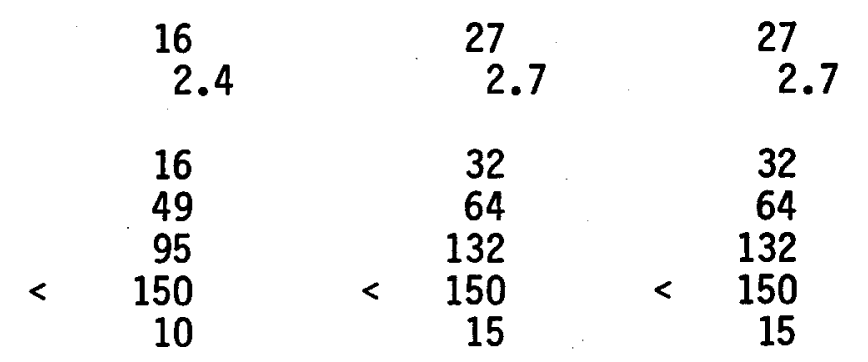
TABLE 3- I (cont.)

ELEMENT

$\mathrm{Na} \quad \%$ ox.

$\mathrm{K} \%$ OX

$\mathrm{Ca} \quad \%$ OX.

$\mathrm{Mg} \quad \%$ OX.

$\mathrm{Fe} \quad \%$ OX.

A1 \% OX.

Ti \% OX.

$\mathrm{P} \quad \%$ OX.

Sr $\quad P P M$

$\mathrm{Ba} \quad \%$ OX.

$V$

$\mathrm{Cr}$

Mn

Co

$\mathrm{Ni}$

$\mathrm{Cu}$

Mo

$\mathrm{Pb}$

Zn

Cd

$\mathrm{Ag}$

Au

As

$\mathrm{Sb}$

Bi

Te

Sn

Li

$\mathrm{Be}$

$\mathrm{Zr}$

La

$\mathrm{Ce}$

Th

$\mathrm{Hg}$

PPM

PPM

$\%$ OX.

PPM

PPM

PPM

PPM

PPM

PPM

PPM

PPM
PPM

PPM

PPM

PPM

PPM

PPM

PPM

PPM

PPM

PPM

PPM

PPB

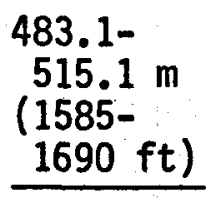

3.87

3.04

6.56

2.66

8.50

15.65

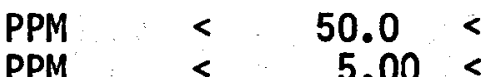

15

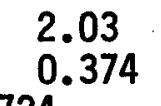

724

0.071

250

4
0.137

45

19

106

50.0

38

71

$5.00<$

$2.00<$

$4.00<$

2.0

< $30.0<$

$$
2.5
$$

21

44

87
$<\quad 150$

15
$515.1-$
$547.1 \mathrm{~m}$
$(1690-$
$1795 \mathrm{ft})$

3.88

3.11

6.61

3.03

8.76

16.43

$<\quad 100<30$.

$<\quad 5.00<$
2.12

957

0.125

250

20

0.141

36

17

59

50.0

41

102

5.00

$2.00<$

$4.00<$

3.0

100

$\begin{aligned} 50.0 & < \\ 5.00 & <\end{aligned}$

16

2.4

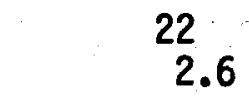

16

49

95

150

10

860

250

13

42

20

69

50.0

24

114

7.0

22

32

52

109

$<\quad 150$

10

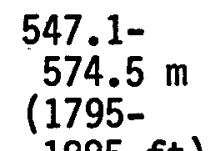

$1885 \mathrm{ft}$ )

4.23

2.91

6.69

3.12

8.68

17.03

2.14

0.085

0.151

$5.00<5.00$

$2.00<2.00$

$4.00<4.00$

$<\quad 30.0<30.0$

$<100<100$

$$
\begin{array}{cc}
50.0 & 50.0 \\
5.00 & 5.00
\end{array}
$$

27

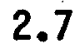


ELEMENT

$\mathrm{K}$

$\mathrm{K}$

$\mathrm{Ca}$

$\mathrm{Mg}$

Fe

Ti

$P$

Sr

$\mathrm{Ba}$

$\mathrm{Cr}$

$\mathrm{Mn}$

Co

$\mathrm{Ni}$

$\mathrm{Cu}$

Mo

$\mathrm{Pb}$

$\mathrm{Zn}$

$\mathrm{Cd}$

$\mathrm{Ag}$

$\mathrm{Au}$

As

$\mathrm{Sb}$

$\mathrm{Bi}$

Te

Sn

Li

$\mathrm{Be}$

$\mathrm{Zr}$

La

$\mathrm{Ce}$

Th

$\mathrm{Hg}$

TABLE 3-I (cont.)

$606.6-$

$638.6 \mathrm{~m}$

(1990-

$2095 \mathrm{ft}$ )

$\%$ Ox.

$\%$ OX.

$\%$ OX.

$\%$ OX.

$\%$ OX.

$\%$ OX.

$\%$ ox.

$\%$ OX.

PPM

$\%$ OX.

PPM

PPM

\% OX.

PPM

PPM

PPM

PPM
PPM

PPM
PPM

PPM

PPM

PPM

PPM

PPM

PPM

PPM

PPM

PPM

PPM

PPM

PPM

PPM

PPM

PPB

4.68

4.17

4.93

1.75

5.88

17.07

$$
1.50
$$

0.360

583

0.074

$<\quad 250$

250

20

0.098

31

12

60

$<$

50.0

83

$<$

$$
5.00
$$

8.0

8.0
$<\quad 30.0$

100

12

2.2

17
77

138

$<\quad 150$

10
2.00

$4.00<$

50.0

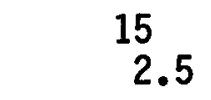

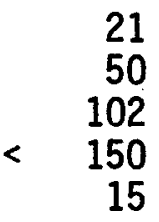

21

50

50

15
6.38.6$669.0 \mathrm{~m}$ (2.095$-2.195 \mathrm{ft}$ )

15
2.5

669.0

$701.0 \mathrm{~m}$

(2195-

$2300 \mathrm{ft}$ )

3.85

3.17

7.13

3.03

8.66

15.96

7.21
16.70

$$
1.88
$$

796

0.078

250

32

0.127

45

21

80

50.0

44

92

5.00

2.00

4.00

2.0

30.0

100

50.0

5.00
2.13
0.366
757

0.077

250

29

0.128

43

23

84

50.0

25

92

5.00

2.00

4.00

4.0

$<30.0$
$<\quad 100$

50.0

15

2.4

14

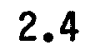

25
42
84
$\times \quad 150$
15

23

46

90

$<\quad 150$ 
TABLE 3-I (cont.)

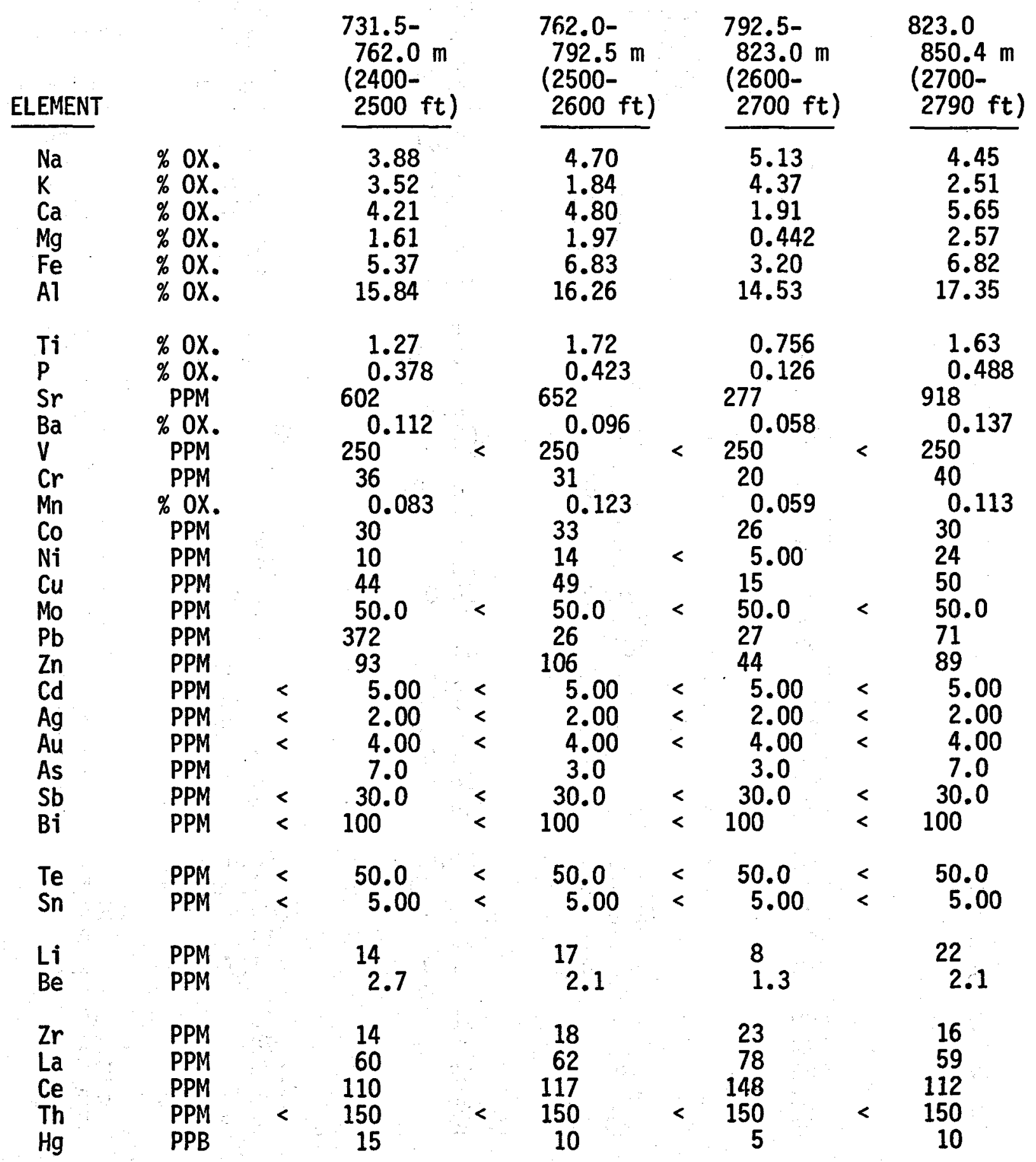




\section{ELEMENT}

$\mathrm{Na}$

K

$\mathrm{Mg}$

$\mathrm{Fe}$

Al

Ti

$P$

Sr

$\mathrm{Ba}$

$\checkmark$

$\mathrm{Cr}$

$\mathrm{Mn}$

Co

$\mathrm{Ni}$

$\mathrm{Cu}$

Mo

$\mathrm{Pb}$

$\mathrm{Zn}$

Cd

$\mathrm{Ag}$

$\mathrm{Au}$

As

$\mathrm{Sb}$

$\mathrm{Bi}$

Te

Sn

W

Li

$\mathrm{Be}$

$\mathrm{Zr}$

$\mathrm{La}$

Th

$\mathrm{Hg}$

TABLE 3-I (cont.)

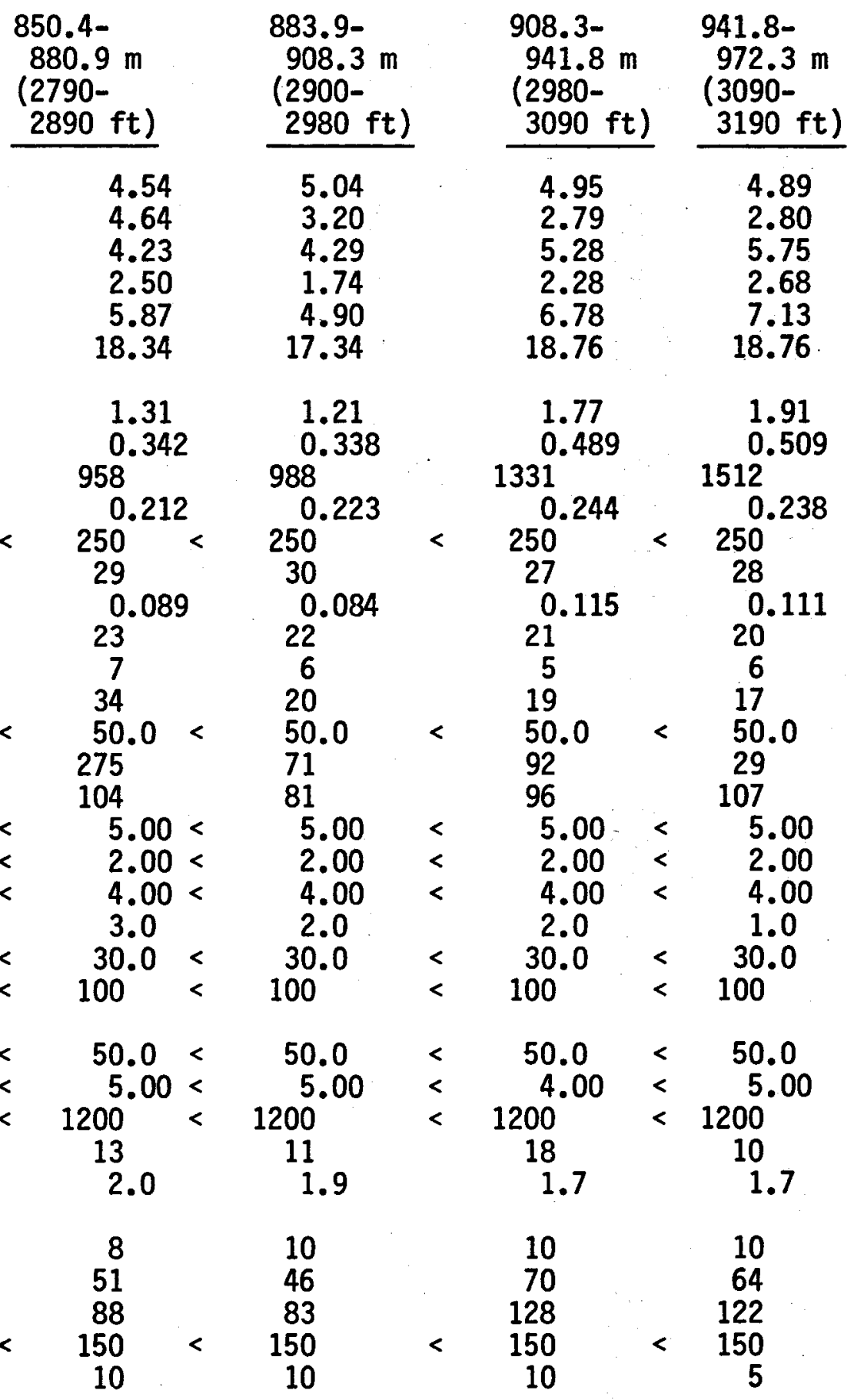


TABLE 3-I (cont.)

\begin{tabular}{cccc}
$972.3-$ & $1005.8-$ & $1036.3-$ & $1066.8-$ \\
$1005.8 \mathrm{~m}$ & $1036.3 \mathrm{~m}$ & $1066.8 \mathrm{~m}$ & $1097.3 \mathrm{~m}$ \\
$(3190-$ & $(3300-$ & $(3400-$ & $(3400-$ \\
$3300 \mathrm{ft})$ & $3400 \mathrm{ft})$ & $3500 \mathrm{ft})$ & $3600 \mathrm{ft})$ \\
\hline
\end{tabular}

\begin{tabular}{|c|c|c|c|c|c|c|c|c|c|}
\hline $\begin{array}{l}\mathrm{Na} \\
\mathrm{K} \\
\mathrm{Ca} \\
\mathrm{Mg} \\
\mathrm{Fe} \\
\mathrm{Al}\end{array}$ & $\begin{array}{ll}\% & 0 X . \\
\% & 0 X . \\
\% & 0 X . \\
\% & 0 X . \\
\% & 0 X . \\
\% & 0 X .\end{array}$ & & $\begin{array}{r}5.15 \\
3.84 \\
4.27 \\
1.71 \\
5.92 \\
17.16\end{array}$ & & $\begin{array}{r}5.47 \\
4.21 \\
4.45 \\
1.66 \\
5.82 \\
18.97\end{array}$ & & $\begin{array}{r}4.99 \\
3.23 \\
5.13 \\
2.37 \\
8.20 \\
17.11\end{array}$ & & $\begin{array}{r}5.36 \\
2.93 \\
3.30 \\
1.22 \\
4.33 \\
16.93\end{array}$ \\
\hline $\begin{array}{l}\mathrm{Ti} \\
\mathrm{p} \\
\mathrm{Sr} \\
\mathrm{Ba} \\
\mathrm{V} \\
\mathrm{Cr} \\
\mathrm{Mn} \\
\mathrm{Co} \\
\mathrm{Ni} \\
\mathrm{Cu} \\
\mathrm{Mo} \\
\mathrm{Pb} \\
\mathrm{Zn} \\
\mathrm{Cd} \\
\mathrm{Ag} \\
\mathrm{Au} \\
\mathrm{Ad} \\
\mathrm{Sb}\end{array}$ & $\begin{array}{l}\% \text { OX. } \\
\% \text { OX. } \\
\text { PPM } \\
\% \text { OX. } \\
\text { PPM } \\
\text { PPM } \\
\% \text { OX. } \\
\text { PPM } \\
\text { PPM } \\
\text { PPM } \\
\text { PPM } \\
\text { PPM } \\
\text { PPM } \\
\text { PPM } \\
\text { PPM } \\
\text { PPM } \\
\text { PPM } \\
\text { PPM } \\
\text { PPM }\end{array}$ & $\begin{array}{l}< \\
<\end{array}$ & $\begin{array}{c}1.62 \\
0.345 \\
1253 \\
0.356 \\
250 \\
26 \\
0.10 \\
18 \\
5.00 \\
13 \\
50.0 \\
35 \\
81 \\
5.00 \\
2.00 \\
4.00 \\
3.0 \\
30.0 \\
100\end{array}$ & $\begin{array}{l}9 \\
6 \\
< \\
4 \\
< \\
< \\
< \\
< \\
< \\
< \\
<\end{array}$ & $\begin{array}{c}1.59 \\
0.367 \\
1287 \\
0.328 \\
250 \\
30 \\
0.107 \\
23 \\
5 \\
18 \\
50.0 \\
37 \\
86 \\
5.00 \\
2.00 \\
4.00 \\
2.0 \\
30.0 \\
100\end{array}$ & $\begin{array}{l}< \\
<\end{array}$ & $\begin{array}{c}1.83 \\
0.545 \\
1155 \\
0.254 \\
250 \\
54 \\
0.121 \\
25 \\
19 \\
25 \\
50.0 \\
43 \\
103 \\
5.00 \\
2.00 \\
4.00 \\
2.0 \\
30.0 \\
100\end{array}$ & $\begin{array}{l}< \\
< \\
<\end{array}$ & $\begin{array}{c}1.04 \\
0.214 \\
711 \\
0.164 \\
250 \\
29 \\
0.078 \\
20 \\
6 \\
15 \\
50.0 \\
33 \\
70 \\
5.00 \\
2 \\
4.00 \\
1.0 \\
30.0 \\
100\end{array}$ \\
\hline $\begin{array}{l}\text { Te } \\
\text { Sn }\end{array}$ & $\begin{array}{l}\text { PPM } \\
\text { PPM }\end{array}$ & $<$ & $\begin{array}{c}50.0 \\
5.00\end{array}$ & $<$ & $\begin{array}{c}50.0 \\
5.00\end{array}$ & $<$ & $\begin{array}{c}50.0 \\
5.00\end{array}$ & $<$ & $\begin{array}{r}50.0 \\
5.00\end{array}$ \\
\hline $\begin{array}{l}\mathrm{Li} \\
\mathrm{Be}\end{array}$ & $\begin{array}{l}\text { PPM } \\
\text { PPM }\end{array}$ & & $\begin{array}{l}9 \\
1.4\end{array}$ & & $\begin{array}{l}8 \\
1.4\end{array}$ & & $\begin{array}{l}9 \\
1.9\end{array}$ & & $\begin{array}{l}6 \\
1.2\end{array}$ \\
\hline $\begin{array}{l}\mathrm{Zr} \\
\mathrm{La} \\
\mathrm{Ce} \\
\mathrm{Th}\end{array}$ & $\begin{array}{l}\text { PPM } \\
\text { PPM } \\
\text { PPM } \\
\text { PPM } \\
\text { PPB }\end{array}$ & $<$ & $\begin{array}{r}11 \\
50 \\
93 \\
150 \\
5\end{array}$ & $<$ & $\begin{array}{r}11 \\
63 \\
111 \\
150 \\
5\end{array}$ & $<$ & $\begin{array}{r}40 \\
68 \\
127 \\
150 \\
5\end{array}$ & $\begin{array}{l}< \\
<\end{array}$ & $\begin{array}{r}12 \\
57 \\
98 \\
150 \\
5\end{array}$ \\
\hline
\end{tabular}


TABLE 3-I (cont.)

ELEMENT

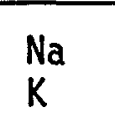

$\mathrm{Ca}$

$\mathrm{Mg}$

$\mathrm{Fe}$

A1

Ti

$P$

Sr

$\mathrm{Ba}$

$V$

$\mathrm{Cr}$

$\mathrm{Mn}$

Co

$\mathrm{Ni}$

$\mathrm{Cu}$

Mo

$\mathrm{Pb}$

$\mathrm{Zn}$

$\mathrm{Cd}$

$\mathrm{Ag}$

Au

As

$\mathrm{Sb}$

Bi

Te

Sn

Li

$\mathrm{Be}$

$\mathrm{Zr}$

La

Ce

Th

$\mathrm{Hg}$
\% OX.

$\%$ OX.

$\%$ OX.

$\%$ OX.

$\%$ ox.

$\%$ OX.

$\%$ OX.

$\%$ OX.

PPM

$\%$ OX.

PPM

$\%$ OX.

PPM

PPM

PPM

PPM

PPM

PPM

PPM

PPM

PPM

PPM

PPM

PPM <
112.7 .8

$1097.3-$
$1127.8 \mathrm{~m}$

$3700 \mathrm{ft}$ )

5.52

3.82

1.88

0.524

2.13

16.56

$$
0.539
$$

0.087

292

$<\quad 250^{0.074}<250^{0.073}$

21

0.049

13

$5.00<$

8

50.0

21

46

5.00

$2.00<$
$4.00<$

1.0

30.0

100

$50.0<50.0<$
$5.00<5.00<$

(3700-

$3800 \mathrm{ft}$ )

5.41

3.65

1.91

0.552

3.37

15.99

34

0.065

16

0.877

0.133

5.00

12

50.0

25

51

5.00

2.00

4.00

2.0

30.0

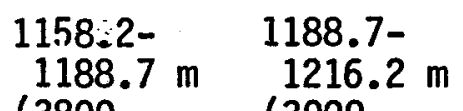

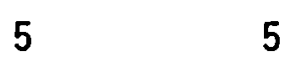

0.8
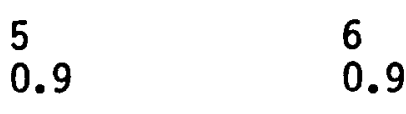

6
0.9

0.9

$\begin{array}{rr}11 & 19 \\ 48 & 89 \\ 79 & \quad 150 \\ 150 & < \\ 5 & 5\end{array}$

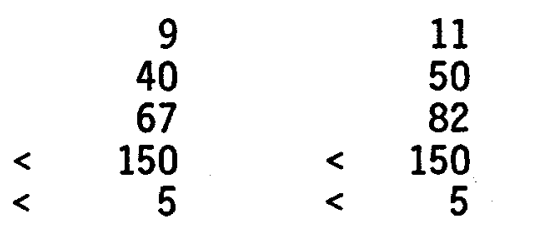


ELEMENT

$\mathrm{Na}$

$\mathrm{K}$

$\mathrm{Ca}$

$\mathrm{Mg}$

Fe

Al

Ti

$P$

$\mathrm{Sr}$

$\mathrm{Ba}$

$\checkmark$

$\mathrm{Cr}$

$\mathrm{Mn}$

Co

$\mathrm{Ni}$

$\mathrm{Cu}$

Mo

$\mathrm{Zn}$

Cd

$\mathrm{Ag}$

$\mathrm{Au}$

As

$\mathrm{Sb}$

$\mathrm{Bi}$

Te

Sn

Li

$\mathrm{Zr}$

La

Ce

Th

TABLE 3-I (cont.)

\begin{tabular}{|c|c|c|c|}
\hline $\begin{array}{c}1216.2- \\
1246.6 \mathrm{~m} \\
(3990- \\
4090 \mathrm{ft}) \\
\end{array}$ & $\begin{array}{c}1246.6- \\
1277.1 \mathrm{~m} \\
(4090- \\
4190 \mathrm{ft}) \\
\end{array}$ & $\begin{array}{l}1277.1- \\
1307.6 \mathrm{~m} \\
(4190- \\
4290 \mathrm{ft}) \\
\end{array}$ & $\begin{array}{c}1307.6- \\
1338.1 \mathrm{~m} \\
(4290- \\
4390 \mathrm{ft}) \\
\end{array}$ \\
\hline $\begin{array}{c}5.19 \\
4.76 \\
1.94 \\
0.633 \\
2.71 \\
16.32\end{array}$ & $\begin{array}{r}5.08 \\
2.44 \\
3.75 \\
1.57 \\
4.58 \\
16.08\end{array}$ & $\begin{array}{r}5.18 \\
3.16 \\
3.46 \\
1.35 \\
4.33 \\
16.64\end{array}$ & $\begin{array}{r}5.47 \\
2.85 \\
4.01 \\
1.51 \\
4.41 \\
18.40\end{array}$ \\
\hline
\end{tabular}

$\%$ ox

$\%$ OX.

PPM

$\%$ OX.

PPM

PPM

\% OX.

PPM

PPM

PPM

PPM

PPM

PPM < $5.00<$

0.713

0.115

348

$0.108 \quad 0.273$

32

0.062

48

5.00

$$
9
$$

$50.0<$

28

60

PPM

PPM

PPM
PPM

$$
\begin{aligned}
& 5.00< \\
& 2.00<
\end{aligned}
$$

$\begin{array}{cc}1.18 & 1.17 \\ 0.273 & 0.255 \\ 1077 & 1054\end{array}$

1.15

$<.00<$
$<\quad 4.00<$

0.090

0.293

1157

0.297

2.0

15

$5.00<$

$10.00<50.0$

$50.0<$

19

$<\quad 50.0$

89

$5.00<5.00<5.00$

$2.00<2.00<2.00$

$4.00<$

$4.00<$

4.00

$1.0 \quad 1.0<1.0$

$30.0<30.0<30.0$

$30.0<$
$<100$

100

PPM $<50.0<$
PPM $<5.00<$

50.0
5.00

$<100$

$<100$

PPM

6

1.0

9
1.4

$50.0<$

50.0

PPM

11

PPM

PPM

61

PPM
PPM

PPB

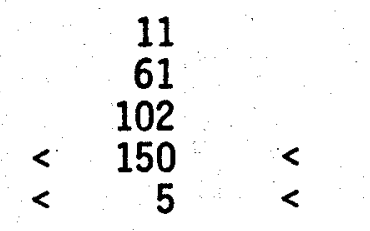

8
46
77
150
5

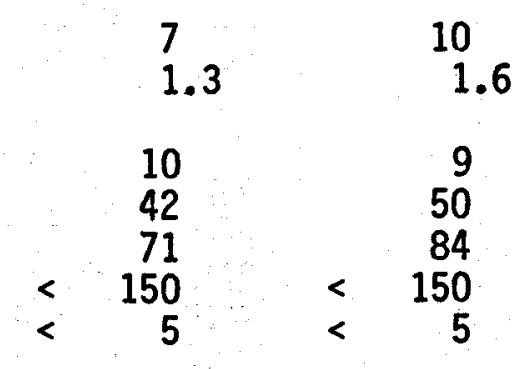


ELEMENT

$\mathrm{Na} \quad \%$ ox.

$\mathrm{K} \quad \%$ OX.

$\mathrm{Ca} \quad \%$ OX.

$\mathrm{Mg} \quad \%$ OX.

$\mathrm{Fe} \quad \% 0 \mathrm{OX}$.

Al $\%$ OX.

$\mathrm{Ti}$

$P$

$\mathrm{Sr}$

$\mathrm{Ba}$

$\mathrm{Cr}$

Mn

Co

$\mathrm{Ni}$

$\mathrm{Cu}$

Mo

$\mathrm{Pb}$

$\mathrm{Zn}$

Cd

$\mathrm{Ag}$

$\mathrm{Au}$

As

Sb

Bi

Te

Sn

W

Li

$\mathrm{Be}$

$\mathrm{Zr}$

La

Th

$\mathrm{Hg}$
$\%$ ox.

$\%$ OX.

PPM

$\%$ OX.

PPM

PPM
$\%$ OX

PPM

PPM

PPM

PPM

PPM

PPM

PPM

PPM

PPM

PPII

PPM

PPM

PPM

PPM

PPM

PPM

PPM

PPM

PPM

PPM

PPM

PPB

TABLE 3-I (cont.)

\begin{tabular}{llll}
$1338.1-$ & $1368.6-$ & $1399.0-$ & $1429.5-$ \\
$1368.6 \mathrm{~m}$ & $1399 \mathrm{~m}$ & $1429.5 \mathrm{~m}$ & $1460.0 \mathrm{~m}$ \\
$(4390-$ & $(4490-$ & $(4590-$ & $(4690-$ \\
$4490 \mathrm{ft})$ & $4590 \mathrm{ft})$ & $4690 \mathrm{ft})$ & $4790 \mathrm{ft})$ \\
\hline
\end{tabular}

5.39

2.89

3.73

1.27

4.48

17.09

1.25

0.303

1143

0.324

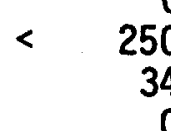

0.091

30
$<\quad 5.00<$

10

$<$

50.0

22

73

$<\quad 5.00<$

$<\quad 2.00<$

$<\quad 4.00<$

$5.0<$
$<\quad 30.0<$

$<100$

5.50

4.15

4.16

1.63

4.88

18.10

5.34

3.02

3.66

1.72

4.44

18.27

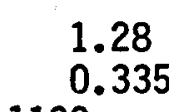

1130

0.289

250

32

0.093

.21

5.00

12

50.0
258

83

5.00

$$
2.00
$$

4.00

1.0

30.0

100

$<50.0<$
$<\quad 5.00<$

1200
9

9
1.5

50.0

5.00

1200

9

10
44
75

75

75
$\quad 50$

\section{0}

56

92
150

5
1180

0.092

85

5.00
1.4

10
1.5

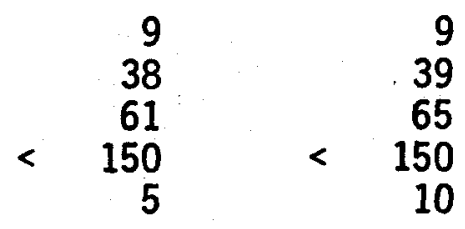

5.07

3.18

3.38

1.35

4.12

16.74

1044

1.08

0.221

0.323

34

0.086

19

5

10

50.0

45

68

$$
\begin{array}{r}
5.00 \\
<\quad 2.00
\end{array}
$$$$
<\quad 4.00
$$

$4.00<1.0$
$<\quad 30.0<30.0$

$<100<100$

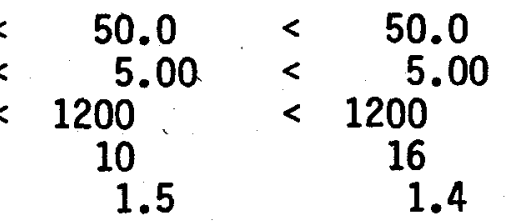


TABLE 3-I (cont.)

\section{ELEMENTS}

$\mathrm{Na}$

$\mathrm{K}$

$\mathrm{Mg}$

$\mathrm{Fe}$

A1

Ti

$P$

$\mathrm{Sr}$

$\mathrm{Ba}$

$\mathrm{Cr}$

$\mathrm{Cr}$

$\mathrm{Mn}$
$\mathrm{Co}$

$\mathrm{Ni}$

$\mathrm{Cu}$

Mo

$\mathrm{Pb}$

$\mathrm{Zn}$

Cd.

$\mathrm{Ag}$

$\mathrm{Au}$

As

$\mathrm{Sb}$

$\mathrm{Bi}$

$\mathrm{Te}$

$\mathrm{Li}$

$\mathrm{Zr}$

La

$\mathrm{Ce}$

Th

$\mathrm{Hg}$
$\%$ ox.

$\%$ OX.

$\%$ ox.

$\%$ ox.

$\%$ ox.

$\%$ OX.

$\%$ ox.

$\%$ OX.

PPM

$\%$ OX.

PPM

\% OX.

PPM

PPM

PPM

PPM

PPM

PPM

PPM
PPM

PPM
PPM

PPM

PPM

PPM

PPM

PPM

PPM

PPM

PPM

PPM

PPM

PPB

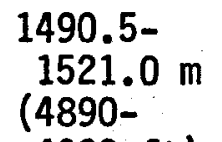

$4990 \mathrm{ft}$ )

17.58

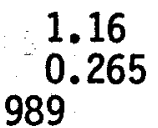

0.331

250

31

0.090

18

$5.00<$

90

31

70

$5.00<$

$2.00<$

4.00

1.0

30.0

$50.0<$

8

1.3

12

47

78

150

\subsection{3}

3.21

3.28

1.25

4.22

17.84

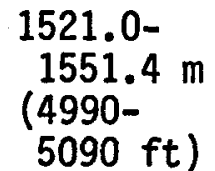

5.21

3.08

3.05

1.15

3.58

16.86

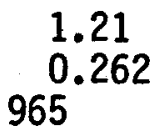

0.339

250

34

0.091

20

5.00

9

50.00

25

66

$$
5.00
$$

2.00

4.00

1.0

30.0

100

50.0

\section{7}

1.2

13

49

81

150
1551.4-

$1581.9 \mathrm{~m}$

(5090-

$5190 \mathrm{ft}$ ) 


\section{ELEMENT}

$\mathrm{Na} \quad \%$ OX.

$\mathrm{K} \quad \%$ OX.

$\mathrm{Ca} \quad \%$ OX.

$\mathrm{Mg} \%$ oX.

$\mathrm{Fe} \quad \% 0 \mathrm{OX}$.

A1 $\%$ OX.

$\mathrm{Ti} \quad \%$ OX.

$\mathrm{P} \quad \% \mathrm{OX}$.

Sr $\quad$ PPM

$\mathrm{Ba} \quad \%$ OX.

$\checkmark$

$\mathrm{Cr}$

$\mathrm{Mn}$

Co

$\mathrm{Ni}$

$\mathrm{Cu}$

Mo

$\mathrm{Pb}$

$\mathrm{Zn}$

$\mathrm{Cd}$

$\mathrm{Ag}$

$\mathrm{Au}$

As

Sb

$\mathrm{Bi}$

$\mathrm{Te}$

$\mathrm{Sn}$

Li

$\mathrm{Be}$

$\mathrm{Zr}$

$\mathrm{Ce}$

Th

$\mathrm{Hg}$

PPM

$\%$ OX.

PPM

PPM

PPM

PPM

PPM

PPM

PPM

PPM

PPM

PPM

PPM

PPM

PPM

PPM

PPM

PPM

PPM

PPM

PPM

PPM

PPB

TABLE 3-I (cont.)

\begin{tabular}{llll}
$1581.9-$ & $1612.4-$ & $1642.9-$ & $1673.4-$ \\
$1612.4 \mathrm{~m}$ & $1642.9 \mathrm{~m}$ & $1673.4 \mathrm{~m}$ & $1703.8 \mathrm{~m}$ \\
$(5190-$ & $(5290-$ & $(5390-$ & $(5490-$ \\
$5290 \mathrm{ft})$ & $5390 \mathrm{ft})$ & $54.90 \mathrm{ft})$ & $5590 \mathrm{ft})$ \\
\hline
\end{tabular}

5.30

3.85

3.35

1.21

4.92

16.78

1.31

0.322

886

0.093

18

11

35

65

100

7
1.3

16

51

84

$<\quad 150$

10
5.03

3.99

2.95

1.10

4.82

15.93

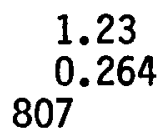

0.294

250

30

0.088

$<\quad 5.00<$

$50.0<$

$5.00<$

$2.00<$

$4.00<$

$1.0<$

$30.0<$

$50.0<$

21

6

12

50.0

45

66

5.00

$$
2.00
$$

4.00

1.0

30.0

100

7

1.3

16

53

86

150

10
5.11

3.91

2.72

1.12

4.10

16.26

5.13

4.03

2.88

1.27

4.13

17.07

50.0 <

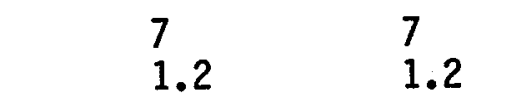

$\begin{array}{rr}14 & 15 \\ 39 & 38 \\ 62 & 63 \\ 150 & 150 \\ 5 & 5\end{array}$


ELEMENTS

$\mathrm{Na} \quad \%$ OX.

$\mathrm{K} \quad \%$ OX.

$\mathrm{Ca} \%$ OX.

$\mathrm{Mg} \quad \%$ OX.

$\mathrm{Fe} \quad \% 0 \mathrm{OX}$.

A1 $\%$ oX.

Ti $\%$ ox.

$P \quad \%$ OX.

Sr $\quad$ PPM

$\mathrm{Ba} \%$ OX.

$v$ PPM

Cr PPM

Mn \% OX.

Co PPM

$\mathrm{Ni} \quad \mathrm{PPM}$

$\mathrm{Cu} \quad \mathrm{PPM}$

Mo

$\mathrm{Pb}$

Zn

Cd

$\mathrm{Ag}$

$\mathrm{Au}$

As

$\mathrm{Sb}$

Bi

Te

Sn

Li

Be

$\mathrm{Zr}$

$\mathrm{Ce}$.

Th

$\mathrm{Hg}$

TABLE 3-I (cont.)

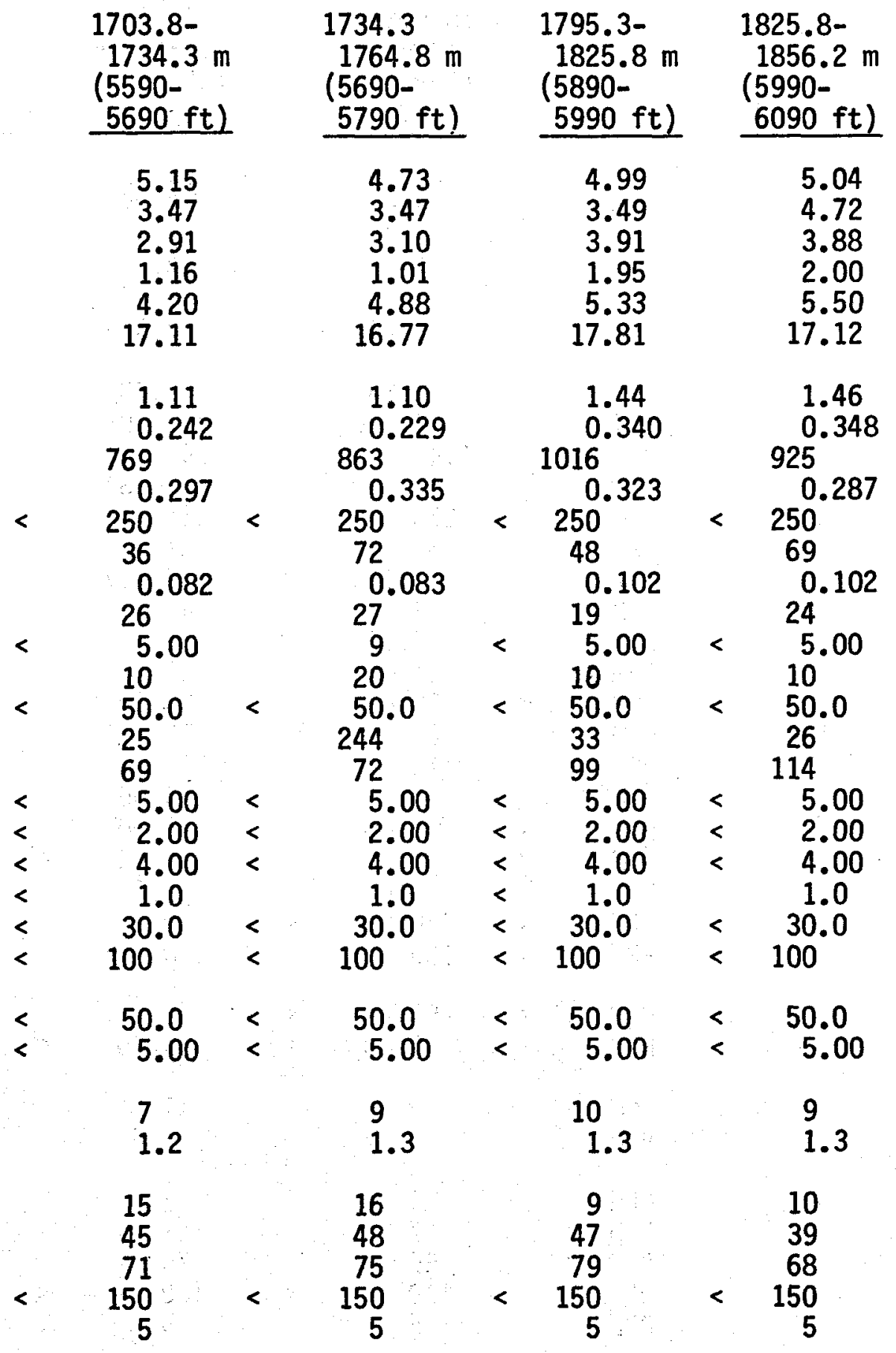


TABLE 3-I (cont.)

ELEMENT

$\mathrm{Na} \quad \%$ ox.

$\mathrm{K} \quad \%$ OX.

$\mathrm{Ca} \quad \% 0 \mathrm{OX}$.

$\mathrm{Mg} \quad \%$ OX.

$\mathrm{Fe} \quad \% 0 \mathrm{OX}$.

Al $\quad \%$ OX.

$\mathrm{Ti}$ \% OX.

P \% OX.

$\mathrm{Sr} \quad \mathrm{PPM}$

$\mathrm{Ba} \quad \%$ OX.

$\mathrm{V}$

$\mathrm{Cr}$

Mn

Co

$\mathrm{Ni}$

$\mathrm{Cu}$

Mo

$\mathrm{Pb}$

$\mathrm{Zn}$

Cd

$\mathrm{Ag}$

$\mathrm{Au}$

As

Sb

Bi

$\mathrm{Te}$

Sn

Li

$\mathrm{Be}$

$\mathrm{Zr}$

La

Ce

Th

$\mathrm{Hg}$
PPM

PPM

$\%$ OX.

PPM

PPM

PPM

PPM

PPM

PPM

PPM

PPM

PPM

PPM

PPM

PPM <
PPM

PPM

PPM

PPM

PPM

PPM

PPM

PPB

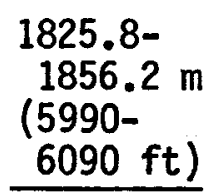

5.25

3.00

4.30

2.38

5.93

19.21

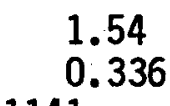

1141

0.378

250
61
0.109

32

5.00

11

$50.0<$

$$
22
$$

119

5.00

$2.00<$

$2.00<$

4.00

1.0

30.0

100

50.0 <

9

1.4

9
47

69

150

5

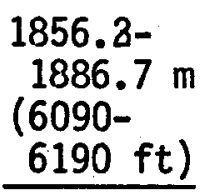

5.01

3.09

4.43

2.89

6.99

18.51

$$
\begin{gathered}
1.60 \\
0.303
\end{gathered}
$$

1197

0.334

250

81

0.117

44

8

13

50.0

$$
20
$$

137

5.00

$$
2.00
$$

$$
2.00
$$$$
4.00
$$

1.0

30.0

100

$50.0<$
$5.00<$

$1886.7-$
$1917.2 \mathrm{~m}$
$(6190-$

$6290 \mathrm{ft}$ )

4.44

3.07

6.35

4.15

9.16

18.48

1917.2-

$1947.7 \mathrm{~m}$

(6290-

$6390 \mathrm{ft}$ ) 
TABLE 3-I (cont.)

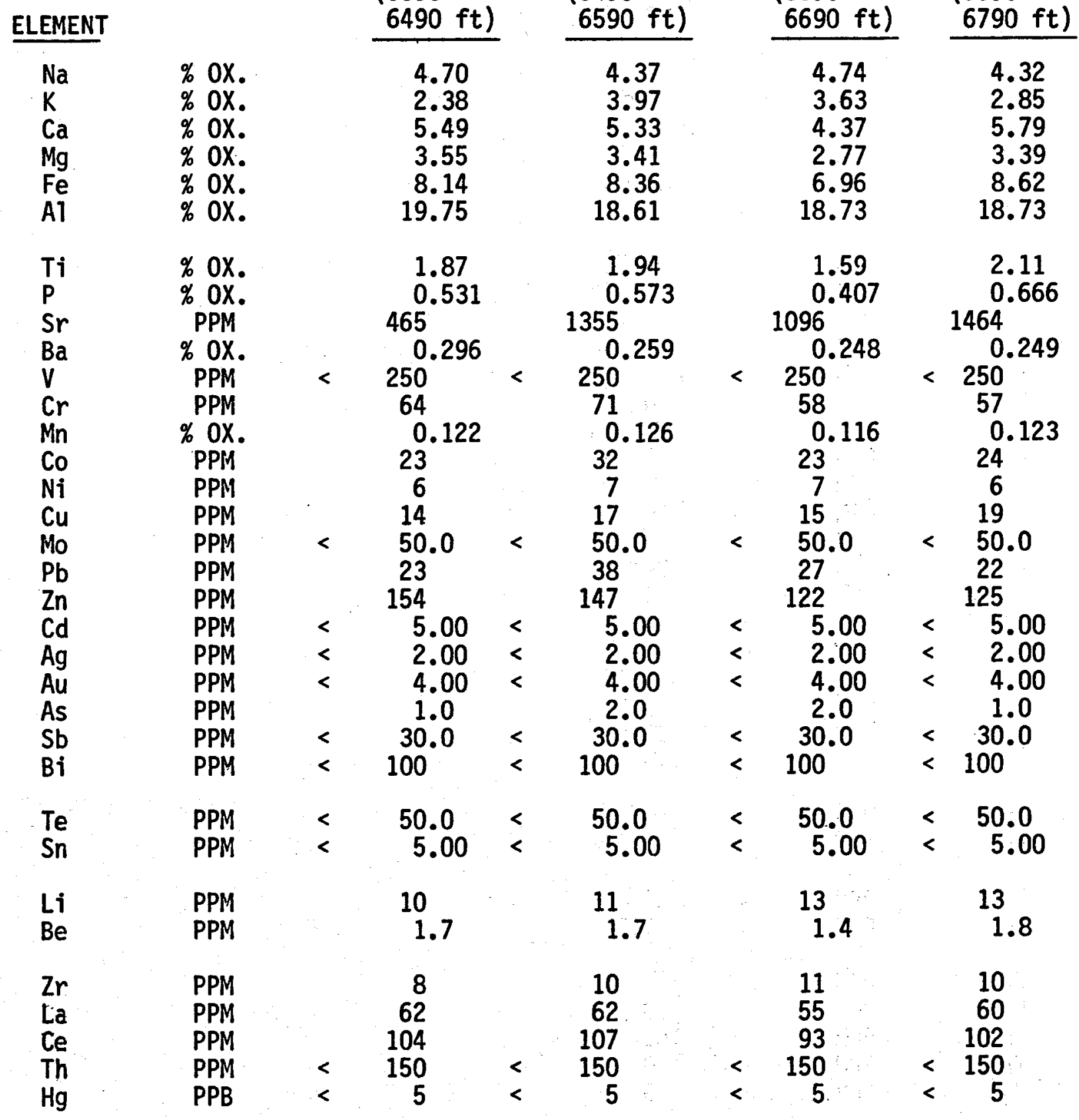


TABLE 3-I (cont.)

\section{ELEMENT}

2069.6-

$2095.8 \mathrm{~m}$

(6790-

$6885 \mathrm{ft})$

\begin{tabular}{|c|c|c|c|}
\hline $\begin{array}{l}\mathrm{Na} \\
\mathrm{K} \\
\mathrm{Ca} \\
\mathrm{Mg} \\
\mathrm{Fe} \\
\mathrm{Al}\end{array}$ & $\begin{array}{ll}\% & 0 X . \\
\% & 0 X . \\
\% & 0 X . \\
\% & 0 X . \\
\% & 0 X . \\
\% & 0 X .\end{array}$ & & $\begin{array}{r}4.31 \\
4.16 \\
4.81 \\
3.14 \\
7.60 \\
18.07\end{array}$ \\
\hline $\begin{array}{l}\mathrm{Ti} \\
\mathrm{P} \\
\mathrm{Sr} \\
\mathrm{Ba} \\
\mathrm{V} \\
\mathrm{Cr} \\
\mathrm{Mn} \\
\mathrm{Co} \\
\mathrm{Ni} \\
\mathrm{Cu} \\
\mathrm{Mo} \\
\mathrm{Pb} \\
\mathrm{Zn} \\
\mathrm{Cd} \\
\mathrm{Ag} \\
\mathrm{Au} \\
\mathrm{As} \\
\mathrm{Sb} \\
\mathrm{Bi}\end{array}$ & $\begin{array}{l}\% \text { OX. } \\
\% \text { OX. } \\
\text { PPM } \\
\% \text { OX. } \\
\text { PPM } \\
\text { PPM } \\
\% \text { OX. } \\
\text { PPM } \\
\text { PPM } \\
\text { PPM } \\
\text { PPM } \\
\text { PPM } \\
\text { PPM } \\
\text { PPM } \\
\text { PPM } \\
\text { PPM } \\
\text { PPM } \\
\text { PPM } \\
\text { PPM }\end{array}$ & $\begin{array}{l}< \\
< \\
<\end{array}$ & $\begin{array}{c}1.72 \\
0.523 \\
1147 \\
0.256 \\
250 \\
60 \\
0.118 \\
25 \\
7 \\
16 \\
50.0 \\
39 \\
125 \\
5.00 \\
2.00 \\
4.00 \\
2.0 \\
30.0 \\
100\end{array}$ \\
\hline $\begin{array}{l}\text { Te } \\
\text { Sn }\end{array}$ & $\begin{array}{l}\text { PPM } \\
\text { PPM }\end{array}$ & $<$ & $\begin{array}{c}50.0 \\
5.00\end{array}$ \\
\hline $\begin{array}{l}\mathrm{Li} \\
\mathrm{Be}\end{array}$ & $\begin{array}{l}\text { PPM } \\
\text { PPM }\end{array}$ & $<$ & $\begin{array}{l}13 \\
1.8\end{array}$ \\
\hline $\begin{array}{l}\mathrm{Zr} \\
\mathrm{La} \\
\mathrm{Ce} \\
\mathrm{Th} \\
\mathrm{Hg}\end{array}$ & $\begin{array}{l}\text { PPM } \\
\text { PPM } \\
\text { PPM } \\
\text { PPM } \\
\text { PPB }\end{array}$ & $<$ & $\begin{array}{r}10 \\
60 \\
102 \\
150 \\
5\end{array}$ \\
\hline
\end{tabular}




\section{$\mathrm{C} / \mathrm{T}-2$}

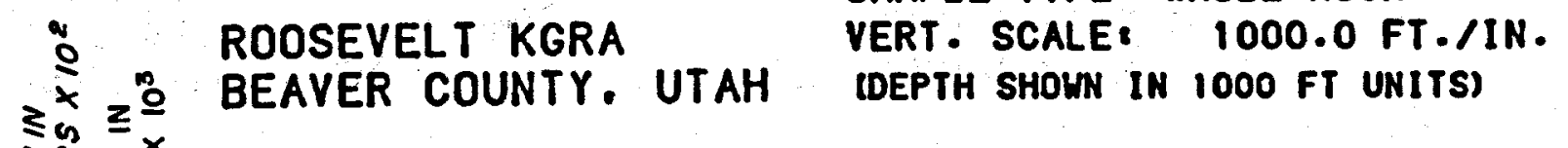

$\leqslant \sin x$

发政

点

岁岁崖 100000.
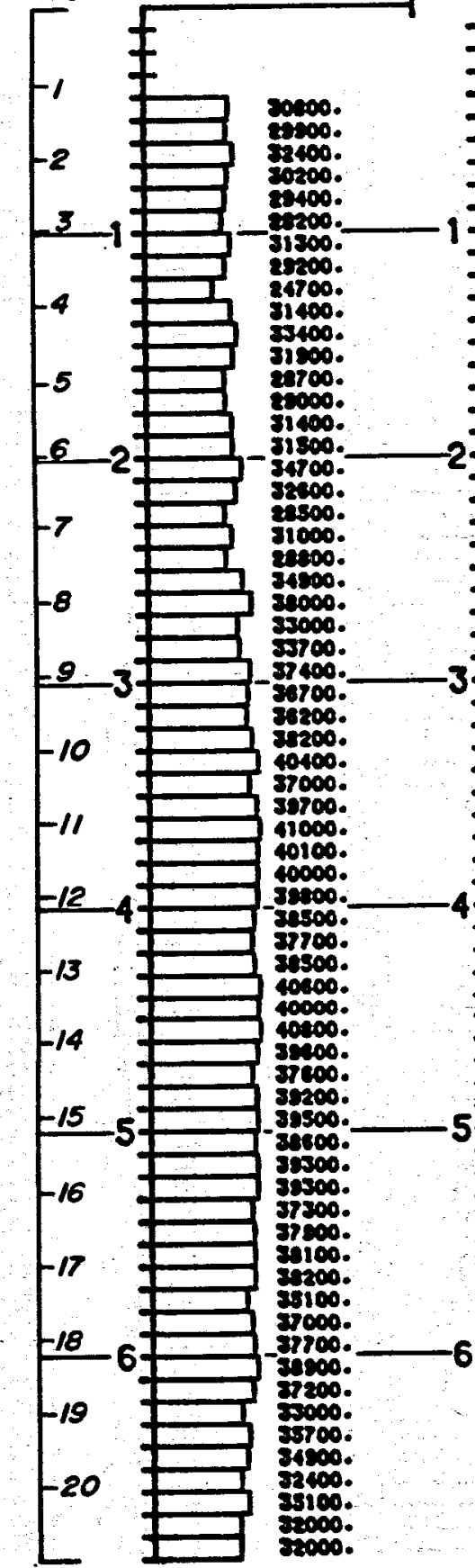

(2500.

32000.

20000.

35700 .

3400.

25100.

inose.

Fig. 3-1.

of Well C/T-2 as a function of depth.
PPM MG

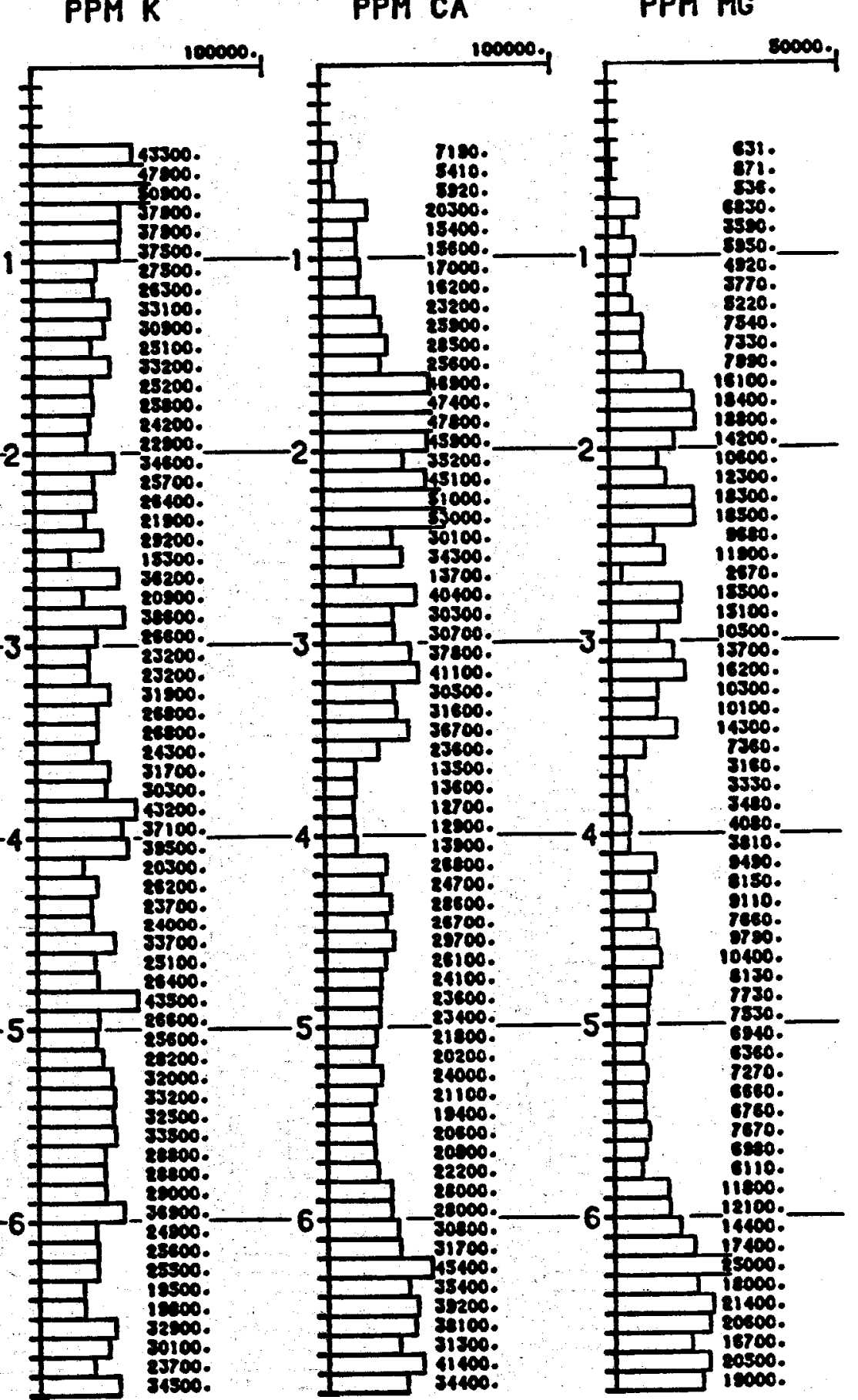


C/T-2

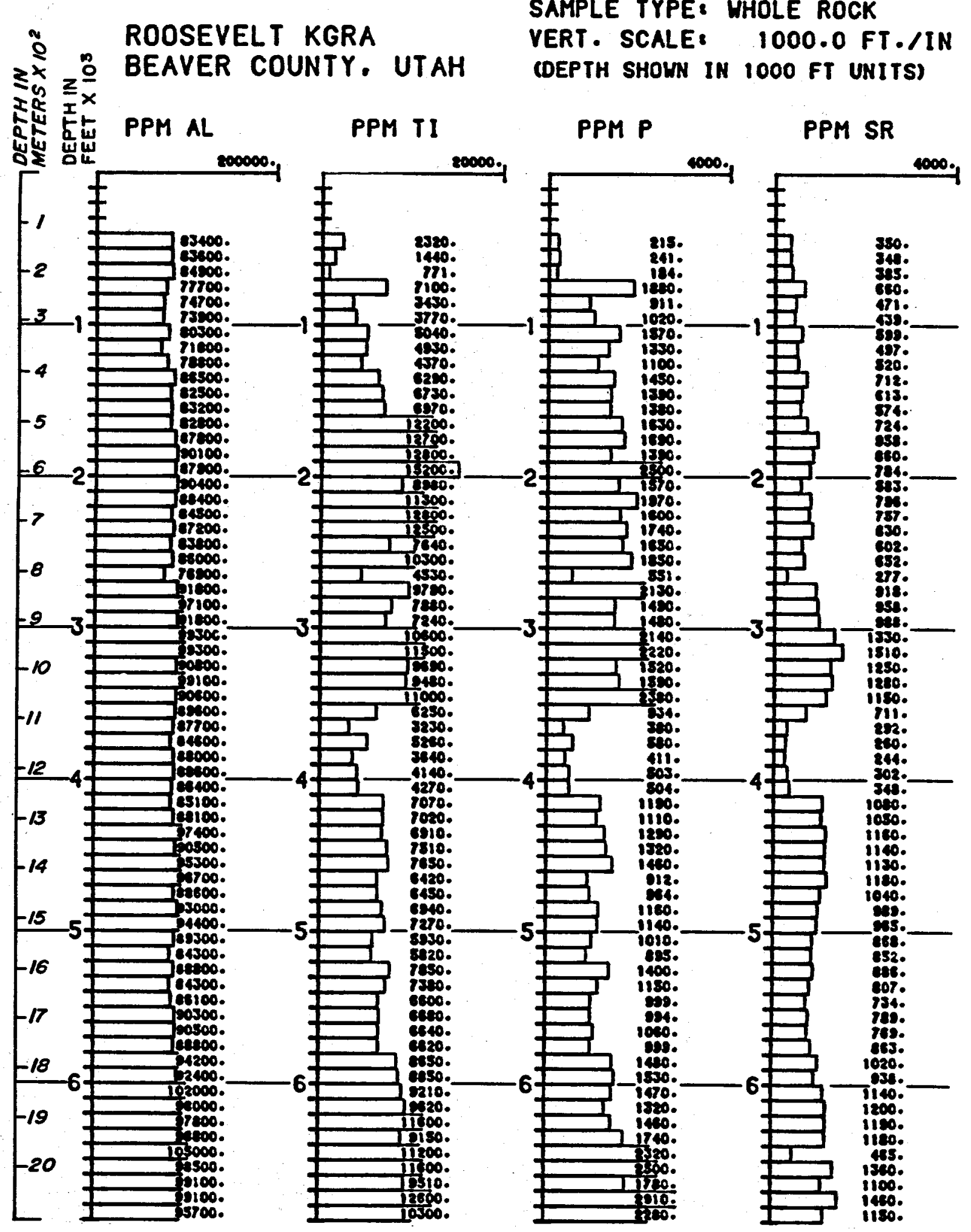

Fig. 3-1. (cont.) 
$\mathrm{C} / \mathrm{T}-2$

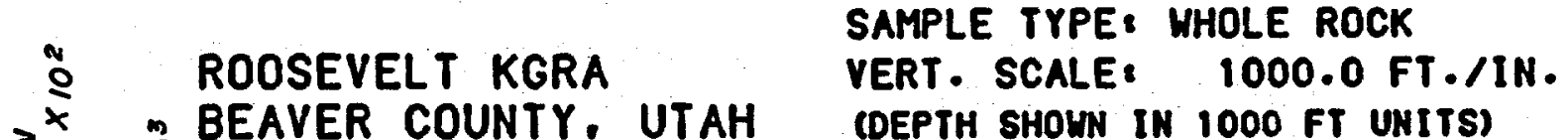
$\leq 0 \leq 0$ BEAVER COUNTY. UTAH

空悉

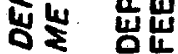

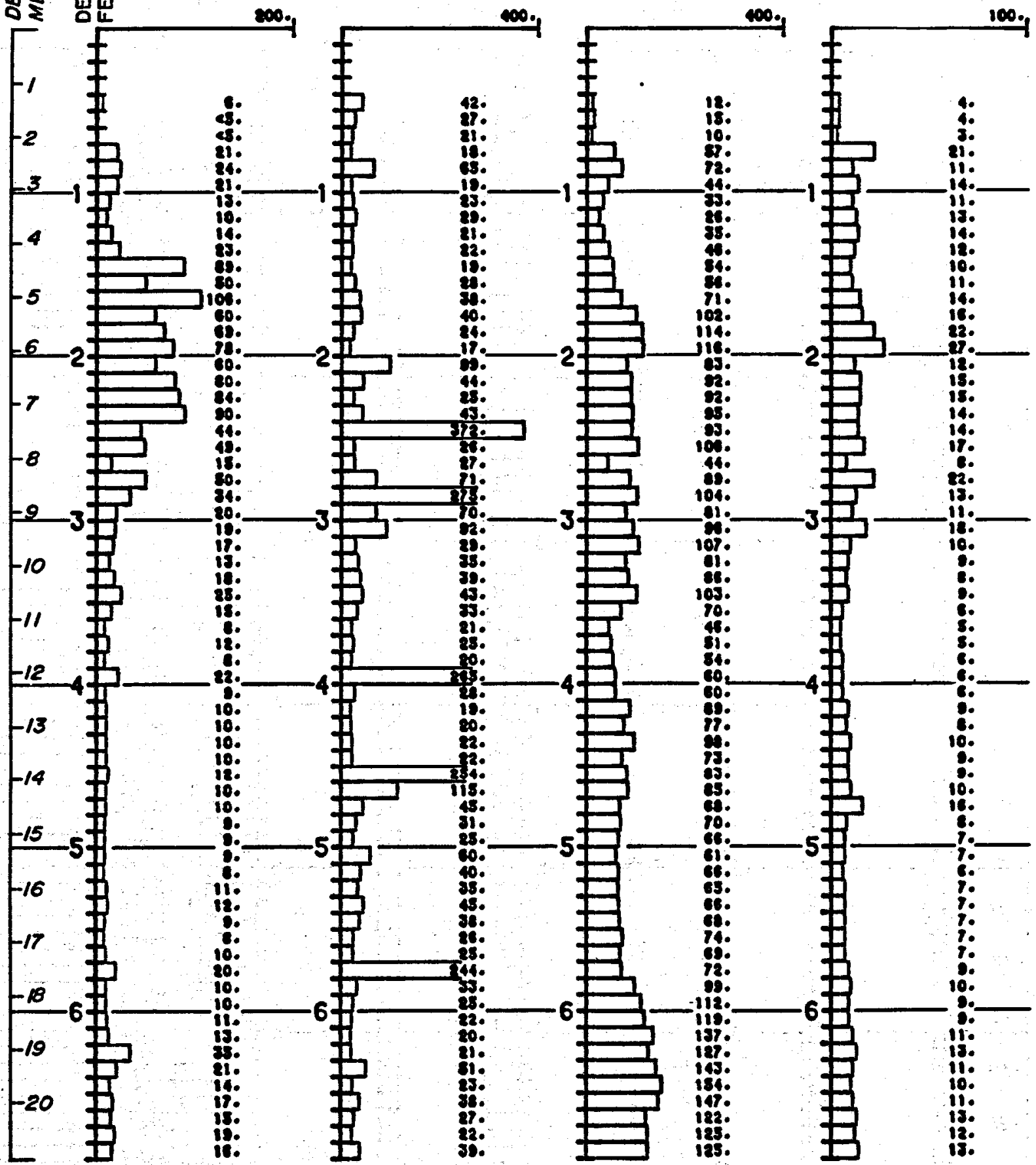

Fig. 3-1. (cont.) 
$\mathrm{C} / \mathrm{T}-2$

\&े ROOSEVELT KGRA

Z $z \stackrel{\square}{*}$ BEAVER COUNTY, UTAH

PPM NI PPM BE

1004
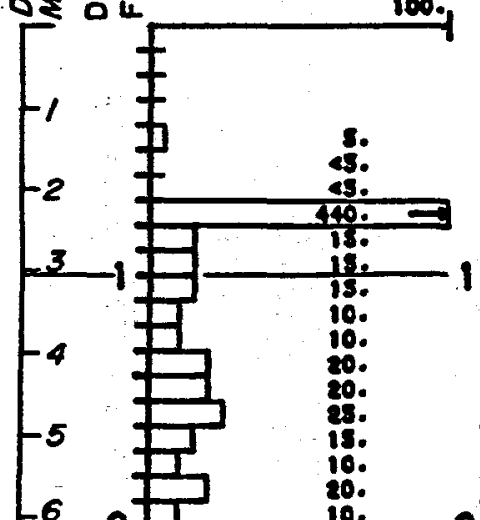

-6
-8
-8
-3
-3
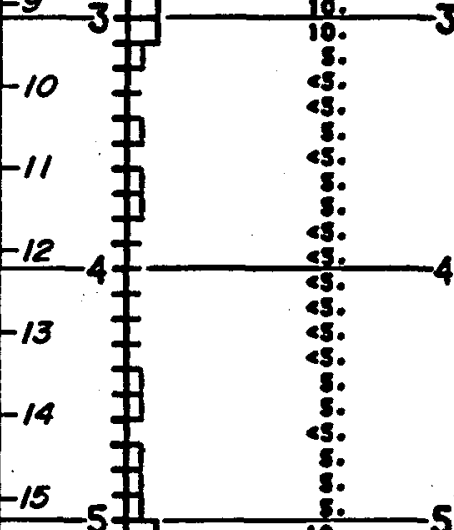

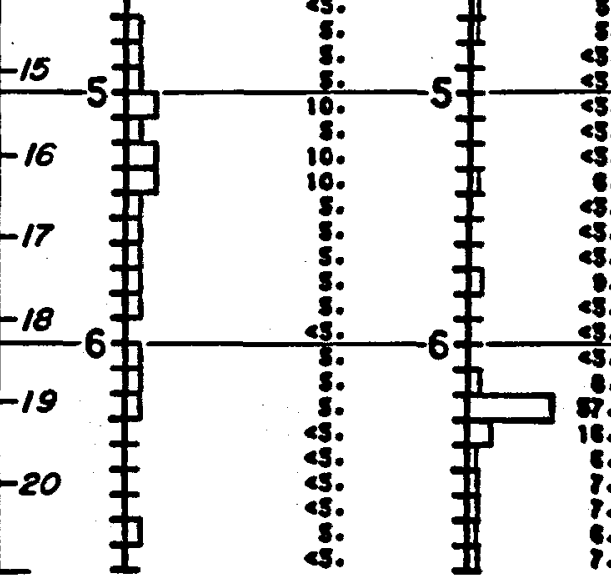

SAMPLE TYPE: WHOLE ROCK

VERT. SCALE: $\quad 1000.0$ FT. /IN

(DEPTH SHOWN IN 1000 FT UNITS)

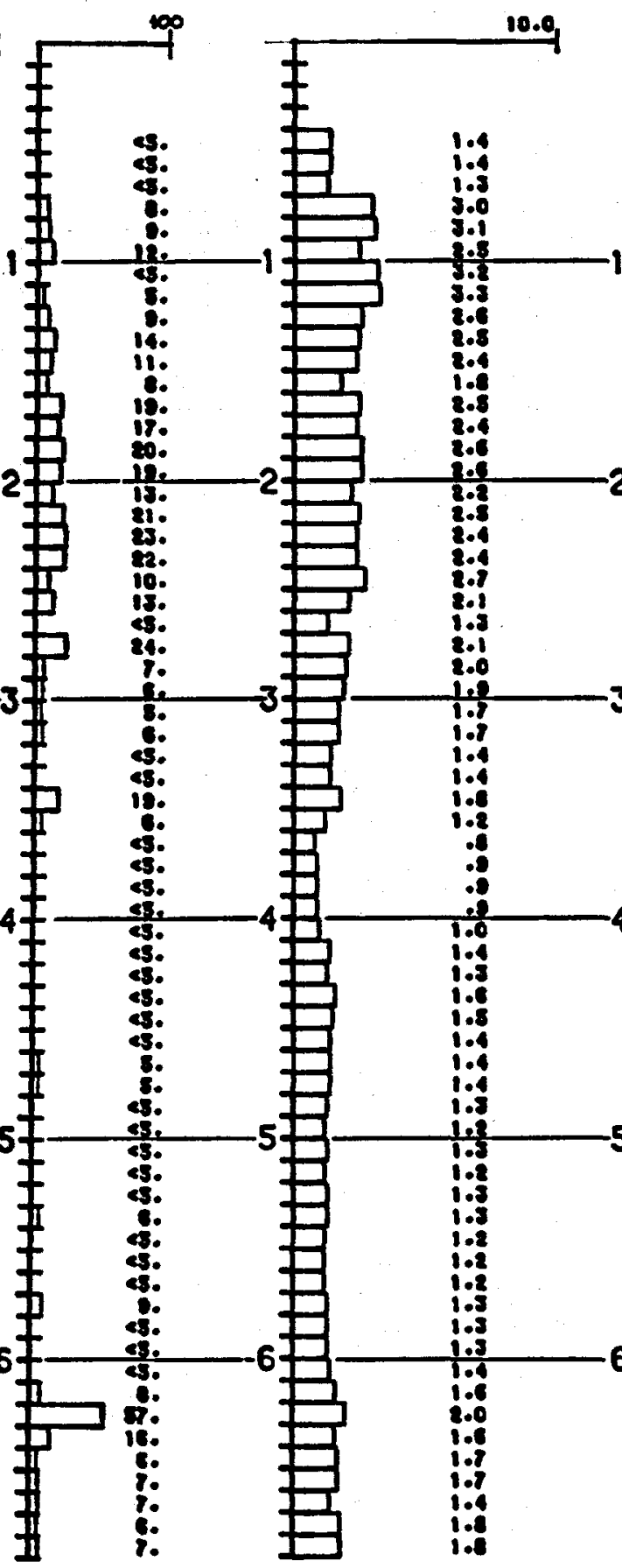

PPM FE

PPM BA

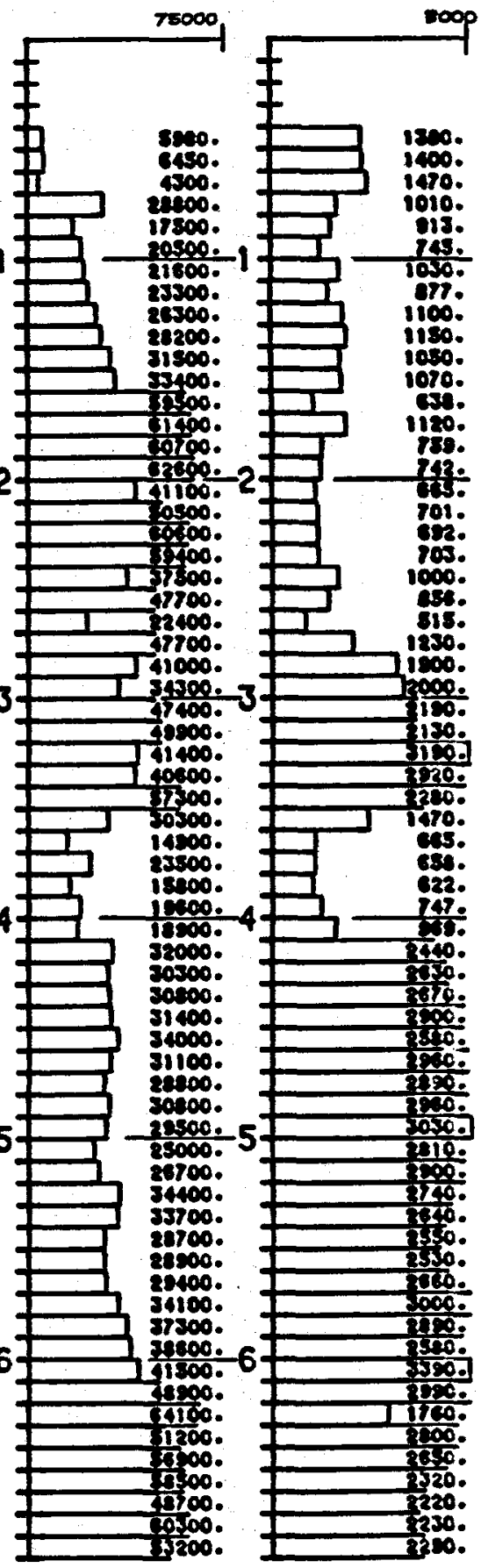

Fig. 3-1. (cont.) 


\section{C/T-2}

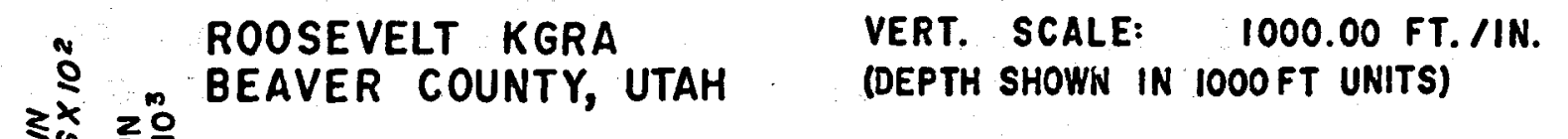

SAMPLE TYPE: WHOLE ROCK

VERT, SCALE: 1000.00 FT. IIN.

(DEPTH SHOWN IN 1000 FT UNITS)

PPM CE

PPM AS*

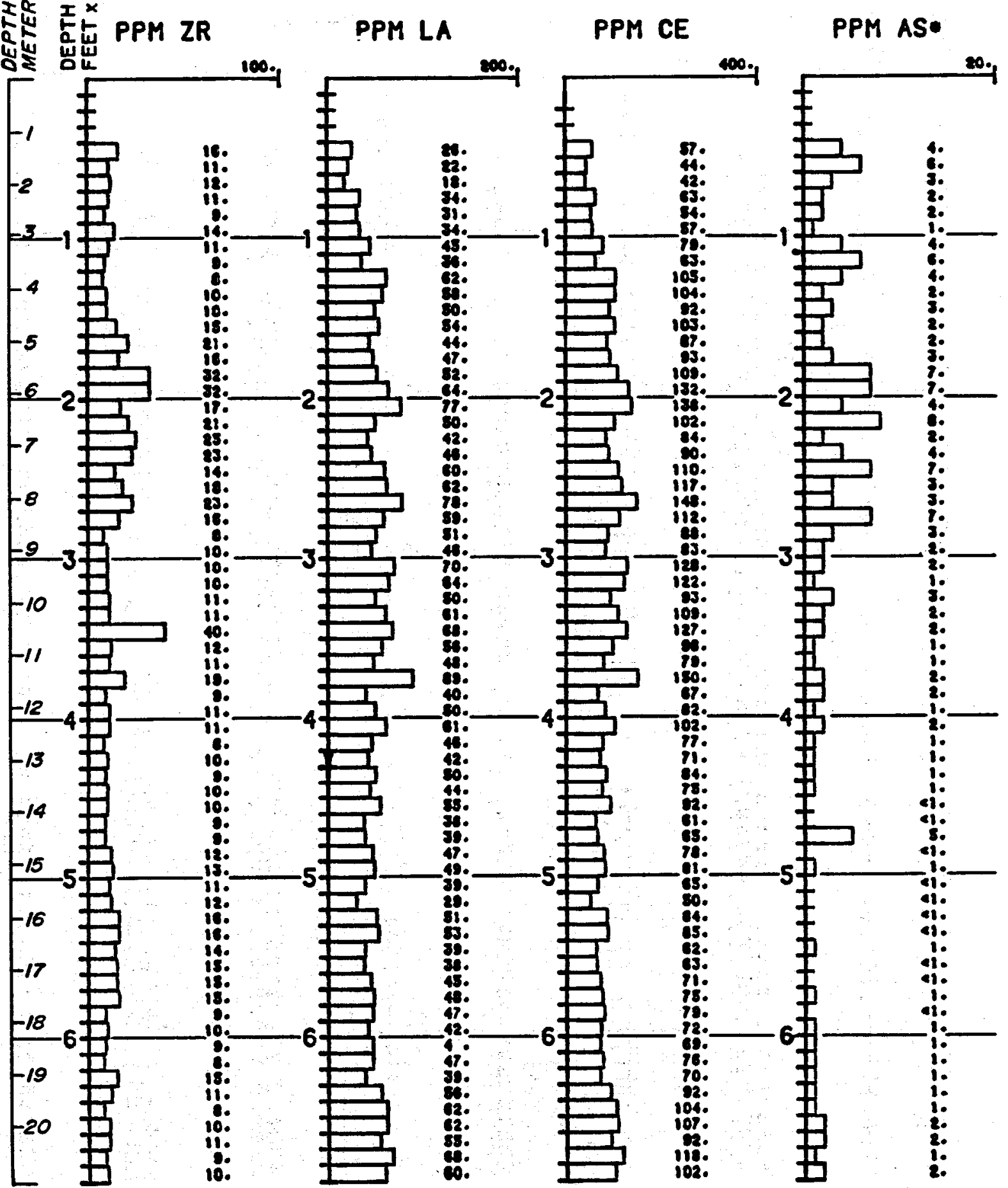

Fig. 3-1. (cont.) 


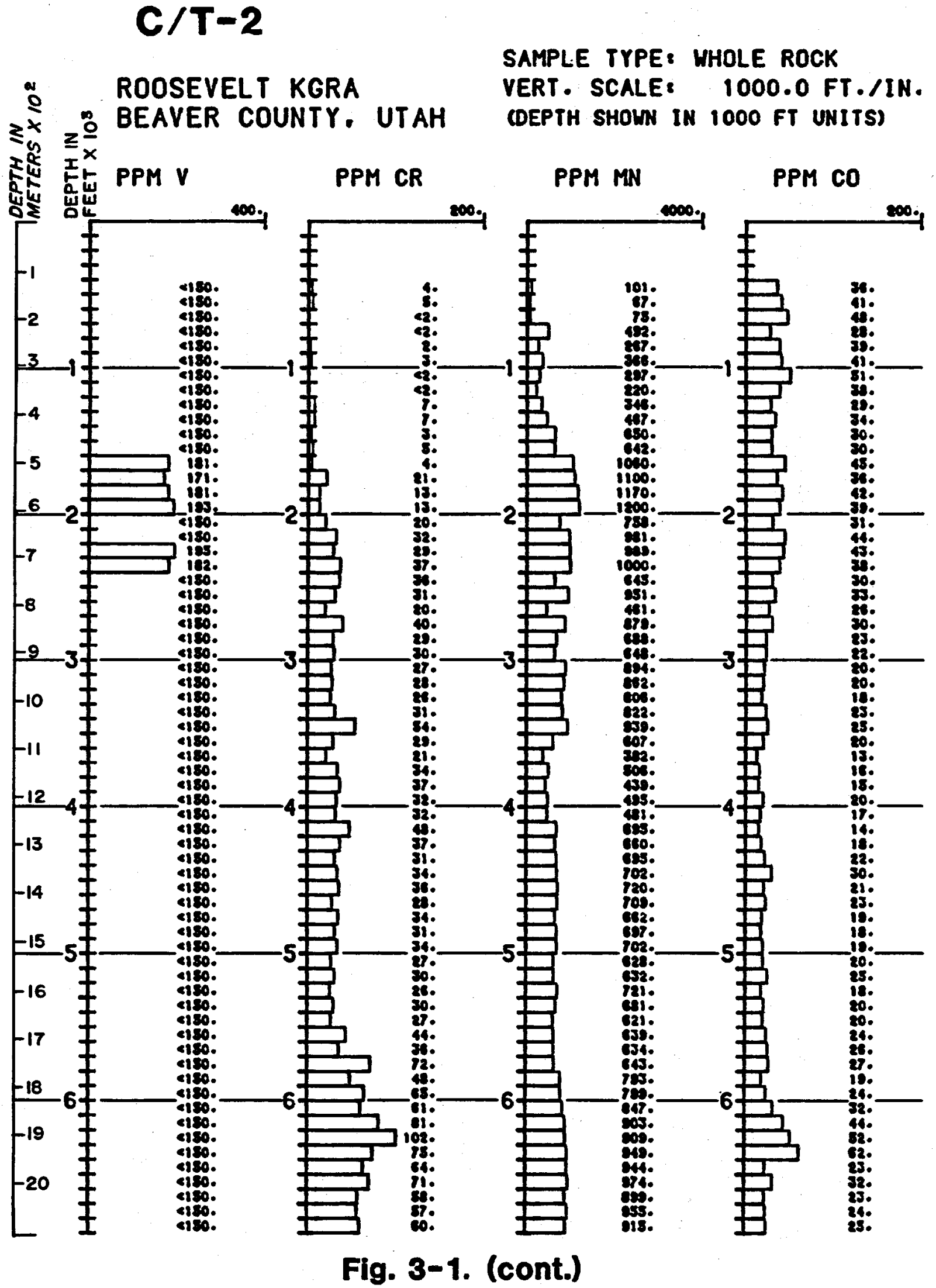


is present in the 204.0-241.0 $\mathrm{m}(670-790 \mathrm{ft})$ section. Detailed analysis of this interval shows $2800 \mathrm{ppb} \mathrm{Hg}$ in the 204.0-213.0 $\mathrm{m}(670-700 \mathrm{ft})$ interval, which is the location of the alluvium-bedrock contact. It is felt that this anomaly was produced by thermal waters which at one time leaked from the 0pal Mound Fault or the western boundary fault of the Opal Mound horst (Fig. 1-3). The entire hanging wall, however, shows a geochemical signature which is compatible with hydrothermal alteration. It will be seen in the next section that this area is characterized by $\delta^{18} 0$ lows produced by equilibrium with thermal waters.

A zone of brecciation and alteration located between $1451.0 \mathrm{~m}$ and 1454.0 m (4760-4770 ft) contains a $\mathrm{Li}$ and As anomaly in the composite geochemistry. This zone does not show an associated $\mathrm{Hg}$ anomaly, but $\mathrm{Hg}$ is probably not stable at the temperatures that exist in this area (J. N. Moore, personal communication). No other zones below the casing show evidence of hot-water entries using reconnaissance geochemical techniques.

\section{Geochemistry of Detailed Study Intervals}

The intervals selected for detailed log interpretation have been analyzed chemically at $3.1 \mathrm{~m}(10 \mathrm{ft})$ intervals. These analyses are presented in Table 3-II. In addition, Table 3-II contains several spot analyses from the upper portion of the drill hole.

\section{E. Rare Earth Element Analyses}

The thermal neutron capture cross sections of several of the rare earth elements are quite large. In particular gadolinium, samarium, and europium have capture cross sections of 46000,5600 , and 1400 Barns respectively (Gearhart-Owen, 1978). To evaluate the influence of these elements on the neutron logs, several spot samples were analyzed by neutron activation techniques. These results are shown in Table 3-III.

The thermal neutron capture cross section for both the monzonite and the granodiorite should fall between 10 and $20 \mathrm{~cm}^{-1}$ (Allen and Mills Jr., 1974; Edmundson and Raymer, 1979). The analysis in Tables 3-II and 3-III indicate that trace elements which have high thermal neutron capture cross sections are not sufficiently concentrated to cause more than $2 \%$ to $3 \%$ change in the rock captive cross section. Larger changes can be expected from mafic mineral 
TABLE 3-II

CHEMICAL ANALYSES OF DRILL CHIP

SAMPLES FROM WELL C/T-2

\section{PHILLIPS 9-1}

\begin{tabular}{|c|c|c|c|c|c|c|c|c|c|c|c|}
\hline DATA & & 200500 & & 2170.00 & & 2280.00 & & $2: 160.00$ & & $21<000$ & ו \\
\hline & & $6 \overline{11} . \overline{1}$ & & $\overline{6} \overline{6} \overline{1.4}$ & & $\overline{6} \overline{8} \overline{8} . \overline{8}$ & & $7 \overline{19.5}$ & & $\overline{49.8}$ & $\bar{M} \bar{E} \overline{T E}$ \\
\hline $\begin{array}{l}5102 \\
\text { TI02 }\end{array}$ & & $\begin{array}{c}63.00 \\
0.01\end{array}$ & & $\begin{array}{r}53.51 \\
\text { 2. } 14\end{array}$ & & $\begin{array}{r}48.07 \\
\text { 2. } 19\end{array}$ & & $\begin{array}{r}56.22 \\
1.12 .\end{array}$ & & $\begin{array}{r}67 \\
1.11\end{array}$ & $\begin{array}{l}\text { Wา } \% \\
\text { wT } \%\end{array}$ \\
\hline AL:?03 & & 17. 20 & & 1677 & & 14. 37 & & 15.45 & & 15. 50 & WT \% \\
\hline FE:D3 & & 312 & & E. 29 & & 11. 01 & & 8. 19 & & 4.93 & WT \% \\
\hline MND & & 0.13 & & 0.16 & & 0.15 & & 0. 12 & & o. 07 & WT $\%$ \\
\hline mev & & 0.1 .5 & & 1.77 & & 3. 17 & & 3. 100 & & 1. 42 & WT $\%$ \\
\hline CAO & & 1.89 & & 5.71 & & 7.:2:2 & & 6. 39 & & 3. 11 & WT \% \\
\hline KaO & & c. 52 & & 3. 15 & & 2. 50 & & $3: 28$ & & 5.36 & WT $\%$ \\
\hline NA2O & & 4. 83 & & 4. $5 ?$ & & 4. $: 79$ & & 1. 47 & & 4. 55 & WT $\%$ \\
\hline $\begin{array}{l}\text { reas } \\
903\end{array}$ & & $\begin{array}{l}0.15 \\
0.03\end{array}$ & & $\begin{array}{l}0.67 \\
0.21\end{array}$ & & $\begin{array}{l}0.10 \\
0.10\end{array}$ & & $\begin{array}{l}0.37 \\
0.18\end{array}$ & & $\begin{array}{l}0.33 \\
0.04\end{array}$ & WT \% \\
\hline Loss & & 1. 12 & & 1.08 & & 1.70 & & 1.90 & & 1.17 & WT \% \\
\hline TOTAL & & 99.53 & & 98.18 & & 97.54 & & 102. 07 & & 100.08 & \\
\hline NR & & 25.00 & & 40.00 & & 35. 00 & & 30.00 & & 30.00 & PPM \\
\hline ZR & & 110.00 & & 180.00 & & 170.00 & & 150.00 & & 210.00 & PPN \\
\hline $\mathbf{Y}$ & & 20.00 & & 30.00 & & 20.00 & & 25. 00 & & 25.00 & PPM \\
\hline SR & & 350.00 & & B15.00 & & 760.00 & & 790.00 & & 600.00 & PPN \\
\hline RB & & 90.00 & & 45.00 & & 65.00 & & 70.00 & & 125.00 & PPM \\
\hline PB & & 25.00 & & 10. 00 & & 10. 00 & & 15.00 & & 00. 00 & PPM \\
\hline BA & & 700.00 & & 700.00 & & 400.00 & & uoo. 00 & & $1: 500.00$ & $P P M$ \\
\hline$v$ & $<$ & 150.00 & $<$ & 150.00 & & 164.00 & $<$ & 150.00 & $<$ & 150.00 & PPM \\
\hline CR & & 2400 & & $2 t .00$ & & 46.00 & & 35.00 & & 36.00 & PPM \\
\hline $\mathrm{CO}$ & & 23. 00 & & 39.00 & & 38.00 & & 33. 00 & & 26.00 & PPN \\
\hline NI & $<$ & 5.00 & & 17.00 & & 27.00 & & 17.00 & & 8. 00 & PPM \\
\hline CU & & 1000 & & 56.00 & & 93.00 & & 60.00 & & 19.00 & PPM \\
\hline MO & $i$ & 50.00 & $<$ & 50. 00 & $<$ & 50.00 & $<$ & 50.00 & $<$ & 50.00 & PPM \\
\hline ZN & & 44. 00 & & 124.00 & & 104.00 & & B2. 00 & & 65.00 & PPM \\
\hline$C D$ & $<$, & 5.00 & $<$ & 5.00 & $<$ & 5. 00 & $<$ & 5.00 & $<$ & 5.00 & PPM \\
\hline$A G$ & $<$ & 2.00 & $<$ & 2. 00 & $<$ & 2.00 & $<$ & 2. 00 & $<$ & 2. 00 & PPM \\
\hline AU & $<$ & 4.00 & $<$ & 4. 00 & $<$ & 4. 100 & $<$ & 4. on & $<$ & 4.00 & PPM \\
\hline AS & $<$ & 1.00 & & 18.00 & & 2. 110 & & 3. 00 & & 4.00 & PPM \\
\hline SD & $<$ & 30.00 & $<$ & 30.00 & $<$ & 30.00 & $<$ & 30.00 & $<$ & 30.00 & PPH \\
\hline B I & $<$ & 100.00 & $<$ & 100.00 & $<$ & 100.00 & $<$ & 100.00 & $<$ & 100.00 & PPM \\
\hline TE & $<$ & 50.00 & $<$ & 50.00 & $<$ & 50.00 & $<$ & 50.00 & $<$ & 5o. 00 & PPH \\
\hline SN & $<$ & 5. 00 & & 7.00 & & 7.00 & & 7.00 & & 5. 00 & PPM \\
\hline LI & & 8. 00 & & 17.00 & & 22. 00 & & 10. 00 & & 14.00 & PPM \\
\hline $\mathrm{BE}$ & & 1. 20 & & 2. 20 & & ‥ 30 & & 2. 30 & & 2. 60 & PPM \\
\hline LA & & 92.00 & & 64.00 & & 40.00 & & 44.00 & & 54.00 & PPM \\
\hline CE & & 157.00 & & 130.00 & & 72. 00 & & 77.00 & & 73. 00 & PPM \\
\hline+16 & & 5.00 & & 25. 00 & & 20.00 & & 15.00 & & 10. 00 & PPB \\
\hline $\begin{array}{l}U \text { (XRF) } \\
U \text { (F) }\end{array}$ & $<$ & $\begin{array}{l}2.00 \\
1.69\end{array}$ & $<$ & $\begin{array}{l}\text { 2. } 00 \\
\text { 2. } 12\end{array}$ & $<$ & $\begin{array}{l}\text { 2. } 00 \\
3.39\end{array}$ & $<$ & $\begin{array}{l}\text { 2. } 00 \\
\text { 2. } 12\end{array}$ & $<$ & $\begin{array}{l}\text { 2. } 00 \\
3.39\end{array}$ & $\begin{array}{l}\text { PPM } \\
\text { PPM }\end{array}$ \\
\hline$U$ (R) & & & & & & & & & & & PPM \\
\hline $\mathrm{TH}$ (R) & & & & & & & & & & & PPM \\
\hline TH (XRF) & & 15.00 & $<$ & 5. 00 & & 10.00 & & 5.00 & & 10. 00 & $\begin{array}{l}\text { PPM } \\
\text { PPM }\end{array}$ \\
\hline
\end{tabular}


TABLE 3-II (cont.)

|HIILLIFI: 7-1

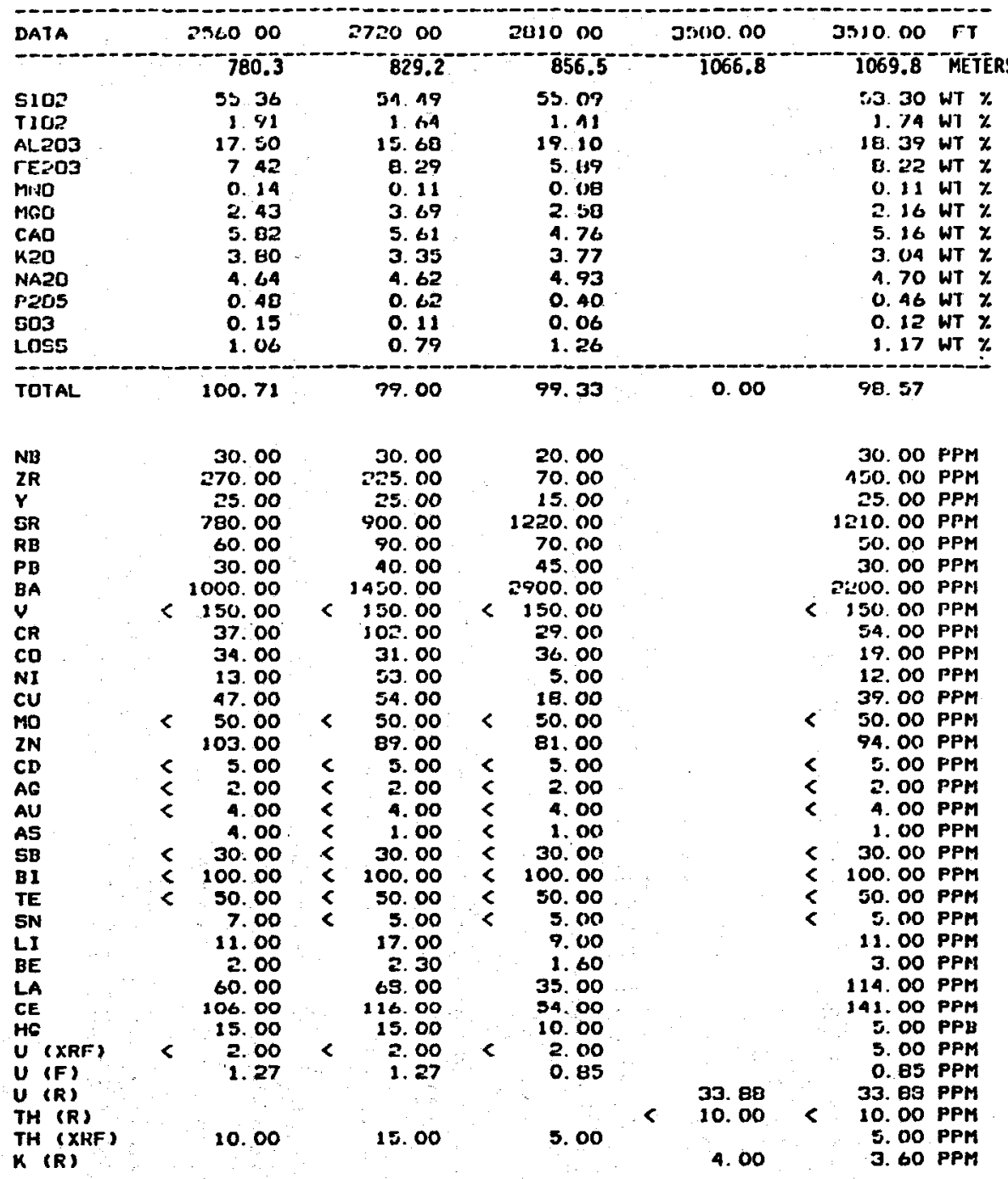


TABLE 3-II (cont.)

PHILLIPS 9-1

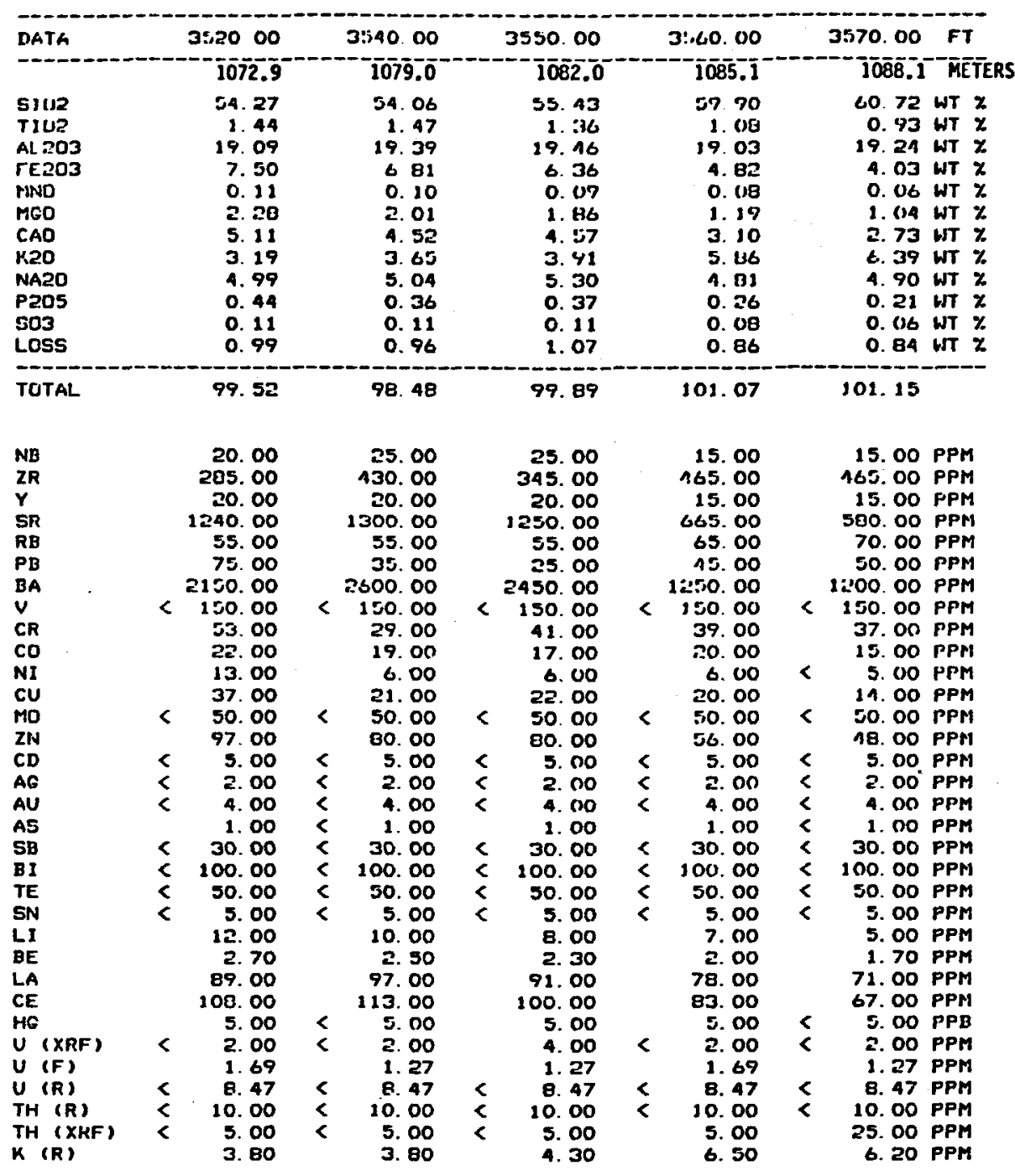


TABLE 3-II (cont.)

PHILLIPG 9-1

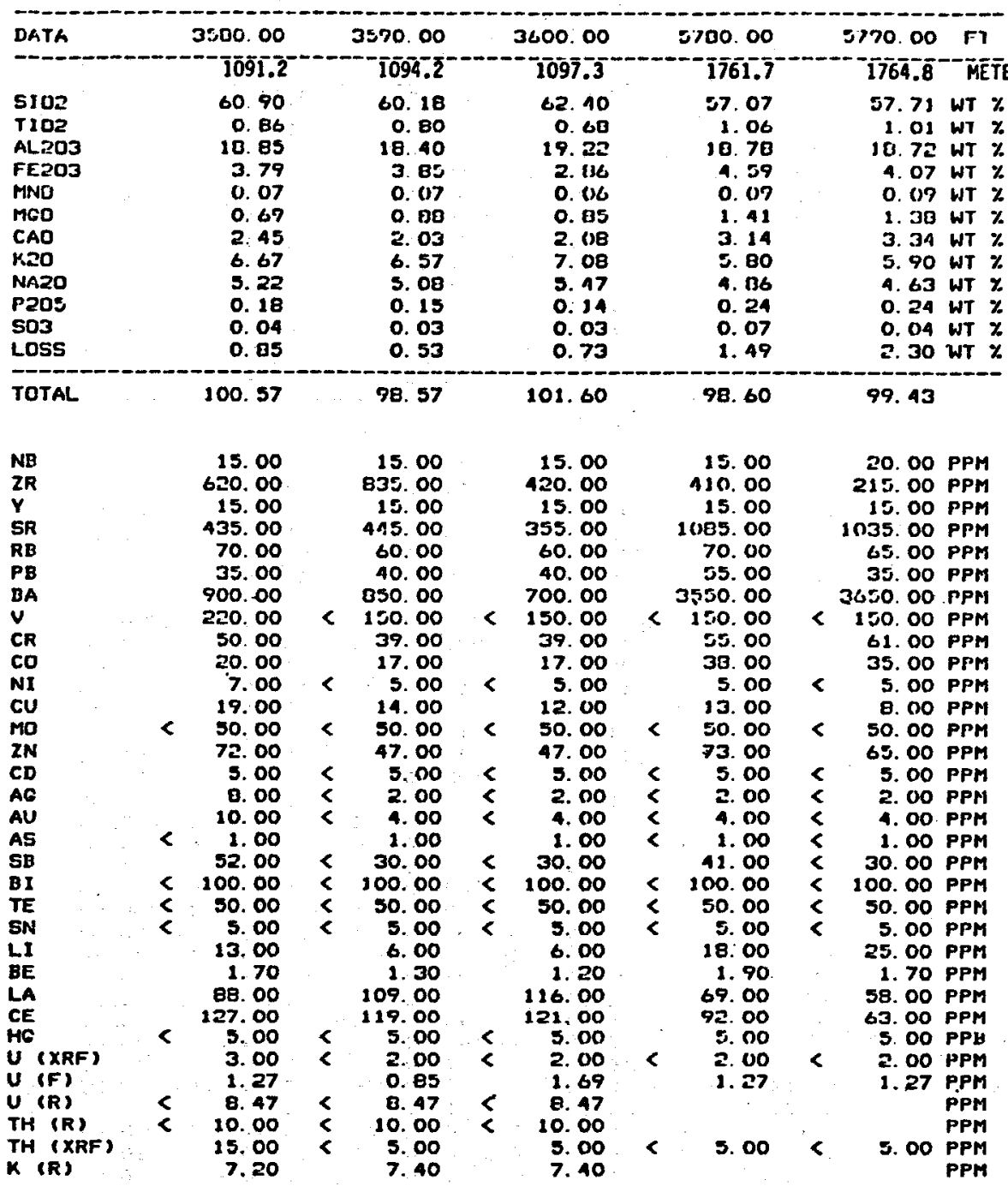




\section{TABLE 3-II (cont.)}

PHILLIPH 9-1

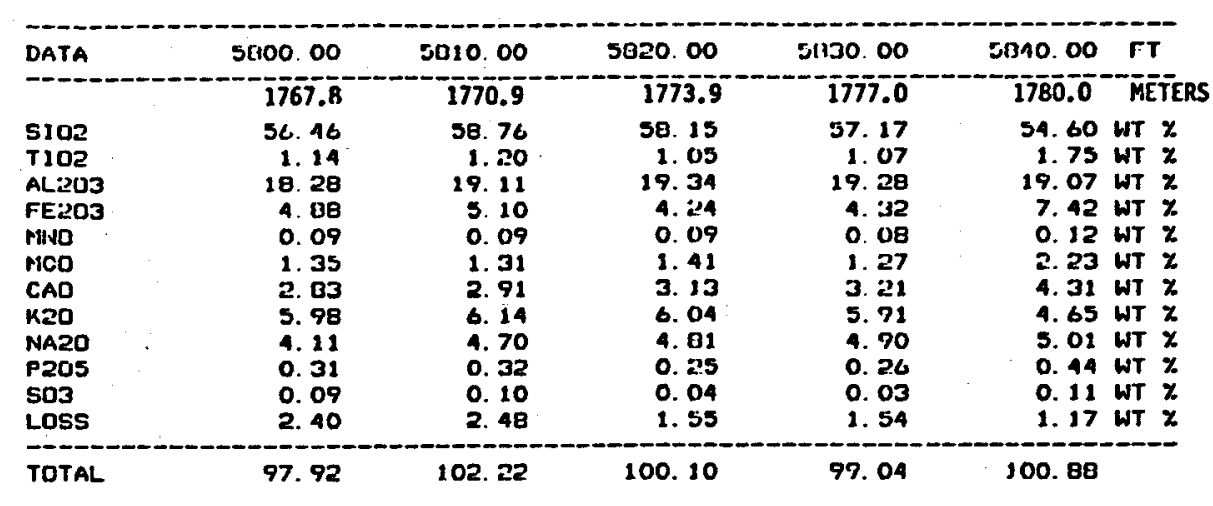

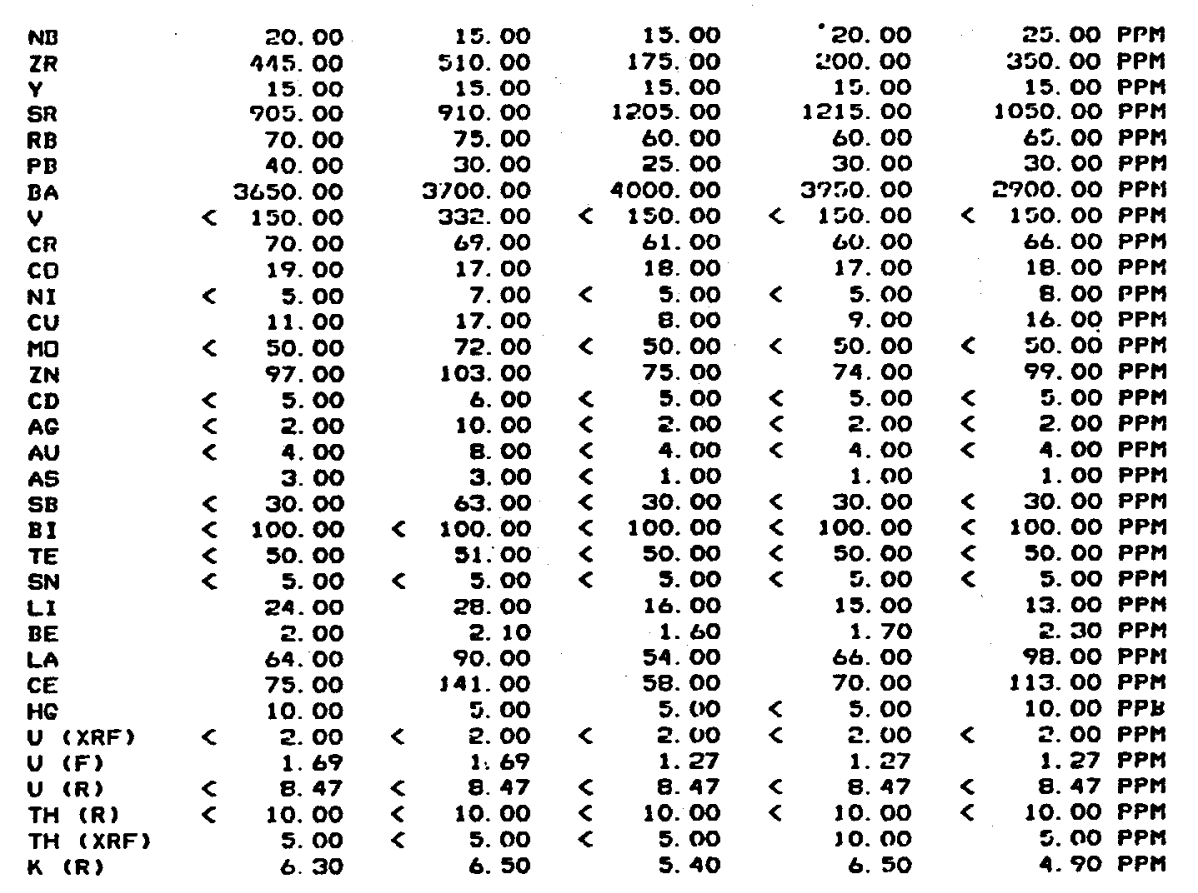


TABLE 3-II (cont.)

[PHILIPS 9-1

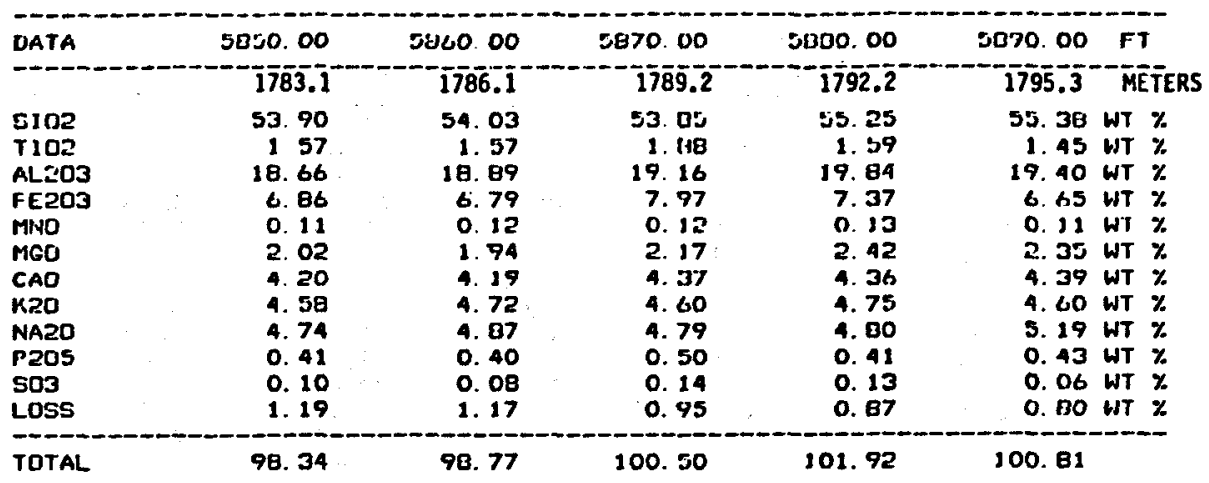

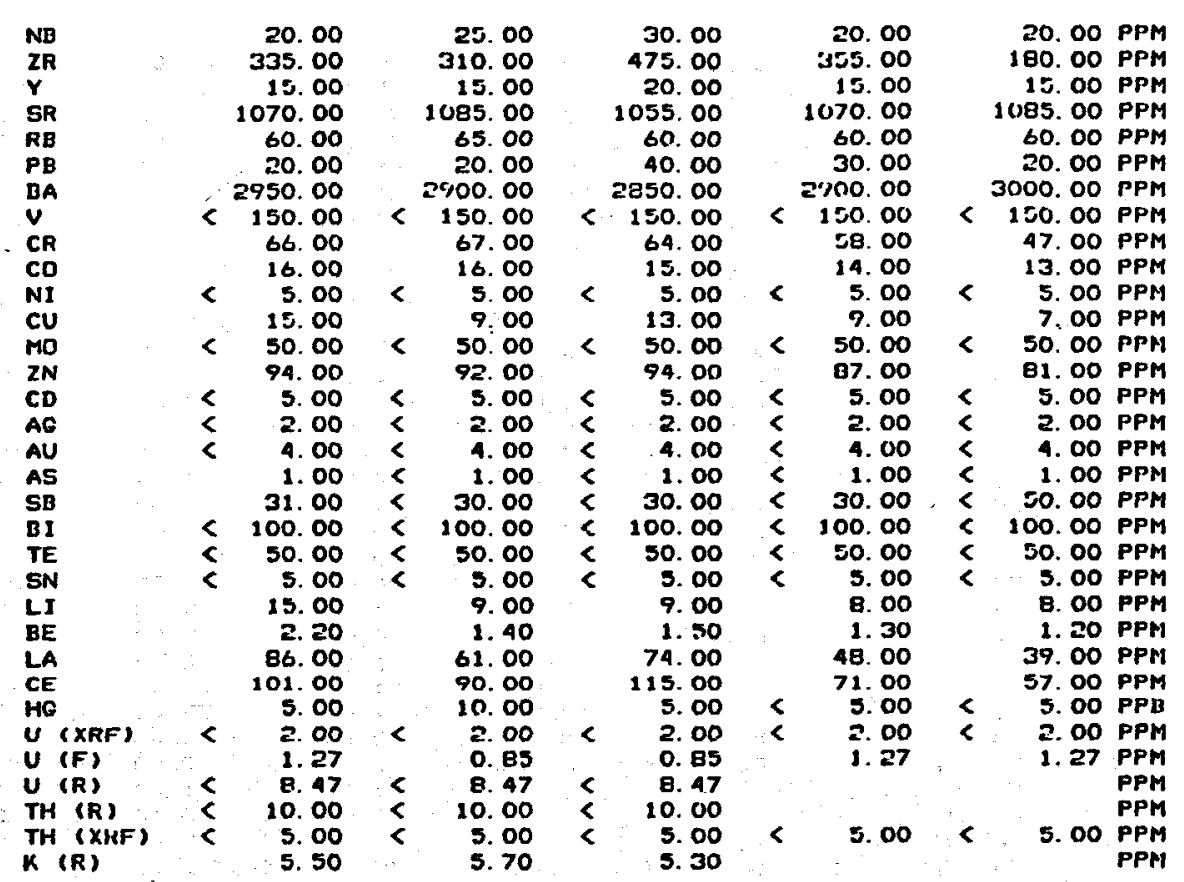


TABLE 3-II (cont.)

PHILLIFS 9-1

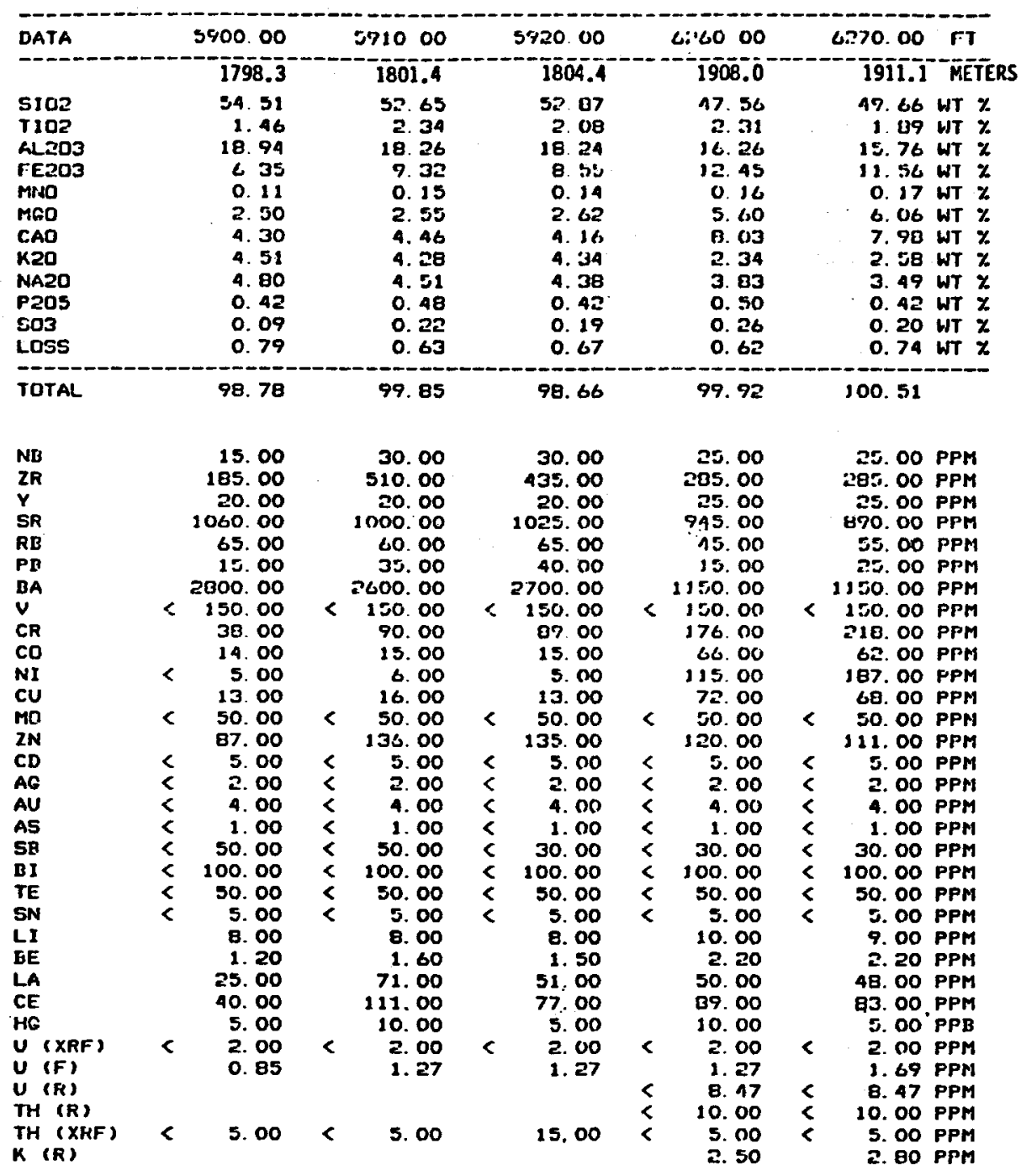


TABLE 3-II (cont.)

PHIILLIF\& 9-1

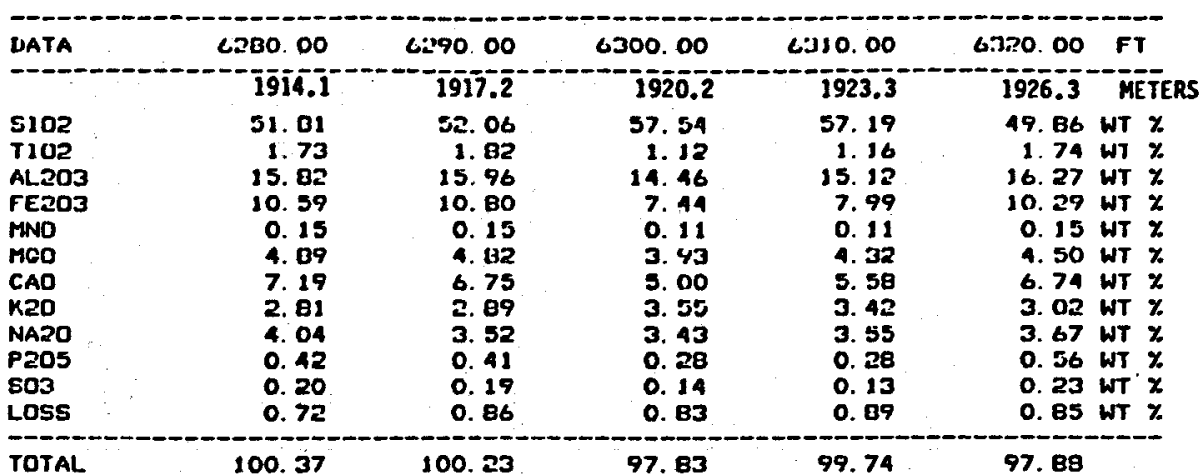

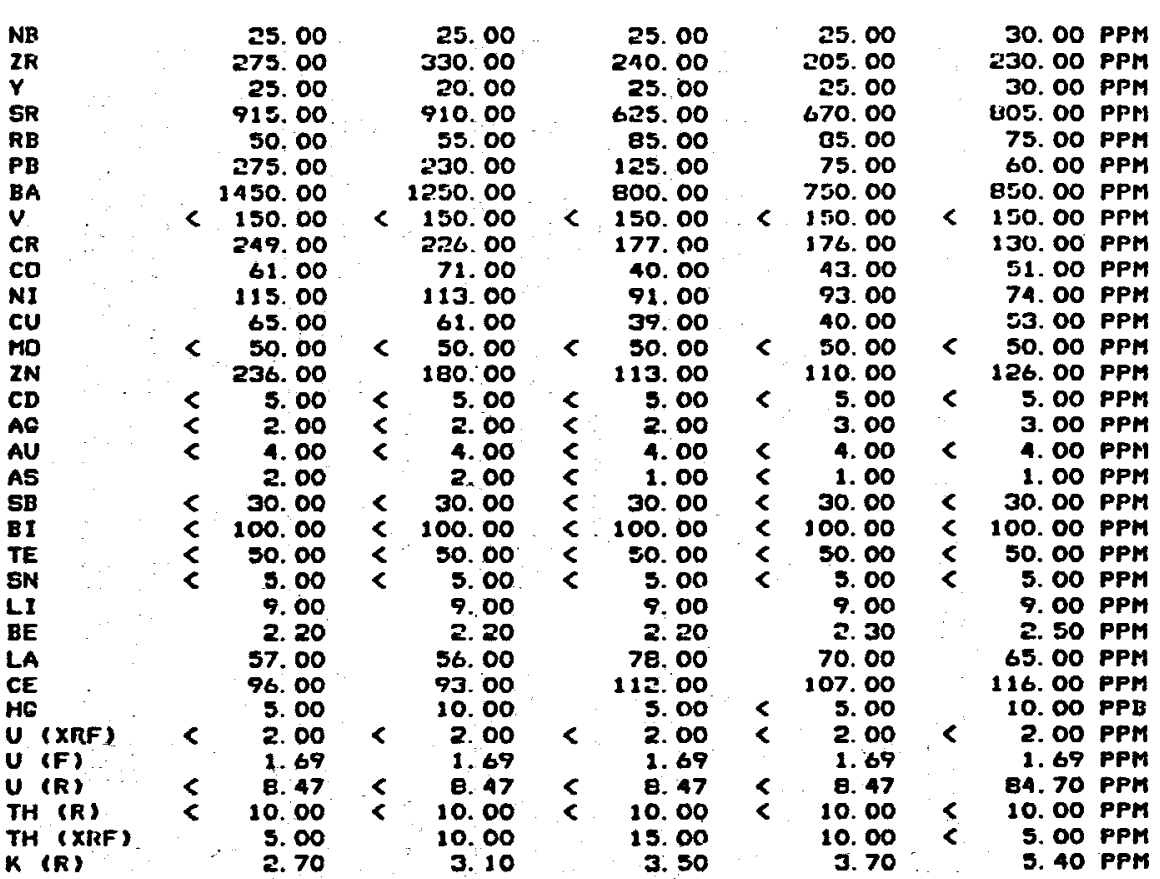


TABLE 3-II (cont.)

[PH] LIPL; 7-1

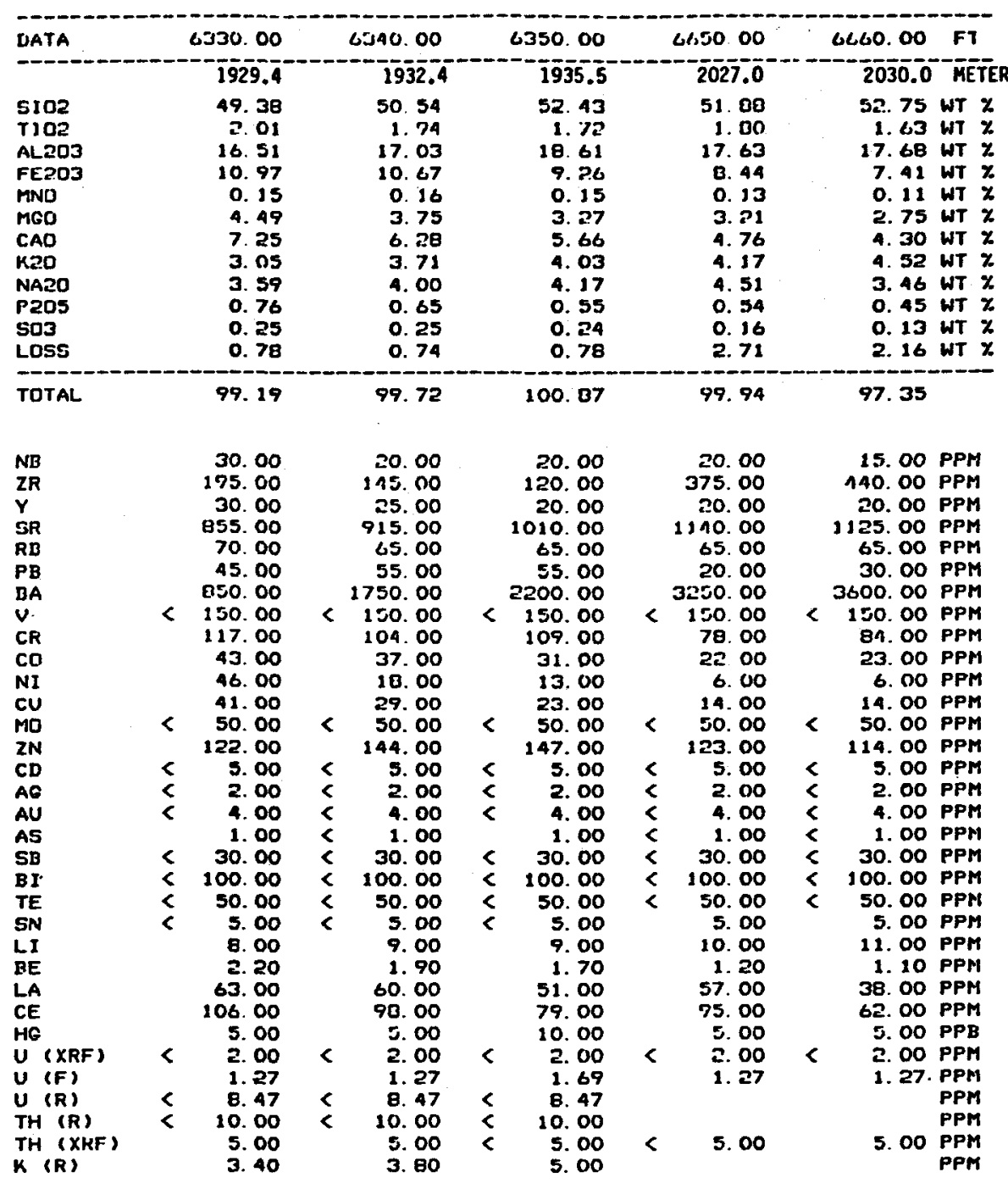


TABLE 3-II (cont.)

IMIIILIFS 9-1

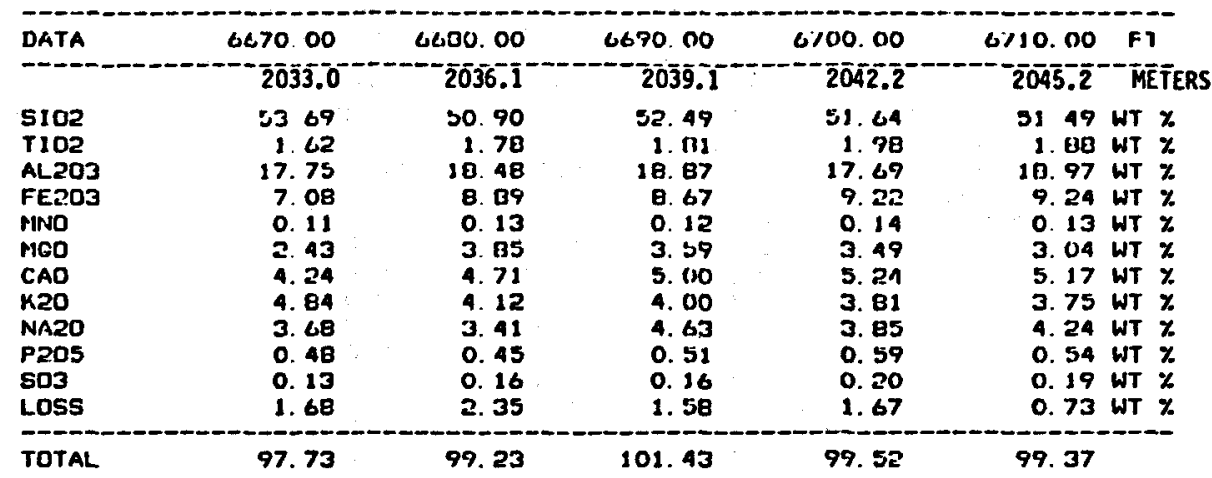

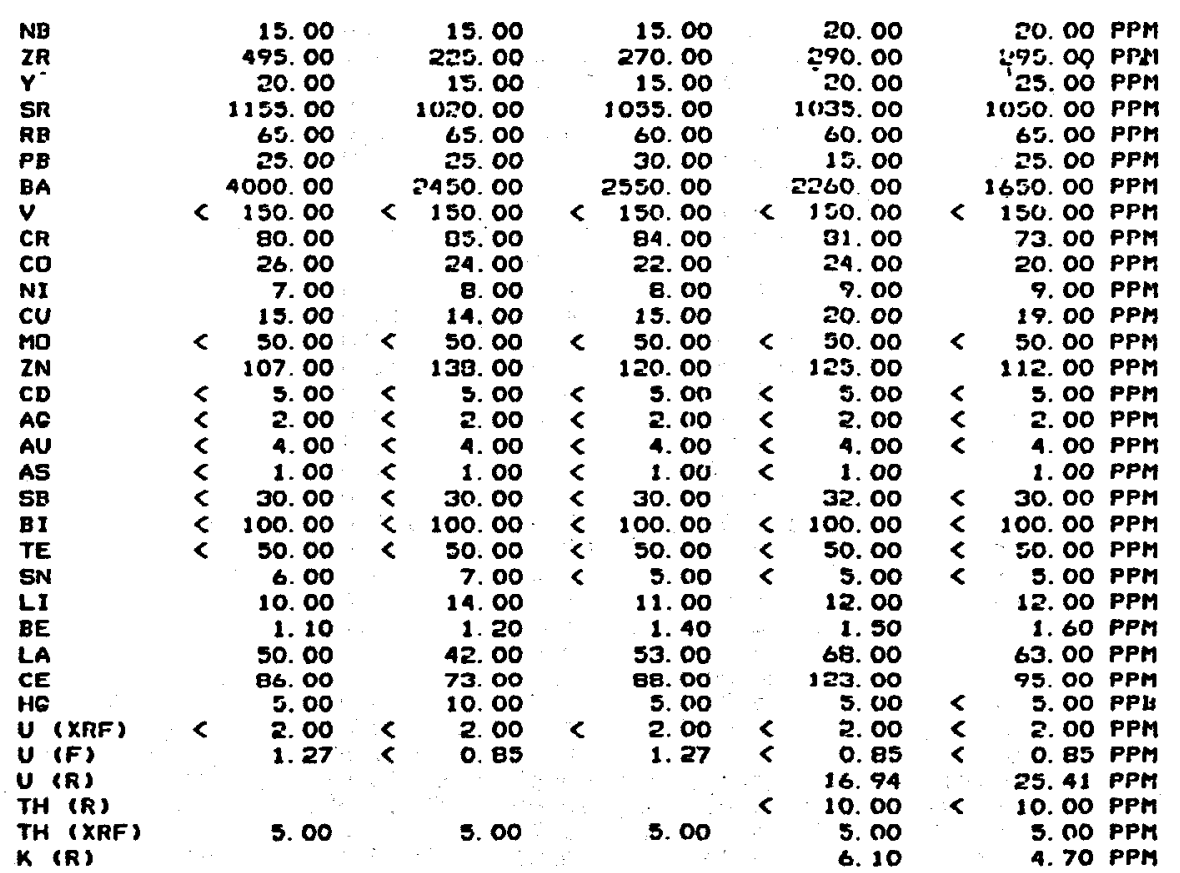




\section{TABLE 3-II (cont.)}

PristLIPS 9-1

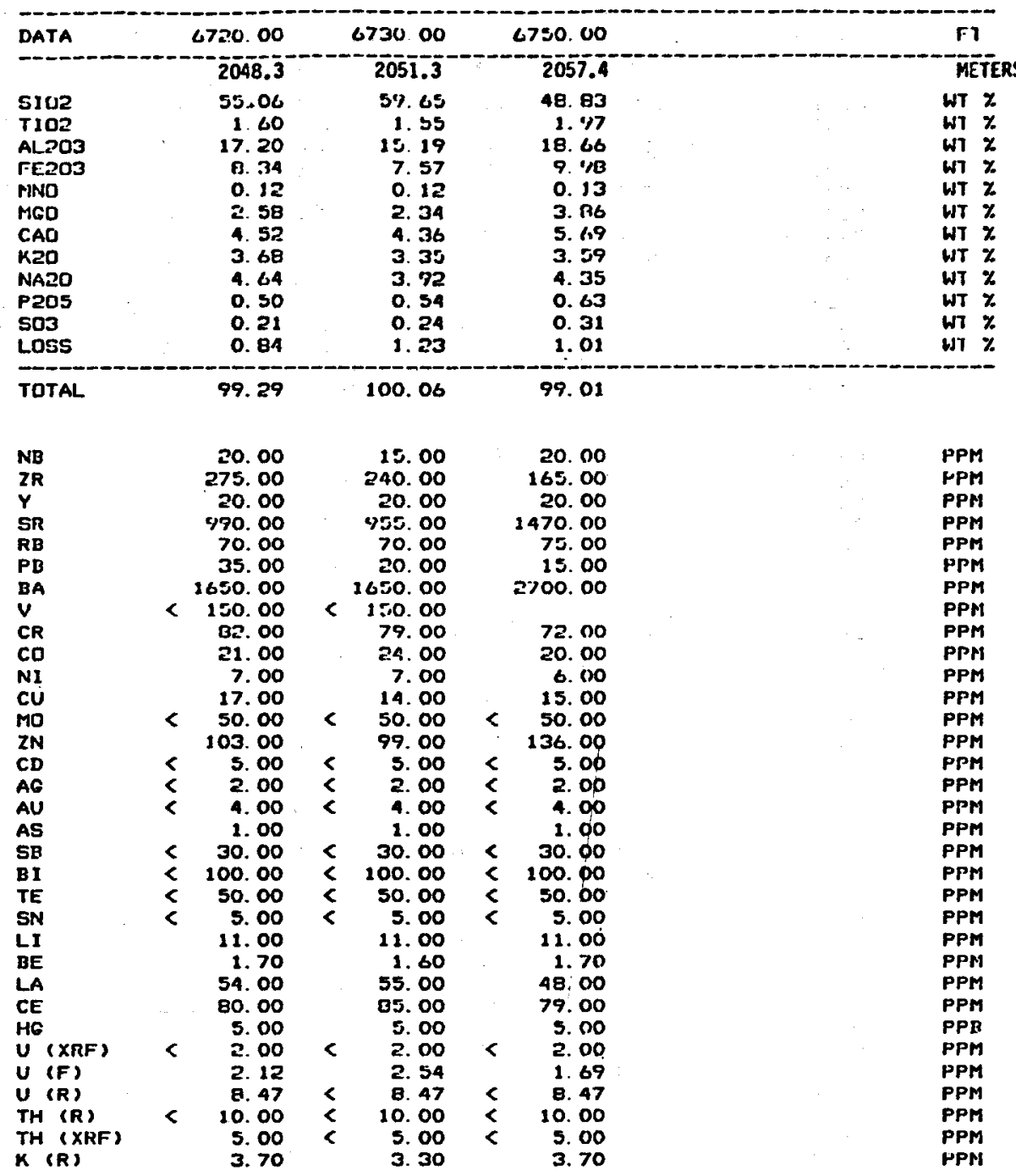


TABLE 3-III

NEUTRON ACTIVATION ANALYSES OF

SELECTED SAMPLES FROM WELL C/T-2

\begin{tabular}{|c|c|c|c|c|c|c|}
\hline \multirow[b]{2}{*}{ ELEMENT } & \multicolumn{6}{|c|}{ SAMPLE INTERVAL } \\
\hline & $\begin{array}{l}1420.3- \\
1423.3 \mathrm{~m} \\
4660- \\
4670 \mathrm{ft}\end{array}$ & $\begin{array}{l}1584.8- \\
1587.9 \mathrm{~m} \\
5200- \\
5210 \mathrm{ft}\end{array}$ & $\begin{array}{l}1642.8- \\
1645.8 \mathrm{~m} \\
5390- \\
5400 \mathrm{ft}\end{array}$ & $\begin{array}{l}1778.9- \\
1783 \mathrm{~m} \\
5840- \\
5850 \mathrm{ft}\end{array}$ & $\begin{array}{l}1874.4- \\
1877.5 \mathrm{~m} \\
1650- \\
6160 \mathrm{ft}\end{array}$ & $\begin{array}{l}1926.2- \\
1929.3 \mathrm{~m} \\
6320- \\
6330 \mathrm{ft}\end{array}$ \\
\hline$\% \mathrm{Fe}$ & $\begin{array}{r}5.79 \\
\pm 0.06 \\
\end{array}$ & $\begin{array}{r}3.94 \\
\pm 0.04 \\
\end{array}$ & $\begin{array}{r}3.62 \\
\pm 0.04 \\
\end{array}$ & $\begin{array}{r}5.12 \\
\pm 0.05\end{array}$ & $\begin{array}{r}6.45 \\
\pm 0.07 \\
\end{array}$ & $\begin{array}{r}7.42 \\
\pm 0.08 \\
\end{array}$ \\
\hline $\mathrm{ppm}$ Sc & $\begin{array}{r}8.00 \\
+0.08\end{array}$ & $\begin{array}{r}7.05 \\
\pm 0.07\end{array}$ & $\begin{array}{r}7.51 \\
\pm 0.08 \\
\end{array}$ & $\begin{array}{r}9.28 \\
\pm 0.10\end{array}$ & $\begin{array}{l}12.37 \\
\pm 0.13\end{array}$ & $\begin{array}{l}16.56 \\
\pm 0.17\end{array}$ \\
\hline $\mathrm{ppm} \mathrm{Cr}$ & $\begin{array}{r}54.5 \\
\pm 0.6 \\
\end{array}$ & $\begin{array}{r}42.4 \\
\pm 0.5 \\
\end{array}$ & $\begin{array}{r}44.7 \\
\pm 0.5 \\
\end{array}$ & $\begin{array}{r}84.9 \\
\pm 0.9\end{array}$ & $\begin{array}{r}130.2 \\
\pm 1.4 \\
\end{array}$ & $\begin{array}{r}117.0 \\
\pm 1.2 \\
\end{array}$ \\
\hline $\mathrm{ppm} \mathrm{Co}$ & $\begin{array}{r}8.68 \\
+0.11 \\
\end{array}$ & $\begin{array}{r}5.41 \\
\pm 0.07 \\
\end{array}$ & $\begin{array}{r}5.90 \\
+0.08 \\
\end{array}$ & $\begin{array}{r}9.62 \\
\pm 0.11 \\
\end{array}$ & $\begin{array}{r}16.63 \\
\pm 0.18 \\
\end{array}$ & $\begin{array}{r}38.9 \\
+\quad 0.4 \\
\end{array}$ \\
\hline $\mathrm{ppm} \mathrm{Zr^{* }}$ & $\begin{array}{r}2540 \\
+50 \\
\end{array}$ & $\begin{array}{r}1330 \\
\pm 30 \\
\end{array}$ & $\begin{array}{r}1320 \\
\pm 40 \\
\end{array}$ & $\begin{array}{r}1080 \\
\pm 30 \\
\end{array}$ & $\begin{array}{r}490 \\
\pm 40 \\
\end{array}$ & $\begin{array}{r}440 \\
\pm 40 \\
\end{array}$ \\
\hline $\mathrm{ppm} \mathrm{Hf}$ & $\begin{array}{l}26.1 \\
\pm 0.3 \\
\end{array}$ & $\begin{array}{r}14.62 \\
\pm 0.15\end{array}$ & $\begin{array}{r}12.42 \\
\pm 0.13 \\
\end{array}$ & $\begin{array}{r}9.18 \\
\pm 0.10 \\
\end{array}$ & $\begin{array}{r}4.69 \\
\pm 0.06 \\
\end{array}$ & $\begin{array}{r}4.72 \\
\pm 0.06\end{array}$ \\
\hline $\mathrm{ppm} \mathrm{Ta}$ & $\begin{array}{r}1.27 \\
+0.03\end{array}$ & $\begin{array}{r}1.02 \\
\pm 0.02 \\
\end{array}$ & $\begin{array}{r}1.10 \\
\pm 0.02 \\
\end{array}$ & $\begin{array}{r}0.89 \\
+0.02\end{array}$ & $\begin{array}{r}0.78 \\
+0.02 \\
\end{array}$ & $\begin{array}{r}1.30 \\
\pm 0.03 \\
\end{array}$ \\
\hline ppm Th & $\begin{array}{r}4.74 \\
+0.05 \\
\end{array}$ & $\begin{array}{r}2.43 \\
+0.04 \\
\end{array}$ & $\begin{array}{r}5.63 \\
\pm 0.06 \\
\end{array}$ & $\begin{array}{r}2.76 \\
\pm 0.03 \\
\end{array}$ & $\begin{array}{r}2.63 \\
\pm 0.03 \\
\end{array}$ & $\begin{array}{r}4.32 \\
\pm 0.05 \\
\end{array}$ \\
\hline $\mathrm{ppmU}$ & n.d. & n.d. & $\begin{array}{r}1.15 \\
\pm 0.14 \\
\end{array}$ & n.d. & n.d. & n.d. \\
\hline$\% \mathrm{Na}$ & $\begin{array}{r}3.76 \\
+0.06 \\
\end{array}$ & $\begin{array}{r}3.87 \\
\pm 0.06 \\
\end{array}$ & $\begin{array}{r}3.62 \\
\pm 0.06 \\
\end{array}$ & $\begin{array}{r}3.70 \\
+0.06 \\
\end{array}$ & $\begin{array}{r}3.67 \\
+0.06 \\
\end{array}$ & $\begin{array}{r}3.11 \\
\pm 0.05 \\
\end{array}$ \\
\hline $\mathrm{ppm} \mathrm{Ba}$ & $\begin{array}{r}2950 \\
\pm 30 \\
\end{array}$ & $\begin{array}{r}2950 \\
\pm 30\end{array}$ & $\begin{array}{r}2480 \\
\pm 30 \\
\end{array}$ & $\begin{array}{r}2740 \\
\pm 30 \\
\end{array}$ & $\begin{array}{r}2900 \\
+30 \\
\end{array}$ & $\begin{array}{r}1830 \\
\pm 20\end{array}$ \\
\hline $\mathrm{ppm} \mathrm{Rb}$ & $\begin{array}{r}62.7 \\
+\quad+.4\end{array}$ & $\begin{array}{r}64.7 \\
+1.3\end{array}$ & $\begin{array}{r}78.3 \\
\pm 1.4\end{array}$ & $\begin{array}{r}49.5 \\
+1.3\end{array}$ & $\begin{array}{r}59.2 \\
+1.5\end{array}$ & $\begin{array}{r}71.1 \\
+7.5\end{array}$ \\
\hline ppm Cs & $\begin{array}{r}0.48 \\
+0.05 \\
\end{array}$ & $\begin{array}{r}0.44 \\
\pm 0.03 \\
\end{array}$ & $\begin{array}{r}0.86 \\
\pm 0.04 \\
\end{array}$ & $\begin{array}{r}0.68 \\
+0.04 \\
\end{array}$ & $\begin{array}{r}0.72 \\
\pm 0.04\end{array}$ & $\begin{array}{r}0.81 \\
+0.05 \\
\end{array}$ \\
\hline ppm La & $\begin{array}{r}86 \\
\pm 5 \\
\end{array}$ & $\begin{array}{r}68 \\
\pm 3 \\
\end{array}$ & $\begin{array}{r}67 \\
\pm 2 \\
\end{array}$ & $\begin{array}{r}73 \\
\pm 2 \\
\end{array}$ & $\begin{array}{r}72 \\
+2 \\
\end{array}$ & $\begin{array}{r}64 \\
\pm 2 \\
\end{array}$ \\
\hline $\mathrm{ppm} \mathrm{Ce}$ & $\begin{array}{r}120.6 \\
\pm 1.7 \\
\end{array}$ & $\begin{array}{r}125.3 \\
+1.3 \\
\end{array}$ & $\begin{array}{r}109.8 \\
+1.1 \\
\end{array}$ & $\begin{array}{r}142.6 \\
+1.4 \\
\end{array}$ & $\begin{array}{r}134.2 \\
+1.4 \\
\end{array}$ & $\begin{array}{r}137.5 \\
+1.4 \\
\end{array}$ \\
\hline $\mathrm{ppm} \mathrm{Nd}$ & $\begin{array}{r}98 \\
\pm 2 \\
\end{array}$ & $\begin{array}{r}78 \\
\pm 2 \\
\end{array}$ & $\begin{array}{r}65.4 \\
\pm 1.9 \\
\end{array}$ & $\begin{array}{r}80 \\
+2 \\
\end{array}$ & $\begin{array}{r}82 \\
\pm 3 \\
\end{array}$ & $\begin{array}{r}92 \\
+3\end{array}$ \\
\hline $\mathrm{ppm} \mathrm{Sm}$ & $\begin{array}{l}13.55 \\
\pm 0.15\end{array}$ & $\begin{array}{l}10.18 \\
\pm 0.12\end{array}$ & $\begin{array}{r}8.48 \\
\pm 0.10\end{array}$ & $\begin{array}{r}10.51 \\
\pm 0.12\end{array}$ & $\begin{array}{l}11.04 \\
\pm 0.13\end{array}$ & $\begin{array}{l}13.10 \\
\pm 0.15\end{array}$ \\
\hline ppm Eu & $\begin{array}{r}5.80 \\
\pm 0.08\end{array}$ & $\begin{array}{r}4.73 \\
+0.06 \\
\end{array}$ & $\begin{array}{r}4.19 \\
+0.06 \\
\end{array}$ & $\begin{array}{r}4.11 \\
+0.05 \\
\end{array}$ & $\begin{array}{r}4.31 \\
+0.06 \\
\end{array}$ & $\begin{array}{r}3.36 \\
+0.05 \\
\end{array}$ \\
\hline ppm GdF & $\begin{array}{r}7.95 \\
+0.18 \\
\end{array}$ & $\begin{array}{r}5.1 \\
\pm 0.2 \\
\end{array}$ & $\begin{array}{r}4.79 \\
\pm 0.13 \\
\end{array}$ & $\begin{array}{r}6.16 \\
+0.16 \\
\end{array}$ & $\begin{array}{r}5.7 \\
+0.4 \\
\end{array}$ & $\begin{array}{r}8.1 \\
+0.4 \\
\end{array}$ \\
\hline $\mathrm{ppm} \mathrm{Tb}$ & $\begin{array}{r}1.113 \\
\pm 0.019\end{array}$ & $\begin{array}{r}0.733 \\
\pm 0.013\end{array}$ & $\begin{array}{r}0.726 \\
\pm 0.016\end{array}$ & $\begin{array}{r}0.850 \\
\pm 0.014\end{array}$ & $\begin{array}{r}0.723 \\
\pm 0.015\end{array}$ & $\begin{array}{r}1.172 \\
\pm 0.019\end{array}$ \\
\hline
\end{tabular}


TABLE 3-III (cont.)

\begin{tabular}{|c|c|c|c|c|c|c|}
\hline \multirow[b]{2}{*}{ ELEMENT } & \multicolumn{6}{|c|}{ SAMPLE INTERVAL } \\
\hline & $\begin{array}{l}1420.3- \\
1423.3 \mathrm{~m} \\
4660- \\
4670 \mathrm{ft}\end{array}$ & $\begin{array}{l}1584.8- \\
1587.9 \mathrm{~m} \\
5200- \\
5210 \mathrm{ft}\end{array}$ & $\begin{array}{l}1642.8- \\
1645.8 \mathrm{~m} \\
5390- \\
5400 \mathrm{ft}\end{array}$ & $\begin{array}{l}1778.9- \\
1783 \mathrm{~m} \\
5840- \\
5850 \mathrm{ft}\end{array}$ & $\begin{array}{l}1874.4- \\
1877.5 \mathrm{~m} \\
6150- \\
6160 \mathrm{ft}\end{array}$ & $\begin{array}{l}1926.2- \\
1929.3 \mathrm{~m} \\
6320- \\
6330 \mathrm{ft}\end{array}$ \\
\hline $\mathrm{ppm} Y \mathrm{~b}$ & $\begin{array}{r}2.93 \\
+0.06\end{array}$ & $\begin{array}{r}2.37 \\
+0.05\end{array}$ & $\begin{array}{r}1.73 \\
+0.04\end{array}$ & $\begin{array}{r}1.67 \\
+0.04\end{array}$ & $\begin{array}{r}1.56 \\
\pm 0.06\end{array}$ & $\begin{array}{r}3.03 \\
+0.06\end{array}$ \\
\hline $\mathrm{ppm} L \mathrm{Lu}$ & $\begin{array}{r}0.388 \\
+0.005\end{array}$ & $\begin{array}{r}0.277 \\
+0.004\end{array}$ & $\begin{array}{r}0.278 \\
\pm 0.004\end{array}$ & $\begin{array}{r}0.240 \\
\pm 0.004\end{array}$ & $\begin{array}{r}0.217 \\
+0.004\end{array}$ & $\begin{array}{r}0.362 \\
\pm 0.005\end{array}$ \\
\hline
\end{tabular}

* Zr values are unnormalized and may incorporate systematic errors FGd values estimated by interpolation, not determined by analysis Analyst: Gordon Goles, University of Oregon 
(biotite, hornblende, chlorite, etc.) variations. This effect will be examined in Section VI.

F. Fluid Chemistry

Table 3-IV gives two analyses of water from Well C/T-2. The first analysis is from Parry et al. (1976). The second analysis is of water collected in 1979 (Newman, 1979). Because water in the well is stagnant, some change in chemistry may be expected. In addition, chemical gradients may exist or develop in the fluid in the borehole.

\section{OXYGEN AND CARBON ISOTOPE ANALYSES}

\section{A. Introduction}

Stable isotopes of carbon and oxygen have been used effectively to estimate the temperatures of deposition of hydrothermal minerals (Ohmoto and Rye, 1979; Taylor, 1979). This estimate is accomplished by measurement of the isotopic compositions of minerals and either a measurement or an estimation of the isotopic compositions of fluids with which the minerals are in equilibrium. Carbon and oxygen isotopic analyses of alteration phases such as calcite have been useful in determining fluid entries in some geothermal systems (Kendall, 1976, Elders, et a1., 1978).

To document and quantify the hydrothermal processes effecting Well $\mathrm{C} / \mathrm{T}-2$, twenty-six samples were selected for stable isotope analysis of carbonate minerals. Analyses of carbon and oxygen isotopes in calcite provide a base from which temperatures may be estimated and trends of isotopic enrichment or depletion can be correlated with entries identified by logging or geochemical signatures such as mercury or arsenic anomalies.

Calcite is a common alteration phase in the Roosevelt Hot Springs geothermal system and is particularly abundant in highly altered zones that are related to fault structures (see section on lithologic logging). Carbonate veins cross-cutting older carbonate veins have been observed in thin section, along with carbonate replacements in plagioclase. In addition, altered zones frequently contain veinlets of fine grained quartz, which are also related to the hydrothermal process. However, efforts to sample these veins for isotopic analysis were unsuccessful because of their fine-grain 
TABLE 3-IV

WATER ANALYSES FROM WELL C/T-2

$\begin{array}{lrr} & 1(\mathrm{ppm}) & \frac{2(\mathrm{ppm})}{2000} \\ \mathrm{Na} & 2210 & 41 \\ \mathrm{Ca} & 83 & 374 \\ \mathrm{~K} & 425 & 362 \\ \mathrm{SiO}_{2} & 364 & 0.74 \\ \mathrm{Mg} & - & 2140 \\ \mathrm{Cl} & 3800 & 67 \\ \mathrm{SO}= & 122 & 5.1 \\ \mathrm{Fe} & & 0.41 \\ \mathrm{Mn} & & 4.7 \\ \mathrm{Sr} & & .41 \\ \mathrm{Ba} & & 28 \\ \mathrm{~B} & & 19 \\ \mathrm{Li} & & 24 \\ \mathrm{NH} 4 & & 6520 \\ \mathrm{TDS} & & 5.9 \\ \mathrm{pH} & & \end{array}$

NOTES:

1 - Analysis from Parry et a1., 1976.

2 - Analysis from Newman, 1979. 
size.

B. Sample Preparation and Analyses

The samples analyzed were from drill cuttings collected at 3.1 and $4.6 \mathrm{~m}$ (10 and $15 \mathrm{ft}$ ) intervals. Thus, the analyses presented are average values for these intervals and no distinction is made for separate carbonates of different ages. Cuttings from selected 3.1 or $4.6 \mathrm{~m}$ (10 or $15 \mathrm{ft}$ ) intervals were crushed to less than 200 mesh. For several intervals, the samples of 80 to 150 mesh were analyzed to test the influence of grain size on the isotopic values. Approximately $500 \mathrm{mg}$ of sample was reacted with $100 \%$ distilled phosphoric acid for 12 to $15 \mathrm{~h}$ at $25^{\circ} \mathrm{C}$ (McCrea, 1950). The liberated $\mathrm{CO}_{2}$ gas was then extracted and purified for carbon and oxygen isotopic analysis. The gas was analyzed on a Micromass Model 602D, twin-collecting, $90^{\circ}$ mass spectrometer.

The isotope data are reported as $\delta^{18} 0$ or $\delta^{13} \mathrm{C}$ where:

$$
\delta=\left(\frac{R_{\text {sample }}}{R_{\text {standard }}}-1\right) 1000
$$

and $R_{\text {sample }}$ is the ${ }^{18} 0 /{ }^{16} 0$ or ${ }^{13} \mathrm{C} /{ }^{12} / \mathrm{C}$ ratio in the sample and $\mathrm{R}_{\text {standard }}$ is the corresponding ratio for the standard. The standards used are Standard Mean Ocean Water (SMOW) for oxygen (Craig, 1961) and the Chicago PDB Standard for carbon (Craig, 1957). A $\delta$-value $=+5$ would mean that the sample is $5 / m i l$ (5 parts per thousand) or $0.5 \%$ richer in ${ }^{18} 0$ than SMOW or ${ }^{13} \mathrm{C}$ than PDB. Negative numbers signify relative depletion in the heavy isotopes.

\section{Results}

The oxygen and carbon isotopic analyses for Well C/T-2 are listed in Table 4-I and plotted as a function of depth in Figs. 4-1 and 4-2. In addition, the $\delta^{18} 0$ and $\delta^{13} \mathrm{C}$ values are plotted against each other in $\mathrm{Fig}$. 4-3. The $\delta^{18} 0$ values range from -0.4 to $+9.7 \%$ and exhibit no systematic variation with depth except for a gross trend of increasing $\delta^{18} 0$ with depth. Conversely, the $\delta^{13} \mathrm{C}$ values show less scatter and a pronounced decrease with increasing depth, with values ranging from -0.7 to $8.2^{0} / 00$. The $\delta^{18} 0$ values of the coarse-grained samples are isotopically lighter than their fine-grained 
TABLE 4-I

OXYGEN AND CARBON ISOTOPE

DATA FROM WELL C/T-2

\begin{tabular}{c} 
DEPTH \\
INTERVAL \\
\hline$(\mathrm{m})$ \\
$236.2-240.8$ \\
$275.8-280.4$ \\
$359.7-364.2$ \\
$368.8-378.0$ \\
$446.5-451.1$ \\
$492.3-496.8$ \\
$515.1-519.7$ \\
$592.8-597.4$ \\
$611.1-615.7$ \\
$615.7-620.3$ \\
$734.6-737.6$ \\
$835.2-838.2$ \\
$862.6-865.6$ \\
$1002.8-1005.8$ \\
$1063.8-1066.8$ \\
$1185.7-1188.7$ \\
$1292.4-1295.4$ \\
$1450.8-1362.5$ \\
$1505.7-1508.8$ \\
$1734.3-1737.4$ \\
$1764.8-1767.8$ \\
$1795.3-1798.3$ \\
$1895.9-1898.9$ \\
$1914.1-1917.2$ \\
$1941.6-1944.6$ \\
$2026.9-2030.0$
\end{tabular}

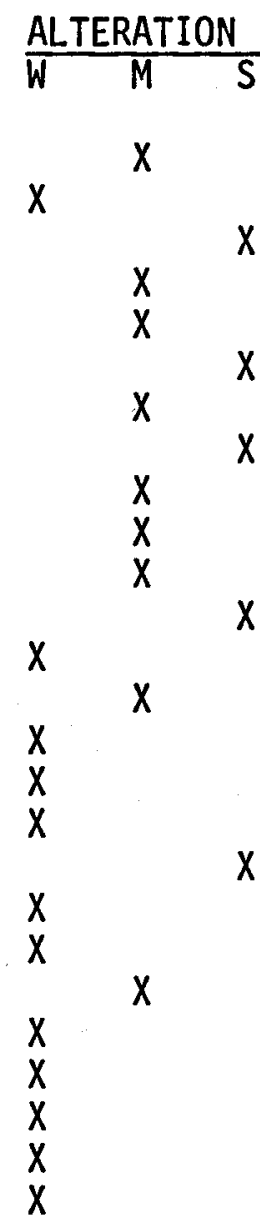

\begin{tabular}{|c|c|}
\hline \multicolumn{2}{|c|}{ POWDERED } \\
\hline$\delta^{18} 00 / 00$ & $\delta^{3}{ }^{3} \mathrm{CO} / \mathrm{O}$ \\
\hline $\begin{array}{l}+6.7 \\
+9.3 \\
+0.4 \\
+0.4 \\
+0.8 \\
+1.8 \\
+2.2 \\
+0.7 \\
+2.6 \\
+2.5 \\
+4.7 \\
-0.3 \\
+5.2 \\
+1.3 \\
+7.0 \\
+3.5 \\
+7.3 \\
-0.4 \\
+7.2 \\
+6.6 \\
-0.2 \\
+5.3 \\
+7.6 \\
+5.7 \\
+9.7 \\
+4.8\end{array}$ & $\begin{array}{l}-3.6 \\
-2.4 \\
-3.1 \\
-1.8 \\
-0.7 \\
-3.5 \\
-3.8 \\
-3.3 \\
-4.7 \\
-4.1 \\
-5.0 \\
-4.5 \\
-5.5 \\
-4.1 \\
-3.4 \\
-3.5 \\
-7.3 \\
-5.0 \\
-3.8 \\
-5.4 \\
-5.1 \\
-4.5 \\
-6.5 \\
-5.4 \\
-8.2 \\
-4.0\end{array}$ \\
\hline
\end{tabular}

$\delta^{18} 00 \% \frac{\text { COARSE }}{\delta^{13} \mathrm{C} / 00}$

(ft)

$775-790$

905-920

$1180-1195$

$1210-1240$

1465-1480

$1615-1630$

1690-1705

$1945-1960$

2005-2020

2020-2035

2410-2420

$2740-2750$

2830-2840

$3290-3300$

3490-3500

$3890-3900$

$4240-4250$

$4760-4770$

$4940-4950$

$5690-5700$

5790-5800

5890-5900

6220-6230

$6280-6290$

$6370-6380$

$6650-6660$

Analyst: DAVID ROHRS

Alteration: $W$ (weak); M(moderate); S(strong)

Powered Samples $=200$

Coarse Samples $=+80$ to +150 mesh

$\begin{array}{ll}-0.3 & -0.9 \\ +0.7 & -2.6 \\ -0.7 & -3.2 \\ -1.1 & -4.3 \\ & \\ -1.0 & -4.8\end{array}$




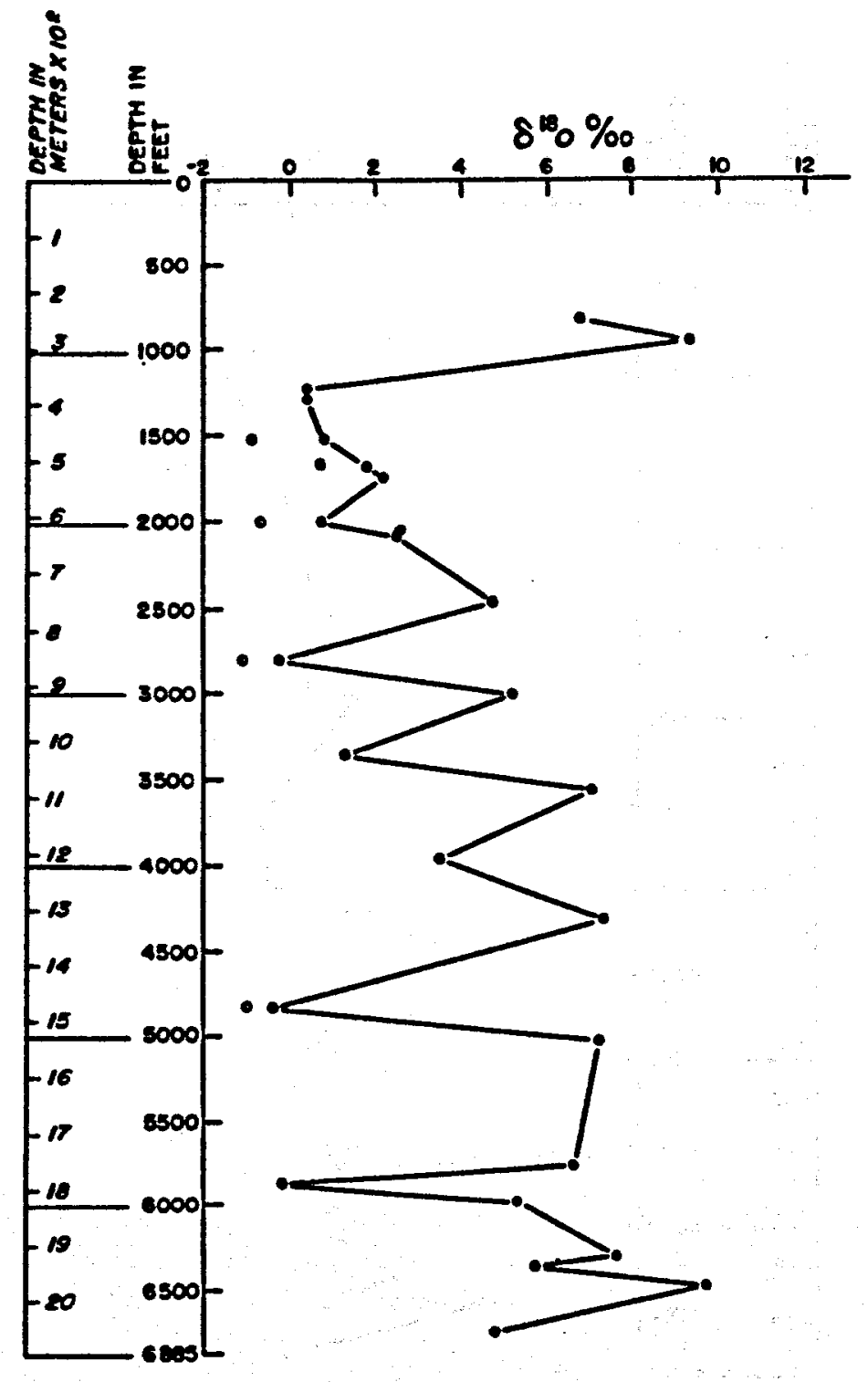

Fig. 4-1. Oxygen isotope values as a function of depth In Well $\mathrm{C} / \mathrm{T}-2$. Open clrcles are coarse samples and closed circles are powdered samples. 


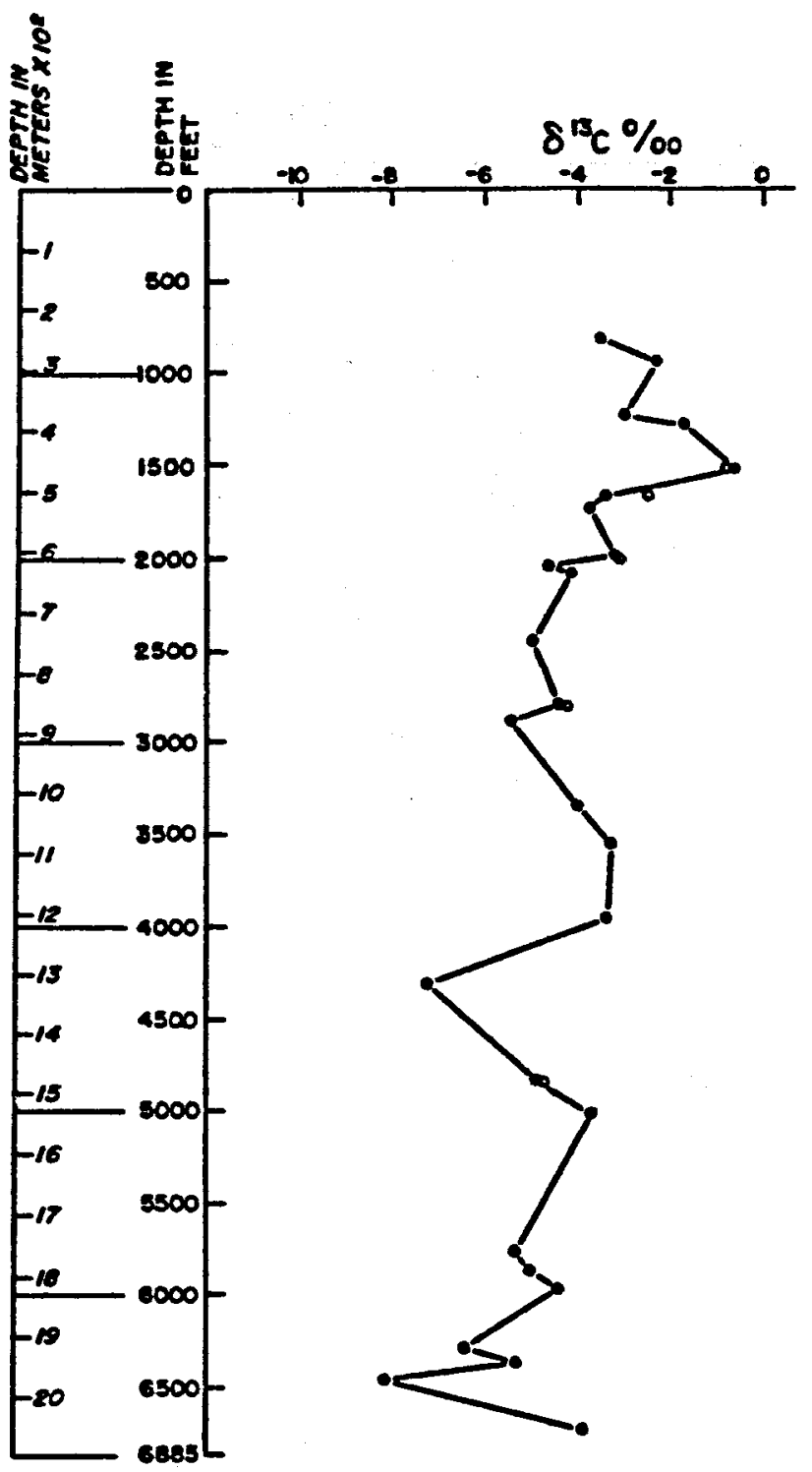

Fig.4-2. Carbon isotope values as a function of depth in Well C/T-2. Open clrcles are coarse samples and closed clrcles are powdered samples. 


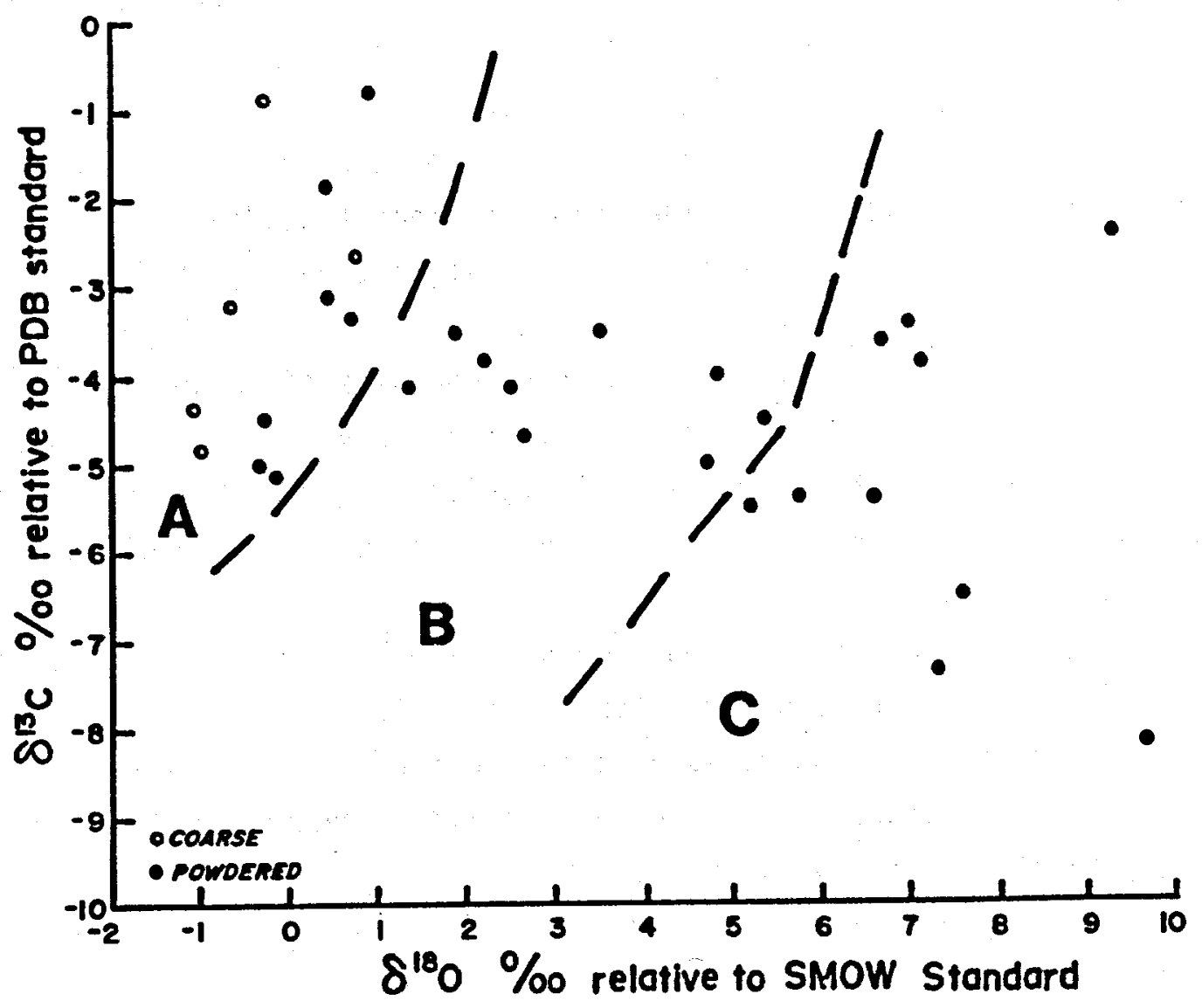

Fig. 4-3. Oxygen vs carbon isotope values from Well $\mathrm{C} / \mathrm{T}-2$. 
equivalents, whereas similar $\delta^{13} \mathrm{C}$ values were obtained for both the coarseand the fine-grained fractions.

The $\delta^{13} \mathrm{C}$ and $\delta^{18} 0$ data shown in Fig. 4-3 exhibit a general trend of decreasing $\delta^{13} \mathrm{C}$ with increasing $\delta^{18} 0$ in the calcites. This trend is opposite that typically observed in hydrothermal carbonates. For example, carbonates associated with felsic extrusives at the Tui Mine, New Zeal and (Robinson, 1974) and the Sunnyside Mine, Colorado (Casadevall and Ohmoto, 1977) display a trend of increasing $\delta^{13} \mathrm{C}$ with increasing $\delta^{18} 0$. This trend has been correlated with a decrease in the temperature of formation. The range in $\delta^{18} 0$ and $\delta^{13} \mathrm{C}$ values from these deposits is, however, similar to the range observed in $\mathrm{C} / \mathrm{T}-2$, and is typical of many hydrothermal carbonate minerals which occur in ore deposits in various types of host rock, regardless of whether or not carbonate rocks are known, or inferred, to be in the area (Bethke and Rye, 1979).

In general, the left-hand portion of the $\delta^{13} \mathrm{C}-\delta^{18} 0$ trend is composed of carbonates found in strongly altered zones (Zone A, Fig. 4-3). The central portion of the plot is comprised of carbonates from moderate-to-weakly altered rocks (Zone B), whereas the right-hand segment is characterized by carbonates from weakly altered lithologies (Zone $C$ ).

\section{Discussion}

The interpretation of data given in Table 4-I and plotted in Figs. 4-1, 4-2, and 4-3 is hindered by several factors which include: (1) our inability at present to evaluate isotopically various generations of calcite, (2) lack of fluid inclusions that could be analyzed to ascertain the isotopic composition of fluids in equilibrium with the alteration phases, and (3) our poor understanding of the temporal relationship between the present-day fluid and the alteration assemblages. Although these obstacles cannot be immediately overcome, the evaluation of the data distribution, application of geothermometers, and correlation of calculated temperatures with measured temperatures and trace element distribution patterns may aid in quantifying the hydrothermal processes that affected C/T-2.

1. Frequency Distribution. The oxygen and carbon isotopic data given in Table 4-I are graphically depicted in the form of frequency histograms in Fig. 
4-4. This plot shows that the oxygen isotopic data are composed of two distinct populations, whereas the carbon isotopic data are confined to one population. The oxygen isotope population I contains carbonates that occur above about $915.0 \mathrm{~m}(3000 \mathrm{ft})$ in the zone of moderate-to-strong alteration. Population II consists of carbonates from below $915.0 \mathrm{~m}$ in the zone of weak alteration.

Vastly different temperature regimes could explain the split of $\delta^{18_{0}}$ values into two populations. However, one might also expect a similar split in the $\delta^{13} \mathrm{C}$ values. A more plausible alternative might be the presence of different types of water, where $\delta^{18} 0$ fluid values varied, but the $\delta^{13} \mathrm{C}$ fluid composition remained essentially constant. Superimposed on this behavior could be slightly different temperatures not nearly so drastic as those required to produce the split in the populations. The break between these two $\delta^{18} 0$ groups appears to coincide with the position of the low-angle fault, which cuts the well at about $838.0 \mathrm{~m}$. The upper plate is badly brecciated and more permeable than the lower plate, thereby permitting greater access by downward percolating ground waters.

Application of the chloride-enthalpy mixing model (Fournier, 1979) to the C/T-2 fluid (analysis 1, Table 3-IV) indicates that approximately $33 \%$ mixing with a cold-water component is likely. If we assume that the bulk of this mixing occurs above the fault, and that a $\delta^{18} 0$ value of -12.6 observed in Well 14-2 (unmixed) a few miles away is typical of the deep fluid and $-15.7^{\circ} / 00$ is representative of cold ground water, a mixed fluid $\delta{ }^{18} 0$ of about $-13.7 \%$ is computed. We might conclude from this that below the fault, a $\delta^{18} 0$ fluid value of about $-12.6^{\circ} / 00$ dominates, while above the fault, a value of $-13.7^{\circ} / 00$ prevails. The presence of one $\delta^{13} \mathrm{C}$ population for the carbonates suggests that the $\delta^{13} \mathrm{C}$ value of the fluid varied little and probably averaged around $-7 \%$, typical of many ground waters (Ohmoto and Rye, 1979).

2. Isotope Geothermometry. If we assume that these $\delta^{18_{0}}$ and $\delta^{13} \mathrm{C}$ fluid values are reasonable, then temperatures of formation for the carbonates can be computed using isotope geothermometry. The application of isotope geothermometry depends on the establishment of equilibrium between the fluid and the phase being deposited. Thus, in the system calcite-water, the oxygen 


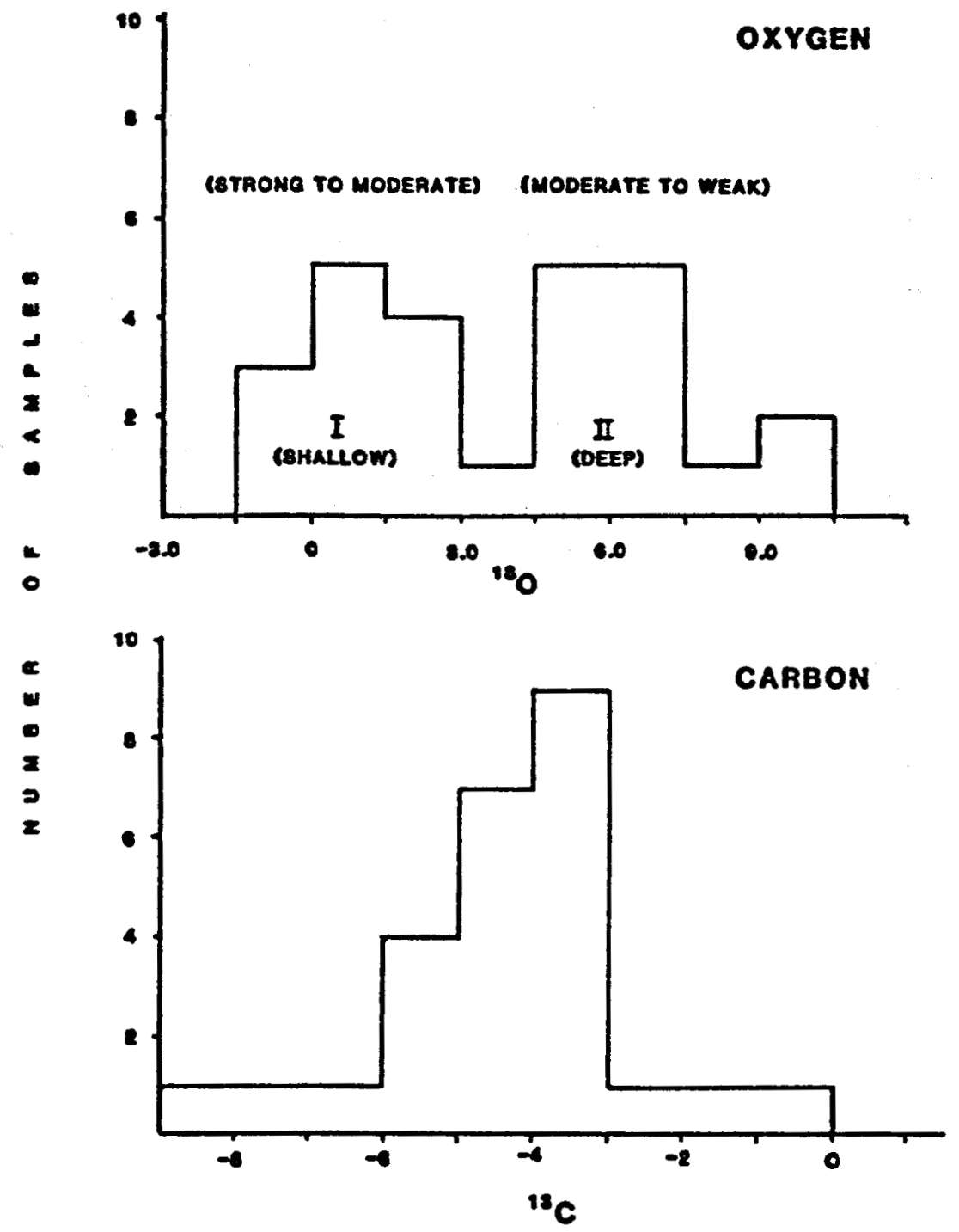

Fig. 4-4. Frequency histograms of oxygen and carbon isotope values from Well $\mathrm{C} / \mathrm{T}-2$. 
and carbon isotopic fractionation factors can be defined as:

$$
\begin{aligned}
& \alpha_{c c-w}^{0}=\frac{\left({ }^{18} 0 /{ }^{16} 0\right) c c}{\left({ }^{18} 0 /{ }^{16} 0\right) w} \quad \text { and } \\
& \alpha_{c c-w}^{0}=\frac{\left({ }^{13} c /{ }^{12} c\right) c c}{\left({ }^{13} c /{ }^{12} c\right) w} \text {, respectively. }
\end{aligned}
$$

The fractionation factor $(\alpha)$ is related to the equilibrium constant $(K)$ of the appropriate isotopic exchange reaction in the following way,

$$
\alpha=k^{1 / n}
$$

where $n$ is the number of exchanged atoms.

Note that from the definition of $\alpha$ given previously, that

$$
\ln \alpha_{c c-w}=\ln \left(1+\frac{\delta_{c c}}{1000}\right)-\ln \left(1-\frac{\delta_{w}}{1000}\right)
$$

which simplifies to: $10001 n \alpha_{c c}{ }_{w}$, with $\delta_{c c}$ and $\delta_{w}$ representing either $\delta^{18} 0$ or $\delta^{13} c$ values. The fractionation factor $(\alpha)$ has been shown to be a function of $1 / T^{2}$ and relationships have been derived from the experimental calibration of calcite-water isotopic exchange to give:

$$
10001 n \alpha_{c c}-w=2.78\left(10^{6}\right) / T^{2}-2.89
$$

for oxygen (Friedman and $\mathrm{O}^{\prime} \mathrm{Neil}, 1977$ ) and from theoretical work by Bottinga (1968) for carbon:

$$
\left.1000 \ln \alpha_{c c^{-} w}=-8.914\left(10^{8}\right) / T^{3}+8.557\left(10^{6}\right) / T^{2}+-18.11\left(10^{3}\right) / T+8.2\right)
$$

taken from Ohmoto and Rye (1979). Temperature in these equations is in kelvin. Therefore, by relating the difference between $\delta^{18} 0$ or $\delta^{13} \mathrm{C}$ values 
of carbonates and water in C/T-2 with these expressions, the temperatures of formation can be determined.

Temperatures estimated in this manner are given in Table 4-II and plotted in frequency histogram form in Fig. 4-5. The two distinct populations present in the $\delta^{18} 0$ raw data (Fig. 4-4) are now replaced by one population with a mean temperature somewhat less than the mean predicted for the carbon isotopic temperature distribution. The oxygen isotopic temperatures never exceed about $170^{\circ} \mathrm{C}$, while carbon isotopic temperatures reach as high as $240^{\circ} \mathrm{C}$ in the deeper part of the well. Little can be said about the validity of these temperatures because the fluid isotopic data is assumed and not measured. In a very general way, carbon isotopic temperatures increase with depth, while oxygen isotopic temperatures exhibit distinctive highs and lows that seem to alternate back and forth with depth. The oxygen isotopic temperatures are generally less than the measured temperatures except in the upper part of the wel 1, 304.8-594.4 m (1000-1950 ft).

\section{E. Identification of Fluid Entries}

A graphical comparison of the oxygen and carbon isotopic temperature profiles with $\mathrm{Pb}$ distribution is shown in Fig. 4-6. The enrichments of $\mathrm{Pb}, \mathrm{As}$ or $\mathrm{Hg}$ over some background concentration have generally been correlated with permeable, fluid entries in the rock. Many of the oxygen isotopic temperature spikes correlated quite closely with the highs observed in these trace elements. This is particularly true for oxygen and $\mathrm{Pb}$ below about $1200 \mathrm{~m}$ $(4000 \mathrm{ft})$. Typically, carbon isotopic temperatures do not correlate with trace element highs. Rather, they mimic, in a gross way, the present temperature distribution in the system.

These data suggest that the oxygen isotopic compositions of carbonates may have continually re-equilibrated with fluids moving through the system. Carbon isotopes, on the other hand, have retained their initial values fixed at the time of deposition. This hypothesis fits in well with experimental isotopic exchange rate data, which predict much faster rates of exchange for oxygen than carbon. This trend, coupled with the possibility that the $\mathrm{CO}_{2}$ concentration in the fluid may have decreased significantly since the deposition of the carbonates, would result in a case where the ${ }^{13} \mathrm{C}$ values remain essentially unchanged. This is substantiated to a certain degree by 
TABLE 4-II

ESTIMATES OF CARBON AND

OXYGEN ISOTOPIC TEMPERATURES

IN WELL $C / T-2$

\section{DEPTH
INTERVAL}

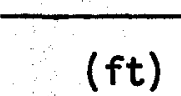

$775-790$

$905-920$

$1180-1195$

$1210-1240$

$1465-1480$

$1615-1630$

$1690-1705$

$1945-1960$

$2005-2020$

$2020-2035$

$2410-2420$

$2740-2750$

$2830-2840$

$3290-3300$

$3490-3500$

$3890-3900$

$4240-4250$

$4760-4770$

$4940-4950$

$5690-5700$

$5790-5800$

5890 - 5900

6220 - 6230

$6280-6290$

$6370-7380$

$6650-6660$

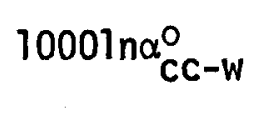

(m)

$236.2-240.8$
$275.8-280.4$
$359.7-364.2$
$368.8-378.0$
$446.5-451.1$
$492.3-496.8$
$515.1-519.7$
$592.8-597.4$
$611.1-615.7$
$615.7-620.3$
$734.6-737.6$
$835.2-838.2$
$862.6-865.6$
$1002.8-1005.8$
$1063.8-1066.8$
$1185.7-1188.7$
$1292.4-1295.4$
$1450.8-1362.5$
$1505.7-1508.8$
$1734.3-1737.4$
$1764.8-1767.8$
$1795.3=1798.3$
$1895.9-1989.9$
$1914.1-1917.2$
$1941.6=1944.6$
$2026.9-2030.0$

$275.8-280.4$

.7 - 364.2

446.5 - 451.1

$492.3-496.8$

$611.1-615.7$

$615.7-620.3$

$835.2-838.2$

$862.6-865.6$

$1002.8-1005.8$

$1063.8-1066.8$

$1185.7-1188.7$

$1292.4-1295.4$

$1450.8-1362.5$

$1505.7-1508.8$

$1734.3-1737.4$

1795.3 - 1798.3

$1895.9-1989.9$

1941.6 - 1944.6

20.4

14.

14.1

15.5

15.9

14.4

16.3

16.2

18.4

13.4

18.9

13.5

19.2

15.7

19.5

11.8

19.4

18.8

12.0

17.5

19.8

17.9

21.9

17.0

NOTE:

Assumed a $\delta^{18} 0_{w}=-13.7$ above $3000 \mathrm{ft}$

a $\delta^{18} 0_{w}=-12.6$ below $3000 \mathrm{ft}$

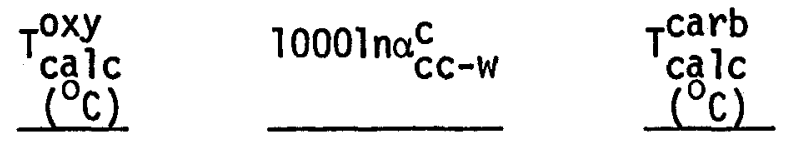

70

55

132

132

117

110

130

105

107

90
140

140

85
140

83

112

80

160

82

86

160

98

78

94

64
102

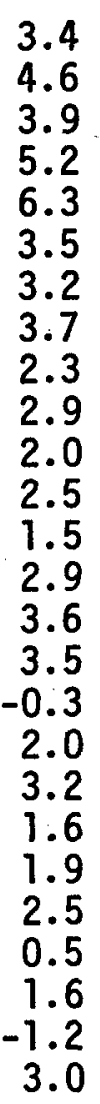

111

90

103

82
67

110

115

107

133

120

140

130

150

120

108

110

200

140

115

148

142

130

175

148

240

119 

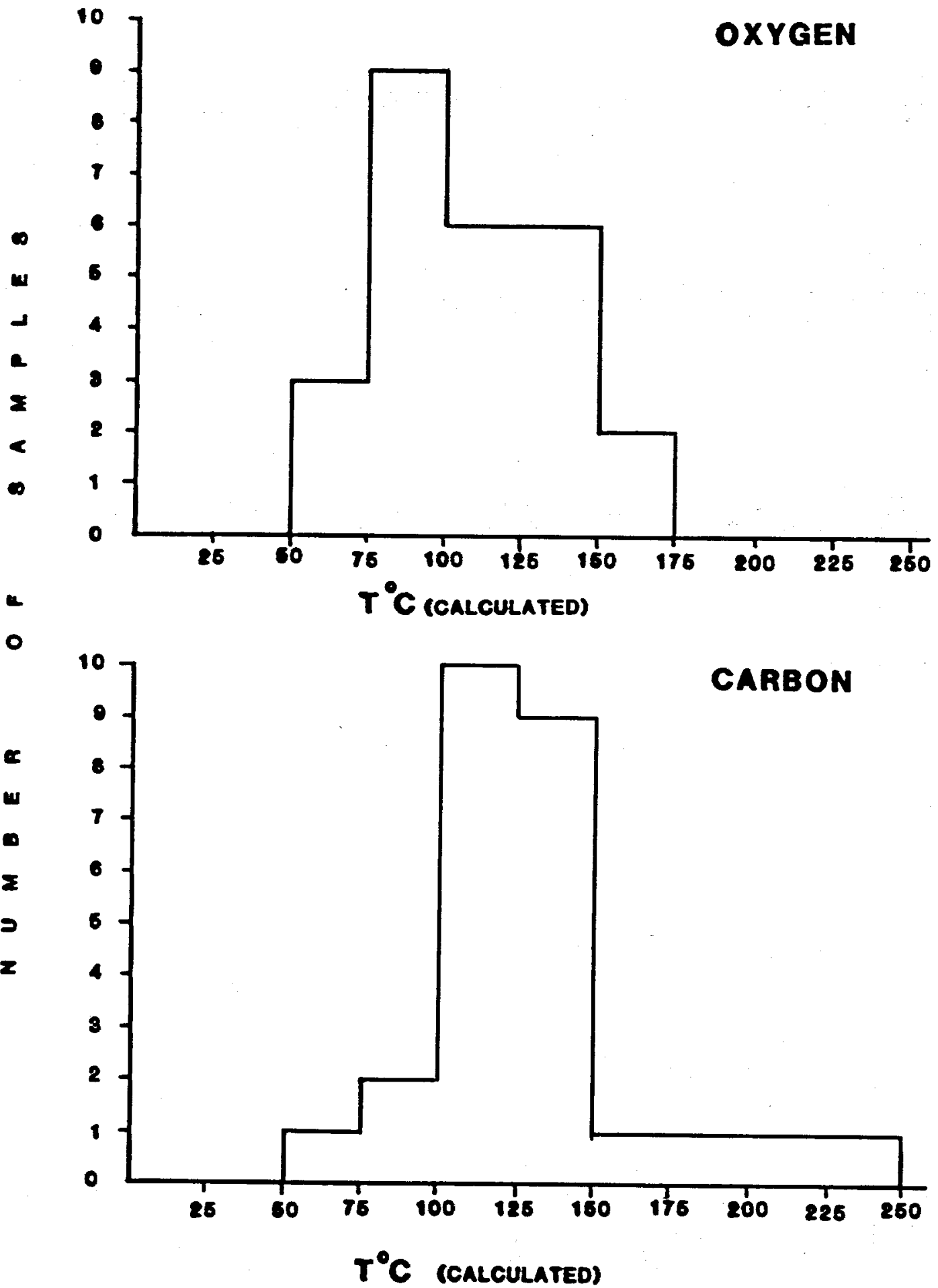

Fig. 4-5. Frequency histograms of temperatures calculated from oxygen and carbon isotope values from Well C/T-2. 


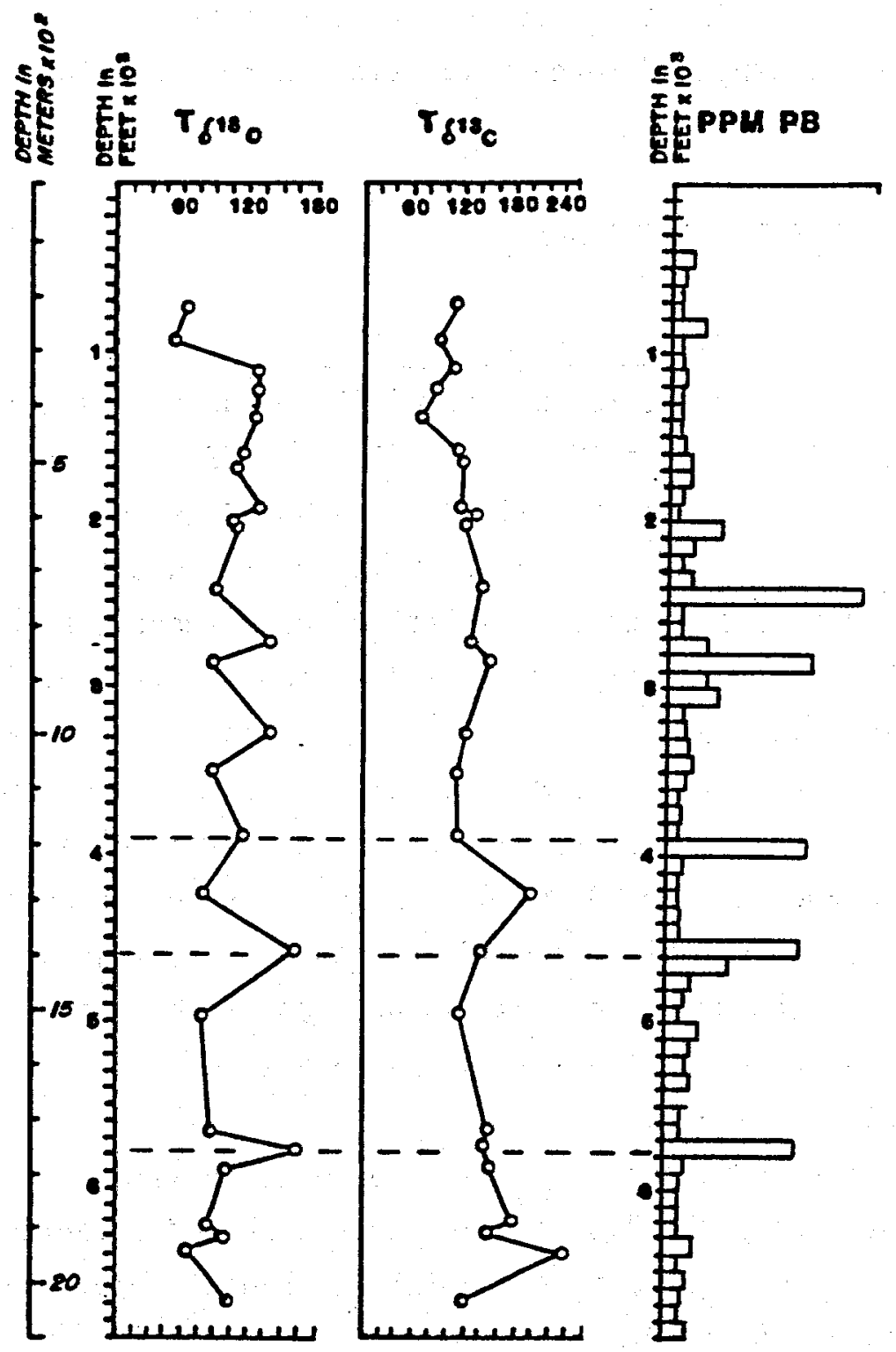

Fig. 4-6. Calculated oxygen and carbon isotoplc temperatures plotted against lead values from Well $\mathrm{C} / \mathrm{T}-2$. 
the fact that coarse- and fine-grained carbonates have essentially the same $\delta^{13} \mathrm{C}$ values, indicating the presence, through time, of a uniform $\delta^{13} \mathrm{C}$ value in the fluid and absence of re-equilibration in response to variations in temperature.

\section{PHYSICAL PROPERTY MEASUREMENTS}

A. Bulk Density and Magnetic Susceptibility

Bulk density and magnetic susceptibility measurements were obtained for 335 cuttings samples between $122 \mathrm{~m}(400 \mathrm{ft})$ and $2092 \mathrm{~m}(6885 \mathrm{ft})$ in Well $\mathrm{C} / \mathrm{T}-2$ (Table 5-I). Magnetic susceptibility was measured using. a Bison Susceptibility Bridge (Model 3101) and bulk density was determined by fluid displacement and sample weight. The latter measurement was quite difficult because the chip size was very small, which made it difficult to saturate the volume of grains with water. Trapped air would lower any density measurements. Every effort was made to eliminate this problem.

The magnetic susceptibility values ranged between 40 and $200 \times 10^{6} \mu \mathrm{cgs}$ in the alluvium and between 50 and $6000 \times 10^{6} \mu \mathrm{cgs}$ in the crystalline rocks. No clear, general correlation is evident between lithology and magnetic susceptibility, although the highest values tend to be associated with the microdiorite and Precambrian gneisses, which are rocks containing the highest per cent of mafic minerals.

The bulk density values indicate a correlation with rock type. The more mafic rocks, primarily the biotite-pyroxene-hornblende diorite and hornblende microdiorite, are more dense than the felsic granitic rocks such as the hornblende, biotite granite.

Figure $5-1$ is a plot of density versus magnetic susceptibility and indicates increasing density correlates with an increase in magnetic susceptibility. This result is due to the higher density of magnetite and the fact that the mafic minerals, which have higher densities, have higher magnetic susceptibilities.

\section{B. Thermal Conductivity}

Thermal conductivity values were obtained on 59 cuttings samples from $\mathrm{C} / \mathrm{T}-2$, between $213.4 \mathrm{~m}(700 \mathrm{ft})$ and $2075.7 \mathrm{~m}(6810 \mathrm{ft})$ and are listed in Table 
TABLE 5-I

MAGNETIC SUSCEPTIBILITIES AND DENSITIES OF CUTTINGS FROM WELL C/T-2

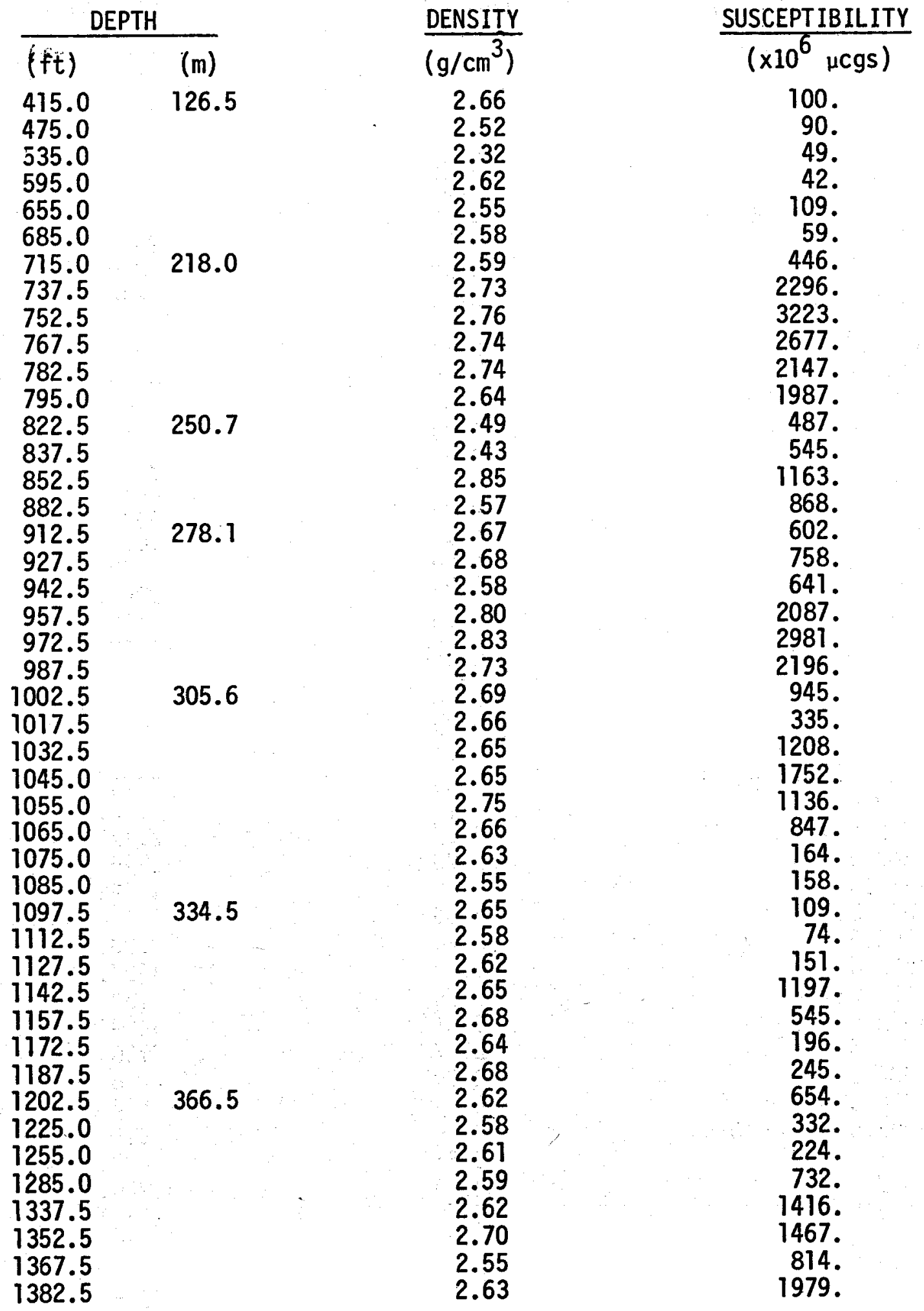


TABLE 5-I (cont.)

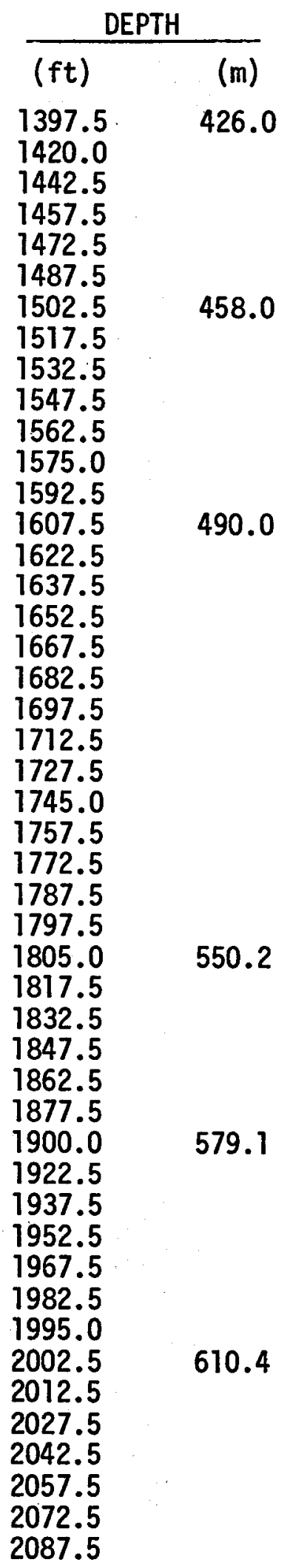

$\frac{\text { DENSITY }}{\left(\mathrm{g} / \mathrm{cm}^{3}\right)}$

2.68

2.60

2.65

2.73

2.63

2.61

2.56

2.80

2.68

2.64

2.73

2.60

2.78

2.95

2.79

2.84

2.76

2.82

2.74

2.80

2.77

2.75

2.82

2.92

2.76

2.72

2.71

2.75

2.77

2.63

2.70

2.68

2.89

2.74

2.82

2.76

2.81

2.77

2.74

2.66

2.65

2.61

2.73

2.72

2.85

2.70

2.81
MAGNETIC

SUSCEPT IBILITY

$$
\text { ( } \times 10^{6} \text { ucgs) }
$$

1764.

1155.

1115.

2184.

2139.

1484.

2385.

2922.

2039.

536.

3975.

1795.

6365.

7607.

5964.

6119.

2247.

4357.

3080 .

2880.

3096.

3165 .

3407.

3328.

2689.

2670 .

1221.

3979 .

4283.

2742.

2435.

4749 .

3856 .

4206.

4597.

4153.

4469.

3790 .

4246 .

884.

818.

488.

3756.

2854.

3355.

3618.

4246. 
TABLE 5-I (cont.)

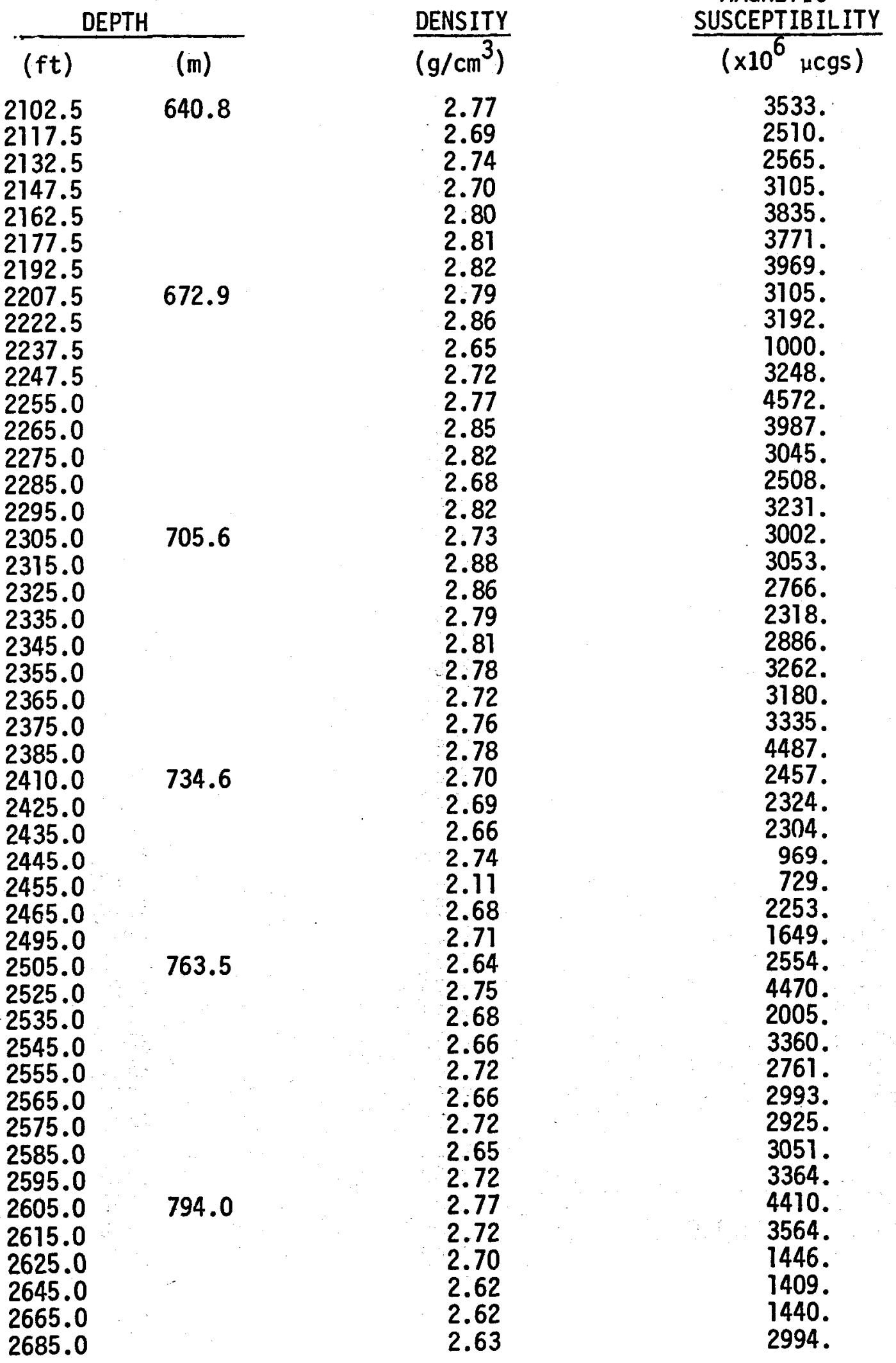

MAGNETIC SUSCEPTIBILITY ( $\times 10^{6} \mu \mathrm{cgs}$ )

3533.

2510 . 2565 . 3105 . 3835 . 3771 . 3192.

1000 .

4572. 3987. 3045 . 2508. 3231 . 3002 . 2766. 2318. 2886 . 3335 . 4487. 2457. 2324. 2304 . 969. 729. 2253. 4470 . 2005. 3360 . 2761 . 2993. 2925. 3051 . 3364 . 4410 . 3564 . 1446 . 1440. 2994. 
TABLE 5-I (cont.)

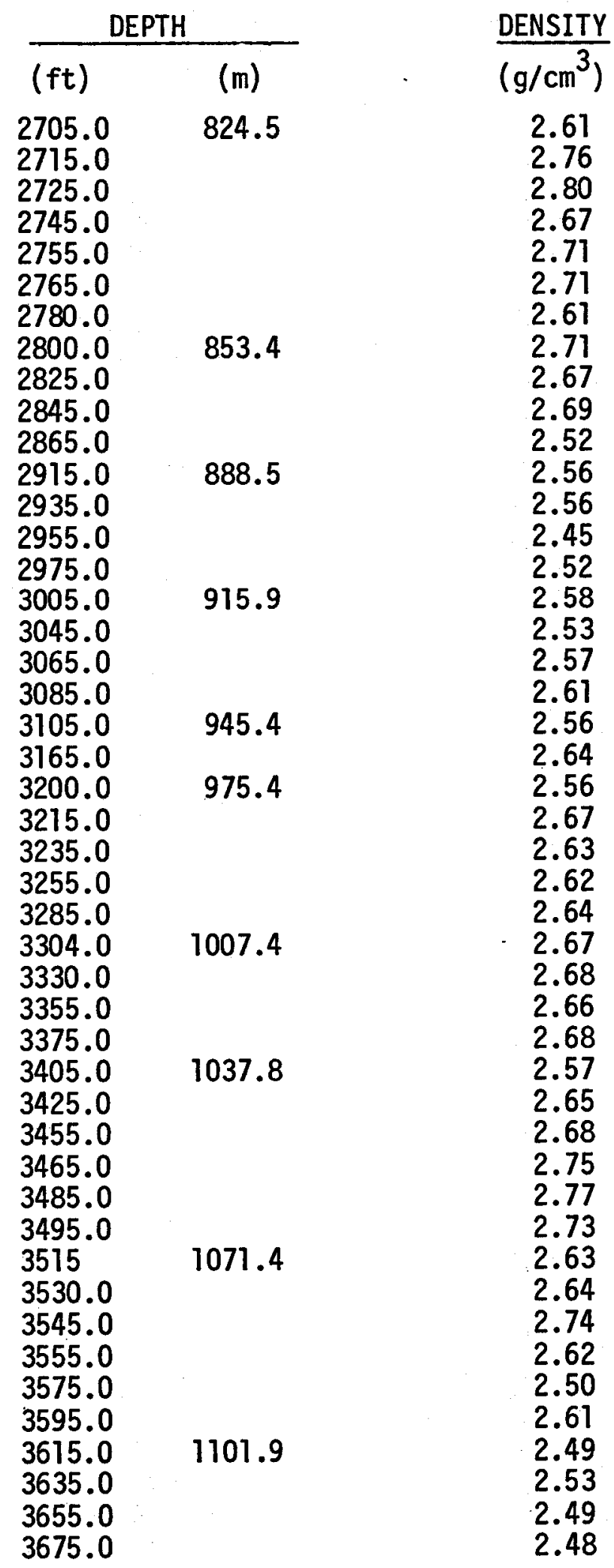

MAGNETIC SUSCEPTIBIL ITY $\left(\times 10^{6} \mu \mathrm{cgs}\right)$

3900.

2718. 2849. 2400 . 2582. 2374. 1976. 2210. 946. 787. 787. 891. 1294. 1414. 2108. 1616. 1316. 2074. 1450. 1413. 3389. 1520. 1862. 2134. 3313. 2938. 1678. 1953. 2144 . 2178. 3340 . 1701. 5421. 7050 . 3422. 3249. 2614. 2608. 2406. 2050. 1315. 892. 889. 1279. 1102. 1262. 
TABLE 5-I (cont.)

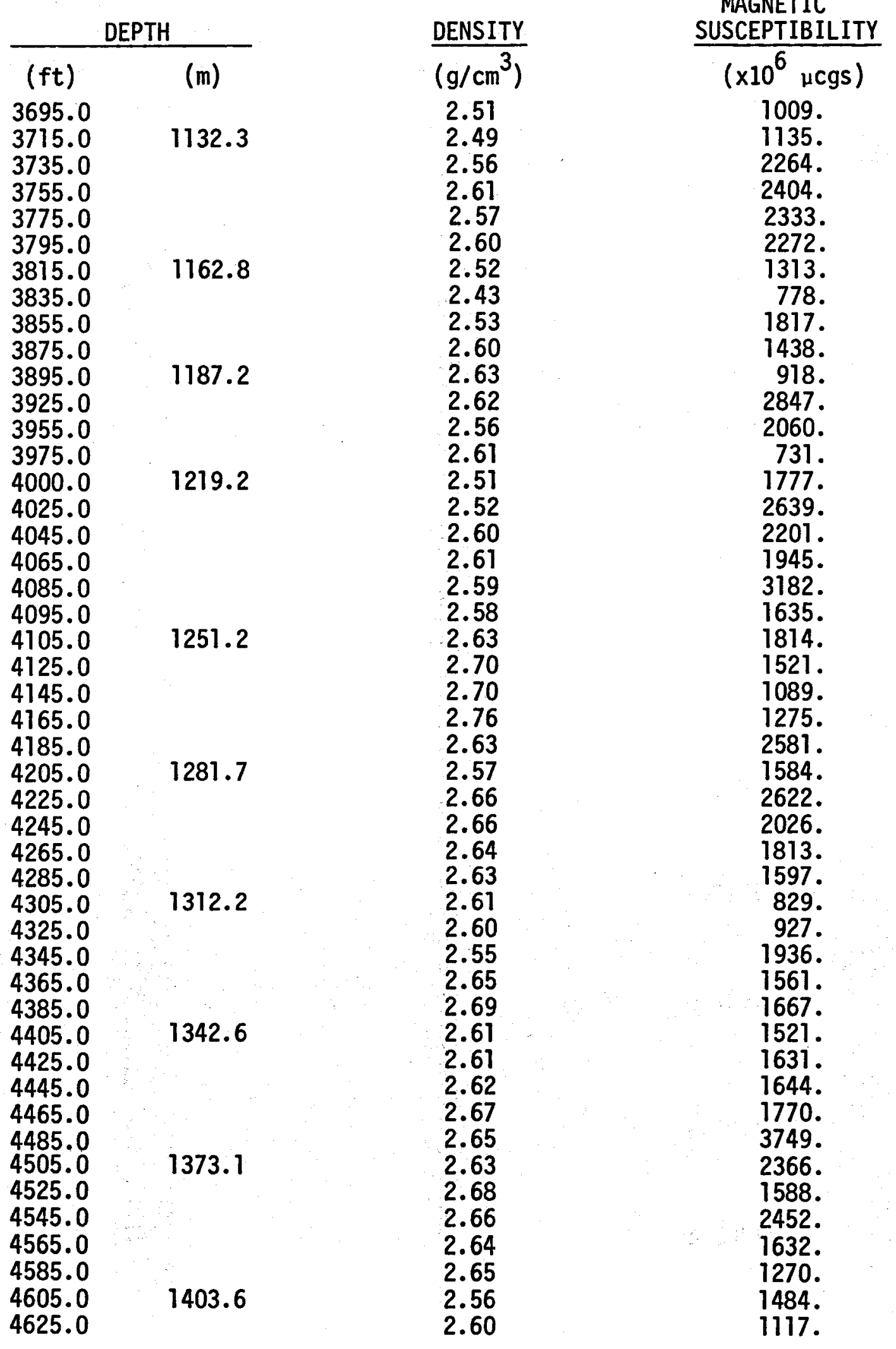


TABLE 5-I (cont.)

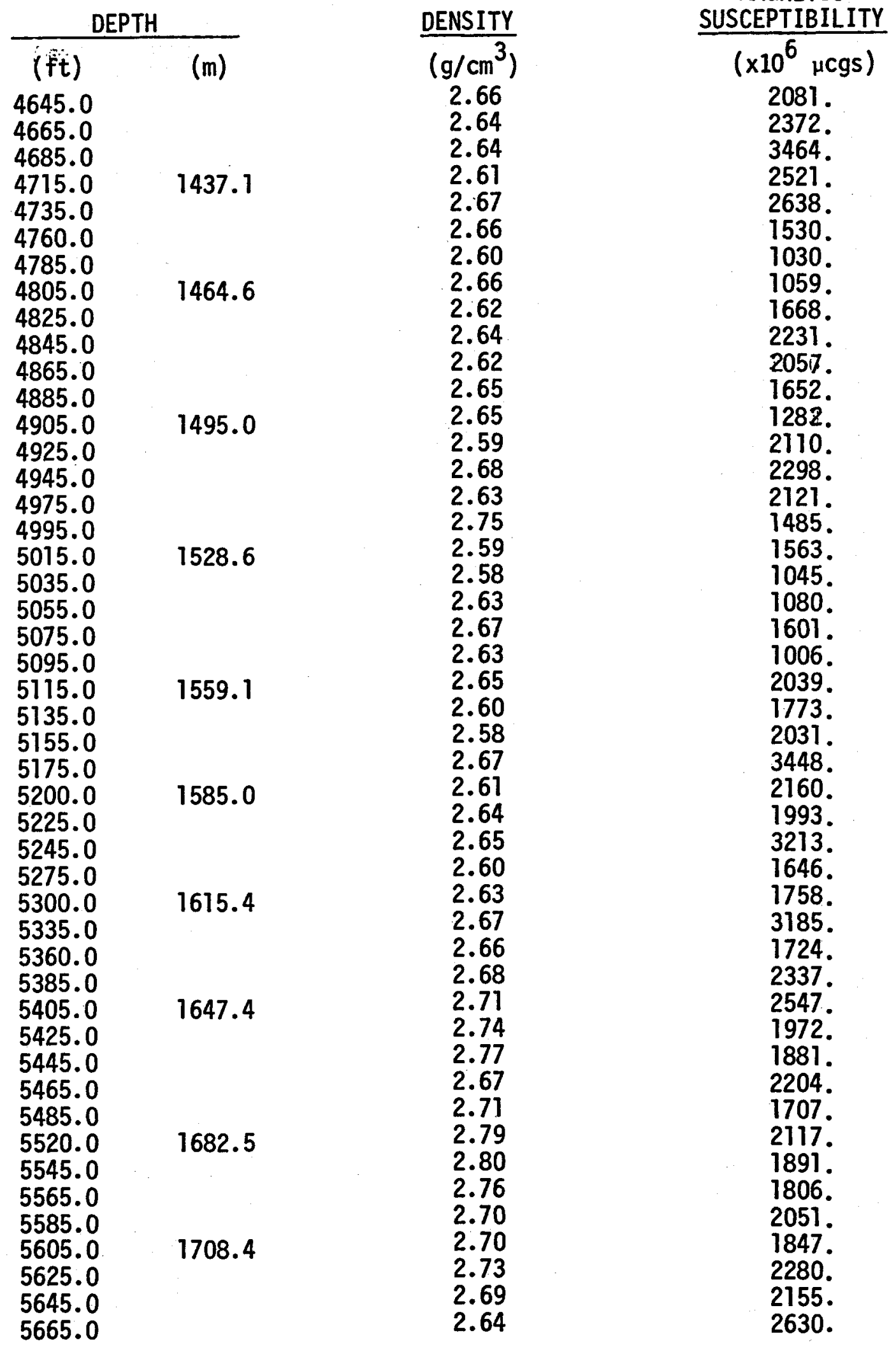

MAGNETIC USCEPTIBIL ITY$$
2081 .
$$$$
2372 .
$$$$
3464 .
$$$$
2538^{\circ}
$$$$
1530 \text {. }
$$$$
1030 .
$$$$
1059 .
$$

1668.

2231

2057.

1652.

1282.

2298.

2121.

1563.

1045.

1080.

1601

1006 .

2039.

1773.

2031.

1993.

3213.

1646.

1758.

1724.

2337.

2547.

1972.

1881.

2204.

1707.

$2171^{\circ}$

1806.

2051.

1847.

2155 .

2630 . 
TABLE 5-I (cont.)

\begin{tabular}{|c|c|c|c|}
\hline \multicolumn{2}{|c|}{ DEPTH } & \multirow{2}{*}{$\frac{\text { DENSITY }}{\left(\mathrm{g} / \mathrm{cm}^{3}\right)}$} & \multirow{2}{*}{$\frac{\text { SUSCEPTIBILITY }}{\left(\times 10^{6} \mu \mathrm{cgS}\right)}$} \\
\hline$(\mathrm{ft})$ & (m) & & \\
\hline $\begin{array}{l}5685.0 \\
5705.0 \\
5725.0 \\
5750.0 \\
5775.0 \\
5795.0 \\
5815.0 \\
5825.0 \\
5835.0 \\
5865.0 \\
5885.0 \\
5905.0 \\
5925.0 \\
5945.0 \\
5965.0 \\
5985.0 \\
6005.0 \\
6025.0 \\
6040.0 \\
6065.0 \\
6090.0 \\
6115.0 \\
6135.0 \\
6155.0 \\
6175.0 \\
6195.0 \\
6215.0 \\
6235.0 \\
6255.0 \\
6275.0 \\
6295.0 \\
6315.0 \\
6335.0 \\
6355.0 \\
6375.0 \\
6395.0 \\
6415.0 \\
6435.0 \\
6455.0 \\
6475.0 \\
6495.0 \\
6515.0 \\
6535.0 \\
6555.0 \\
6580.0 \\
6625.0\end{array}$ & 1955.3 & $\begin{array}{l}2.68 \\
2.70 \\
2.51 \\
2.71 \\
2.65 \\
2.68 \\
2.69 \\
2.70 \\
2.72 \\
2.86 \\
2.67 \\
2.77 \\
2.80 \\
2.84 \\
2.90 \\
2.73 \\
2.79 \\
2.84 \\
2.81 \\
2.79 \\
2.84 \\
2.79 \\
2.80 \\
2.79 \\
2.85 \\
2.80 \\
2.87 \\
2.87 \\
2.86 \\
2.75 \\
2.70 \\
2.85 \\
2.78 \\
2.73 \\
2.78 \\
2.85 \\
2.71 \\
2.62 \\
2.78 \\
2.74 \\
2.74 \\
2.74 \\
2.64 \\
2.67 \\
2.67 \\
2.70\end{array}$ & $\begin{array}{l}2391 . \\
1944 . \\
5478 . \\
1188 . \\
1299 . \\
1014 . \\
953 . \\
1046 . \\
2075 . \\
2673 . \\
1173 . \\
3106 . \\
1754 . \\
1276 . \\
1037 . \\
1846 . \\
968 . \\
1647 . \\
976 . \\
1697 . \\
1216 . \\
2083 . \\
2403 . \\
1831 . \\
1331 . \\
2546 . \\
1854 . \\
2461 . \\
2688 . \\
2537 . \\
958 . \\
2005 . \\
3742 . \\
1623 . \\
1799 . \\
2222 . \\
1368 . \\
1590 . \\
1181 . \\
1131 . \\
1263 . \\
1521 . \\
2231 . \\
2009 . \\
1840 . \\
2187 .\end{array}$ \\
\hline
\end{tabular}


TABLE 5-I (cont.)

\begin{tabular}{l}
\multicolumn{2}{c}{ DEPTH } \\
\hline$(\mathrm{ft}) \quad(\mathrm{m})$ \\
6650.0 \\
6665.0 \\
6685.0 \\
6705.0 \\
6725.0 \\
6755.0 \\
6785.0 \\
$6835.0 \quad 2083.3$ \\
6855.0 \\
6865.0
\end{tabular}

$\begin{array}{cc}\frac{\text { DENSITY }}{\left(\mathrm{g} / \mathrm{cm}^{3}\right)} & \text { SUSCEPTIBILITY } \\ & \left(\times 10^{6} \mu \mathrm{cgs}\right) \\ 2.67 & 1517 . \\ 2.74 & 1788 . \\ 2.81 & 1792 . \\ 2.62 & 2607 . \\ 2.73 & 2616 . \\ 2.68 & 2339 . \\ 2.77 & 2116 . \\ 2.54 & 2098 . \\ 2.58 & 2020 . \\ & 1888 .\end{array}$




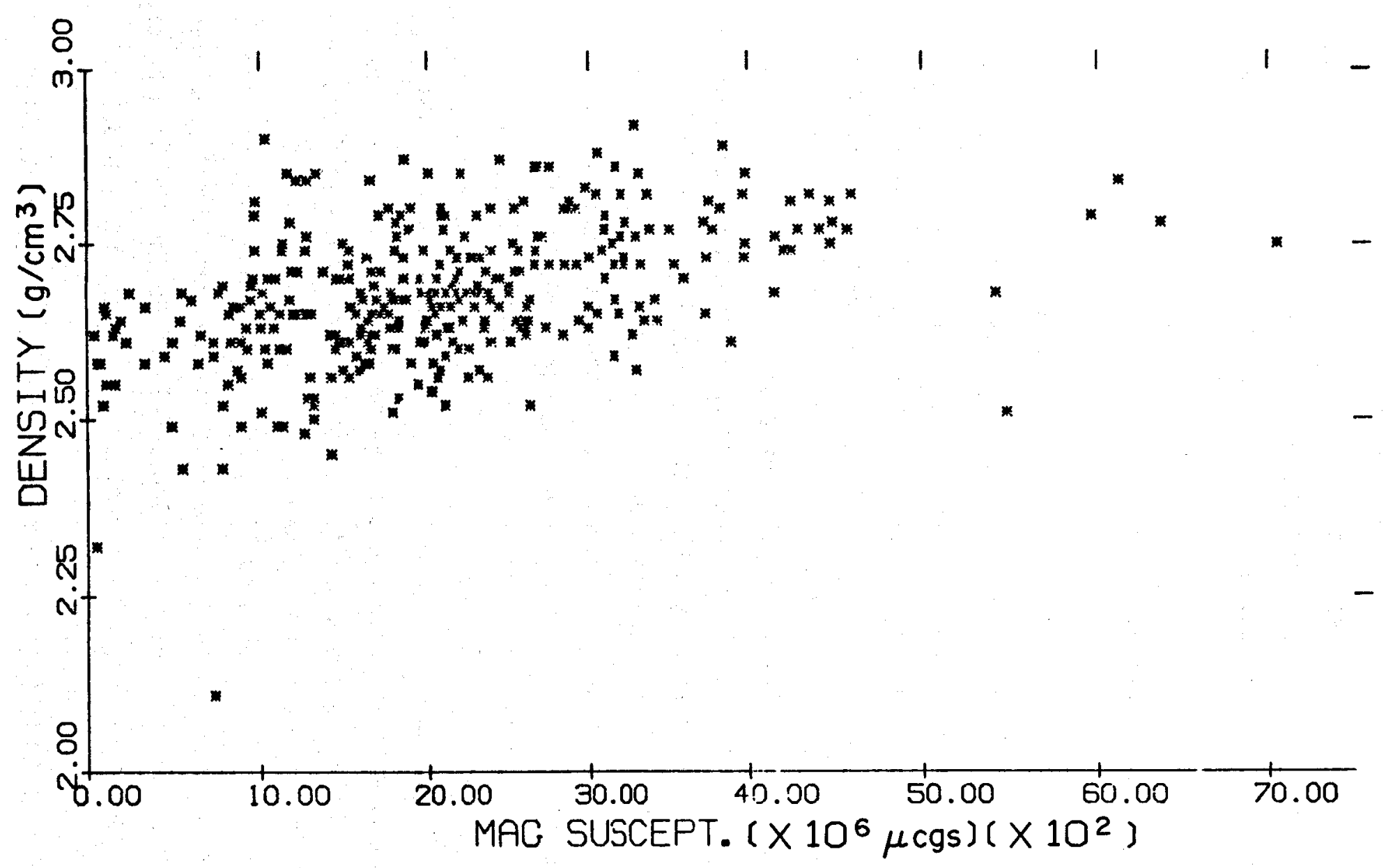

Fig. 5-1. Plot of magnetic susceptibility vs density of cuttings from Well C/T-2. 
5-II. These measurements were made on a divided bar apparatus (Sass, et al., 1971), which was calibrated with fused and crystalline quartz (Ratcliffe, 1958). Measurements were made at $15^{\circ} \mathrm{C}$ using the cell technique described by Sass et al. (1971) and adjusted for the appropriate borehole temperature using the method described by Wilson and Chapman (1980).

The temperature correction is computed using the following expression: $K_{s}^{*}=K_{0} e^{-\alpha T}$,

where

$$
\alpha=0.609 \times 10^{-3}{ }^{0} C^{-1}
$$

and $K_{0}=k_{s}^{*} e^{15 \alpha}$.

$K_{S}$ is the measured solid rock thermal conductivity at $15^{\circ} \mathrm{C}$ and $\dot{K}_{S}^{*}$ is the temperature corrected thermal conductivity at temperature $T\left({ }^{\circ} \mathrm{C}\right)$. Borehole temperatures were taken from the Dresser Atlas log of C/T-2 obtained by LASL. The sample depths, $K_{s}, T$ and $K_{s}^{*}$ are listed in Table 5-II. The thermal conductivity data are given in SI units, $\mathrm{W} / \mathrm{m}^{0} \mathrm{~K}$. To obtain cgs units, $\mathrm{mcal} / \mathrm{cm}^{\circ} \mathrm{C} \mathrm{s}$, simply multiply the data by 2.39 .

The thermal conductivities appear to be lower than might be expected. Typical values for these rock types fall between 2 and $3.5 \mathrm{~W} / \mathrm{m}^{\circ} \mathrm{K}$ (approximately). The measurements have a precision of $2 \%$ or better and an accuracy of $10 \%$ or better. However, measurements are made on chips and a mixing formula is used to convert these measurements to values for solid material. The measurement system was checked using crushed quartz standards with good results. However, C/T-2 chips are quite small and difficulties may arise from use of the mixing formula or from estimating solid material volume. The latter problem existed in the density measurements. Several experiments have been proposed and are scheduled to study the problems of estimating thermal conductivities from chip samples.

A further problem, noted earlier, is that the quartz and feldspar grains may have been crushed to such a size that these minerals were depleted in the chip samples at the time of collection and later during the washing process. The greater concentrations of mafic minerals, particularly biotite, would lower the thermal conductivity.

The data in Table 5-II would represent zero porosity material. If porosity corrections were made, the thermal conductivities would be lowered 
TABLE 5-II

THERMAL CONDUCTIVITY MEASUREMENTS ON CHIP SAMPLES FROM WELL $C / T-2$ AT $15^{\circ} \mathrm{C}$ AND WELLBORE TEMPERATURE (VALUES ARE FOR DRY, NON-POROUS ROCK)

\begin{tabular}{|c|c|c|c|c|}
\hline \multicolumn{2}{|c|}{ DEPTH } & $\mathrm{K}_{\mathrm{s}}$ & $T$ & $k_{s}$ \\
\hline$(f t)$ & (m) & $\overline{\left(W m^{-1} K^{-1}\right)}$ & $\overline{\left({ }^{0} \mathrm{C}\right)}$ & $\left(\mathrm{Wm}^{-1} \mathrm{~K}^{-1}\right)$ \\
\hline $\begin{array}{c}700-730 \\
760-775 \\
815-830 \\
920-935 \\
935-950 \\
950-965 \\
965-980 \\
980-995 \\
995-1010 \\
1010-1025 \\
1025-1040 \\
1150-1165 \\
1240-1270 \\
1345-1360 \\
1450-1465 \\
1660-1675 \\
1705-1720 \\
1750-1765 \\
1855-1870 \\
2000-2005 \\
2155-2170 \\
2250-2260 \\
2350-2360 \\
2450-2460 \\
2550-2560 \\
2710-2720 \\
2800-2810 \\
2850-2860 \\
2900-2910 \\
2950-2960 \\
3000-3010 \\
3050-3060 \\
3100-3110 \\
3150-3160 \\
3200-3210 \\
3360-3370 \\
3390-3400 \\
3450-3460 \\
3500-3510 \\
3560-3570 \\
3600-3610 \\
3650-3660 \\
3700-3710 \\
3800-3810\end{array}$ & $\begin{array}{c}213-223 \\
232-236 \\
248-253 \\
280-285 \\
285-290 \\
290-294 \\
294-299 \\
299-303 \\
303-308 \\
308-312 \\
312-317 \\
351-355 \\
378-387 \\
410-415 \\
442-447 \\
506-511 \\
520-524 \\
533-538 \\
565-570 \\
610-611 \\
657-661 \\
686-689 \\
716-719 \\
747-750 \\
777-780 \\
826-829 \\
853-856 \\
869-872 \\
884-887 \\
899-902 \\
914-917 \\
930-933 \\
945-948 \\
960-963 \\
975-978 \\
1024-1027 \\
1033-1036 \\
1052-1055 \\
1067-1070 \\
1085-1088 \\
1097-1100 \\
1113-1116 \\
1128-1131 \\
1158-1161\end{array}$ & $\begin{array}{l}2.90 \\
1.87 \\
2.79 \\
2.52 \\
2.69 \\
2.07 \\
1.94 \\
2.07 \\
1.84 \\
2.28 \\
1.84 \\
2.07 \\
2.40 \\
2.28 \\
1.87 \\
2.20 \\
1.80 \\
2.03 \\
2.10 \\
2.13 \\
2.12 \\
2.21 \\
2.13 \\
2.27 \\
1.81 \\
2.07 \\
1.76 \\
2.08 \\
1.95 \\
1.71 \\
1.90 \\
1.91 \\
1.97 \\
1.84 \\
1.78 \\
1.85 \\
1.87 \\
2.02 \\
1.77 \\
1.77 \\
1.81 \\
1.88 \\
1.91 \\
1.92\end{array}$ & $\begin{array}{l}56 \\
60 \\
70 \\
77 \\
77 \\
78 \\
79 \\
79 \\
80 \\
81 \\
82 \\
89 \\
95 \\
98 \\
103 \\
116 \\
119 \\
121 \\
125 \\
131 \\
136 \\
140 \\
143 \\
146 \\
150 \\
154 \\
156 \\
158 \\
159 \\
160 \\
161 \\
162 \\
163 \\
164 \\
165 \\
168 \\
169 \\
170 \\
170 \\
170 \\
171 \\
172 \\
173 \\
175\end{array}$ & $\begin{array}{l}2.83 \\
1.82 \\
2.70 \\
2.43 \\
2.59 \\
1.99 \\
1.87 \\
1.99 \\
1.77 \\
2.19 \\
1.77 \\
1.98 \\
2.29 \\
2.17 \\
1.77 \\
2.07 \\
1.69 \\
1.90 \\
1.96 \\
1.98 \\
1.97 \\
2.05 \\
1.97 \\
2.10 \\
1.67 \\
1.90 \\
1.62 \\
1.91 \\
1.79 \\
1.57 \\
1.74 \\
1.75 \\
1.80 \\
1.68 \\
1.62 \\
1.68 \\
1.70 \\
1.84 \\
1.61 \\
1.61 \\
1.65 \\
1.71 \\
1.73 \\
1.74\end{array}$ \\
\hline
\end{tabular}


TABLE 5-II (cont.)

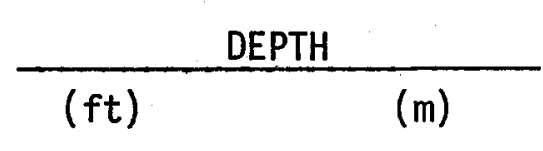

$\begin{array}{ll}4000-4100 & 1219-1250 \\ 4200-4210 & 1280-1283 \\ 4400-4410 & 1341-1344 \\ 4600-4610 & 1402-1405 \\ 4800-4810 & 1463-1466 \\ 5090-5100 & 1551-1554 \\ 5200-5210 & 1585-1588 \\ 5400-5410 & 1645-1649 \\ 5600-5610 & 1709-1710 \\ 5800-5810 & 1768-1771 \\ 6000-6010 & 1829-1832 \\ 6200-6210 & 1890-1893 \\ 6400-6410 & 1951-1954 \\ 6600-6610 & 2012-2015 \\ 6800-6810 & 2073-2076\end{array}$

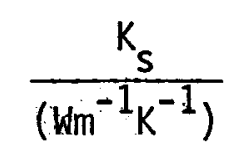

1.65
1.71
1.75
1.76
1.80
1.78
1.80
1.77
1.95
1.86
1.62
1.92
1.76
2.01
1.94

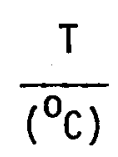

180

181

185

190

192

195

197

201

203

207

210

211

215

218

223

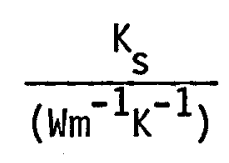

1.49

1.55

1.58

1.58

1.62

1.59

1.61

1.58

1.74

1.65

1.44

1.70

1.56

1.78

1.71 
(Plewa, 1976). However, porosity of these rocks is quite low ( $<2 \%$, with few exceptions) and the correction would be small.

\section{GEOPHYSICAL INTERPRETATION}

\section{A. Introduction}

A number of well logs have been obtained in C/T-2 by Phillips Petroleum Company (PPC) and LASL. The PPC logs are confidential and were examined but not analyzed. The LASL logs have been digitized at $0.15 \mathrm{~m}(0.5 \mathrm{ft})$ increments, plotted at 12 and $24 \mathrm{~m} / \mathrm{cm}$ (100 and $200 \mathrm{ft} / \mathrm{in.}$ ) scales and interpreted in terms of geologic and geophysical properties. The logs have been correlated, where possible, to each other and to geologic rock types.

The well was cased to $1280.1 \mathrm{~m}(4200 \mathrm{ft})$ and the casing cemented before logging by LASL. Hence the log data are not studied in detail above this depth. Unfortunately most of the interesting, varied geology occurs above $844.3 \mathrm{~m}(2770 \mathrm{ft})$, as noted earlier, and lies behind casing. A11 logs available for study are listed in Table 6-I.

Both Schlumberger (Sch1.) and Dresser Atlas (DA) natural gamma logs were recorded with the neutron logs. The caliper log was recorded with the temperature log. The electric log was obtained with an induction tool. Each $\log$ will be discussed individually and interpretations of each $\log$ and $\log$ data cross plots will be presented and discussed.

The log data have been plotted on Fig. A (inside pocket on inside back cover) at a $24 \mathrm{~m} / \mathrm{cm}(200 \mathrm{ft} / \mathrm{in.})$ scale and in the same units in which they were recorded. A lithology log and columns showing (1) altered cataclasite, gouge and microbreccia, (2) chlorite after mafic minerals, (3) estimated volume per cent sulfides and (4) estimated volume per cent "limonite" are included in Fig. A. The magnetic susceptibility and density measurements obtained from chip samples and discussed earlier are also plotted in Fig. A.

A second plot, at $12 \mathrm{~m} / \mathrm{cm}(100 \mathrm{ft} / \mathrm{in}$.$) scale for the portion of the hole$ below casing, 1280.1-2099.4 $\mathrm{m}(4200-6855 \mathrm{ft})$, has been created and is shown in Fig. B. A few of the logs shown on Fig. A have been excluded, new data added, thermal conductivity and temperature gradient have been added, and the DA neutron and density logs are shown converted to porosity and density units, respectively. 
TABLE 6-1

WELL LOGS OBTAINED IN C/T-2 BY LASL ${ }^{a}$

\begin{tabular}{|c|c|c|c|c|}
\hline Log Name & Logging Company & Log Date & $\begin{array}{l}\text { Logged Interval } \\
\text { (m) (ft) } \\
\end{array}$ & $\begin{array}{c}\text { Bottom - Hole Temperature } \\
\left({ }^{\circ} \mathrm{F}\right)\left({ }^{\circ} \mathrm{C}\right)\end{array}$ \\
\hline Diff. Temperature & Dresser Atlas & $11 / 14 / 78$ & $\begin{array}{l}0-2079.6 \\
(0-6823)\end{array}$ & $442(227.8)$ \\
\hline Gamma-Ray Neutron ${ }^{b}$ & Dresser Atlas & $11 / 16 / 78$ & $\begin{array}{l}234.7-2080.8 \\
(770-6827)\end{array}$ & $446(230.0)$ \\
\hline Comp. Densilogc & Dresser Atlas & $11 / 17 / 78$ & $\begin{array}{l}234.7-2080.2 \\
(770-6825)\end{array}$ & $443(228.3)$ \\
\hline Acoustic CBL/VDL & Dresser Atlas & $11 / 17 / 78$ & $\begin{array}{l}231.6-1767.8 \\
(760-5800)\end{array}$ & $446(230.0)$ \\
\hline Borehole Comp. Sonicd & Schlumberger & $2 / 5 / 79$ & $\begin{array}{l}1287.4-2087.8 \\
(4224-6850)\end{array}$ & $440(226.7)$ \\
\hline Induction - spe & Schlumberger & $2 / 5 / 79$ & $\begin{array}{l}1297.8-2085.9 \\
(4258-6844)\end{array}$ & $440(226.7)$ \\
\hline Gamma-Ray Neutron $f$ & Schlumberger & $2 / 5 / 79$ & $\begin{array}{l}243.8-2089.0 \\
(800-6854)\end{array}$ & $440(226.7)$ \\
\hline
\end{tabular}

NOTES: aWe11 was cased to $1280.1 \mathrm{~m}(4200 \mathrm{ft})$ for all logs.

bThermal Neutron - NT-N, 130.

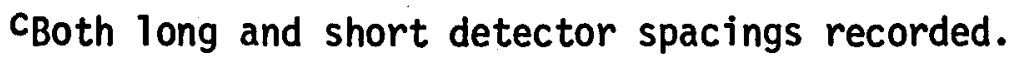

d'3-ft spacing for single received $\Delta T$; 5-ft spacing for variable density.

esingle Induction log - 6FF40.

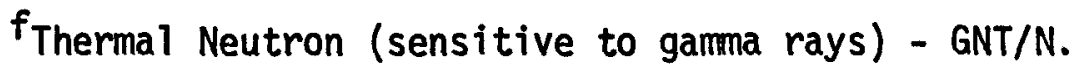

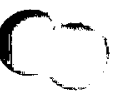


Reference to Figs. A and B will be made frequently in following sections. All data recording parameters were in English and/or 0il Field units. SI and the original units are both shown on Fig. $A$ and $B$ as they will be throughout the rest of this report.

\section{B. $\quad$ Log Descriptions}

1. Temperature Log. DA recorded their Differential Temperature Log in $\mathrm{C} / \mathrm{T}-2$ at $30.5 \mathrm{~m} / \mathrm{min}(100 \mathrm{ft} / \mathrm{min})$. The $\log$ was run down the hole and a caliper log was recorded simultaneously. Both absolute temperature and a differential temperature log were recorded. Only the absolute temperature log has been digitized and it is plotted in Fig. A. Temperature gradients have been computed from this $\log$ using 3.05 and $15.3 \mathrm{~m}$ (10 and $50 \mathrm{ft}$ ) depth intervals, and are plotted in Fig. B.

A curious feature of the temperature $\log$ is the several, quite smooth near-zero gradient intervals throughout the log; examples can be noted between 472.4 and $499.9 \mathrm{~m}(1550$ and $1640 \mathrm{ft}$ ) and between 823.0 and $883.9 \mathrm{~m}$ (2700 and $2900 \mathrm{ft}$ ). Either these intervals reflect instrument malfunction or tool sticking in the borehole (see discussion of caliper tool). Although many of these zero gradient temperature intervals occur in casing, tool sticking would be the most probable cause of these features. An earlier PPC temperature log does not exhibit any similar features and the DA tool did fail at the bottom of the hole before any post survey calibration or repeat run could be made.

The computed temperature gradient exhibits larger variations in the $\mathbf{3 . 0 5}$ $\mathrm{m}$ (10 ft) interval values than in the $15.3 \mathrm{~m}(50 \mathrm{ft})$ interval values. These variations cannot be completely explained by thermal conductivity changes (see Fig. B). Remember that the thermal conductivity measurements are for zero porosity rock and that thermal conductivity decreases with increasing porosity. Note that the low-temperature gradient interval between 1630.7 and $1691.6 \mathrm{~m}$ (5350 and $5550 \mathrm{ft}$ ) correlates with a low, near-zero neutron porosity. Below $1706.9 \mathrm{~m}(5600 \mathrm{ft})$ the neutron porosity correlates with a temperature gradient increase. The neutron porosity reflects the presence of both porosity and hydrous minerals and both would lower the thermal conductivity and increase the gradient. 
2. Caliper Log. The DA caliper log was recorded simultaneously with the temperature log. Several abrupt, unexplained recording offsets occurred in the caliper $\log$ and these were removed before the data were plotted in Fig. A. A bad splicing job on the $\log$ and spring and/or electrical problems with the tool could explain these offsets. The log was recorded moving down the hole. The caliper may not have been fully open which could may have caused the tool to stick in the hole. This combination caliper-temperature tool is not a good combination tool (M. Mathews, personal communication). The caliper part probably sticks the sonde going down the borehole as the temperature log is being recorded, giving false gradient and temperature recording. Electrical problems really began in this tool about 1740.4 to $1761.7 \mathrm{~m}$ (5710 to $5780 \mathrm{ft}$ ) and it totally failed at the bottom of the hole (TD) for both the temperature and caliper. Therefore, no log (temperature or caliper) was recorded coming out of the borehole.

Similar temperature-caliper problems were recorded using DA in Well C/T-1 (Mesa 31-1). All cased caliper logs showed an increase in borehole size as the log was recorded going downhole. The caliper log was correct when the log was recorded coming out of the borehole; it verified casing size (M. Mathews, personal comm.). Temperature gradients of near-zero were also recorded in 31-1, which indicated the tool was sticking. A temperature log recorded coming out of the borehole showed no near-zero temperature gradients for C/T-1 (Mesa 31-1). Unfortunately for $\mathrm{C} / \mathrm{T}-2$ the tool (temperature-caliper) failed at TD and no log could be obtained coming out of the borehole. The log shows insignificant hole enlargement or caving that might indicate fracture intercepts in the wellbore. Fault gouge was noted in drill chips in intervals centered at $1453.9 \mathrm{~m}(4770 \mathrm{ft})$ and $1767.8 \mathrm{~m}(5800 \mathrm{ft})$ and neither interval has generated any hole enlargement, which suggests both fractured intervals are well sealed.

The caliper log shows a decreasing hole size with depth in casing and an increasing hole size with depth in the open hole. A temperature effect should result in only a single type of variation such as an increase in apparent hole diameter with depth. Note, too, that the casing depth is clearly lower on the caliper log than reported by PPC. This discrepancy appears on nearly all the logs and indicates a depth recording problem in the logging of $C / T-2$. This problem will be discussed further in a later section. 
3. Acoustic (Velocity) Logs. LASL obtained a Sch1. Borehole Compensated Sonic Log (BHC) and a DA Acoustic Cement Bond Log (VDL) in $C / T-2$. The Schr. log contains a $\Delta t$ measurement using a single, $3 \mathrm{ft}(.91 \mathrm{~m})$ spacing receiver, an amplitude measurement and a variable density (wave form peaks), $5 \mathrm{ft}$ (1.53 $\mathrm{m})$ spacing, measurement. The $\Delta t$ and amplitude log data are reproduced in Fig. A.

The Schl. $\log$ was recorded only in the open hole. The BHC log exhibits only minor problems of cycle skipping. However, the tool did experience a transmitter failure below $1944.6 \mathrm{~m}(6380 \mathrm{ft})$ and data were lost between 1944.6 and $1966.0 \mathrm{~m}$ ( 6380 and $6450 \mathrm{ft}$ ). A second transmitter in the tool was used successfully thereafter. Notes on the log indicate a switch was made to keying on the third, $E_{3}$, rather than the first, $E_{1}$, positive peak at $1834.3 \mathrm{~m}$ $(6018 \mathrm{ft})$ and that the $\Delta t$ data are invalid (no reason given) between 1318.3 and $1325.9 \mathrm{~m}$ ( 4325 and $4350 \mathrm{ft}$ ). The $\Delta t$ curve shifts to longer travel times between 1834.3 and $1925.7 \mathrm{~m}$ ( 6018 and $6318 \mathrm{ft}$ ) due to a change in peak detection, $E_{1}$ to $E_{3}$.

The tool was centralized and pulled at $15.2 \mathrm{~m} / \mathrm{min}$ ( $50 \mathrm{ft} / \mathrm{min}$ ). No transmitter-receiver separations were reported on the log; however, Schl. people indicated that this log operated with a three-foot spacing for the travel time $\log$ and five-foot spacing for the VDL log.

Using a single transmitter-receiver combination to compute acoustic velocity is not particularly accurate. Errors due to timing, non-centralized tool, and hole shape cannot be ascertained or removed. Two-receiver or two-transmitter and four-receiver combinations on tools have been developed to alleviate these errors.

The Sch1. BHC sonic tool, which is a two-transmitter, four-receiver tool, can be used inside casing as a cement bond log. In this application a single transmitter is used and a travel time $10 \mathrm{~g}$ is recorded from the near $(3 \mathrm{ft})$ receiver and a variable density $\log$ is recorded from the far $(5 \mathrm{ft})$ receiver. Also, the amplitude of the first positive $\left(E_{1}\right)$ or third positive $\left(E_{3}\right)$ peak is recorded from the far receiver. In open hole applications this $\log$ can be used to locate fractures. The acoustic velocity can be computed using the arrival time and the transmitter-receiver spacing of three feet. A velocity of $5300 \mathrm{ft} / \mathrm{s}(1.62 \mathrm{~km} / \mathrm{s})$ for the borehole fluid, a borehole diameter of $8.5 \mathrm{in}$. $(21.6 \mathrm{~cm})$ and a tool diameter of $33 / 8 \mathrm{in} .(8.6 \mathrm{~cm})$ were constants used in the 
computation. Refraction of the acoustic wave at the borehole rock interface was included in the computatuion. The computed interval transit time is shown in Fig. B.

Fig. 6-1 shows a section of both the DA and Schl. variable density acoustic logs. The logs have been shifted in depth to align what we believe are identical events; the depth shift used was approximately $33 \mathrm{ft}(10 \mathrm{~m})$, downhole for the DA acoustic log. Four events, probably produced by fractures, are noted by arrows in the figure; the fracture at $4768 \mathrm{ft}(1453.3$ m) (Schl. $\log$ depth), on the basis of gouge and cataclasite in the chip samples, has been identified as a fault. The scale on the DA $10 \mathrm{~g}$ is 300 to $1160 \mathrm{~s}$ and on the Schl. $\log$ is 200 to $1200 \mathrm{~s}$, left to right in both cases. Note that the first positive peak (light trace) on the Schl. log is barely visible and only noticable in a few places. The first arrival is the compressional wave and the shear wave arrives some time later. One way to identify the shear wave arrival on the VDL (Kowalski, 1975) is a change in slope on the bands. The shear wave arrival appears to be the fifth white band, and averages about 240 s later than the first arrival on the DA $10 g$.

4. Neutron Logs. Both a DA thermal neutron $\log (\mathrm{N}-\mathrm{TN})$ and a Schl . thermal neutron $\log (G N T-N)$ were obtained in $C / T-2$. The DA log was obtained at $10.7 \mathrm{~m} / \mathrm{min}(35 \mathrm{ft} / \mathrm{min}$ ) and a time constant of $2 \mathrm{~s}$ and the $\mathrm{Sch} 1 . \log$ was obtained at $18.3 \mathrm{~m} / \mathrm{min}(60 \mathrm{ft} / \mathrm{min}$ ) and time constant of $1 \mathrm{~s}$. The $\mathrm{Sch} 1$. $\log$ is sensitive to gamma rays as well as thermal neutrons. Both logs were recorded in API units although the DA log scale was calibrated for an air-filled hole and labeled as $\mathrm{N}-\mathrm{TN} / \phi$ units. A simple multiplication of the DA neutron $\log$ scale by 12 converts it to the correct API units, as noted on Fig. A. The corrected $\log$ is plotted in Fig. B. Clearly the logs from the two companies do not compare favorably. First, there is a depth offset, which will be discussed later, between the two logs; second, the DA log exhibits a much greater variability than the Schl. log although changes in response are coincident (allowing for the depth offset); and third, the Schl. log response in the open hole is beyond the limit of the calibration curve (much less than 1\% porosity) for this tool given in Sch1. (1972) whereas the DA tool response is largely within the calibration range shown on their calibration graph (Dresser Atlas, 1980). Figures 6-2, 6-3, and 6-4 are cross plots of data from 


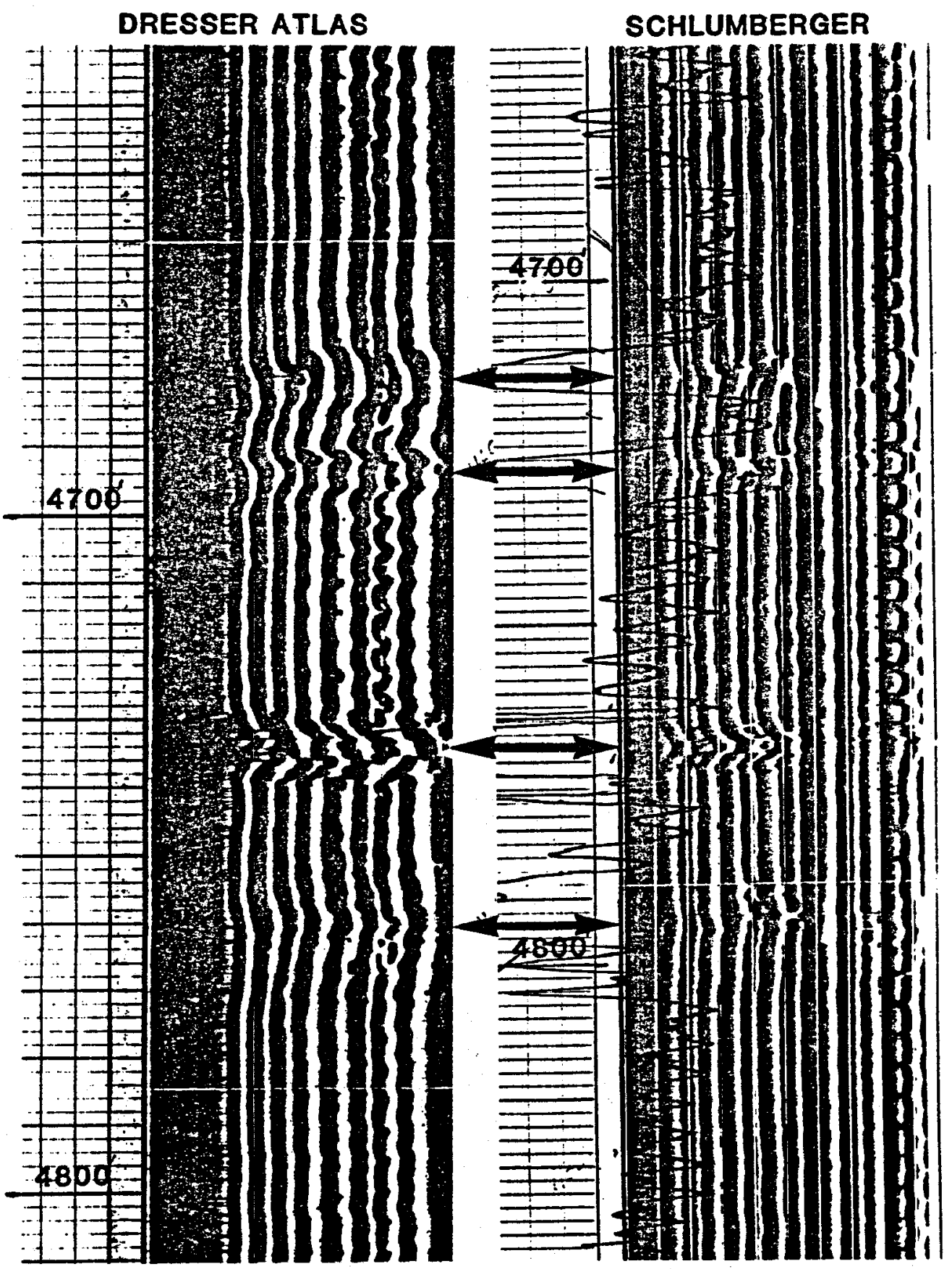

Fig. 6-1. Varlable density acoustic logs - 


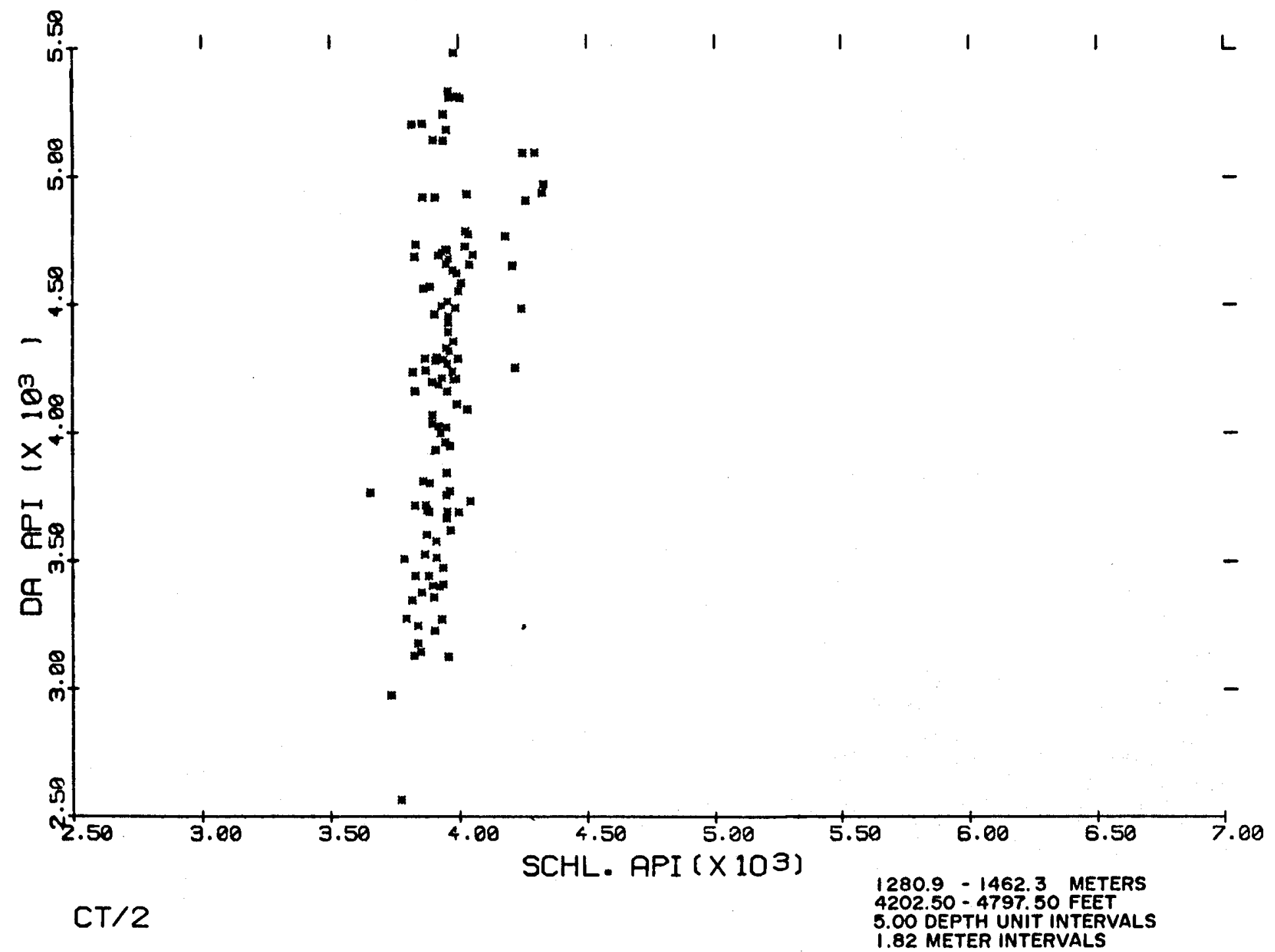

Fig. 6-2. Dresser-Atlas vs Schlumberger neutron . 


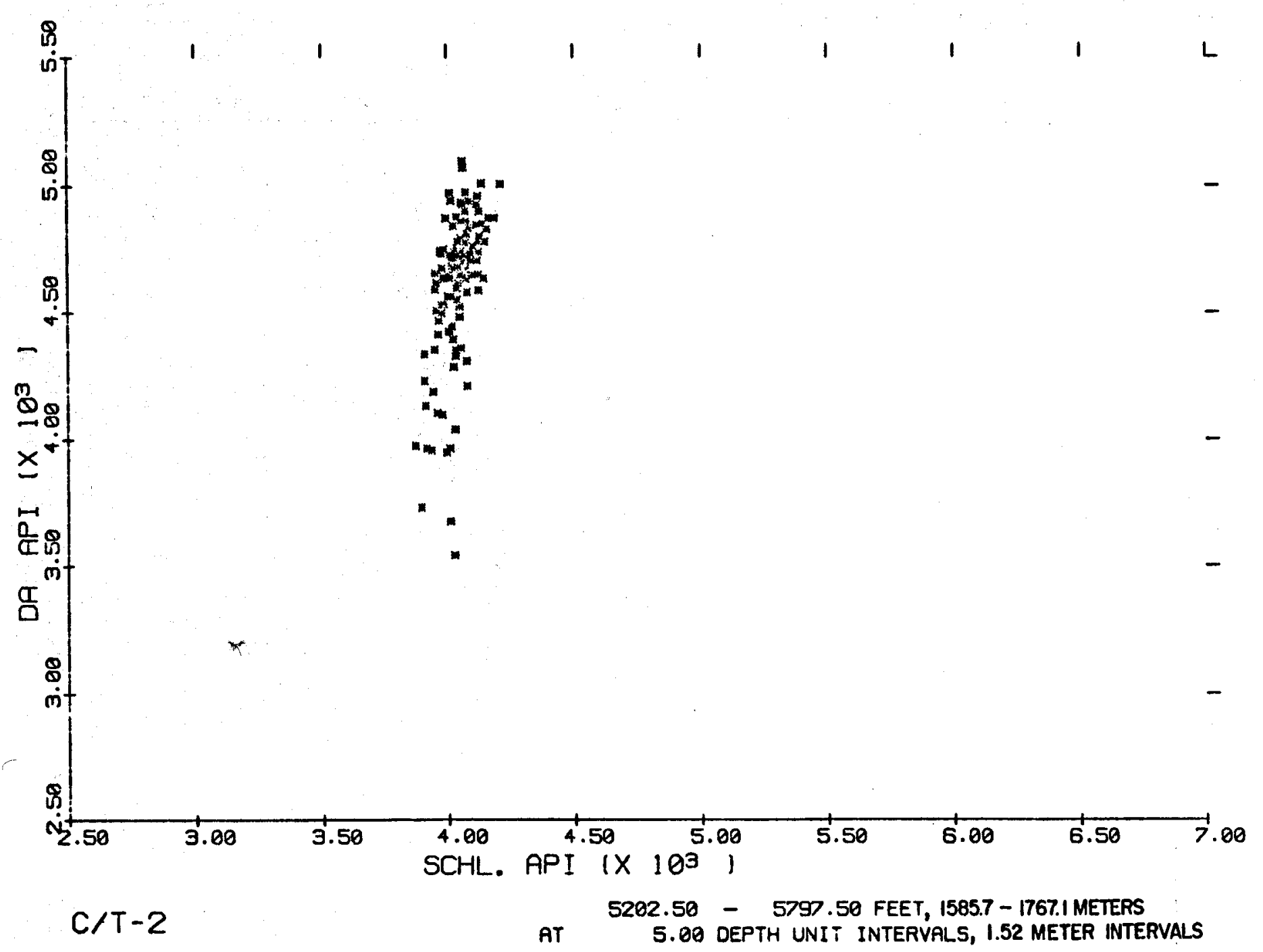


占

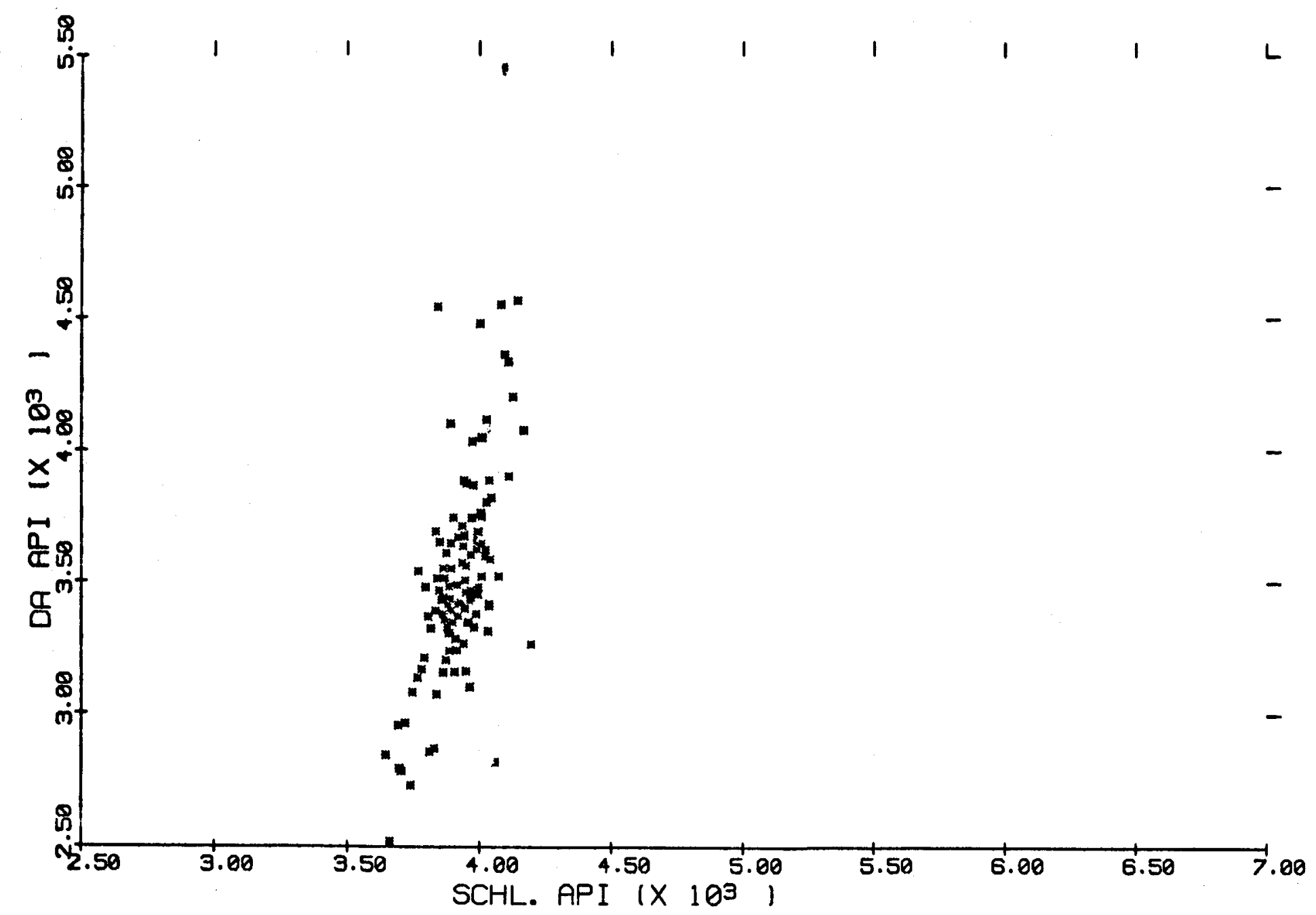

C/T-2

- 5797.50 FEET, 18905 - 20719 METEPS 5.00 DEPTH UNIT INTERVALS, 1.52 METER INTERVALS

Fig. 6-4. Dresser -Atlas ve Schlumberger neutron. 
the two neutron logs for three arbitrarily selected intervals. The data have been averaged on $1.52 \mathrm{~m}(5 \mathrm{ft})$ intervals. The Sch1. GNT-N tool which uses a Geiger-Mueller detector, is sensitive to both thermal neutrons and gamma rays. The tool is not commonly used for quantitative porosity measurements. The DA N-TN tool, which uses a Helium-3 detector, is sensitive primarily to thermal neutrons. A summary comparison for the two tools and their use in Well $\mathrm{C} / \mathrm{T}-2$ is given in Table 6-II.

TABLE 6-II

COMPARISON OF THE TWO NEUTRON TOOL SPECIFICATIONS

AND LOGging PARAMETERS IN WELL $\mathrm{C} / \mathrm{T}-2$

\begin{tabular}{|c|c|c|c|c|c|c|c|c|c|c|}
\hline Tool & Source & Detector & $\begin{array}{c}\text { G.R. } \\
\text { Sensi- } \\
\text { tivity }\end{array}$ & Spacing & $\begin{array}{l}\text { Tool } \\
\text { Dia. }\end{array}$ & $\begin{array}{l}\text { Togging } \\
\text { Speed }\end{array}$ & $\overline{T C}$ & Units & $\begin{array}{l}\text { Bore- } \\
\text { hole } \\
\text { Fluid }\end{array}$ & $\begin{array}{l}\text { Temp. } \\
\text { Rating }\end{array}$ \\
\hline $\begin{array}{l}\text { Schl. } \\
\text { 6NT-N }\end{array}$ & $\begin{array}{l}4 \mathrm{Cl} \\
\text { AmBe }\end{array}$ & GM & High & $\begin{array}{l}16 \mathrm{in} . \\
40.6 \mathrm{~cm}\end{array}$ & $\begin{array}{l}25 / 8 \mathrm{in} \\
6.7 \mathrm{~cm} \\
\end{array}$ & $\begin{array}{l}60 \mathrm{ft} / \mathrm{min} \\
18.3 \mathrm{~m} / \mathrm{min} \\
\end{array}$ & $1 \mathrm{sec}$ & API & Water & $\begin{array}{l}500^{\circ} \mathrm{F} \\
260^{\circ} \mathrm{C} \\
\end{array}$ \\
\hline $\begin{array}{l}\mathrm{DA} \\
\mathrm{N}-\mathrm{TN}\end{array}$ & $\begin{array}{l}4.5 \mathrm{Ci} \\
\text { AmBe }\end{array}$ & $3 / \mathrm{He}$ & Low & $\begin{array}{l}18 \mathrm{in.} \\
45.7 \mathrm{~cm}\end{array}$ & $\begin{array}{l}3 \mathrm{in} . \\
7.6 \mathrm{~cm}\end{array}$ & $\begin{array}{l}35 \mathrm{ft} / \mathrm{min} \\
10.7 \mathrm{~m} / \mathrm{min}\end{array}$ & $2 \mathrm{sec}$ & API & Water & $\begin{array}{l}555^{\circ} \mathrm{F} \\
290^{\circ} \mathrm{C}\end{array}$ \\
\hline
\end{tabular}

Although differences in the responses of the two tools is expected, the very different response in $\mathrm{C} / \mathrm{T}-2$ is not expected. The Schl. $\log$ exhibits very little variability and only locally mimics the $D A$ log. Of the three intervals plotted, only the one between 1866.9 and $1988.8 \mathrm{~m}(6125$ and $6525 \mathrm{ft}$ ) demonstrates any significant variability in the Schl. log. A linear relationship between the two logs was determined from data in this interval to be

$$
D A=10137-3.50 \text { Schl umberger. }
$$

A third degree polynomial was fit to the DA calibration curve and was used to convert the DA $\log$ to porosity units (Table 6-III). The polynominal equation is:

$\log _{\phi}=1.72-4.86 \times 10^{-4} A-8.11 \times 10^{-11} A^{2}$,

where $A$ is in API units.

The data in Table 6-III indicate that the polynomial equation used to convert the DA neutron $\log$ from API to porosity units is quite good for the normal porosity range of rocks. The neutron porosity data are plotted in Fig. $B$, and indicate the porosity of rocks intersected by $C / T-2$ below $1280.2 \mathrm{~m}$ $(4200 \mathrm{ft})$ averages less than $4 \%$ and nowhere exceeds $8 \%$. A component of the 
TABLE 6-III

COMPARISON OF POROSITY VALUES READ FROM DA CALIBRATION CURVE AND POLYNOMIAL EQUATION

\begin{tabular}{lcc} 
API & $\begin{array}{c}\text { POROSITY } \\
(\text { GRAPH }\end{array}$ & $\begin{array}{c}\text { POROSITY } \\
\text { (CALC.) }\end{array}$ \\
\hline 300 & 40.5 & 37.5 \\
600 & 26.5 & 26.3 \\
900 & 19.2 & 19.2 \\
1200 & 13.5 & 13.7 \\
1500 & 9.6 & 9.8 \\
1800 & 7.1 & 7.0 \\
2100 & 5.2 & 5.0 \\
2400 & 3.75 & 3.6 \\
2700 & 2.75 & 2.6 \\
3000 & 1.9 & 1.8 \\
3300 & 1.3 & 1.3 \\
3520 & 1.0 & 1.0 \\
4000 &.-- & .6 \\
5000 &.-- & .2 \\
\hline
\end{tabular}


neutron porosity is due to hydrous minerals which will be demonstrated later.

5. Density Logs. LASL obtained a DA dual-spacing DENSILOG in C/T-2. The $\log$ was run at $15.2 \mathrm{~m} / \mathrm{min}(50 \mathrm{ft} / \mathrm{min})$ and a time constant of $1 \mathrm{~s}$. The detector spacings were $19 \mathrm{~cm}(7.5 \mathrm{in.})$, the short spacing, and $33 \mathrm{~cm}(13 \mathrm{in})$, the long spacing. The data were recorded in counts/min for both short- and long-spaced logs and are plotted in Fig. A. The upper portion of the long-spaced log varied widely and was not digitized. Therefore, it is not shown in Fig. A. Apparently the scales shown on the original logs are reversed. To correct this error simply divide the long-spaced data by two and multiply the short-spaced data by two. These operations are noted on Fig. A.

Based on calibration curves supplied by DA we determined the following equations to convert counts to bulk density.

Short-Spaced: $x_{D}=2.722-2.559 \log x_{C}$

(Aluminum calibrator counts: 7500 )

Long-Spaced: $\quad X_{D}=2.739-1.035 \log X_{C}$

(Aluminum calibrator counts: 11475)

where $X_{C}$ is counts and $X_{D}$ is bulk density. The log counts are first divided by the aluminum calibration counts and then used in the formula. Dennis Lynch of DA (Ventura, California) informed us that the long-spaced counts should yield the better density estimates. The bulk densities were computed using the above formulas and are plotted on Fig. B. The short-spaced values are consistently lower than would be expected for these rock types whereas the long-spaced counts appear reasonable.

Note that the densities determined from chip samples are plotted by points along with the DA bulk densities. With few exceptions, the chip values are significantly greater than those calculated from the well logs below $1623.1 \mathrm{~m}(5325 \mathrm{ft})$. Although the data do not agree, they do show the same variations. Above $1623.1 \mathrm{~m}(5325 \mathrm{ft})$ the data show better agreement. The chip densities might reflect sampling problems. A greater amount of heavier minerals may have been concentrated in the chip samples below $1623.1 \mathrm{~m}$ (5325 $\mathrm{ft}$ ). The density log may be underestimating the density of rocks high in mafics; however, this error should not be greater than several tenths of a $\mathrm{gm} / \mathrm{cc}$. Assuming no error, the difference could be explained by approximately 
$8 \%$ porosity which seems too high and is not supported by the neutron porosity values. We suspect all three factors have contributed to the discrepancy between the two measurements.

6. Electrical Conductivity and SP Logs. The Schl umberger 6FF40 induction $\mathrm{log}$, the only electric log that could be run in this hole (M. Mathews, personal communication), was run in $\mathrm{C} / \mathrm{T}-2$ at a speed of $305 \mathrm{~m} / \mathrm{min}$ $(1000 \mathrm{ft} / \mathrm{min})$. The tool was not centered, and a borehole correction of -25 millimhos was used. Both a conductivity and resistivity log were recorded and linear scales were used. An SP log was also obtained. No values of $R_{m}, R_{m f}$, or $R_{m c}$ were recorded. The logs were obtained long after the hole was completed and the borehole fluid at the time of the logging was water. The water samples analyses (Table 3-IV) indicates the borehole fluid contains approximately $6200 \mathrm{ppm}$ TDS. Using the temperature range 185 to $227^{\circ} \mathrm{C}$ (365 to $440^{\circ} \mathrm{F}$ ), observed in the drill hole between 1280.1 and $2098.5 \mathrm{~m}$ (4200 and 6885 $\mathrm{ft}$ ), the borehole fluid resistivity ranges between 0.19 and $0.15 \mathrm{ohm}-\mathrm{m}$ (Schlumberger, 1972a, p.9), and little or no contrast should exist between the borehole and formation fluid resistivities.

Schl umberger (1972b, p.31 and 1974, p.3) notes that induction logs, including the 6FF40, yield poor resolution and accuracy where formation resistivities exceed 100 ohm- $m$, and there may be a 2 mmho zero error as well. The induction log conductivity values in C/T-2 are almost entirely below 10 mmhos/m (greater than 100 ohm-m resistivity) and numerous intervals show a $2 \mathrm{mmho} / \mathrm{m}$ or lower conductivity. Also Schl. (1974, p.3) notes that the $6 \mathrm{FF} 40$ tool requires standoff for best accuracy. The casing diameter being less than the open-hole diameter precluded use of centralizers on the induction tool. Hence, the electrical resistivity (or conductivity) measurements in $\mathrm{C} / \mathrm{T}-2$ are probably inaccurate. This problem was observed in electrical logging of other Roosevelt Hot Springs wells (Glenn and Hulen, 1979). However, the tool does locate conductive fracture or fault zones.

The SP log contains a few interesting variations. The probable fault at $1453.9 \mathrm{~m}(4770 \mathrm{ft})$, and the $57.9 \mathrm{~m}(190 \mathrm{ft})$ immediately above the fault, show a right deflection (shale direction) on the log. The right deflection may reflect the presence of clay minerals in the fault intercept at $1453.9 \mathrm{~m}$ (4770 $\mathrm{ft}$ ) and the probability that the fault either parallels the drill hole over a 
$61.0 \mathrm{~m}(200 \mathrm{ft})$ interval or that the fault zone is $61.0 \mathrm{~m}(200 \mathrm{ft})$ thick. A similar, shorter response occurs opposite a probable fault at $1767.8 \mathrm{~m}$ (5800 $\mathrm{ft}$ ) and again reflects the presence of clay minerals in the fault.

Several left deflections occur between the bottom of casing at $1280.1 \mathrm{~m}$ $(4200 \mathrm{ft})$ and $1399.0 \mathrm{~m}(4590 \mathrm{ft})$. We offer no definitive explanation for these events, although permeable fractures may be responsible. The principal source of SP in the hole may be streaming potential which could indicate the fractures associated with the SP shifts are permeable.

7. Gamma-Ray Logs. Two gamma-ray logs were obtained in $\mathrm{C} / \mathrm{T}-2$, one by $\mathrm{DA}$ and one by Schl. Both logs were obtained simultaneously with the neutron logs and were recorded in API units. The Schl. $\log$ was run at $15.2 \mathrm{~m} / \mathrm{min}$ (50 $\mathrm{ft} / \mathrm{min}$ ) and a $1 \mathrm{~s}$ time constant, whereas the $D A \log$ was run at $10.7 \mathrm{~m} / \mathrm{min}$ $(35 \mathrm{ft} / \mathrm{min})$ and a $2 \mathrm{~s}$ time constant. Unlike the neutron logs, the two gamma-ray logs agree reasonably well. Both logs are shown in Fig. A and for simplicity only the DA $\log$ is shown in Fig. B. Note the depth offset between the two logs. Plots of the DA Gamma-Ray log data versus the Schlumberger Gamma-Ray log data are shown in Figs. 6-5, 6-6, and 6-7 for three arbitrary depth intervals. The data are averages over .61 $\mathrm{m}(2 \mathrm{ft})$. A forty-five degree line has been drawn in each figure for reference.

As expected, the more acidic rock units generate the highest and the more mafic rock units generate the lowest gamma-ray counts. In particular, the hornblende-biotite granite/syenite has a distinct high gamma-ray count, for example interval 1080.0 to $1249.7 \mathrm{~m}$ ( 3540 to $4100 \mathrm{ft}$ ), and the hornblende-biotite granodiorite has a distinct low gamma-ray count, for example 804.6 to $1079.0 \mathrm{~m}$ (2640 to $3540 \mathrm{ft}$ ). The gamma-ray log has been used routinely for lithologic identification in igneous and metamorphic rocks in base mineral logging (Glenn and Nelson, 1977).

The high counts over short intervals, such as seen at $1920.2 \mathrm{~m}(6300 \mathrm{ft})$, are attributed to anomalous values of uranium, thorium and/or their daughters in these intervals. Geochemical analyses presented earlier for 1920.2-1923.3 $m(6300-6310 \mathrm{ft})$ substantiate this conclusion. We noted earlier that the anomalous contributions at $1920.2 \mathrm{~m}(6300 \mathrm{ft})$ were from thorium, and uranium and thorium daughters. The uranium has been largely depleted. 
్ㅗㅇ

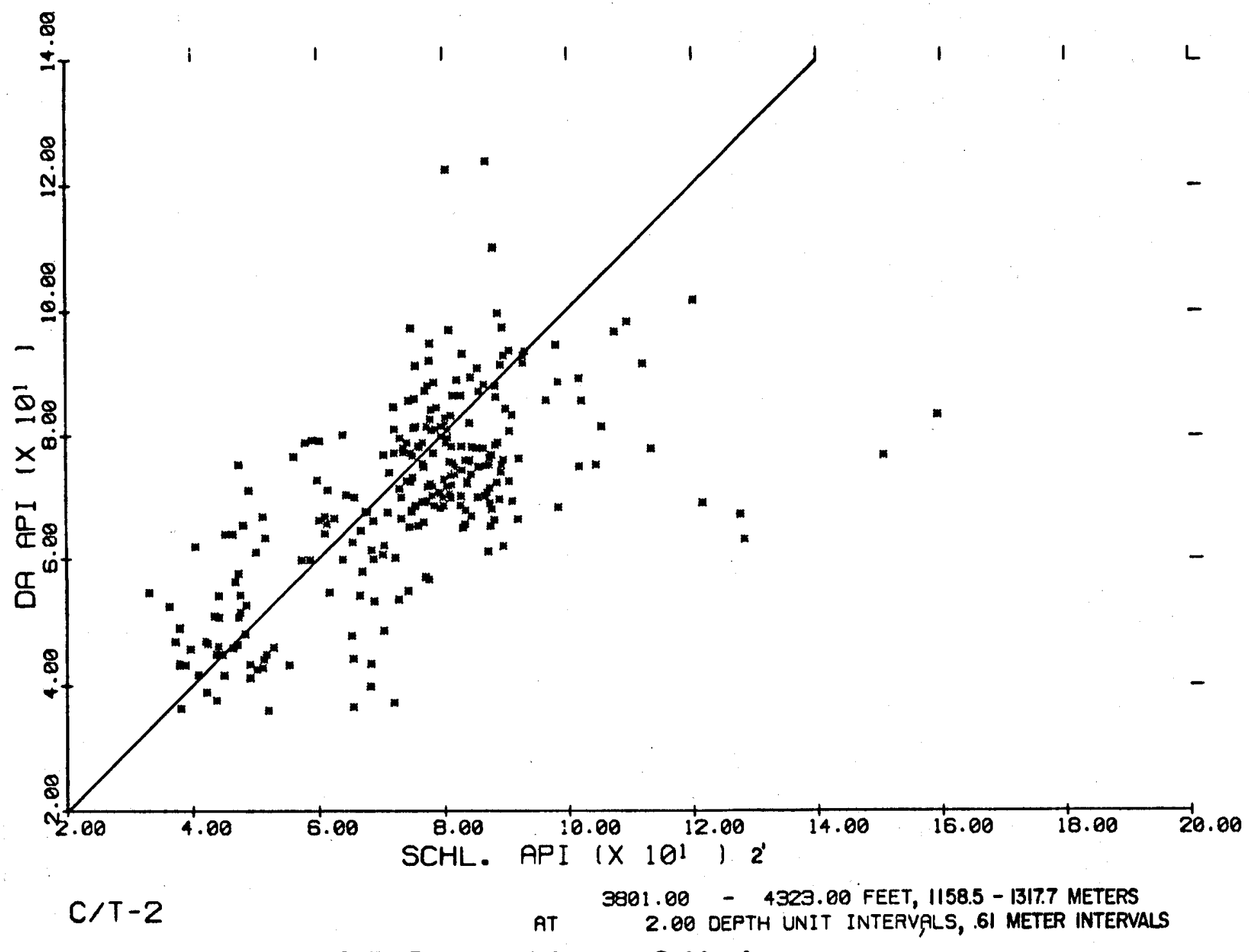

Fig. 6-5. Dresser-Atlas vs Schlumbergor gamma-ray. 


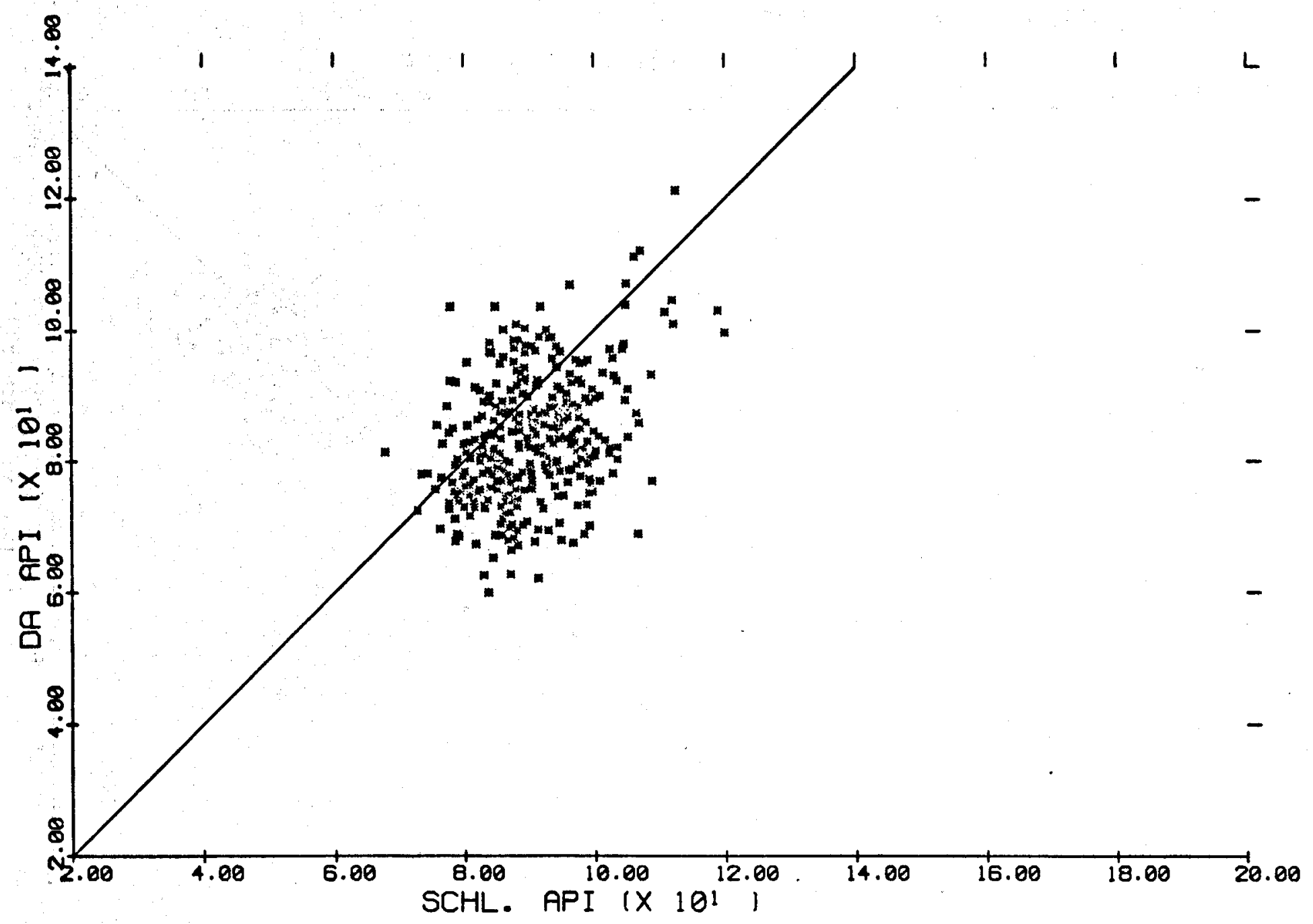
$\mathrm{C} / \mathrm{T}-2$

$5025.00-5723.00$ FEET, $1531.6-1744.3$ METERS 
స

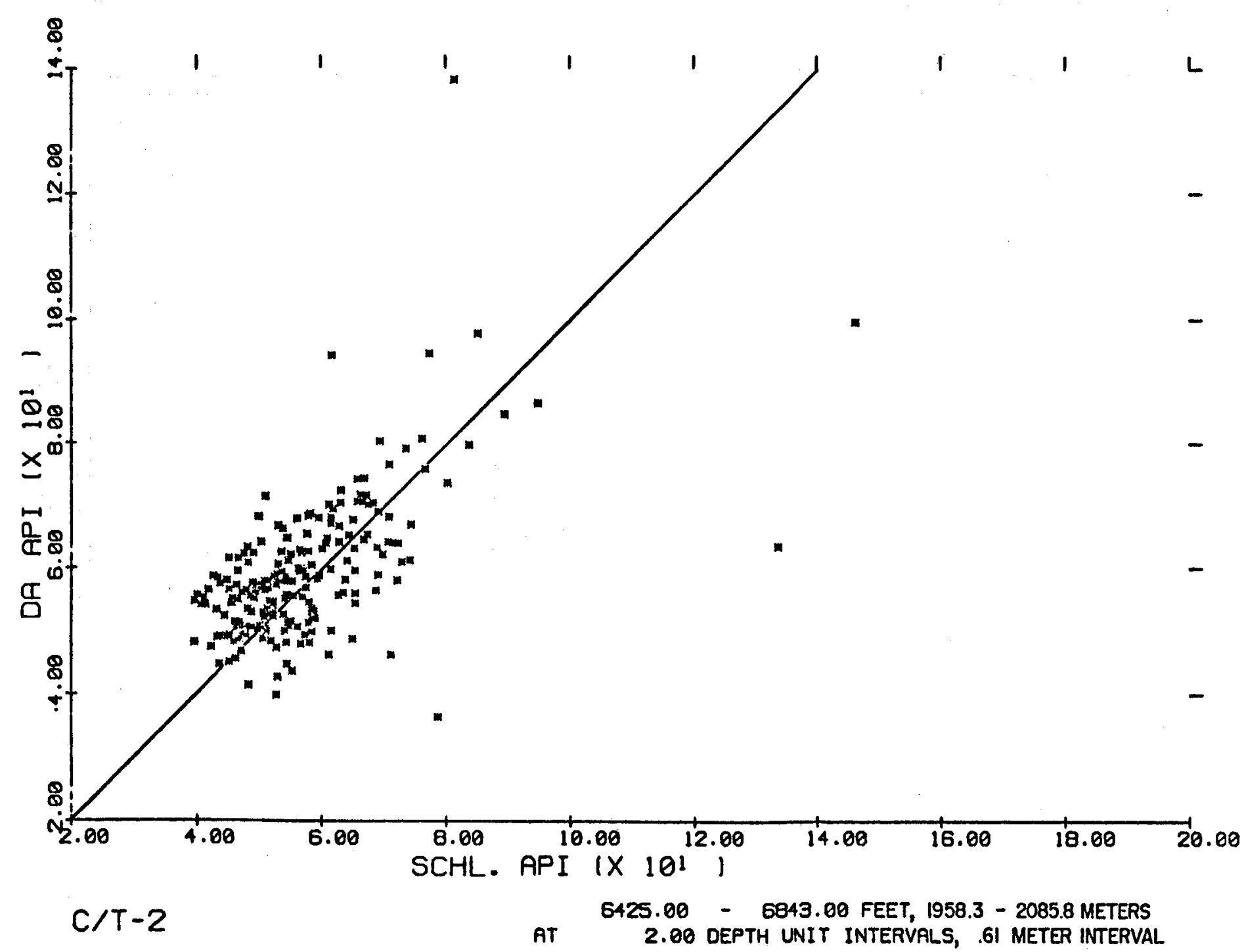

Flgure 6-7. Dresser-Atlas vs Schlumberger gamma ray. 
8. Summary Log Evaluations. The Dresser Atlas temperature and caliper logs exhibited characteristics attributed to tool malfunction. The temperature tool did fail shortly after reaching the bottom of the hole. The log contained several short intervals of near-zero temperature variation with depth and a number of discrete offsets attributed to tool sticking. Otherwise the log appears quite good and the bottom-hole temperature agrees with the previously reported value. The caliper log displayed both a decreasing (in casing) and an increasing (in the open hole) hole size with depth. One, but probably not both changes can be attributed to temperature affects. The decreasing hole size in casing suggests the tool was closing as it descended inside casing.

Thermal conductivity measurements obtained from chip samples could not explain all the variations seen in the temperature gradient curve computed from the temperature log. The gradient curve correlated in many instances to the neutron porosity log.

The Schlumberger acoustic logs appear reasonably good. Tool malfunctions did occur with some loss of data. A single receiver measurement was made which may mean the data are less accurate than would have been possible with a two-receiver measurement. One transmitter failed in the borehole and a second transmitter was used. The log recorded a later peak in the source wave over part of the borehole; therefore, velocities in this interval could not be computed. Although acoustic velocities are computed for the remainder of the borehole, they must be regarded as approximate.

The two neutron logs, both thermal neutron tools, were recorded in API units although the Dresser Atlas log was miscalibrated. The miscalibration was easily corrected. However, the Schlumberger log exhibited very little variability and the data were all well beyond the calibration curve, implying porosities close to zero throughout the open hole interval. Our guess is that the Schl. tool lost sensitivity in the high-temperature environment al though an error by the equipment operator cannot be excluded. Some difference in the two tool responses can be attributed to the different detectors used. The Schl. tool is sensitive to both thermal neutrons and gamma rays.

The Dresser Atlas density log was recorded in counts/min for both the long- and short-spaced detectors. The scales were labeled in reverse and the correction was trivial. As predicted by Dresser Atlas, the long-spaced 
measurement yielded the more reasonable density estimates. A significant discrepancy between the density $\log$ and the chip sample densities occurred in the lower portion of $\mathrm{C} / \mathrm{T}-2$. The differences can be attributed to one or more of the following: errors in the chip samples densities, larger than expected lower estimates of density in heavy mineral rocks by the density tool and an anomalous high porosity, up to $8 \%$, which cannot be supported by the neutron $\log$.

The electric $\log$ was Schlumberger's 6 FF40 induction $\log$ and an SP $\log$ was recorded simultaneously. The rock resistivities, as might be anticipated, were greater than 100 ohm-m and not particularly suited for logging by an induction device. The tool could not be centralized because of casing size above $1280.1 \mathrm{~m}(4200 \mathrm{ft})$. Therefore, the resistivity $\log$ yields probable minimum values and very little quantitative data. The SP log exhibited characteristic shale deflections opposite clay gouge and alteration mineral assemblages in fracture and fault zones. Several short sand-type deflections may indicate permeable fractures.

The Sch1. and Dresser Atlas gamma-ray logs were both recorded in API units and agree reasonably well. The logs showed common characteristics; acidic rocks generated higher gamma-ray counts than did the more mafic rocks. Fractures corresponded to anomalously high gamma-ray counts. Chip analyses indicated this response could be attributed to presence of uranium and thorium and/or their daughters.

A problem mentioned earlier, but addressed now, is the one of disagreement in recording of depth among the logs. Commoniy, logs can be aligned using a point of distinct response observed across a suite of logs. In C/T-2 several such features are available for comparing the logs. The most obvious feature is the bottom of casing which Phillips Petroleum Company reported to be at $1280 \mathrm{~m}(4200 \mathrm{ft})$. We have listed in Table 6-IV the casing point as seen on the various logs. Three points of distinct log response have also been picked on the various logs and listed in Table 6-IV. These points are the three fault or fracture intercepts at $1453.9 \mathrm{~m}(4770 \mathrm{ft}), 1767.8 \mathrm{~m}$ $(5800 \mathrm{ft})$ and $1920.2 \mathrm{~m}(6300 \mathrm{ft})$. The only accurate depths appear to be found on Schl. neutron, gamma-ray and velocity logs. All but the DA neutron seems to remain a fixed distance off throughout the hole. The DA neutron depth error appears to increase with depth from about $4.6 \mathrm{~m}(15 \mathrm{ft})$ near the top of 
TABLE 6-IV

COMPARISON OF DEPTHS TO VARIOUS DISTINCT FEATURES AS SEEN ON THE DIFFERENT LOGS. THE DATA ILLUSTRATE THE INCONSISTENT DEPTH RECORDING AMONG THE LOGS AND TO THE TRUE DEPTH OF THE FEATURES

\begin{tabular}{|c|c|c|c|c|}
\hline$\underline{\log }$ & Casing Depth & First Fault & Second Fault & Third Fault \\
\hline Reported Depth & $1280 \mathrm{~m}(4200 \mathrm{ft})$ & $1454 \mathrm{~m}(4770 \mathrm{ft})$ & $1768 m(5800 \mathrm{ft})$ & $1920 \mathrm{~m}(6300 \mathrm{ft})$ \\
\hline DA Caliper & $1292 \mathrm{~m}(4240 \mathrm{ft})$ & --- & --- & $-\cdots$ \\
\hline DA Velocity (CCL) & $1291 \mathrm{~m}(4237 \mathrm{ft})$ & $1443 \mathrm{~m}(4735 \mathrm{ft})$ & -- & --- \\
\hline Schl. Velocity & $1297 \mathrm{~m}(4255 \mathrm{ft})$ & $1452 \mathrm{~m}(4768 \mathrm{ft})$ & $\begin{array}{l}1768-1771 \mathrm{~m} \\
(5800-5810 \mathrm{ft})\end{array}$ & $\begin{array}{l}1914-1923 \mathrm{~m} \\
(6280-6310 \mathrm{ft})\end{array}$ \\
\hline DA Neutron & $1276 \mathrm{~m}(4185 \mathrm{ft})$ & $1446 \mathrm{~m}(4744 \mathrm{ft})$ & $1762 \mathrm{~m}(5780 \mathrm{ft})$ & $1913 \mathrm{~m}(6275 \mathrm{ft})$ \\
\hline Sch1. Neutron & $1281 \mathrm{~m}(4203 \mathrm{ft})$ & $1453 \mathrm{~m}(4766 \mathrm{ft})$ & $\begin{array}{l}1768-1771 \mathrm{~m} \\
(5799-5810 \mathrm{ft})\end{array}$ & $1920 \mathrm{~m}(6300 \mathrm{ft})$ \\
\hline DA Density & $1277 \mathrm{~m}(4190 \mathrm{ft})$ & $1448 \mathrm{~m}(4750 \mathrm{ft})$ & $1762 \mathrm{~m}(5780 \mathrm{ft})$ & $1917 \mathrm{~m}(6290 \mathrm{ft})$ \\
\hline Sch1. Induction/SP & $\cdots$ & $1452 \mathrm{~m}(4765 \mathrm{ft})$ & $1768 \mathrm{~m}(5800 \mathrm{ft})$ & --- \\
\hline Sch1. Gamma-Ray & $1281 \mathrm{~m}(4203 \mathrm{ft})$ & $1453 \mathrm{~m}(4766 \mathrm{ft})$ & --- & $\begin{array}{l}1919-1922 \mathrm{~m} \\
(6295-6304 \mathrm{ft})\end{array}$ \\
\hline DA Gamma-Ray & -- & --- & --- & $1914 \mathrm{~m}(6279 \mathrm{ft})$ \\
\hline
\end{tabular}


the hole to about $9.1 \mathrm{~m}$ (30 ft) at the bottom of the hole. In the next section, various data cross plots are studied and all logs were adjusted to common depths prior to making the cross plots.

\section{Cross Plots}

1. Basis for Plots. A common log interpretation technique utilized by log analysts in the oil and gas industry is the cross plot (Savre, 1963; Burke, et al., 1969; Poupon, et al., 1970; Pickett, 1973). Two or more sets of log data are plotted versus each other for the purpose of identifying distinct lithologies and estimating better porosity values. Very few logs, and often only in particular instances, respond to a single rock property. Hence one log may produce one set of data for two or more unknowns. To illustrate we will examine the commonly accepted response equations for the three so-called "porosity" tools: neutron, density and velocity tools.

The response equations are ( $\phi$ is porosity in each case)

$$
\text { neutron: } N D(\text { counts })=C+D \log \phi_{N}
$$

where $C$ and $D$ are empirical constants,

$$
\text { density } \rho_{b}=\rho_{g}\left(1-\phi_{D}\right)+\rho_{f} \phi_{D}
$$

where $\rho_{b}$ and $\rho_{g}$ are the bulk and grain densities, respectively and $\rho_{f}$ is the fluid density, and

$$
\text { velocity: } \Delta t=\Delta t_{m}+B \phi_{V}
$$

where $\Delta t$ and $\Delta t_{m}$ are the interval transit time from the log and the matrix travel time (assumed constant) and $B$ is an empirical constant.

The porosity in each case is given a subscript to indicate which log was used to compute it: $N$ for neutron, $D$ for density, and $V$ for velocity. The practice is to eliminate porosity from each pair of equations and a plot of the one $\log$ versus the other should yield values for the matrix constants $C$, $D, \rho_{g}$ and $\Delta t_{m^{*}}$ Note that any plot involving the neutron $\log$ will be a log-log plot unless the neutron $\log$ is in porosity units. In this instance Equation 6-5 simply reduces to $\phi_{N}$. The measurement of $\phi_{N}$ is dependent on lithology and neutron logs are commonly calibrated in limestone, sandstone and dolomite units.

These three equations are often expanded to describe several matrix components, each having a different response on the various logs (Edmundson and Raymer, 1979). The paper by Glenn and Hulen (1979) describes this 
expansion in the way most suitable to a study of igneous and metamorphic rocks. The neutron porosity is assumed to be composed of three parts, the pore porosity, $\phi_{p}$, the bound water "porosity", $\phi_{b}$; and an error term, $\phi_{e}$, due to any number of things including calibration error. The matrix density is assumed to be composed of lighter, nonhydrous minerals such as quartz and feldspars which constitute the bulk of most common igneous and metamorphic rocks, heavier, nonhydrous minerals, usually metallic minerals; and heavier hydrous minerals, usually the mafic minerals, the micas, the amphiboles and chlorite. Clays, if present, may be considered as either heavy or light hydrous minerals and are difficult to handle. The bound water in hydrous minerals is used to obtain a value for $\phi_{b}$. The contribution of the various matrix minerals to the velocity equation is more complex. The increased density of the mafic minerals may produce higher velocities but if present in significant amounts and if mostly platey minerals such as chlorite and the micas, the velocity may be reduced (Glenn and Hulen, 1979b).

In any case the previous equations can be rewritten as

$$
\phi_{N}=\phi_{p}+\phi_{b}+\phi_{e}
$$

where $\phi_{e}$ may be assumed to be zero, a constant or unknown and ignored,

$$
\rho_{b}=\rho_{s}\left(1-\phi_{D}-X\right)+\rho_{f} \phi_{D}+\rho_{m} X
$$

where $s$ is the density of the nonhydrous minerals and $m$ and $X$ are the density and volume fraction, respectively, of the hydrous mafic minerals.

$$
\Delta t=\Delta t_{s}(1-X)+\Delta t_{m} X+B \phi v
$$

where $\Delta t_{s}$ and $\Delta t_{m}$ are the travel times of the nonhydrous and hydrous mineral components in the matrix. The assumption that these components do not appreciably affect $B$ is somewhat tenuous.

To illustrate the cross-plot technique we will use a model presented by Glenn and Hulen (1979b) and we will use the neutron-density cross plot as an illustration.

Many of the hydrous mafic minerals in igneous and metamorphic rocks are denser than quartz and feldspar, which are commonly the predominant mineral constituent of the rock. Hence, these minerals should contribute to the response of both the neutron-porosity and bulk-density tools.

To illustrate, we will use two rock compositions shown in Table 6-V. 
TABLE 6-V

TWO ARBITRARY, GENERALIZED IGNEOUS/METAMORPHIC ROCK COMPOSITIONS

Minera1

Nonhydrous Silicates

Hydrous Mafic Minerals

Water (Porosity)
Rock 1

\begin{tabular}{lr}
\multicolumn{2}{c}{ Rock 1 } \\
\hline Density & $\mathrm{Vol}_{0} \%$ \\
(gm/cc) & $\mathrm{H}_{2} \mathrm{O}$ \\
\hline
\end{tabular}

2.60

3.15

1.00

\begin{tabular}{lr}
\multicolumn{2}{c}{ Rock 2 } \\
\hline Density & $\mathrm{Vol}^{2} \%$ \\
(gm/cc) & $\mathrm{H}_{2} \mathrm{O}$ \\
\hline
\end{tabular}

2.60

0.0

2.80

30.0

1.00

100.0

The grids shown in Figs. 6-8, 6-9, and 6-10 were constructed using these compositions and the $\log$ response equations. The grid lines with negative slopes are the usual porosity trends and each line represents a constant grain density and bound water content. The grid lines with a positive slope represent expected trends produced by varying hydrous mineral content at a constant porosity. If both porosity and hydrous mineral variations occur simultaneously, the data may plot in a very scattered fashion, a common experience. Figures 6-8 and 6-9 illustrate the effect of changing both the density and bound water content of the hydrous mafic minerals. Figure 6-10 is an expanded version of Figure 6-8 and depicts the typical density and neutron porosity ranges that occur in igneous and metamorphic rocks. Figure 6-10 illustrates the determination of true porosity, true grain density and per cent hydrous mineral for some arbitrary data point $P$. Note that one does not extrapolate to zero porosity and the bulk density axis at zero neutron porosity to obtain the grain density, but to the zero mafic minerals line.

The plots shown in Figs. 6-8, 6-9 and 6-10 ignore any calibration effects or nonlinear effects known to exist at low porosities. Most logs are recorded using limestone or sandstone calibrations. No calibrations exist for any of the variety of igneous and metamorphic rocks encountered in C/T-2 but the authors' experience suggests that most of these rocks would exhibit data trends that would fall between the limestone and sandstone calibration lines. Matrix effects are often present in the neutron response and, for example, sandstone porosity using a limestone calibration, begins at $-1.5 \%$ porosity for Schlumberger's compensated neutron log. Nonlinear effects are also evident, particularly at low porosities. Glenn and Hulen (1979b) showed empirically 


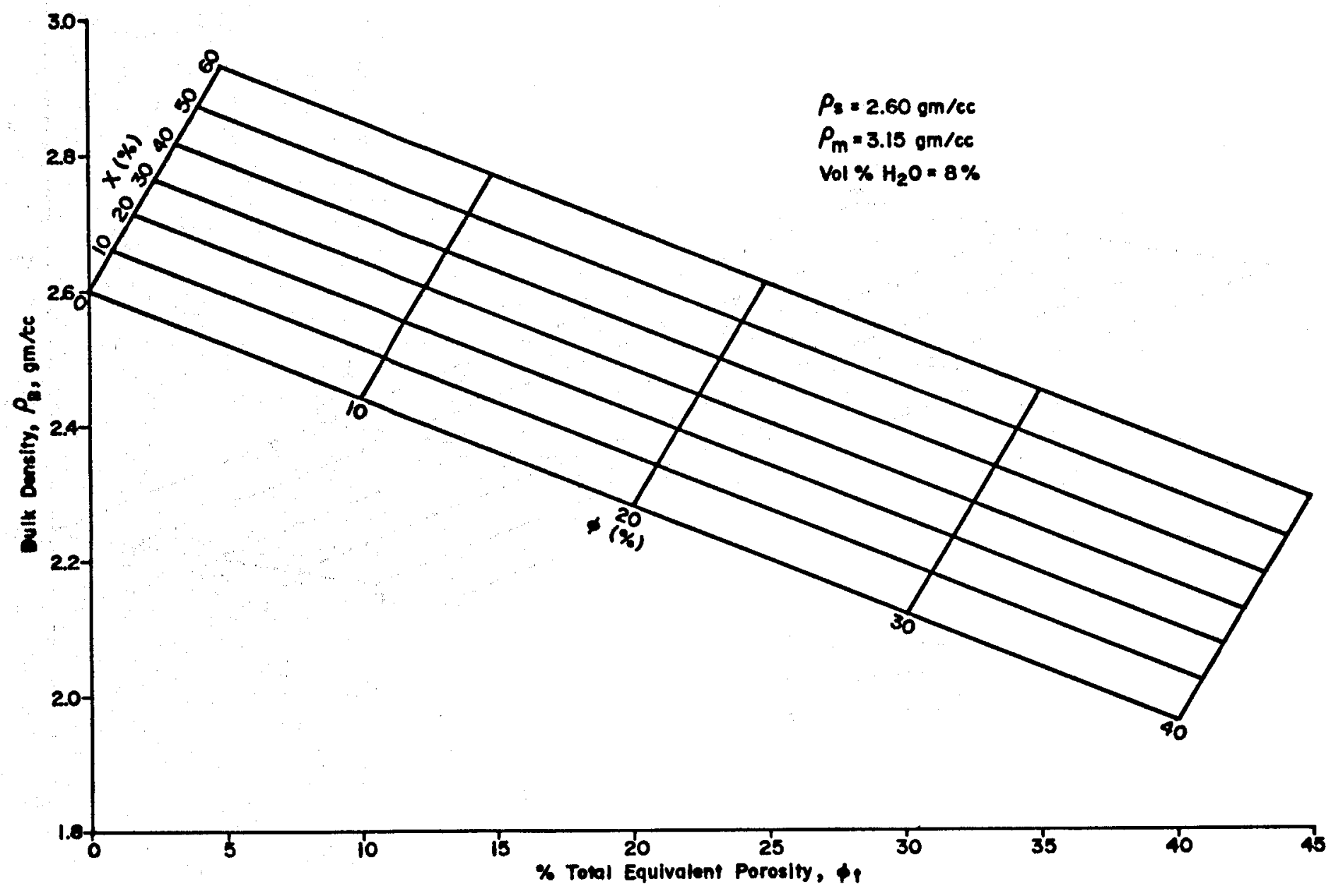

Fig. 6-8. Density ve moutron poroelty crose plot grld for "rock 1" composition in Table 6-IV. 
$\ddot{\omega}$

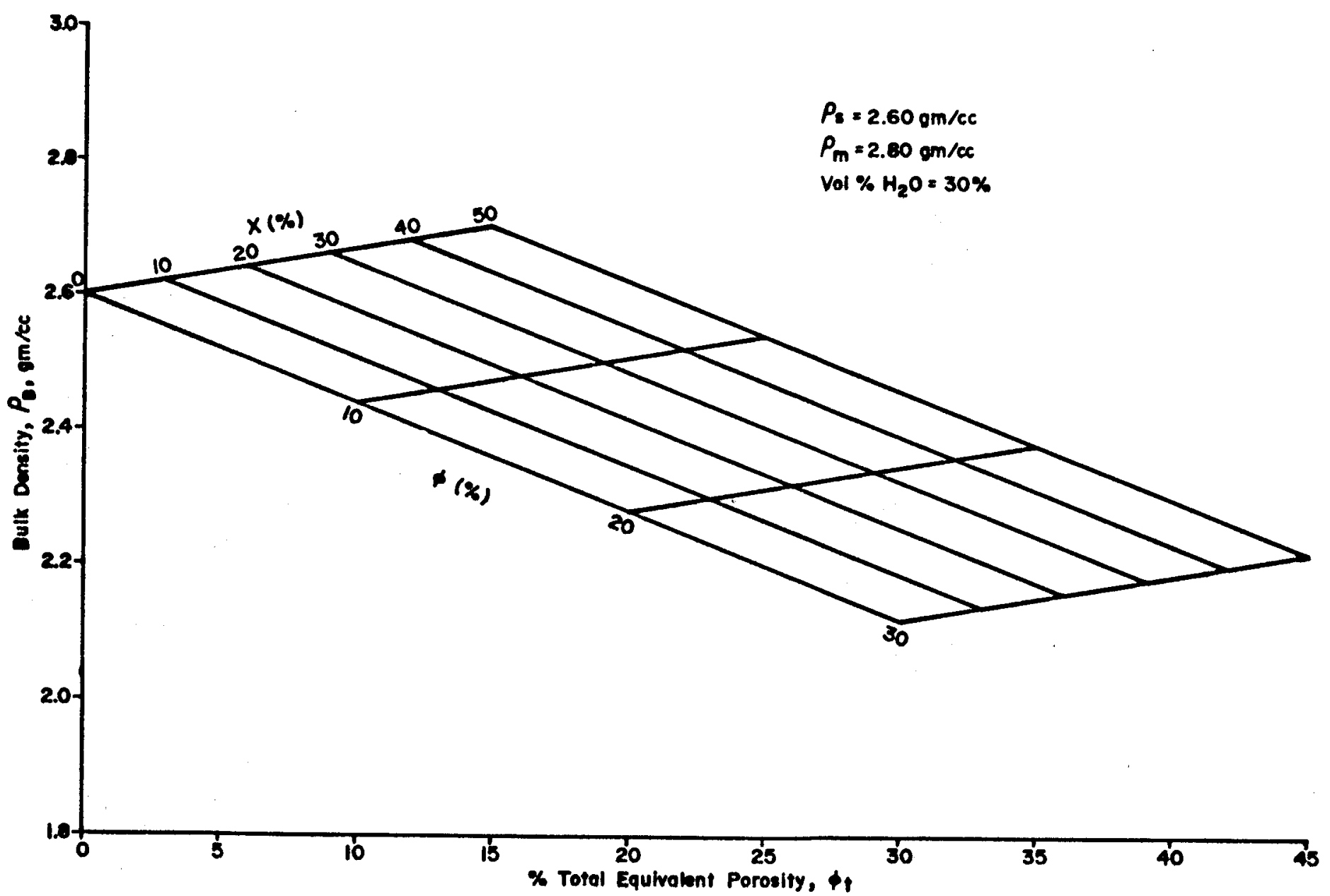

Fig. 6-9. Density va neutron porosity cross plot grid for "rock 2" composition in Table 6-1V. 


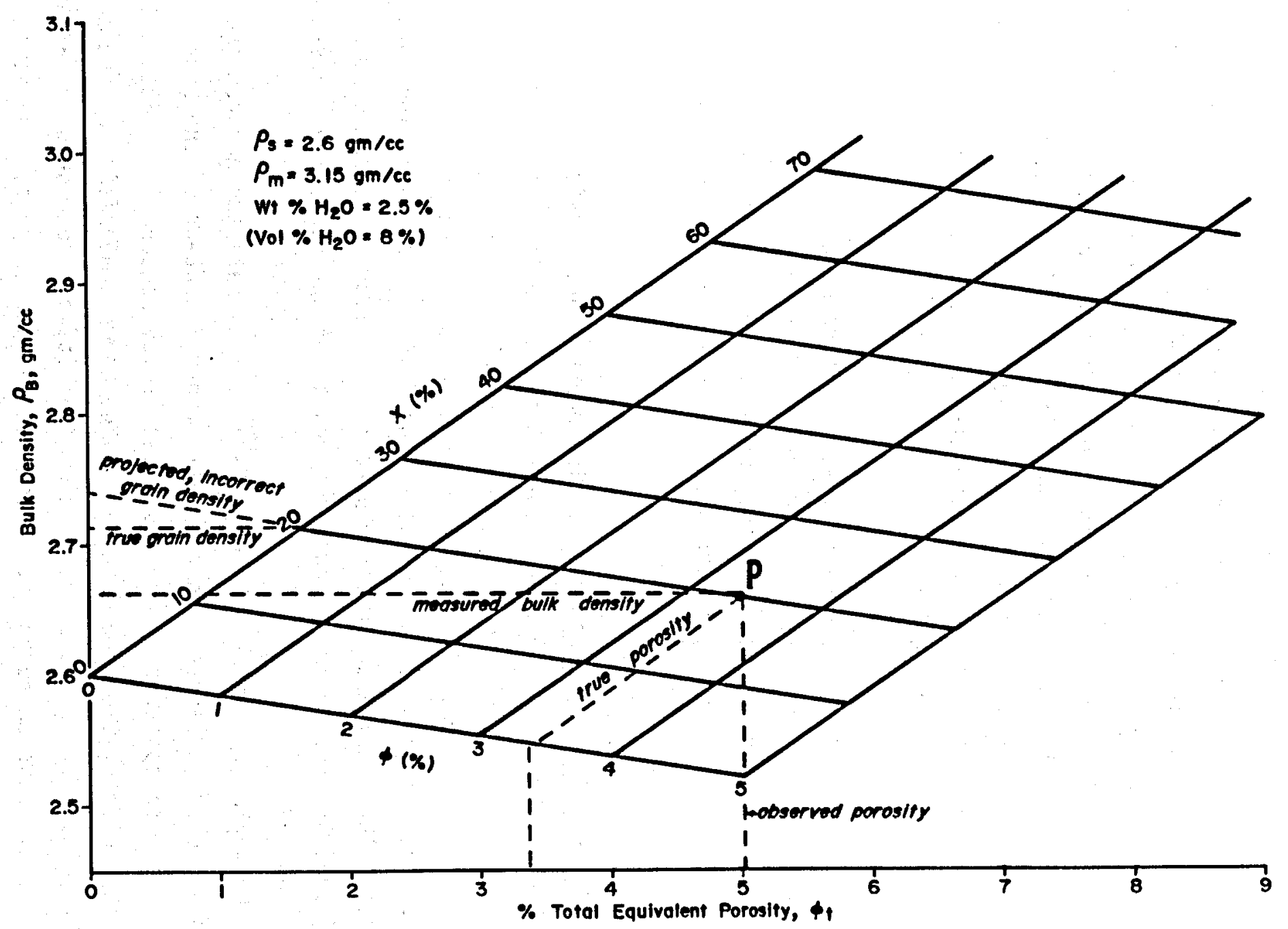

Fig. 6-10. Expanded scale version of fig. 6-8 (includes a demonstrated use of grid). 
that matrix porosity for the Schlumberger CNL tool in Roosevelt Hot Springs rocks is -1 to $-2 \%$. Edmundson and Raymer (1979) have calculated -1 to $-2 \%$ porosity for feldspars using the Schlumberger neutron tools and a limestone calibration. The DA neutron tools' zeros may be -2 to $-4 \%$ (Dresser Atlas, 1979). Therefore, the porosity zero for C/T-2 rocks should be at least -1 to $-2 \%$ using a limestone calibration and approximately zero using a sandstone calibration. A limestone calibration curve was used to convert the DA neutron log data to porosity data. The densities of many heavy minerals may be underestimated 0.01 to $0.03 \mathrm{~g} / \mathrm{im}^{3}$ by a density tool. A few minerals have errors outside this range or possibly an over-estimate of density. These errors are not examined here. These minerals may also alter the neutron response significantly from calibration due to effect on rock capture cross section.

Data analyses, primarily cross plots, have been made for selected open hole intervals. The intervals have been selected as representative of different log response characteristics. Only two rock types occur in the open hole interval of $\mathrm{C} / \mathrm{T}-2$ and it is not possible to study all the lithologies intersected by the drill hole.

2. Neutron-Density Cross Plots. The neutron and density logs were shifted downhole by $9.2 \mathrm{~m}(30 \mathrm{ft})$ to correct for the depth offset problem noted earlier. Three depth intervals are cross plotted in Figs. 6-11, 6-12 and 6-13 and the intervals include the ones where chip samples were analyzed in detail. The values used to compute the grid in each case are included in the figures. The density and neutron porosity of water are assumed to be 1 $\mathrm{gm} / \mathrm{cc}$ and $100 \%$ and the apparent neutron porosity of the nonhydrous minerals is assumed to be $-2 \%$.

All three plots, particularly Fig. 6-12, demonstrate the neutron and density measurement dependence on the mafic mineral content of the rock. The parameters used to construct the grids appear to be reasonable choices both in terms of the grids' fit of the data and of the known composition of the rock. The data in Fig. 6-11 follow a trend which exhibits a strong density variation and a very small neutron response. This trend arises in part, because the data interval crosses the quartz monzonite and granodiorite contact. The intervals plotted in Fig. 6-12 and 6-13 are entirely within the granodiorite. 


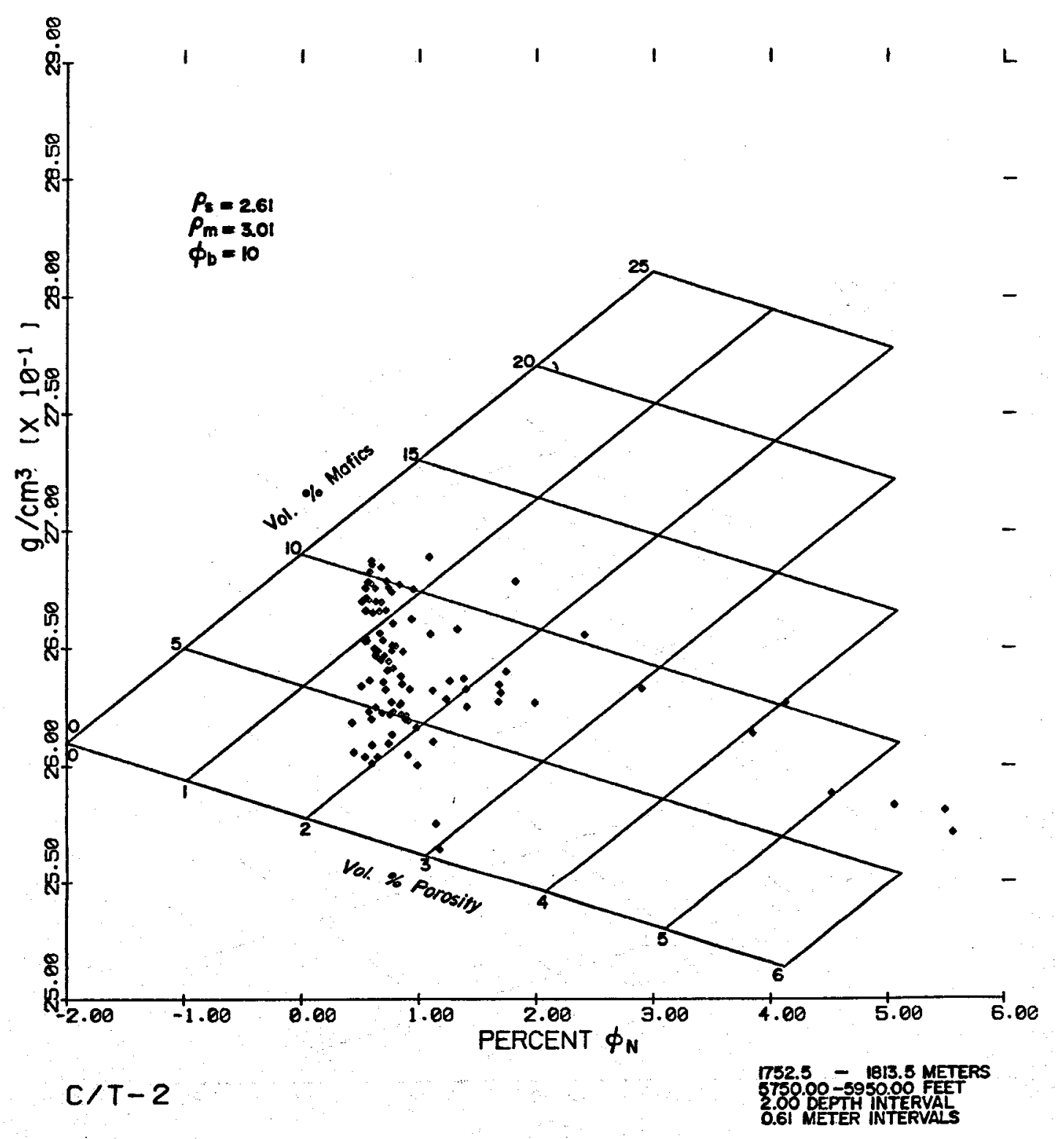

Fig. 6-11. Bulk density ys neutron porosity . 


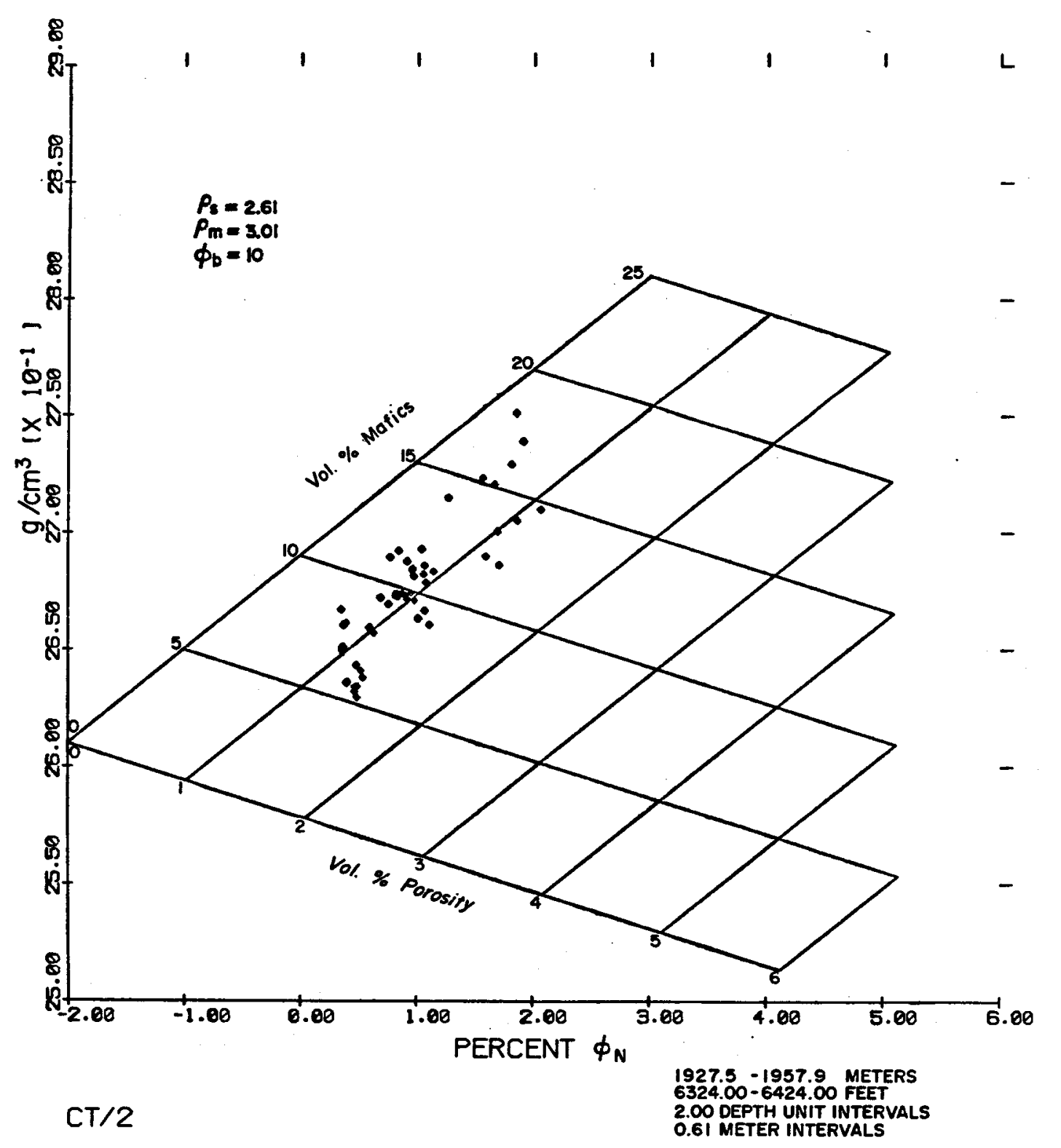

Fig. 6-12 Bulk density vs neutron porosity . 


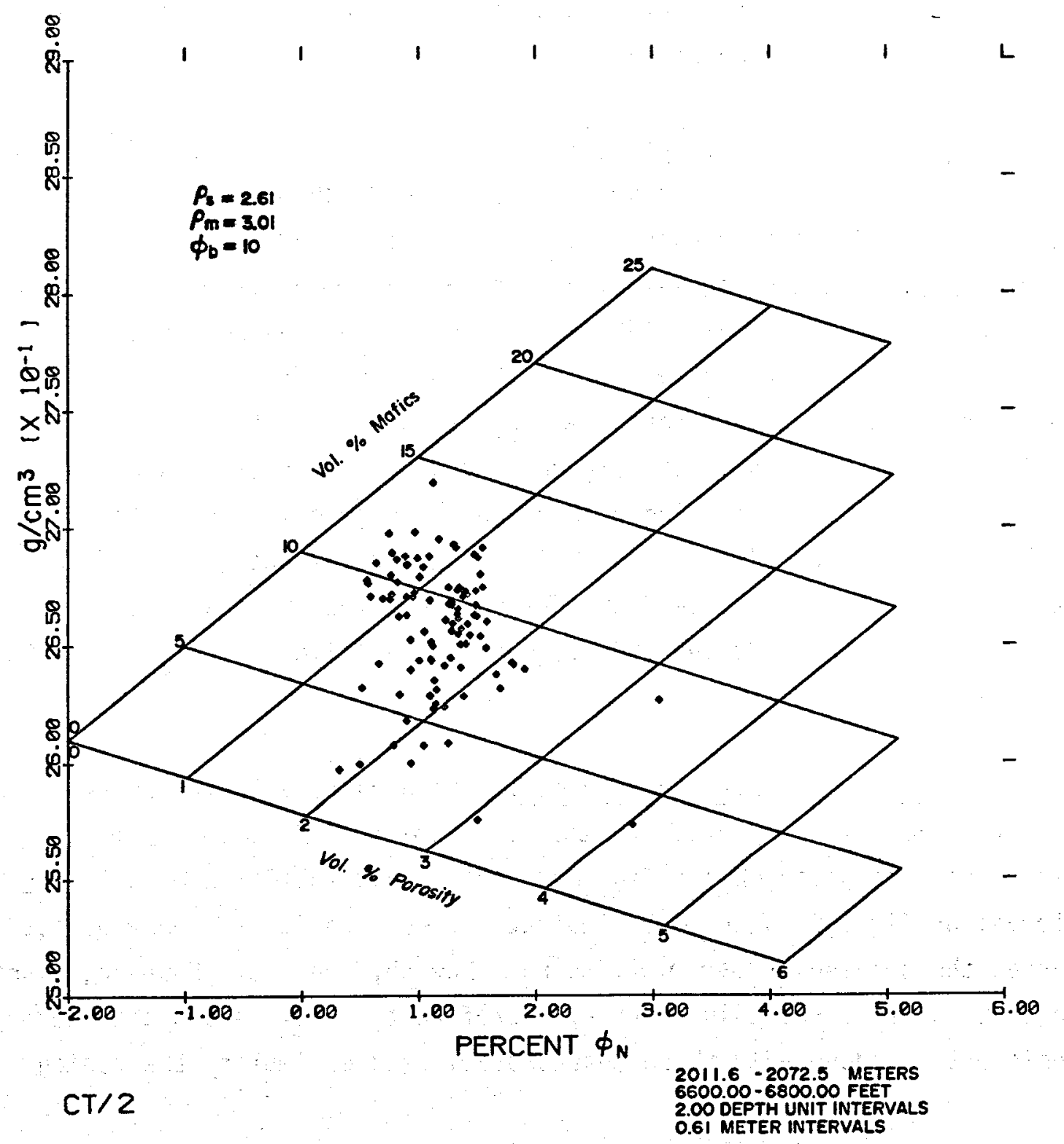

Fig. 6-13. Bulk density vs neutron porosity . 
The log interpretations verify the analyses shown in Table 2-I and the differentiation of two distinct rock units. The granodiorite contains 5 to $10 \%$ more mafic minerals than the quartz monzonite. The data in Table 2-I suggest a slightly higher mafic mineral content than do the log data. We have stated earlier that the chips may have been depleted in quartz and feldspar minerals due to the very fine-grained state of the chip samples. The log data tend to support this conclusion.

3. Neutron-Velocity Cross Plots. The velocity log was not shifted in depth as it was determined to be close to true depth. The neutron and density $\log$ shifts noted above brought these two logs into alignment with the velocity log. The neutron velocity cross plots are shown in Figs. 6-14 and 6-15 for the upper and lower intervals used for the neutron density cross plots. The 1927.5 to $1972.7 \mathrm{~m}$ (6324 to $6470.5 \mathrm{ft}$ ) interval is not plotted since the velocity data are largely invalid in this interval. Grid overlays are also shown in the figures and were constructed using the values indicated in the figures. The points above the grid in Fig. 6-14 correspond to the fault zone at $1767.8 \mathrm{~m}(5800 \mathrm{ft})$. In general the grids are consistent with those in Figs. 6-11, 6-12 and 6-13. The velocity data in the interval 2012.0 to $2072.3 \mathrm{~m}(6600$ to $6800 \mathrm{ft})$ may not be valid since $E_{3}$ rather than $E_{1}$ may have been recorded.

4. Density-Velocity Cross Plots. The density-velocity cross plots are shown on Figs. 6-16 and 6-17 for the two intervals discussed above. Again the grid values are given on the figures. The 1752.9 to $1813.2 \mathrm{~m}$ (570 to $5950 \mathrm{ft}$ ) interval on Figs. 6-16 and 6-17 indicates zero porosity for many points whereas the previous cross plotsdid not show this result. However, a shift in one plot causes a shift in another; therefore the plots shown are the most consistent. Undoubtedly these interpretations oversimplify the geology.

5. $M N, A K$ and $Z$ Plots. $M N$ and $Z$ plots are special data cross plots advocated by Schlumberger $(1972,1974)$ and the former is a registered trademark of that company. Dresser Atlas (1979) proposes the use of the MN plot and the AK plot which has similar properties to the MN plot. 


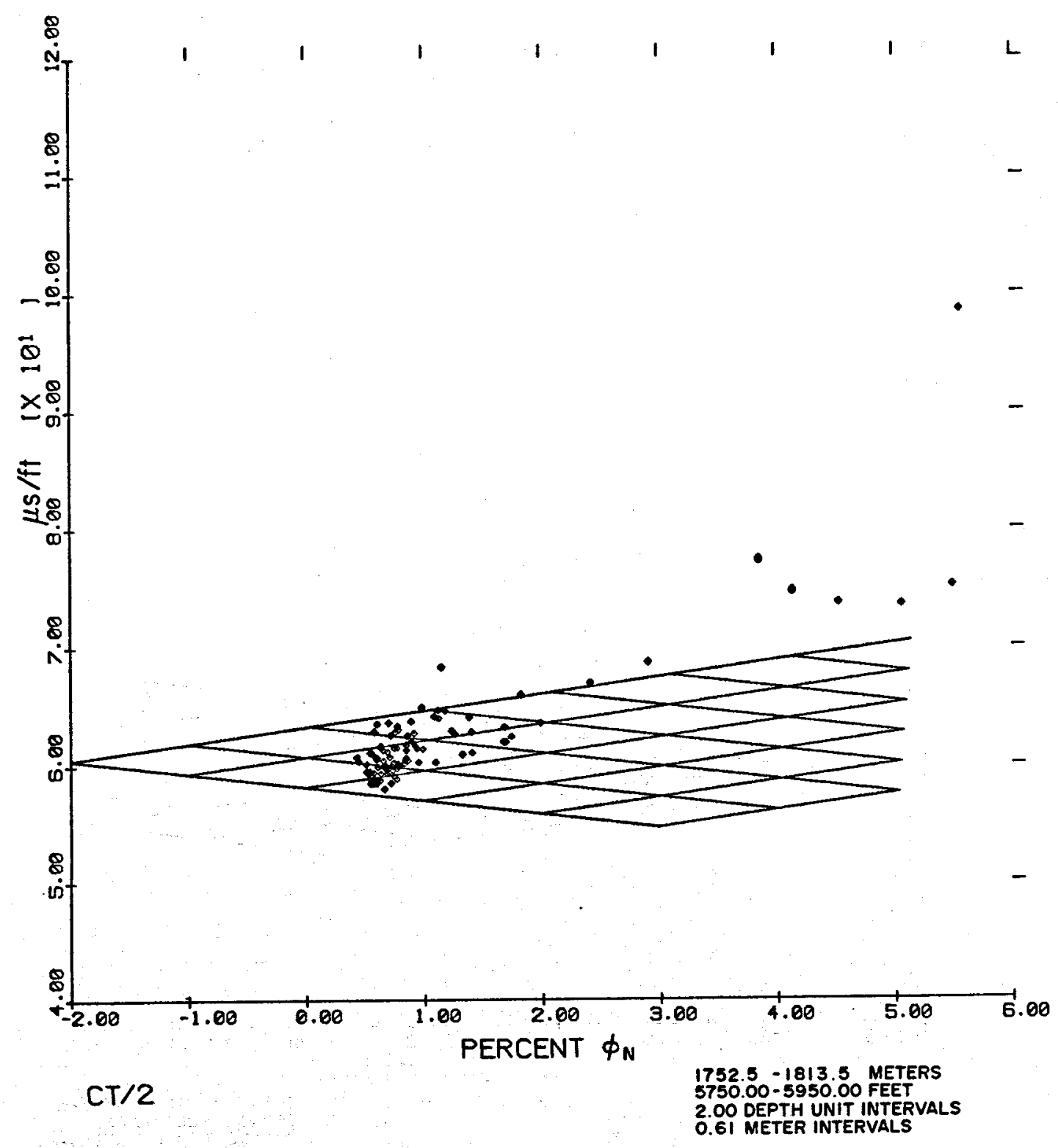

Fig. 6-14. interval transit time ve neutron porosity. 


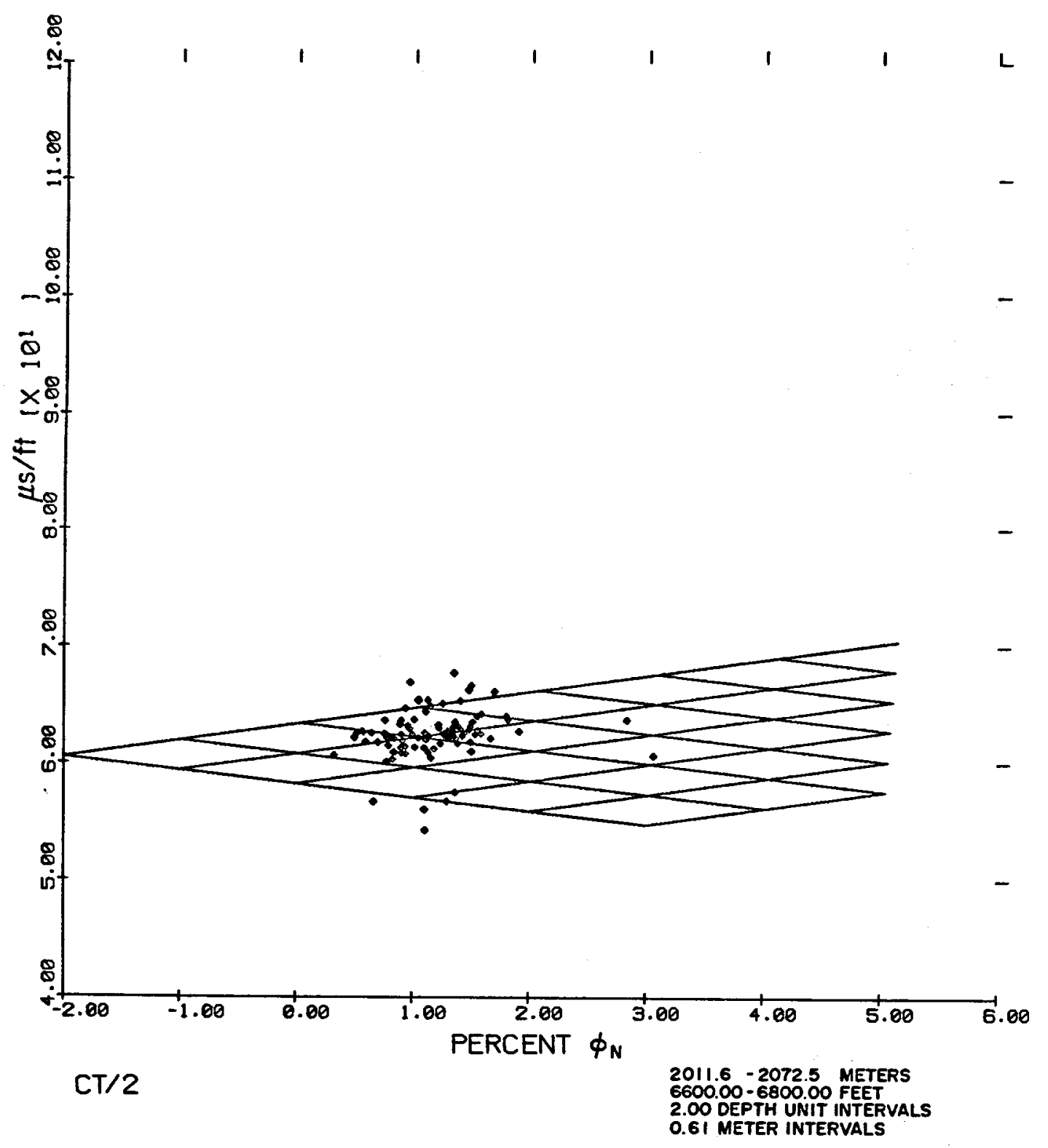

Fig. 6-15. Interval transit time ve neutron porosity. 


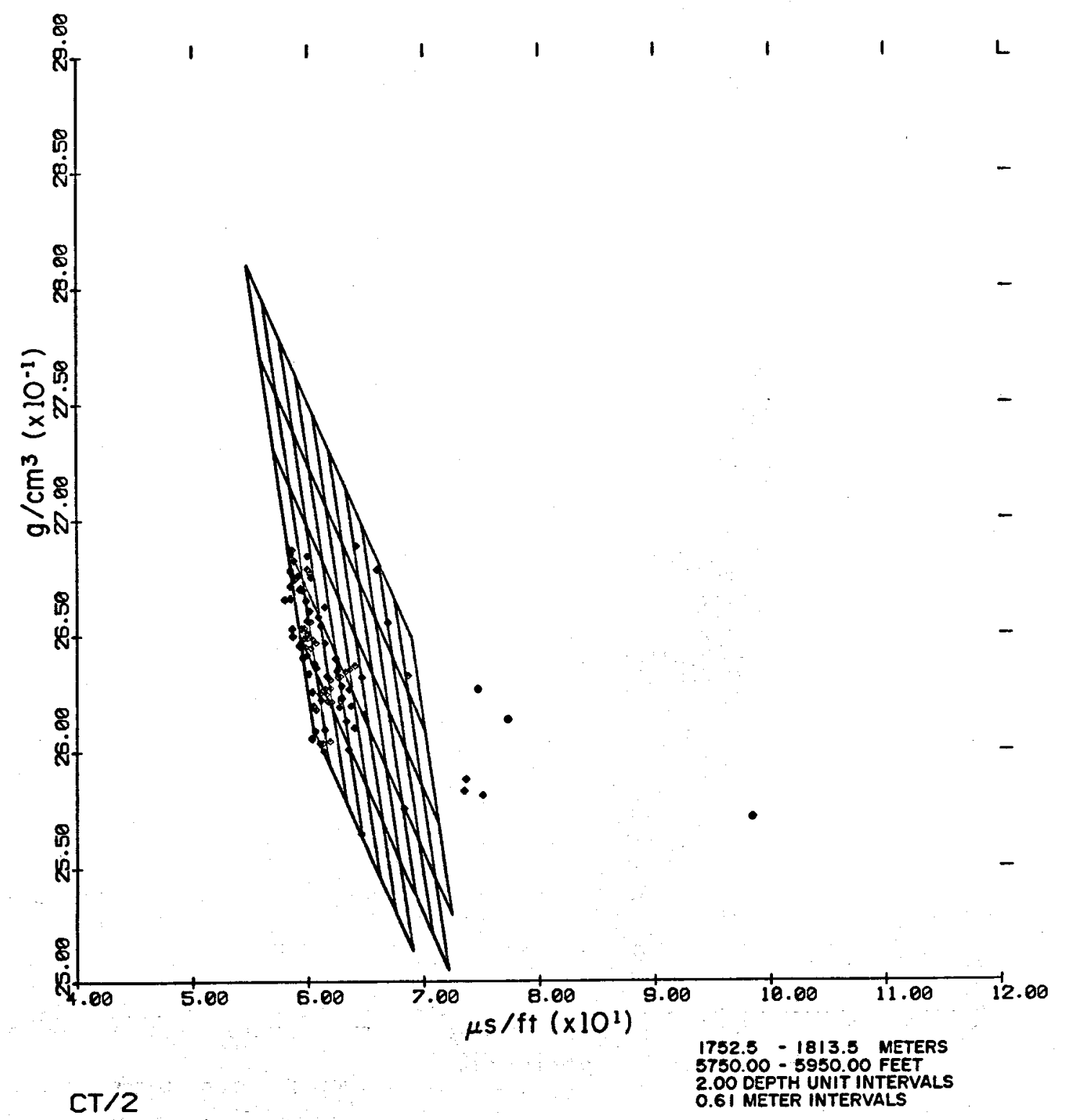

Fig. 6-16. Bulk density ve Interval transit time. 


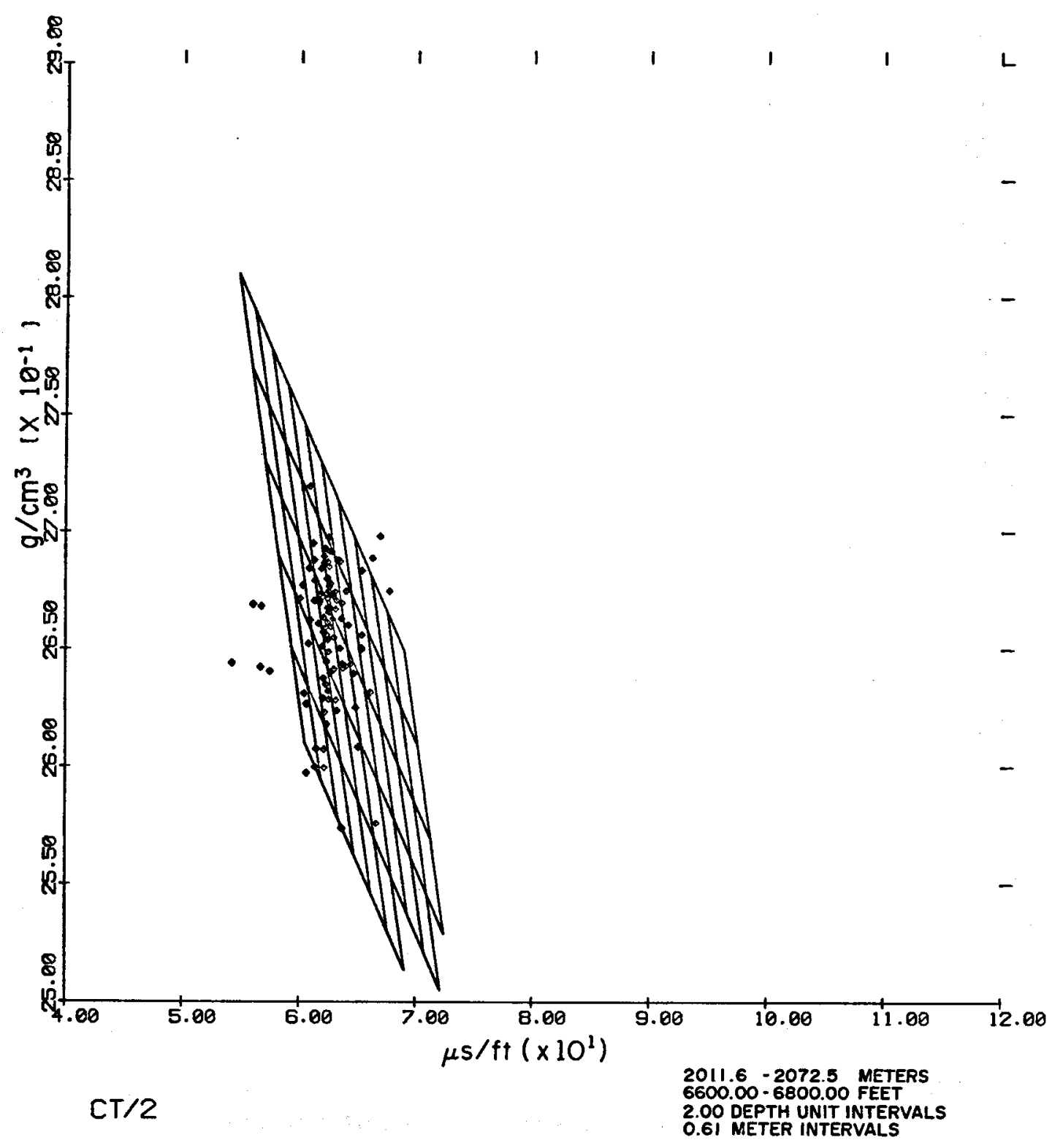

Fig. 6-17. Bulk density vs interval translt time. 
The MN and AK plots are constructed from the neutron, density and velocity log data as follows:

$$
\begin{aligned}
& M=\frac{\Delta t_{f}-\Delta t}{\rho_{b}-\rho_{f}} \quad \times 0.01, \\
& N=\frac{\phi_{N f}-\phi_{N}}{\rho_{b}-\rho_{f}},
\end{aligned}
$$

and

$$
\begin{aligned}
& A=\frac{\rho_{b}-\rho_{f}}{1-\phi_{N}}, \\
& K=0.01 \times \frac{\Delta t_{f}-\Delta t}{\phi_{N f}-\phi_{N}} .
\end{aligned}
$$

These equations are developed from the basic log response equations whereby primary porosity has been eliminated. Hence these quantities are viewed to be primarily lithology dependent. Particular rock types have characteristic pairs of MN and AK values. We did not plot either the MN or AK plots.

The Z-plot is simply a presentation which incorporates a third set of log data into a standard cross plot. The third set of log data is plotted as a scaled value at the corresponding plot point of the other two log values. A common $\log$ plotted as the $Z$ variable is the gamma-ray log, for example, see Table 7.1 p. 80 in Schlumberger, 1974. Another common plots use travel time or caliper as the $Z$ variable.

The Z-plots, using the DA gamma-ray $\log$ for $Z$ and the neutron and density cross plot for the intervals discussed above, are shown in Figs. 6-18, 6-19 and 6-20. Only the interval 1753 to $1813 \mathrm{~m}$ ( 5751 to $5949 \mathrm{ft}$ ) exhibits any particular pattern. Highest neutron porosities correlate with gamma-ray counts between 100 and 120 API units and represented by a 4 in Fig. 6-18. These data probably indicate the presence of clay minerals which contain both potassium and bound water. Clay minerals also have a range in densities consistent with the wide distribution of points indicated in Fig. 6-18. 


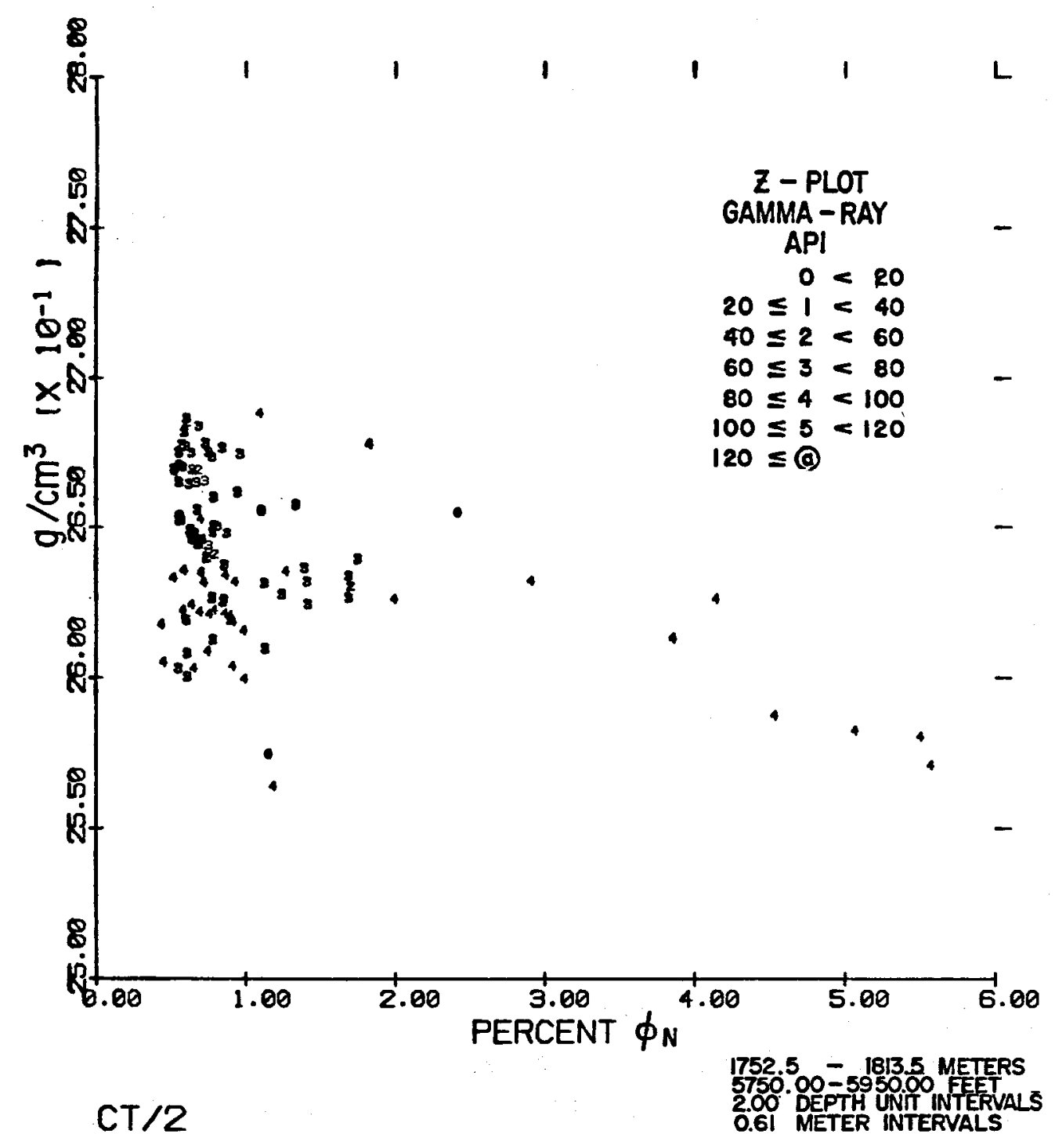

Fig. 6-18. Bulk density vs neutron porosity. 


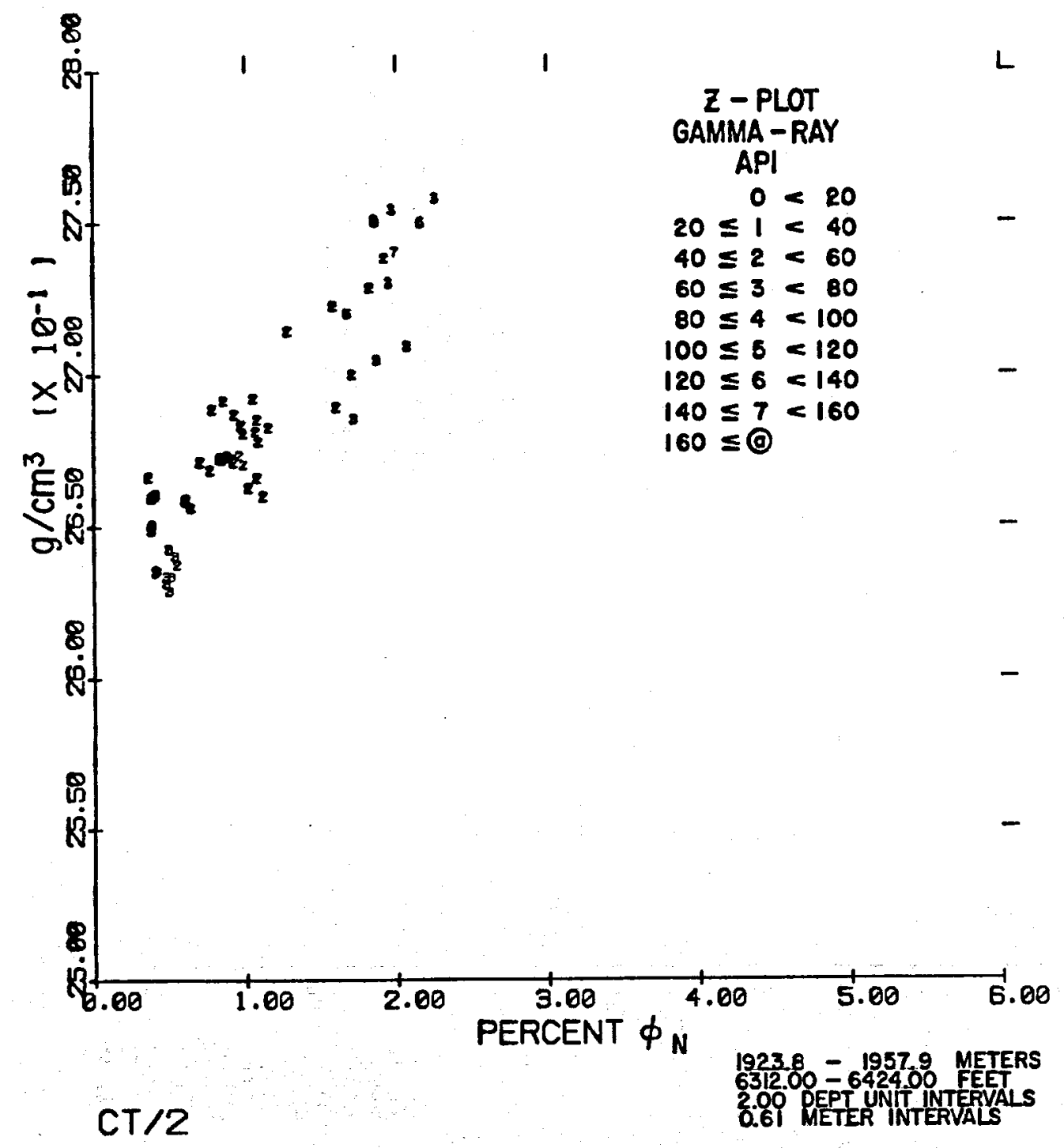

Fig. 6-19. Bulk Density vs Neutron Porosity. 


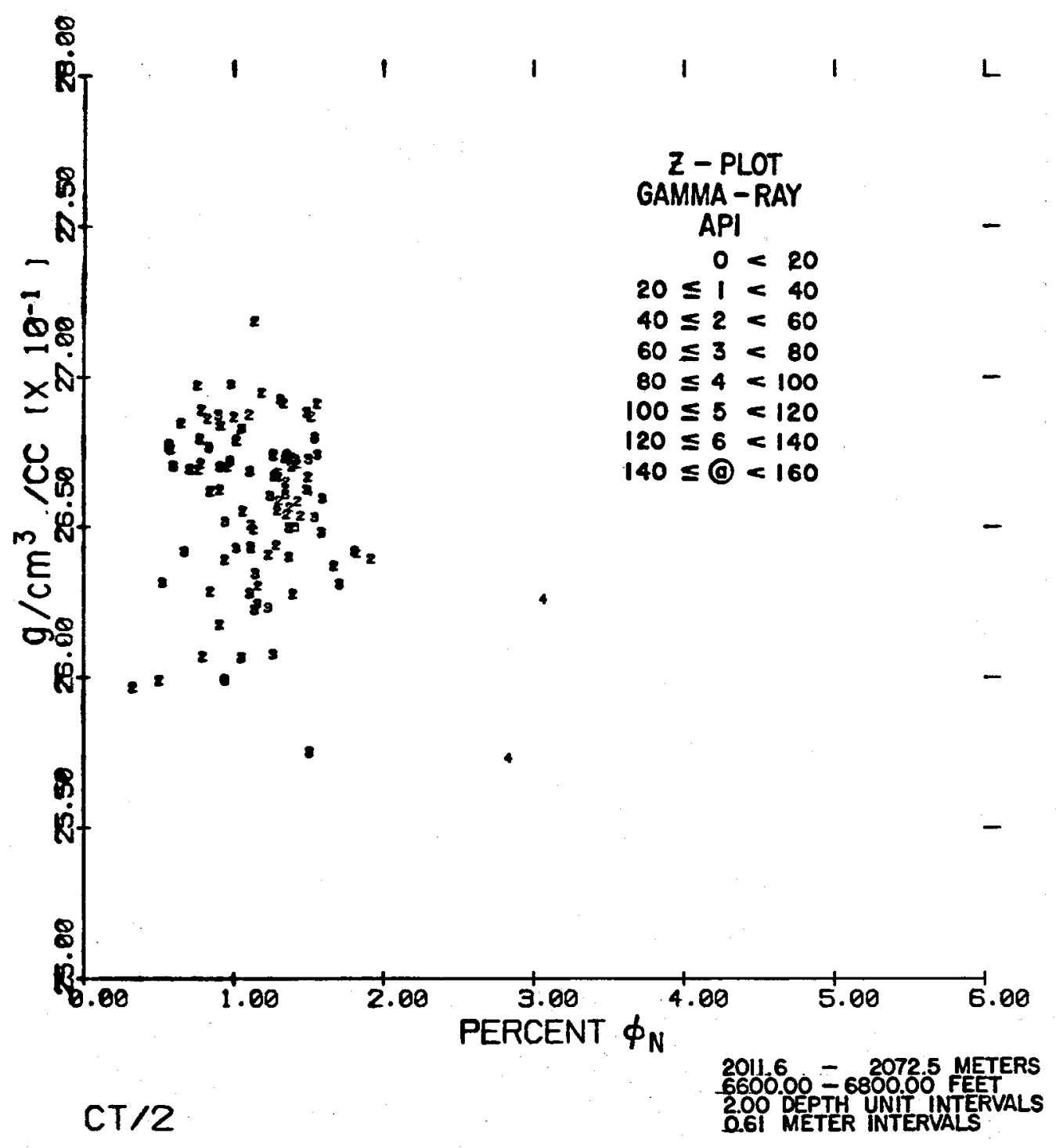

Fig. 6-20. Bulk density ve, neutron porosity. 
The neutron porosity density cross plotswith interval travel time as the $Z$ variable are plotted in Figs. 6-21 and 6-22. The intermediate depth interval is not plotted since the velocity data are largely invalid. Only the upper interval, Fig. 6-21, exhibits distinct data correlations. The I's are associated with higher density and both lower neutron porosity and lower travel time. These data define the lowest porosity, most mafic rock, the granodiorite. The 2's, although less definitive, correlate largely with the low porosity, less mafic quartz monzonite. Other 2's and all 3's and greater correspond to increased porosity and/or clay gouge in the quartz monzonite.

6. Gamma-Ray Cross Plots. The DA gamma-ray data have been plotted versus density and neutron data for all three intervals and acoustic data for the upper and lower intervals, and the plots are shown in Figs. 6-23, 6-24 and $6-25$.

In the 1752.5-1813.5 $\mathrm{m}(5750-5950 \mathrm{ft})$ interval the gamma-ray and bulk density data appear to be better correlated than the neutron and gamma-ray data (Figs. 6.23a and 6.23b). The only neutron and gamma-ray correlation is the one at higher neutron porosities previously noted on the Z-plot (Fig. 6-20). Remember that this interval crosses the quartz monzonite and granodiorite contact. The higher gamna-ray and lower density values reflect the greater amount of potassium feldspar and lower amount of heavier mafics in the quartz monzonite.

In the 1923.8-1957.9 $\mathrm{m}$ (6312-6424 ft) interval the gamma-ray data are highly correlated to both bulk density and neutron porosity data. Increasing gamma-ray counts (API units) correspond to lower neutron porosity and lower bulk density. This result is consistent with the conclusions made for the $1752.5-1813.5 \mathrm{~m}(5750-5950 \mathrm{ft}$ ) interval. The potassium variation (gamma-ray $10 \mathrm{~g})$ is due primarily to potassium feldspar variations. Potassium feldspar has a density between 2.55 and $2.62 \mathrm{~g} / \mathrm{cm}^{3}$ and is nonhydrous. The higher neutron porosity, higher density and lower gamma ray reflect the decreasing $\mathrm{K}$-feldspar content and increasing amounts of hydrous, lower potassium minerals, the mafic minerals.

The third interval, 2011.6-2072.5 m (6600-6800 ft), exhibits similar, although less compact, trends to the above interval. The relationships are those al ready described. 


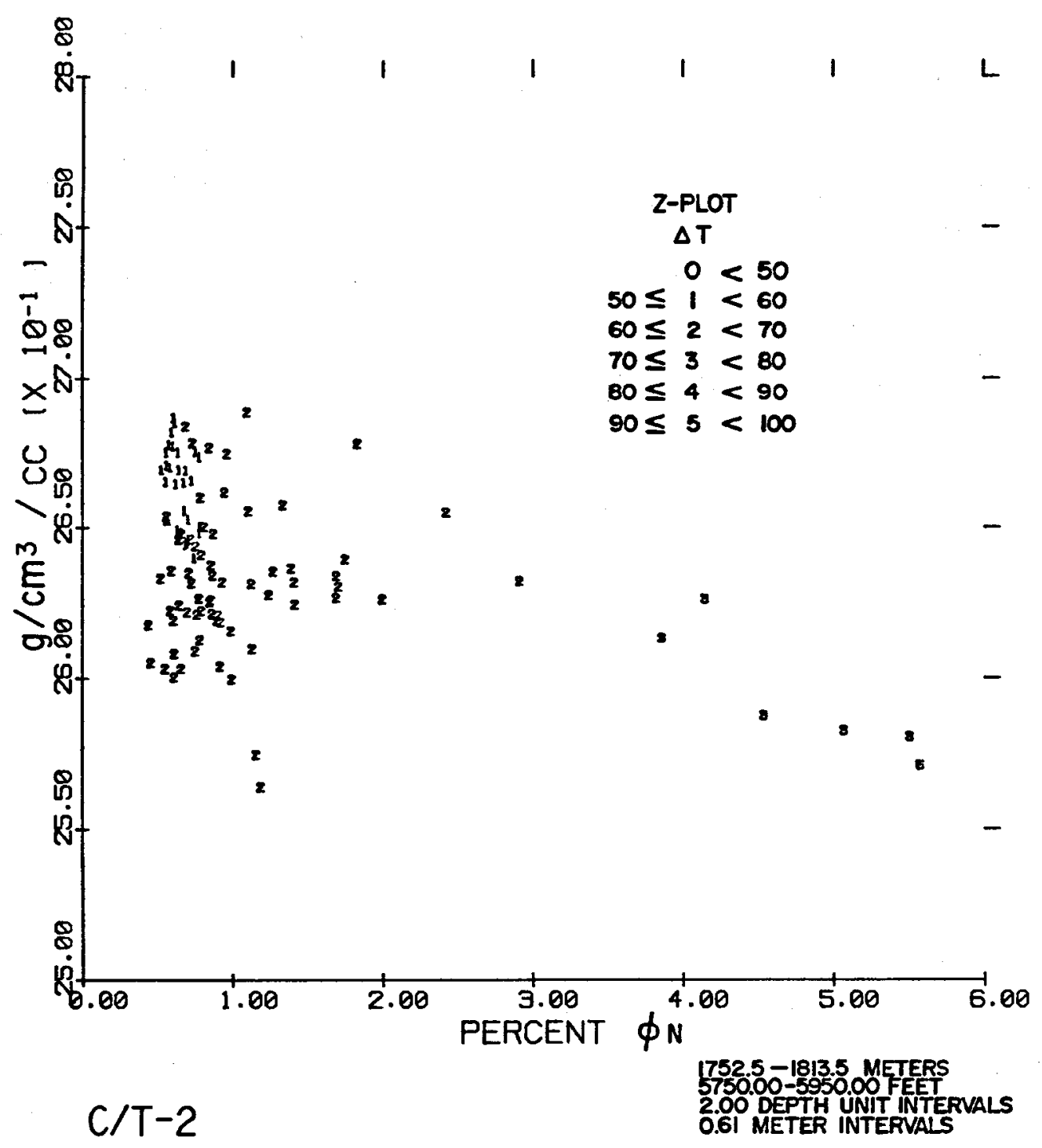

Fig. 6-21. Z-Plot, bulk density vs neutron porosity with gamma ray in $Z$ direction. 


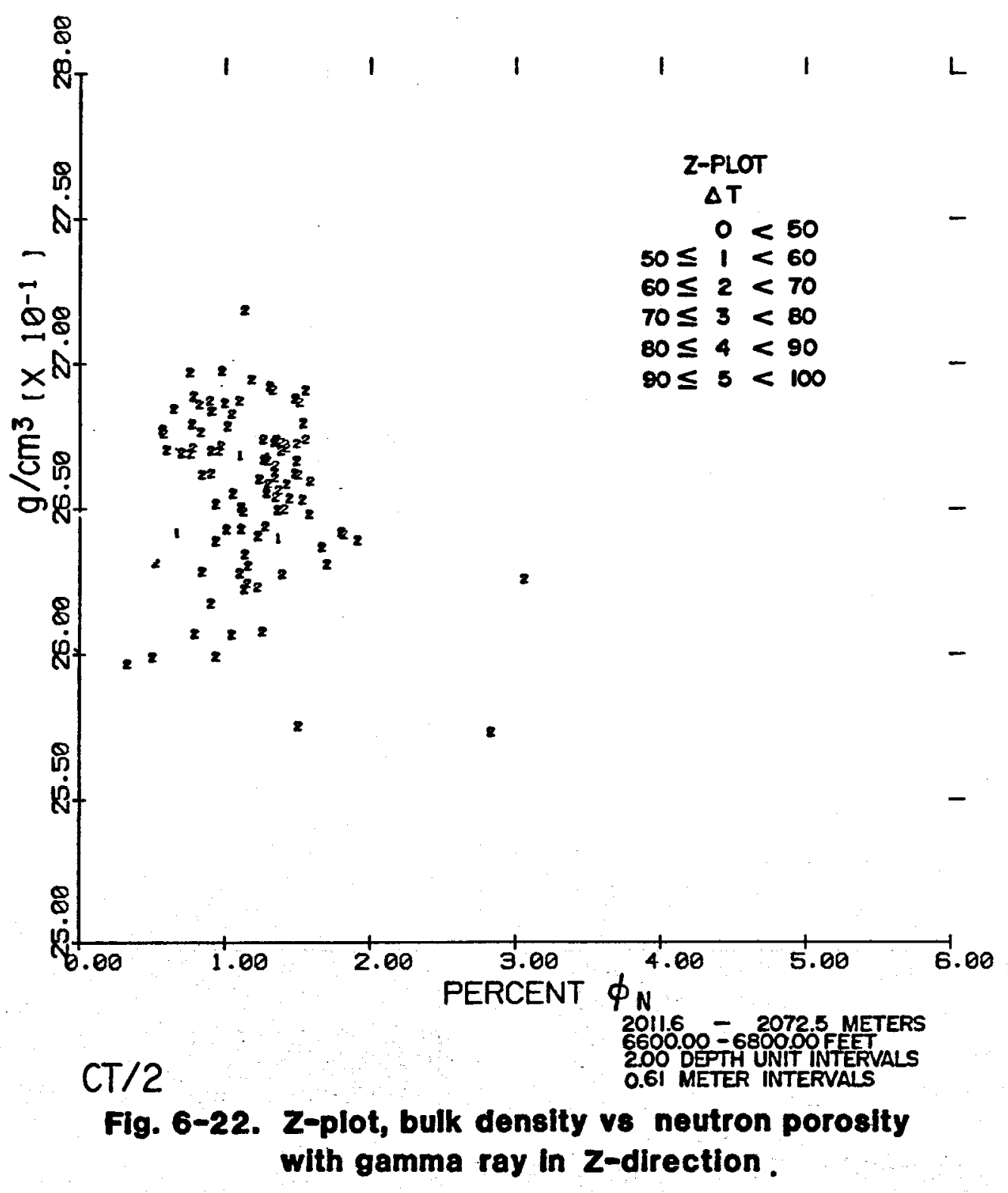




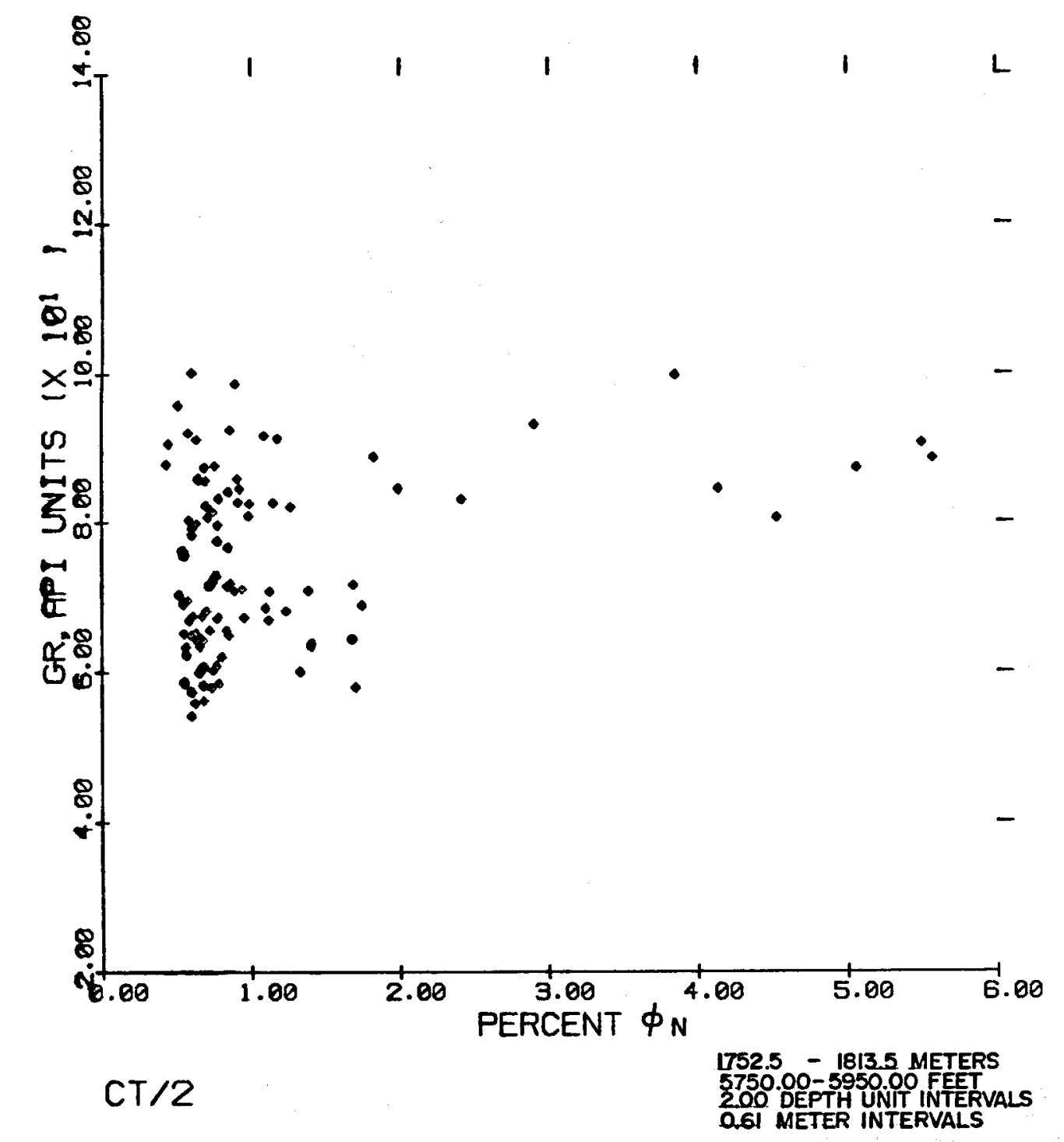

Fig. 6-23a. Gamma ray ve neutron porosity . 


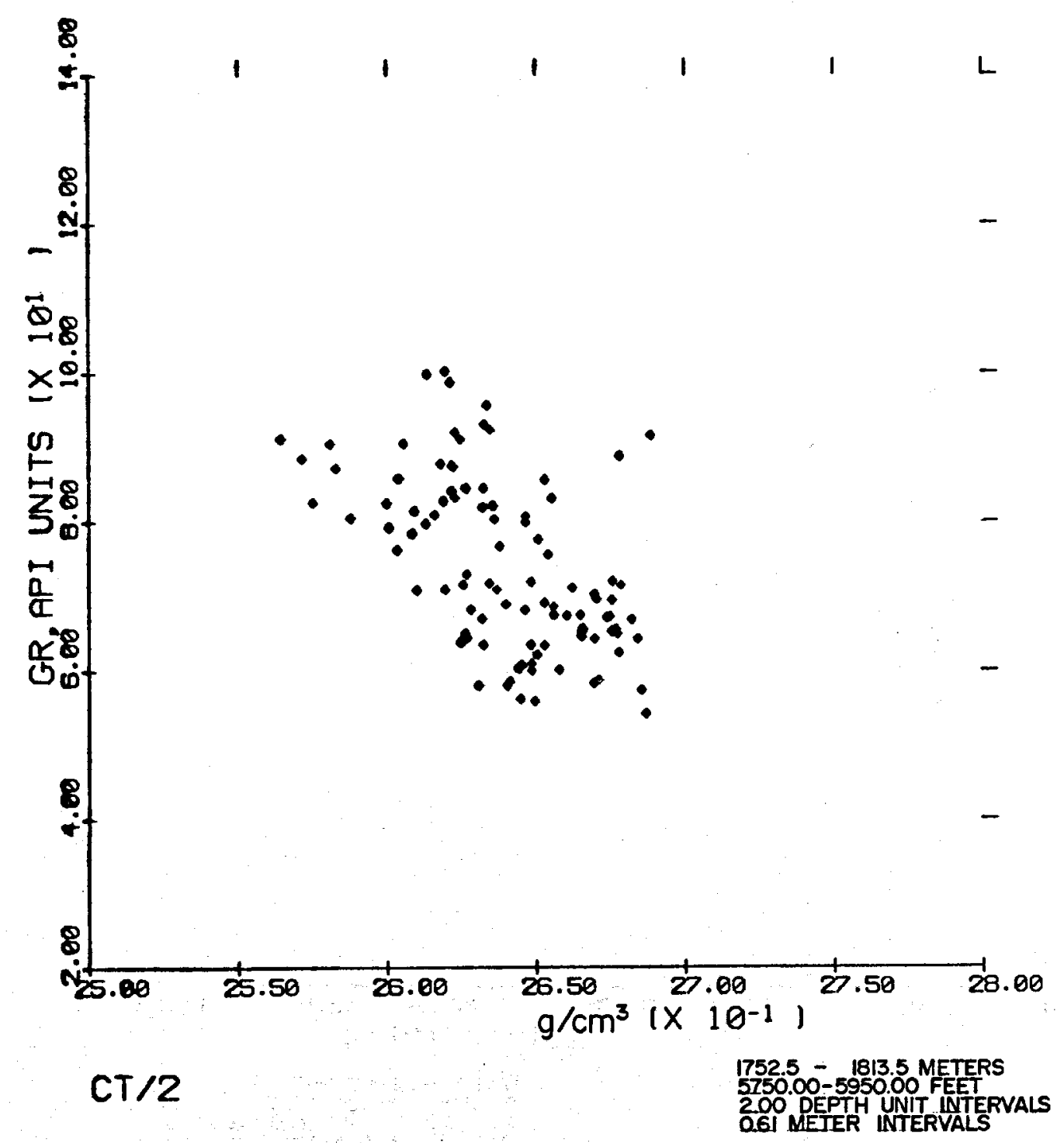

Fig. 6-23b. Gamma ray v8 bulk density . 


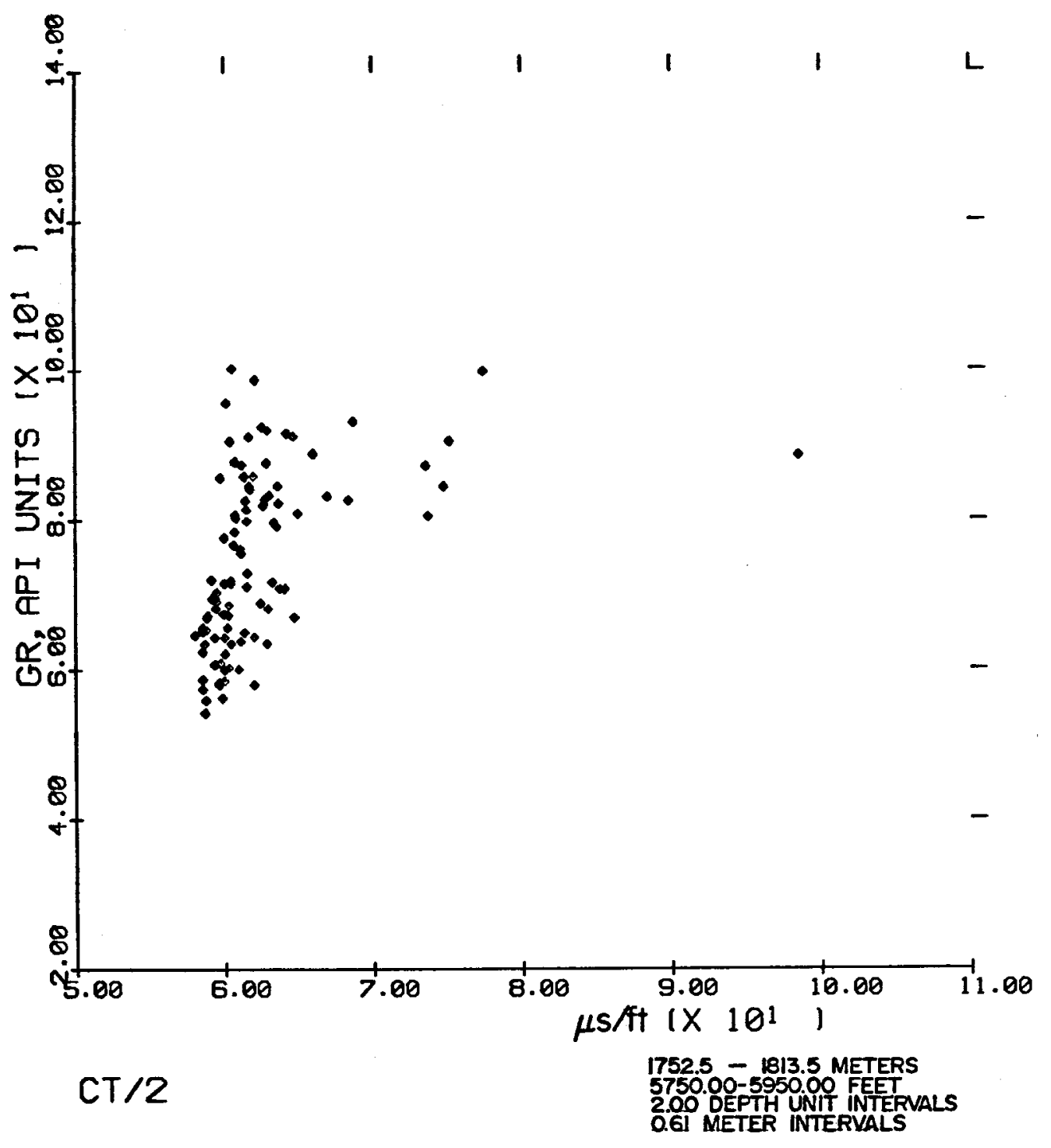

Fig. 6-23c. Gamma ray ve interval transit time. 


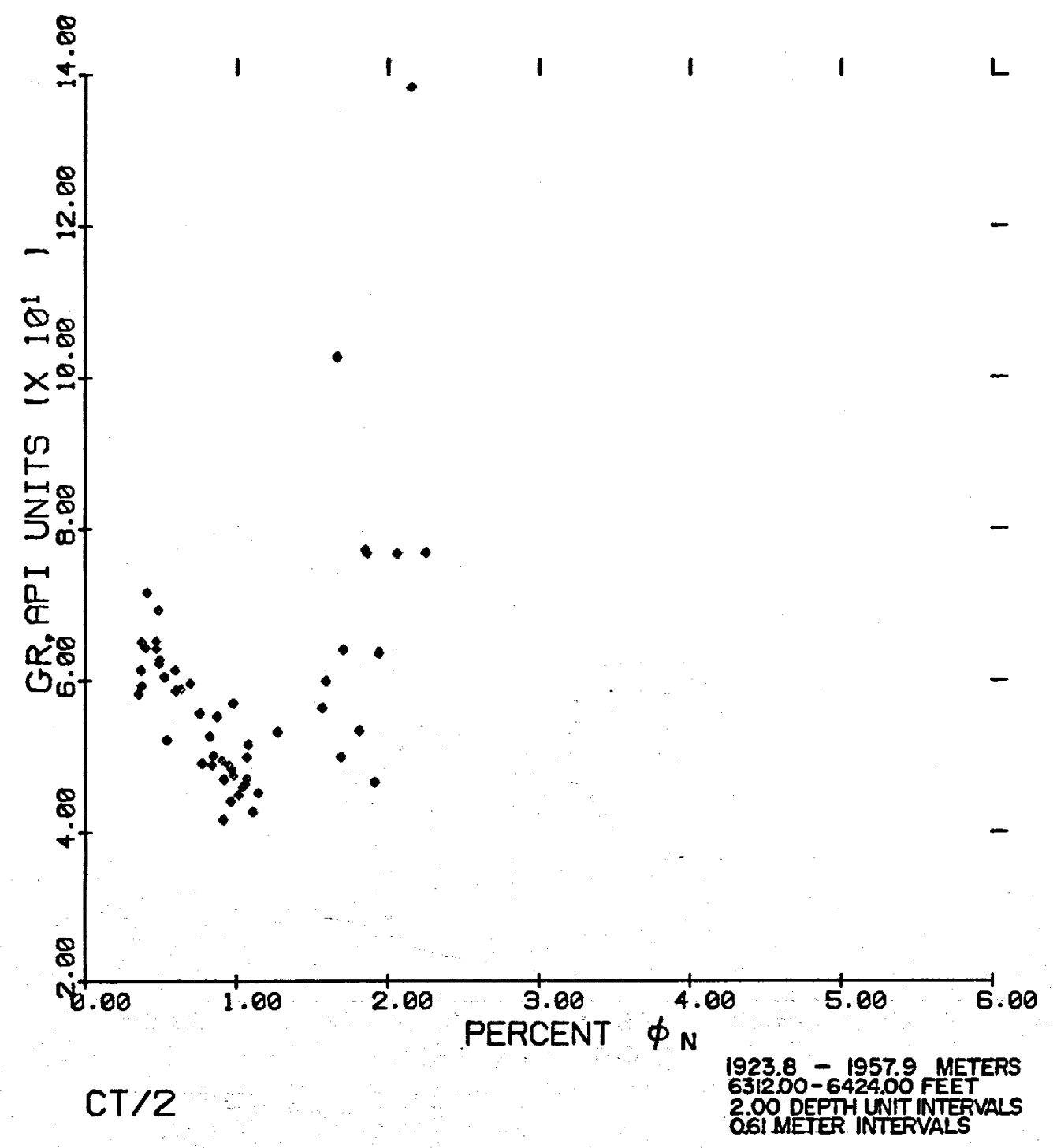

Fig. 6-24a. Gamma ray vs neutron porosity. 


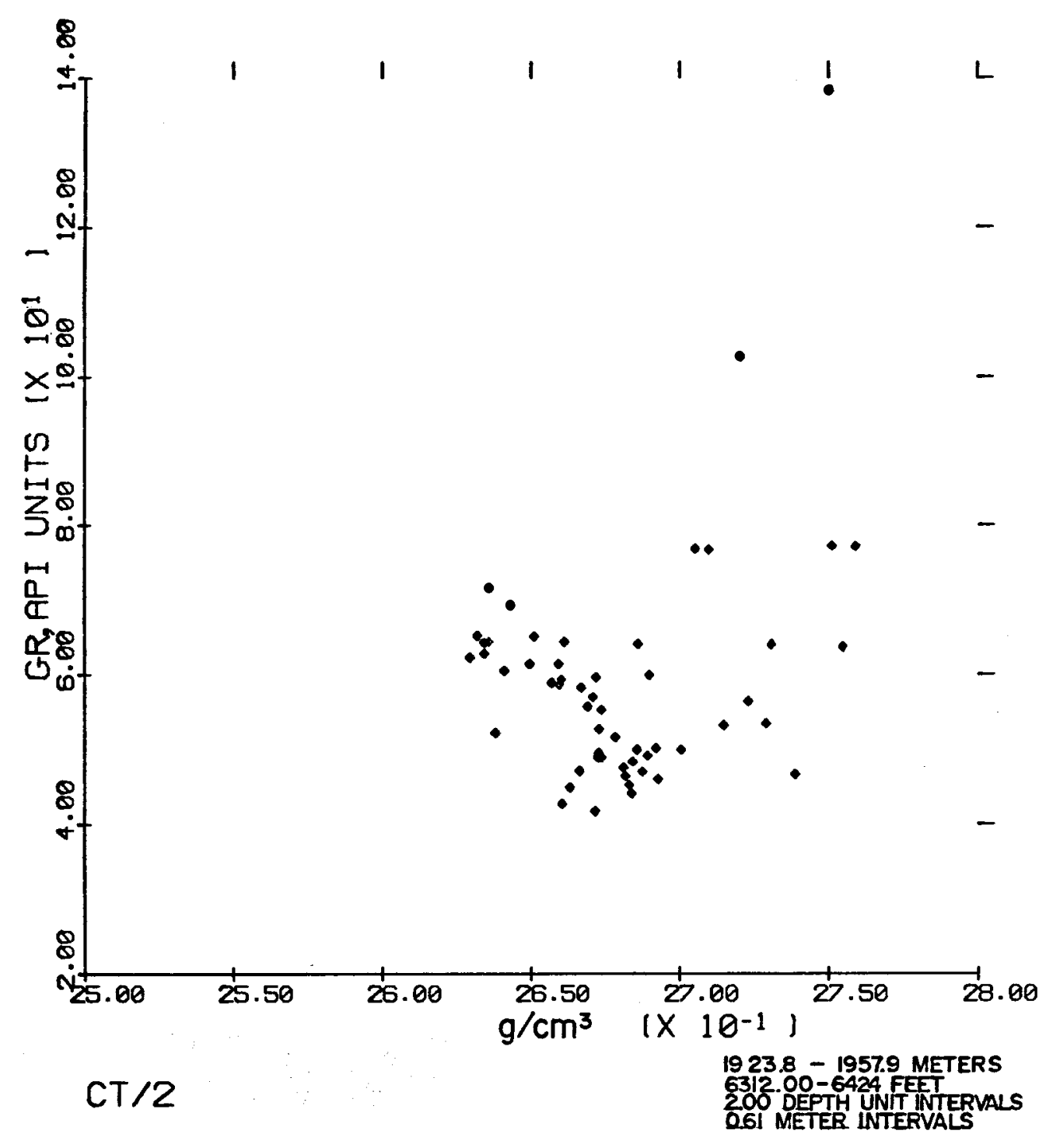

Fig. 6-24b. Gamma ray vo bulk density . 


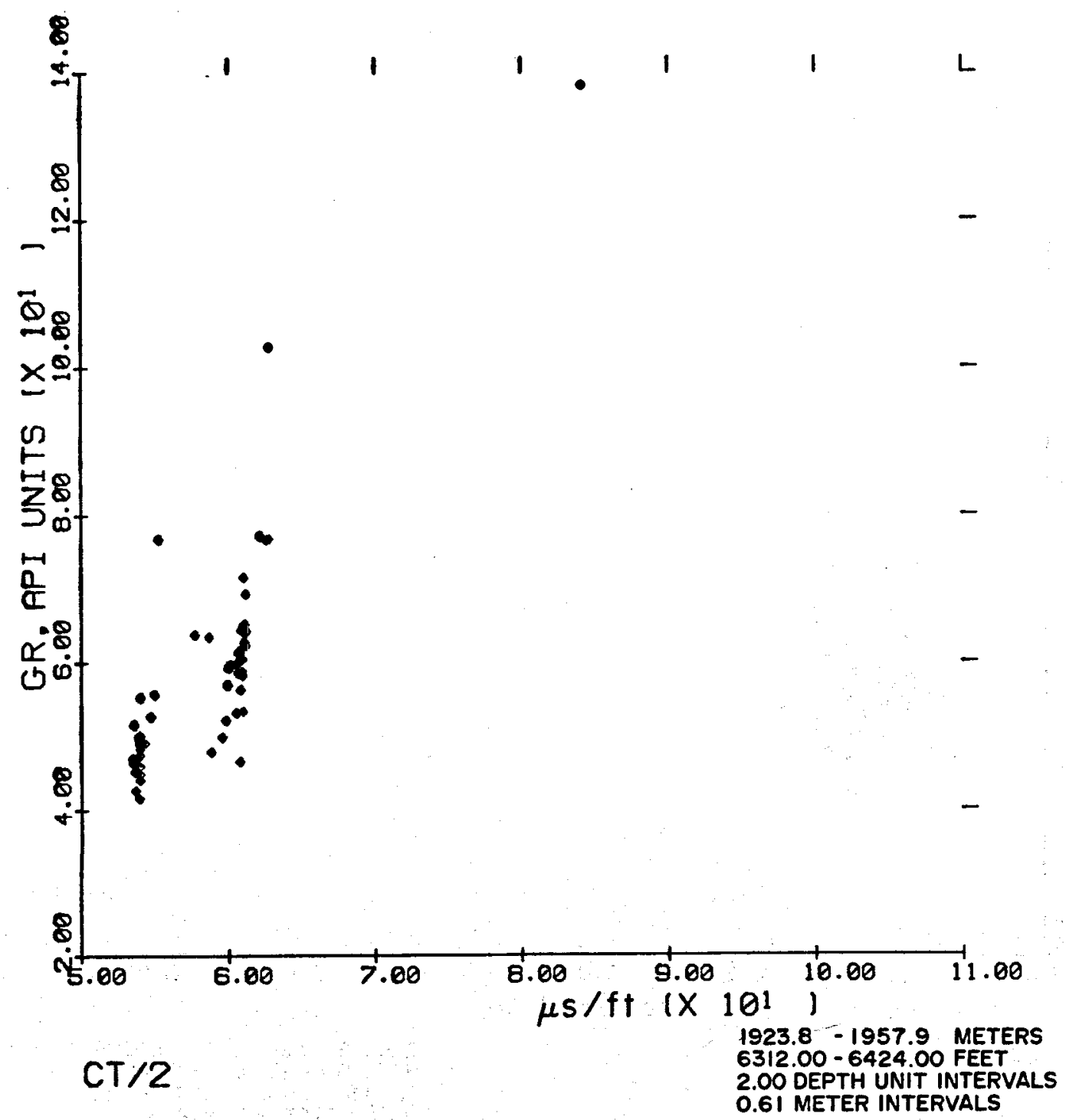

Fig. 6-24c. Gamma ray ve interval transit time. 


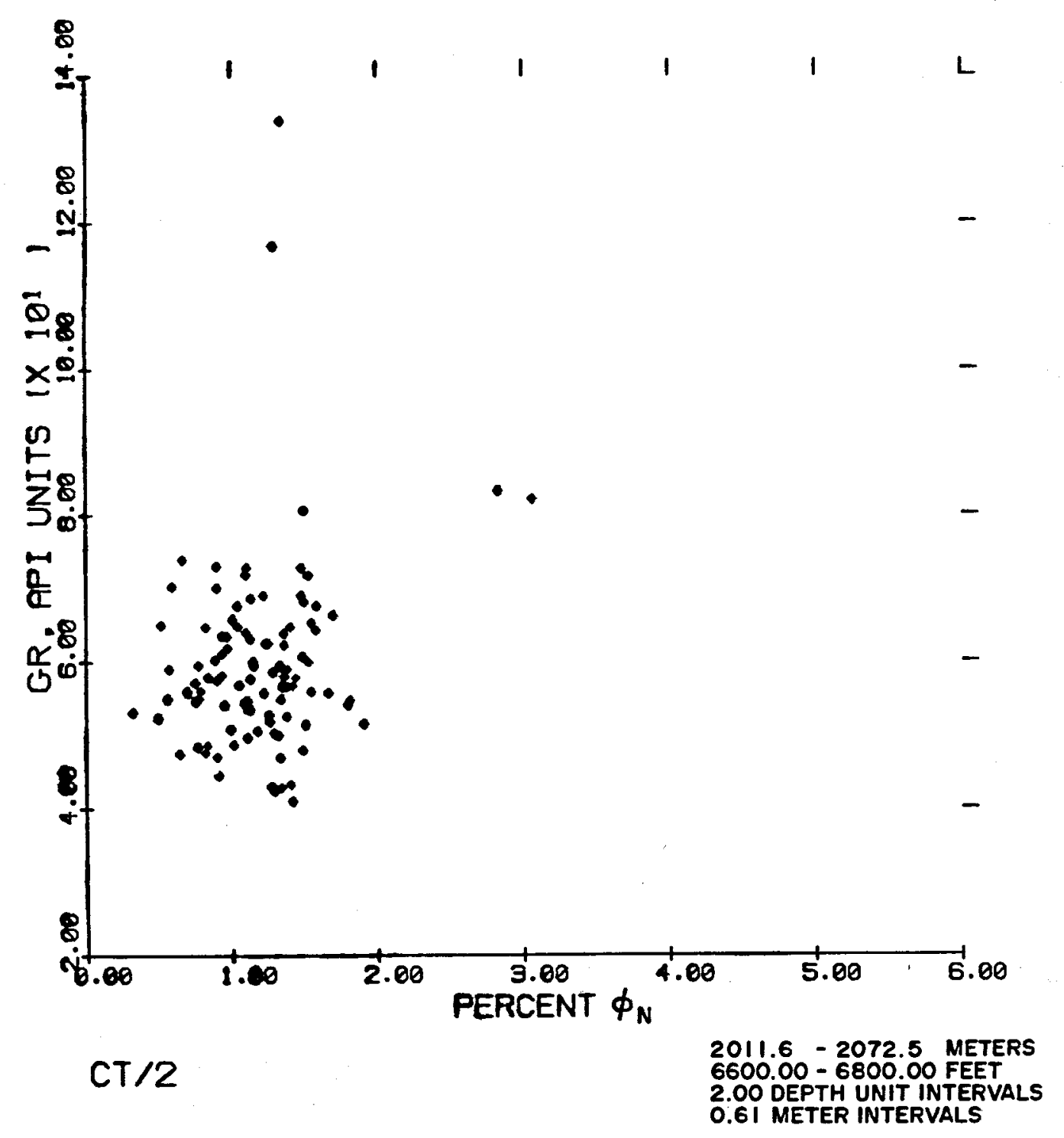

Fig. 6-25a. Gamma ray vs neutron porosity . 


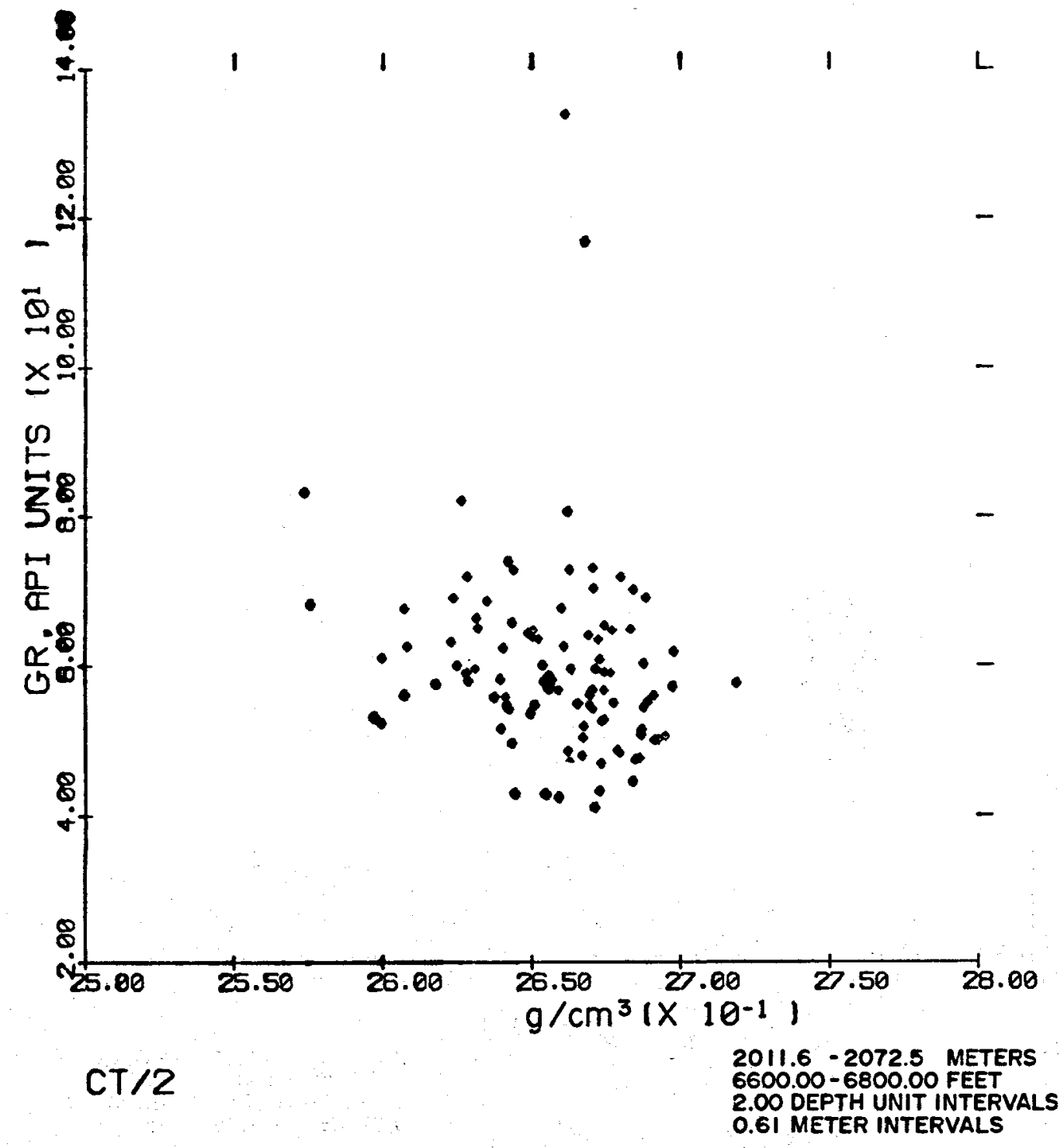

Fig. 6-25b. Gamma ray vo bulk density . 


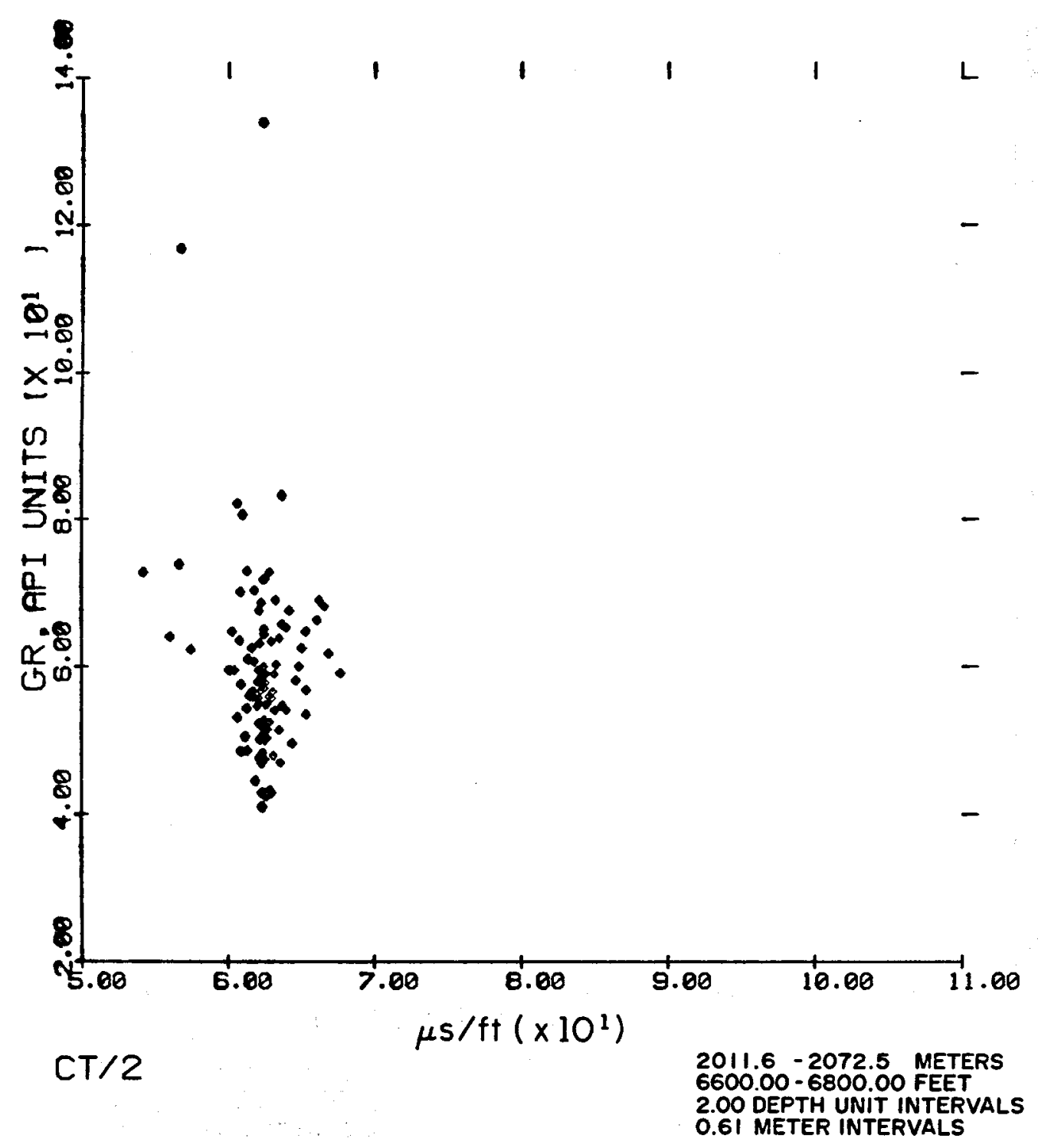

Fig. 6-25c. Gamma ray vs interval transit time . 
7. Log Data-Chemical Data Cross Plots. Various cross plots were constructed between density, neutron and gamma-ray logs and $\mathrm{K}_{2} \mathrm{O}, \mathrm{Fe}_{2} \mathrm{O}_{3}, \mathrm{MgO}$, Li and Loss data where Loss is assumed to be water lost during fusion of the sample. The more interesting plots are presented here. The same three intervals studied above are used except only those portions of the intervals that have chemical data are plotted. The log data were averaged on $3.1 \mathrm{~m}$ (10 ft) intervals to correspond to the chip sample interval length used for the chemical analyses.

The three interval plots of $\mathrm{K}_{2} 0$ versus gamma-ray data are shown in Figs. 6-26, 6-27 and 6-28. With few exceptions, mostly in the deepest interval, the gamma-ray and $\mathrm{K}_{2} \mathrm{O}$ data correlate quite well. This correlation has been used for lithologic identification in mineralized igneous rocks using well logs (Glenn and Nelson, 1977). We will show that in three short intervals, believed to be fracture or fault intercepts, the gamma-ray response is part]y due to uranium and thorium and/or their daughters.

The bulk density $\log$ data were plotted versus $\mathrm{Fe}_{2} \mathrm{O}_{3}$ and $\mathrm{MgO}$ data in Fig. 6-28 and good correlation was evident between the log data and both substances. Therefore, plots were made between the logs and a sum of $\mathrm{Fe}_{2} \mathrm{O}_{3}$ and $\mathrm{MgO}$. These plots are shown in Figs. 6-29, 6-30 and 6-31. Both $\mathrm{Fe}_{2} \mathrm{O}_{3}$ and MgO are present predominantly in the hydrous mafic minerals. Some iron, although reported as $\mathrm{Fe}_{2} \mathrm{O}_{3}$, occurs in magnetite as $\mathrm{Fe}_{3} \mathrm{O}_{4}$. In either case, the correlation between density and $\mathrm{Fe}_{2} \mathrm{O}_{3}$ and $\mathrm{MgO}$ is expected.

Lithium was also plotted versus the gamma-ray data and exhibits a good correlation which suggests the lithium is in the potassium feldspar. It can also occur in the mica lepidolite.

Neutron porosity data were plotted versus the Loss observed in the chemical analyses (Figs. 6-32, and 6-33). The Loss is assumed to be largely water, both pore and bound. Since tlie analyses were done on chips, the water loss is primarily bound water. Although the correlation is not particularly good, the level of loss indicates enough bound water is present to explain most of the neutron response.

Two plots of chemical data are shown in Figs. $C$ and $D$ at $12 \mathrm{~m} / \mathrm{cm}(100$ $\mathrm{ft} / \mathrm{in}$.). These plots enable one to make a direct comparison of the chemical data to the $\log$ data in Fig. B. Only data that have demonstrated some correlation have been included in the plots. 


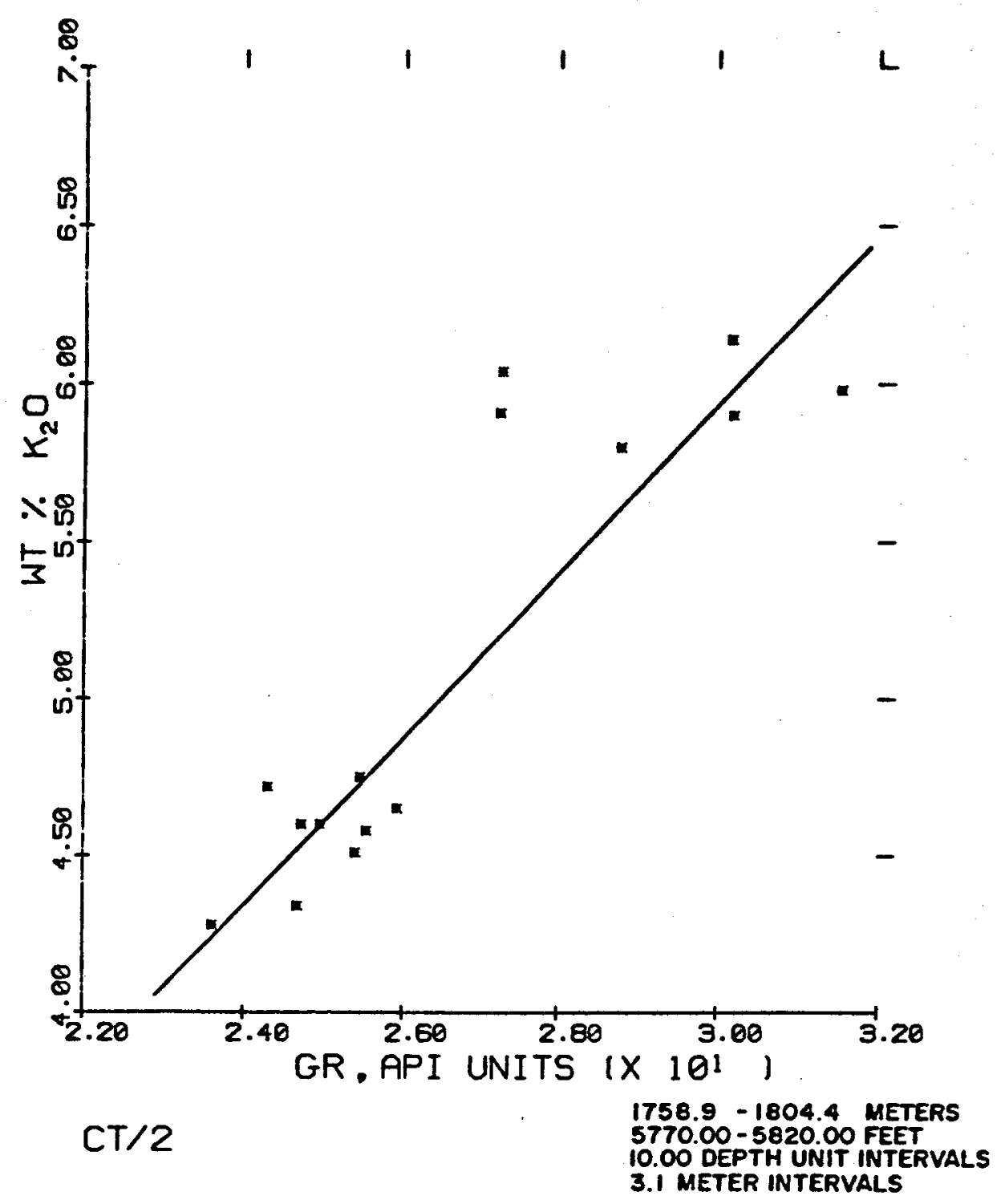

Fig. 6-26. Gamma ray ve $K_{2} \mathrm{O}$. 


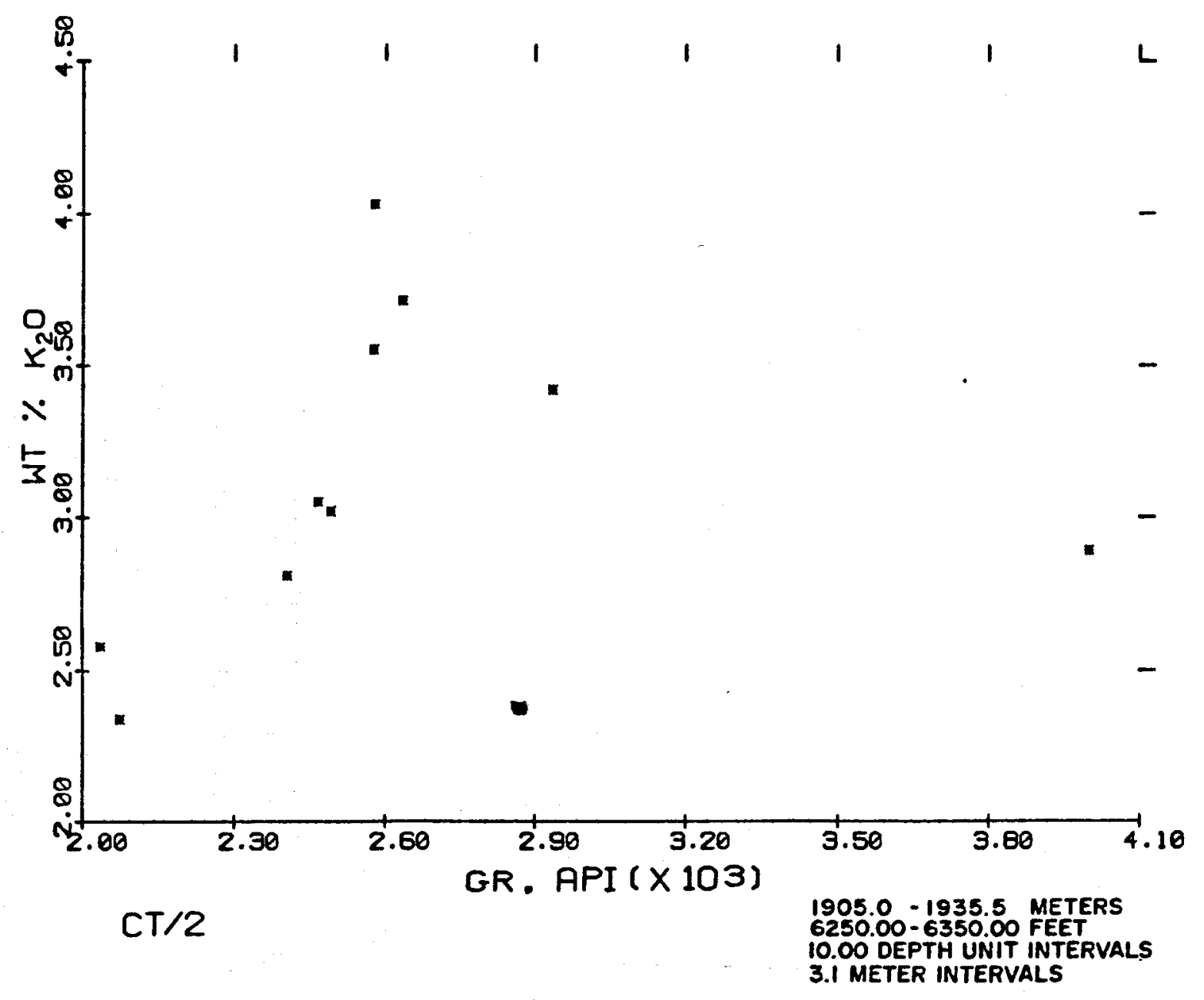

Fig. 6-27. Gamma ray v8 $\mathrm{K}_{2} \mathrm{O}$. 
홍

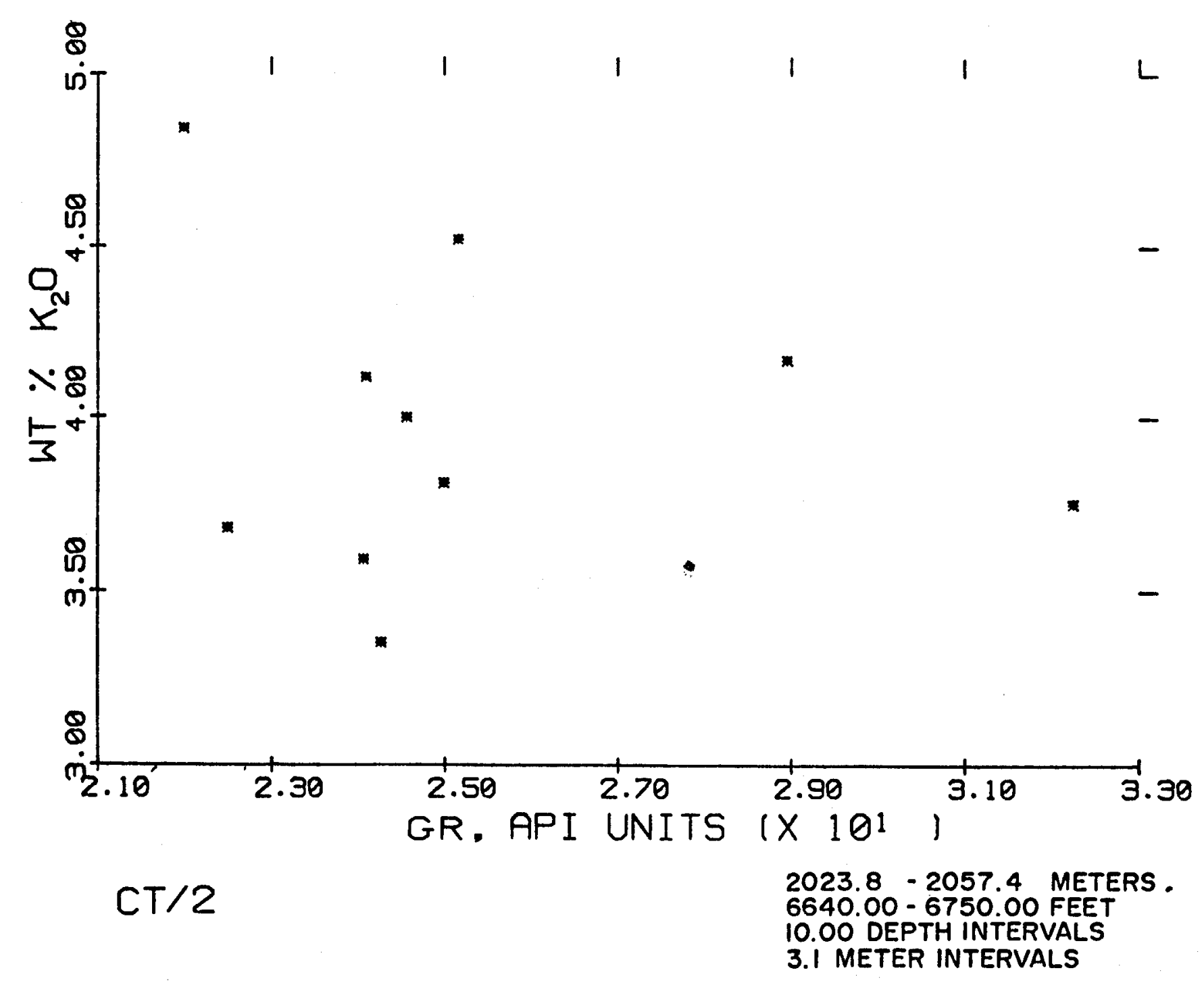

Fig. 6-28. Gamma ray vs $\mathrm{K}_{2} \mathrm{O}$. 


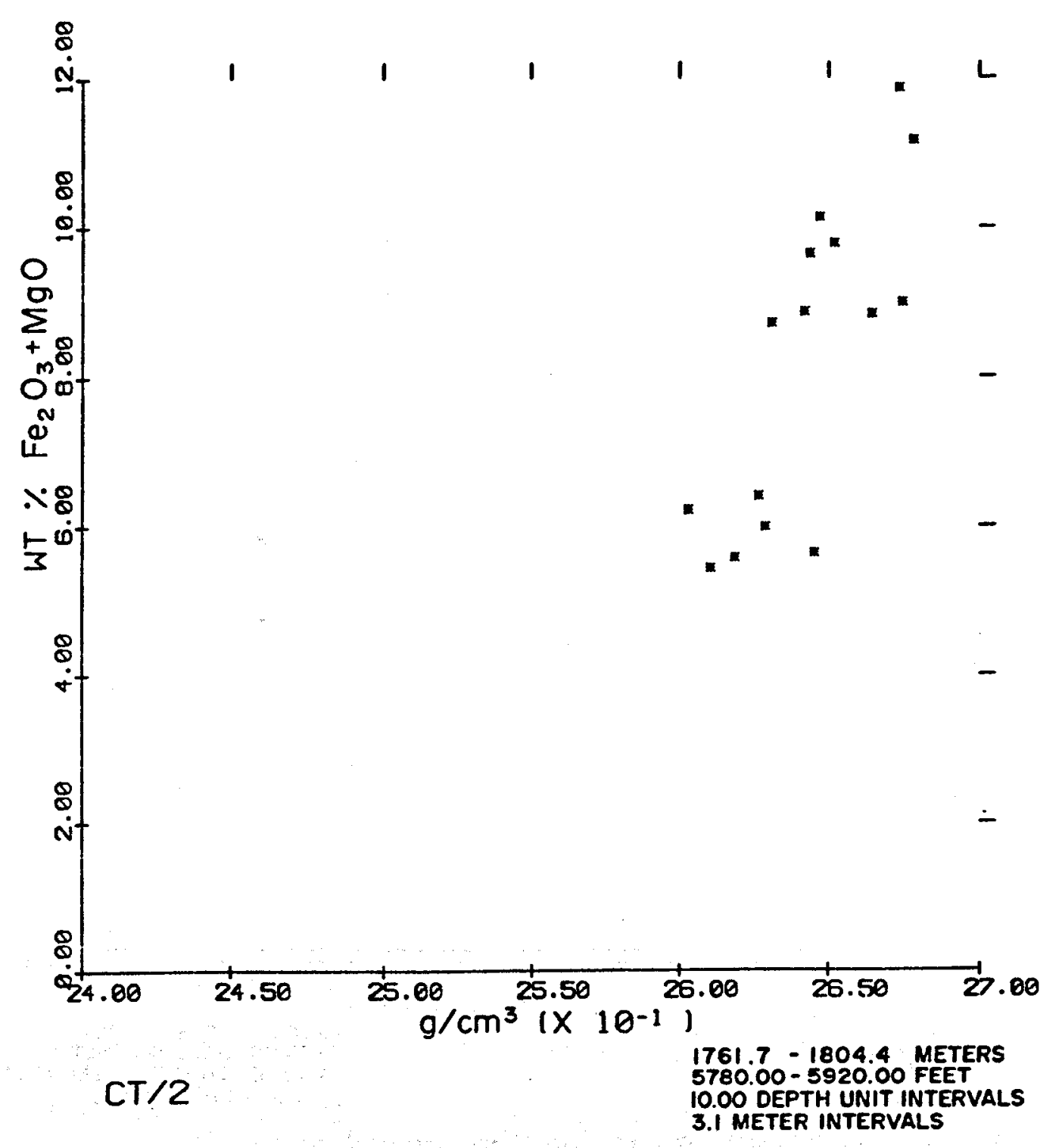

Fig. 6-29. $\mathrm{F}_{2} \mathrm{O}_{3} \bullet \mathrm{MgO}$ v8 bulk density. 


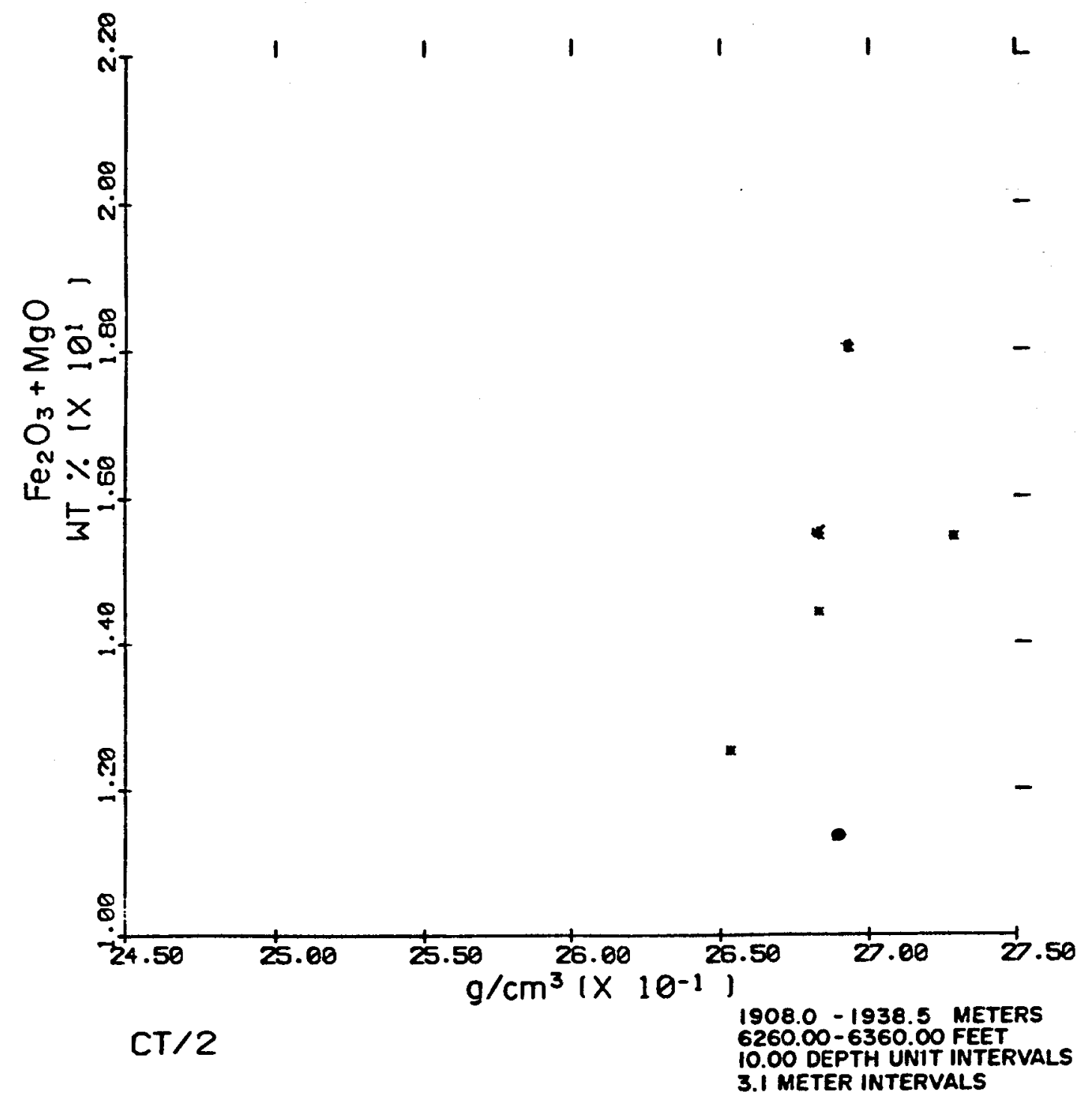

Fig. 6-30. $\mathrm{Fe}_{2} \mathrm{O}_{3} \mathrm{MgO}$ ve bulk density . 


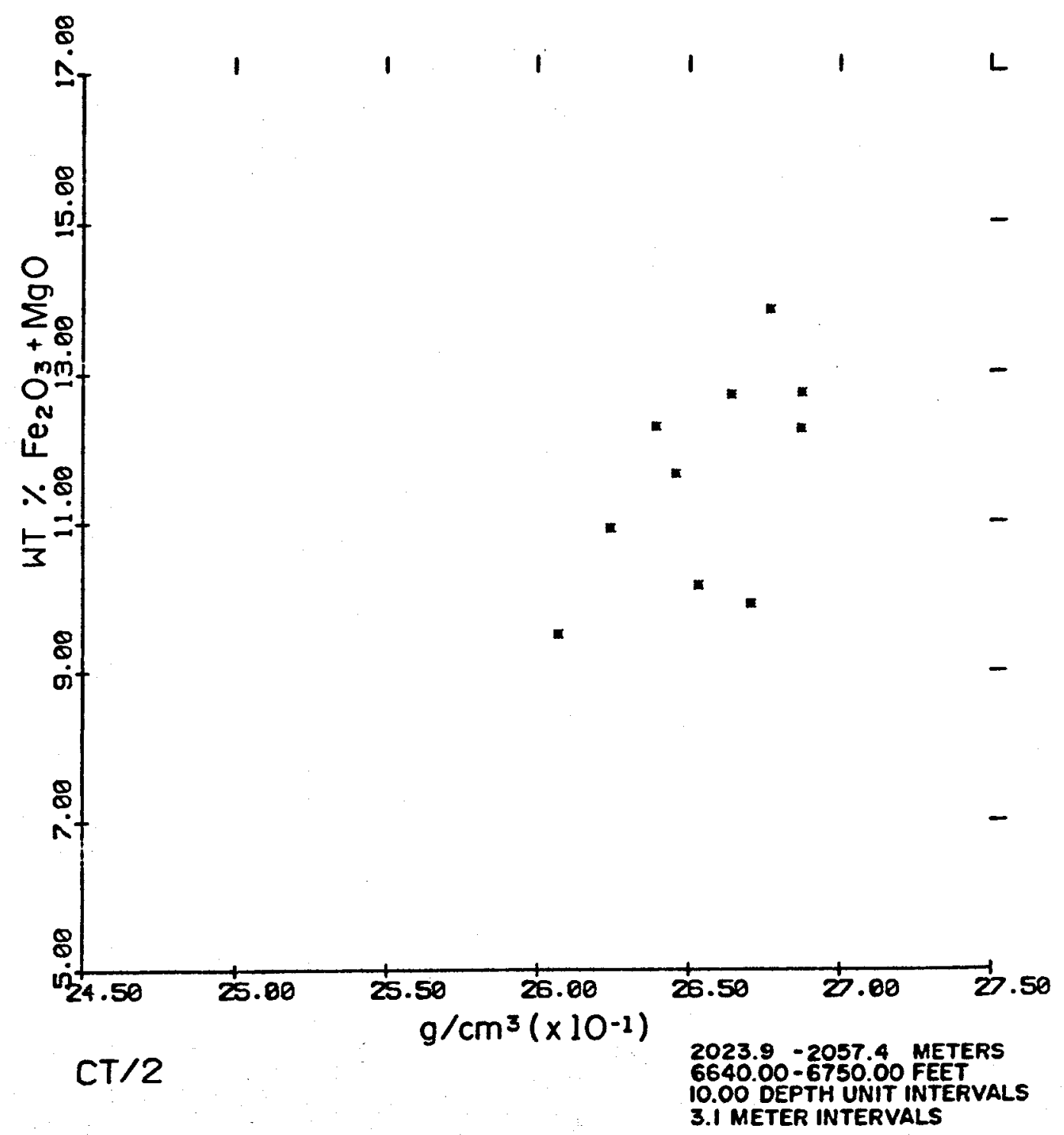

Fig. 6-31. $\mathrm{FO}_{2} \mathrm{O}_{3}+\mathrm{MgO}$ vs bulk density . 


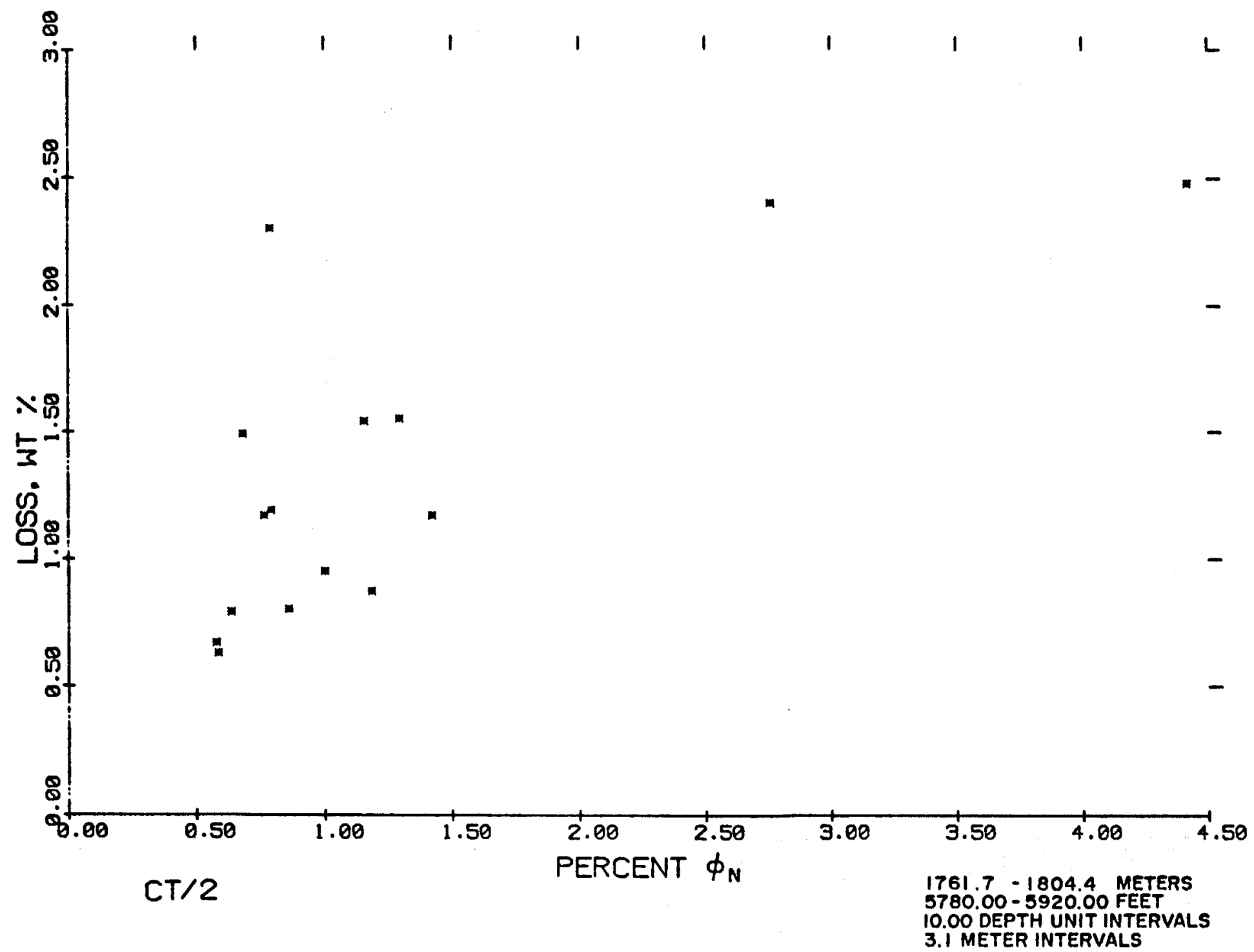

Fig. 6-32. Loss vs neutron porosity. 

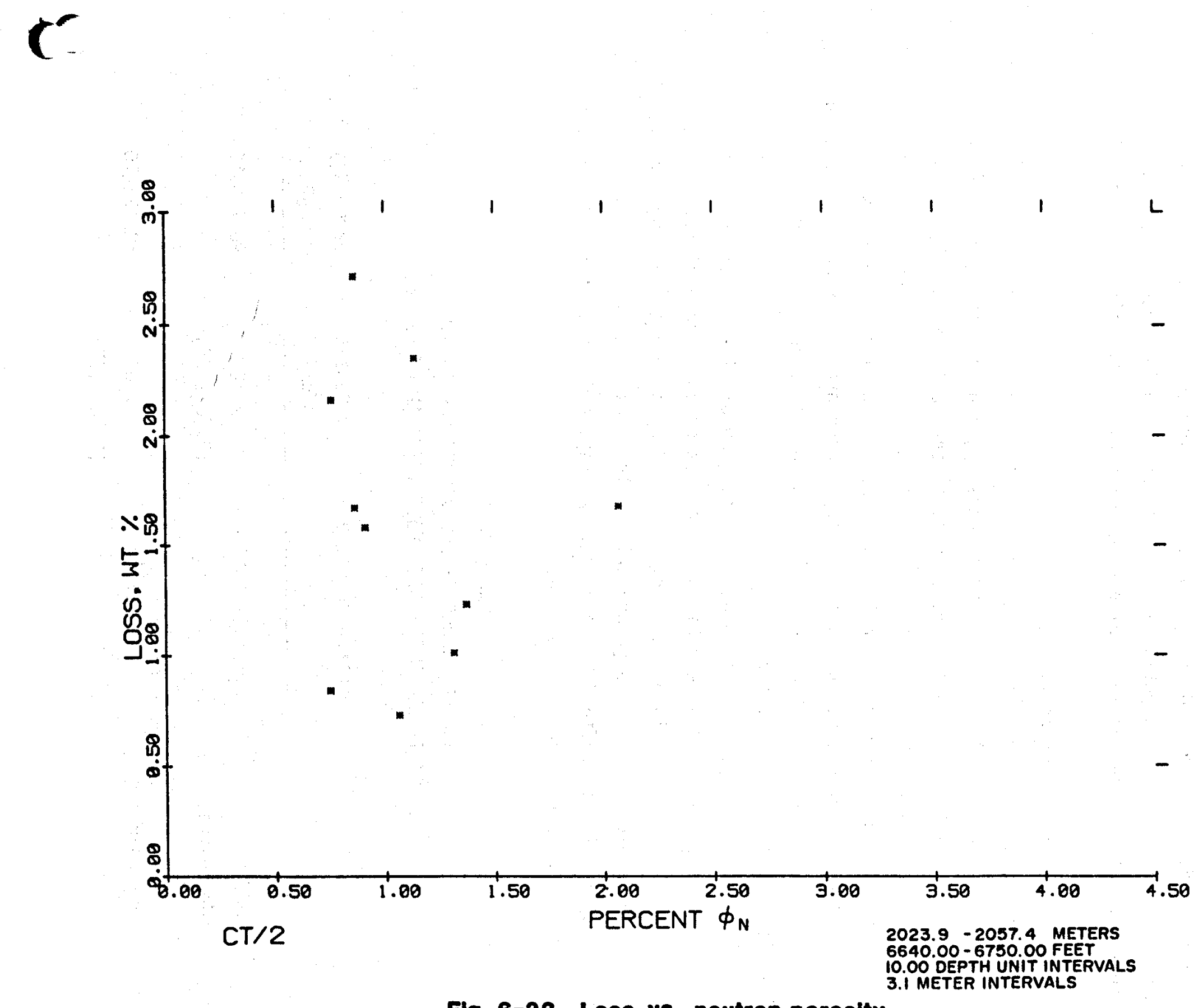

Fig. 6-33. Loss vs neutron porosity . 
The chemical data clearly mark the rock contact at $1917.2 \mathrm{~m}(6290 \mathrm{ft})$ and the several interpreted fracture or fault intercepts at $1453.9 \mathrm{~m}(4770 \mathrm{ft})$, $1767.8 \mathrm{~m}(5800 \mathrm{ft})$ and $1920.2 \mathrm{~m}(6300 \mathrm{ft})$. Uranium and thorium and/or their daughters, in addition to potassium, are concentrated in these intervals. These elements may be mostly in alteration minerals, primarily $\mathrm{clay}$ minerals.

\section{Summary of Log Interpretations}

Various standard well log data interpretation cross plots were constructed from the LASL C/T-2 neutron, density, acoustic and gamma-ray well logs. Cross plots of log data versus selected chemical data were plotted.

Neutron and density $\log$ cross plots were interpreted in terms of both porosity and dense, hydrous mineral variations. In typical, low porosity igneous and metamorphic rocks, these two logs' response are principally due to mineralogic variations in the rocks. The logs obtained in C/T-2 further illustrate this characteristic.

The two rock types, quartz monzonite and granodiorite, occurring in the open hole interval of C/T-2 exhibit distinct responses on several logs. The quartz monzonite has a higher gamma-ray, lower density, lower neutron porosity and a lower velocity than the granodiorite. The rock contact at $1917.2 \mathrm{~m}$ $(6290 \mathrm{ft})$ is clearly defined by each log. Average and range of log values for each rock type are listed in Table 6-VI.

TABLE 6-VI

AVERAGE AND RANGE OF LOG VALUES FOR THE TWO ROCK TYPES IN THE OPEN HOLE INTERVAL OF C/T-2

\begin{tabular}{|c|c|c|c|}
\hline & $\begin{array}{c}\text { Neutron Porosity } \\
\%\end{array}$ & $\begin{array}{c}\text { Bulk Density } \\
\mathrm{g} / \mathrm{cm}^{3}\end{array}$ & $\begin{array}{c}\text { Gamma Ray } \\
\text { API }\end{array}$ \\
\hline Quartz & $.5(0-1)$ & 2.62 & $90(70-100)$ \\
\hline Monzonite & & $(2.58-2.66)$ & \\
\hline Granodiorite & $1.5(1-3)$ & $\begin{array}{c}2.68 \\
(2.64-2.73)\end{array}$ & $50(30-70)$ \\
\hline
\end{tabular}


The resistivity and SP logs, in addition to the above logs, mark three possible fracture or fault intercepts in the open hole interval which are centered at $1453.9 \mathrm{~m}(4770 \mathrm{ft}), 1767.8 \mathrm{~m}(5800 \mathrm{ft})$ and $1920.2 \mathrm{~m}(6300 \mathrm{ft})$. The first two are clearly identified by analyses of chip samples by the presence of gouge.

The resistivity $\log$ indicates the rocks have a resistivity of $100 \mathrm{ohm}-\mathrm{m}$ or greater. The log was obtained with a decentralized induction tool and the data are probably inaccurate. Induction logs in other Roosevelt holes exhibited similar limitations (Glenn and Hulen, 1979). In these holes resistivity $\log$ saturation occurred at 1500 to 2000 ohm-m. Unfortunately, the high temperature of geothermal wells limits the choice of electric logs.

Computed acoustic velocities for the granodiorite are not valid since the first arrival was not used for the log. However, the computed acoustic velocity for the quartz monzonite averages $5.0 \mathrm{~km} / \mathrm{s}$ and ranges between 4.8 and $5.2 \mathrm{~km} / \mathrm{s}$. These results are consistent with velocities determined in other Roosevelt Hot Springs geothermal wells (Glenn and Hulen, 1979). 
Completion of this study would have been impossible without valuable contributions from many of our associates at the Earth Science Laboratory and the University of Utah Department of Geology and Geophysics. H. Crecraft, J. M. Ballantyne and S. H. Evans facilitated obtaining and interpreting microprobe analyses of selected rock-forming and alteration minerals. We thank F. Brown and J. Mason for chemical analyses by $X$-ray fluorescence. Mason also prepared clay separates of selected samples and analyzed them by $X$-ray diffraction. R. Kroneman completed arsenic analyses by colorimetry and all analyses by plasma spectrometry. Mercury analyses were done by $B$. Cerling. Carbon and oxygen isotopic analyses were completed by D. Rohrs and interpreted by $D$. Cole, who also wrote most of Section IV of this report. Chemical and Mineralogical Services, Salt Lake City, provided potassium, uranium and thorium analyses by closed-can gamma-ray spectrometry and uranium analyses by fluorometry. T. Dustman measured magnetic susceptibilities and densities. W. Wilson and D. Chapman provided thermal conductivity measurements. J. Atwood, M. Diely and M. Hyland contributed to digitizing, checking and plotting the well log data. Illustrations were prepared by $D$. Cullen and D. Bolaris. The manuscript was typed by H. Baker and L. Stout. 


\section{REFERENCES}

Allen, L. S., and Mills, Jr., W. R., "Measurement of thermal neutron absorption cross section of rock samples by a pulsed source method", SPWLA Fifteenth Ann. Logging Symp., June 2-5, Paper B. (1971).

Ballantyne, J. M., "Hydrothermal alteration at the Roosevelt Hot Springs thermal area, Utah: modal mineralogy, and geochemistry of sericite, chlorite and feldspar from al tered rocks, Thermal Power co. Well Utah State 14-2", Univ. of Utah Dept. of Geology and Geophysics Rept., Salt Lake City, 42 p. (1978).

Ballantyne, J. M., and Parry, W. T., "Hydrothermal alteration at the Roosevelt Hot Springs thermal area, Utah: petrographic characterization to 2 kilometers' depth", Univ. of Utah Dept. of Geology and Geophysics Rept., Salt Lake City, 21 p. (1978).

Ballantyne, G. H., "Hydrothermal alteration at the Roosevelt Hot Springs thermal area, Utah: characterization of rock types and alteration in Getty 0il Company well Utah State 52-21", Univ. of Utah Dept. of Geology and Geophysics Rept., Salt Lake City, 24 p. (1978).

Bamford, R. W., "Geochemistry of solid materials from two U. S. geothermal systems and its application to exploration", Univ. of Utah Research Inst., Earth Science Laboratory, Rept. 6, Salt Lake City, 196 p. (1978).

Bamford, R. W., Christensen, 0. D., and Capuano, R. M., "Multielement geochemistry of solid materials in geothermal systems and its applications Part 1: The hot-water system at the Roosevelt Hot Springs KGRA, Utah", Univ. of Utah Research Inst., Earth Science Laboratory Rept. 30, Salt Lake City, (1980).

Bence, A. E., and Albee, A. L., "Empirical correction factors for the electron microanalysis of silicates and oxides", Jour. Geol. v. 76, p. 382-403 (1968). 
Bethke, P. M., and Rye, R. 0., "Environment of ore deposition in the Creede mining district, San Juan Mountains, Colorado: Part IV. Source of fluids from oxygen, hydrogen and carbon isotope studies": Econ. Geology, v. 74, p. 1832-1851, (1979).

Bottinga, Y., "Calculation of fractionation factors for carbon and oxygen isotopic exchange in the system calcite-carbon dioxide-water": J. Phys. Chem., v. 72, p. 800-808, (1968).

Bryant, N. L., and Parry, W. T., "Hydrothermal alteration at Roosevelt Hot Springs KGRA--DDH 1976-1", Univ. of Utah Dept. of Geology and Geophysics Rept., Salt Lake City, 87 p. (1977).

Burke, J. A., Schmidt, A. W., and Campbell, Jr., R. L., "The litho-porosity crossplot"; The Log Analyst, Nov.-Dec., 1969, also in SPWLA Reprint v. Gamma Ray, Neutron and Density Logging, March (1978).

Casadevall, T., and Ohmoto, H., "Sunnyside mine, Eureka mining district, San Juan County, Colorado: Geochemistry of gold and base metal ore formation in the volcanic environment": Econ. Geology, v. 72, p. 1285-1320, (1977).

Craig, H., "Isotopic standards for carbon and oxygen and correction factors for mass-spectrometric analysis of carbon dioxide": Geochim. Cosmochim. Acta, v. 12, p. 133-149, (1957).

Craig, H., "Standard for reporting concentrations of deuterium and oxygen-18 in natural waters": Science, v. 133, no. 3467, p. 1833-1834 (1961).

Dresser Atlas, "Log Interpretation Charts", Dresser Industries, Inc., Houston, Texas, p. 107, (1979).

Dresser Atlas, "personal communication", (1980). 
Edmundson, H., and Raymer, L. L., "Radioactive logging parameters for common minerals": SPWLA Twentieth Annual Logging Symposium Transactions, Paper 0 , (June, 1979).

Elders, W. A., Hoagl and, J. R., and 01son, E. R., "Hydrothermal mineralogy and isotope chemistry in the Cerro Prieto Field, Mexico, III, Practical applications", Trans. Geotherm. Res. Council, v. 2, p. 177-180. (1978).

Ewers, G. R., and Keays, R. R., "Volatile and precious metal zoning in the Broadlands geothermal field, New Zealand", Econ. Geology, v. 72, p. 1337-1354, (1977).

Fournier, R. 0., "Geochemical and hydrologic considerations and the use of enthalpy-chloride diagrams in the prediction of undergound conditions in hot-spring systems": J. Volcanol. Geotherm. Res., v. 5, p. 1-16 (1979).

Friedman, I., and $0^{\prime} \mathrm{Neill,} \mathrm{J.} \mathrm{R.,} \mathrm{"Compilation} \mathrm{of} \mathrm{stable} \mathrm{isotope} \mathrm{fractionation}$ factors of geochemical interest", U. S. Geol. Survey Prof. Paper 440-KK, (1976).

Gearhart-Owen, "Formation Evaluation Data Handbook, 1978 Edition," Gearhart-Owen Industries, Inc., Fort Worth, Texas, (1978).

Glenn, W. E., and Hulen, J. B., "Interpretation of well log data from four drill holes at Roosevelt Hot Springs KGRA", Univ. of Utah Res. Inst., Earth Sience Laboratory Rept. 28, Salt Lake City, 74 p. (1979a).

Glenn, W. E., and Nelson, P. H., "Borehole logging techniques applied to base metal ore deposits": Exploration 77 Symposium, Ottawa, Canada (1977) and in Geol. Surv. of Canada Economic Geology Rept. 31, p. 273-294 (1979). 
Hulen, J. B., "Stratigraphy and alteration, 15 shallow thermal gradient holes, Roosevelt Hot Springs KGRA and vicinity, Millard and Beaver Counties, Utah": Univ, of Utah Res. Inst., Earth Science Laboratory Rept. 9, Salt Lake City, 14 p. (1978).

Jack, R. N., and Carmichael, I. S. E., "The chemical "fingerprinting" of acid volcanic rocks", in short contributions to California geology, Calif. Div. Mines and Geology Spec. Rept. 100, p. 17-32, (1969).

James, G. W., "Parts-per-million determinations of uranium and thorium in geologic samples by $\mathrm{x}$-ray spectrometry", Analytical Chem., v. 49, p. 967-968, (1977).

Kendall, C., "Petrology and stable isotope geochemistry of three wells in the Buttes area of the Salton Sea geothermal field, Imperial Valley, California, U.S.A.", Univ. of Calif., Riverside, Inst. of Geophys. and Planet. Phys. Rept. UCR/IGPP-76/17, 211 p., (1976).

Kowalski, J. J., "Formation strength parameters from well logs", SPWLA Symp. Trans., June 4-7, New Orleans, LA, Paper N., (1975).

Lipman, P. W., Rowley, P. D., Mehnert, H. H., Evans, S. H., Nash, W. P., and Brown, F. H., "Pleistocene rhyolite of the Mineral Mountains, Utah--geothermal and archaeological significance": Jour. Res., U. S. Geol. Surv. $\underline{6}$, p. 133-147, (1978).

Mathews, M., "Log responses from the Geothermal Calibration Test Well C/T-2": SPWLA Twentieth Annual Logging Symposium Transactions, v. II, Paper SS (1979).

McCrea, J. M., "The isotopic chemistry of carbonates and a paleotemperature scale": J. Chem. Phys., v. 18, p. 849, (1950).

Newman, K. L., "Calibration/Test well management", Geothermal Log Interpretation Program. First yearly topical report (1979). 
Nielson, D. L., Sibbett, B. S., Mckinney, D. B., Hulen, J. B., Moore, J. N., and Samberg, S. M., "Geology of Roosevelt Hot Springs KGRA, Beaver County, Utah", Univ. of Utah Res. Inst., Earth Science Laboratory Rept. 12, Salt Lake City, 121 p. (1978).

Norrish, K., and Hutton, J. T., "An accurate X-ray spectrographic method for the analysis of a wide range of geologic samples": Geochim. et Cosmochim. Acta, 33, no. 4, p. 431-454, (1969).

Ohmoto, H., and Rye, R. 0., "Isotopes of sulfur and carbon", in Geochemistry of Hydrothermal ore deposits, (Barnes, H. L., ed.), 2nd ed.; New York, Wiley, p. 509-567. (1979)

Parry, W. T., "Mineralogy of the clay fraction from cuttings, Thermal Power Co. well Utah State 14-2", Univ. of Utah Dept. of Geology and Geophysics Rept., 8 p., Salt Lake City, (1978).

Parry, W. T., Ballantyne, J. M., Bryant, N. L., and Dedolph, R. E., "Geochemistry of hydrothermal alteration at the Roosevelt Hot Springs thermal area, Utah," Geochim, Cosmochim. Acta, 44, p. 95-102 (1980).

Parry, W. T., Bryant, N. L., Dedolph, R. E., Ballantyne, J. M., Ballantyne, G. H. Rohrs, D. T., and Mason, J. L., "Hydrothermal alteration at the Roosevelt Hot Springs thermal area, Utah," Univ. of Utah Dept. of Geology and Geophysics Rept., Salt Lake City, 29 p., (1978).

Parry, W. T., Benson, N. L., and Miller, C. D., "Geochemistry and hydrothermal alteration at selected Utah Hot Springs," Univ. of Utah Dept. of Geology and Geophysics Rept., Salt Lake City, 131 p. (1976).

Pickett, G. R., "Pattern recognition as a means of formation evaluation"; SPWLA Fourteenth Annual Logging Symposium. Trans., Paper A. (1973). 
Plewa, S., "Correlation between thermal conductivity and other physical parameters of rocks," in KAPG Geophysical Monograph, A., Adam, editor, Akademcai Kidao, Budapest, (1976).

Poupon, A., Hoyle, W. R., and Schmidt, A. W., "Log analysis of sand-shale sequences--a systematic approach"; J.P.T., July, (1970).

Ratcliffe, E. H., "Thermal conductivities of fused and crystalline quartz," British Jour. Applied Physics, v. 10, p. 22-25, (1958).

Robinson, B. W., "The origin of mineralization at the Tui mine, Te Aroha, New Zealand, in the light of stable isotope studies:" Econ. Geology, v. 69 , p. 910-925, (1974).

Rohrs, D., and Parry, W. T., "Hydrothermal alteration at the Roosevelt Hot Springs Thermal Area, Utah: Thermal Power Co. Well Utah State 72-16," University of Utah Dept. of Geology and Geophysics Rept., 23 p., Salt Lake City, (1978).

Sass, J. H., Lachenbruch, A. H., and Monroe, R. J., "Thermal conductivity of rocks from measurements on fragments and its application to heat-flow determination," Jour. Geophys. Res., v. 76, no. 14, p. 3391-3401, (1971).

Savre, W. C., "Determination of more accurate porosity and mineral composition in complex lithologies with the use of sonic, neutron, and density surveys"; J.P.T., Sept., (1963).

Schl umberger, "Log Interpretation Charts," Schlumberger Limited, New York, p. 92, (1972).

Schlumberger, "Log interpretation, Vol ume II--Applications, "Schl umberger Limited, New York, p. 116, (1974). 
Sibbett, B. S., and Nielson, D. L., "Geology of the central Mineral Mountains, Beaver County, Utah," Univ. of Utah Res. Inst., Earth Science Laboratory Rept. no. 33, Salt Lake City, 42 p. (1980).

Suhr, N. H., and Ingamells, C. 0., "Solution technique for analysis of silicates, "Anal. Chem., 38, p. 730-734., (1966).

Taylor, H. P., "Oxygen and hydrogen isotope relationships in hydrothermal mineral deposits," in Geochemistry of hydrothermal ore deposits, (Barnes, H. L., (ed.)), 2nd ed.: New York, Wiley, P. 236-277, (1979).

Ward, S. H., Parry, W. T., Nash, W. P., Sill, W. R., and Cook K. L., Smith, R. B., Chapman, D. S., Brown, F H., Whelan, J. A., and Bowman, J. R., "A summary of the geology, geochemistry and geophysics of the Roosevelt Hot Springs thermal area, Utah," Geophysics, 43, no. 7, p. 1515-1542, (1978).

Wilson, W. R., and Chapman, D. S., "Thermal studies at Roosevelt Hot Springs, Utah," Univ. of Utah Dept. of Geology and Geophysics, Salt Lake City, (1980).

Zen, E., and Thompson, A. B., "Low-grade regional metamorphism: Mineral equilibrium relations," Ann. Review Earth and Planetary Sciences, $2, p$. 179-212, (1974). 


\begin{tabular}{|c|c|c|c|c|c|c|c|c|c|c|c|}
\hline \multirow{2}{*}{$\begin{array}{l}\text { U.S. GOVERN } \\
\text { Page Range. }\end{array}$} & \multicolumn{7}{|c|}{$\begin{array}{l}\text { Printed in the United States of America } \\
\text { Avaitable from } \\
\text { National Technical Information Service } \\
\text { US Department of Commerce } \\
\text { 5285 Port Royal Road } \\
\text { Springfield, VA 22161 } \\
\text { Microfiche \$3.50 (A01) }\end{array}$} & \multirow[b]{2}{*}{$\begin{array}{c}\text { NTIS } \\
\text { Price Code } \\
\end{array}$} & \multirow[b]{2}{*}{ Page Range } & \multirow[b]{2}{*}{$\begin{array}{c}\text { Domestic } \\
\text { Price }\end{array}$} & \multirow[b]{2}{*}{$\begin{array}{c}\text { NTIS } \\
\text { Price Code }\end{array}$} \\
\hline & $\begin{array}{c}\text { Domestic } \\
\text { Price }\end{array}$ & $\begin{array}{c}\text { NTIS } \\
\text { Price Code } \\
\end{array}$ & Page Range & $\begin{array}{c}\text { Domestic } \\
\text { Price }\end{array}$ & $\begin{array}{l}\text { Microfiche } \\
\text { NTIS } \\
\text { Price Code } \\
\end{array}$ & $\begin{array}{l}3.50 \text { (A01) } \\
\text { Page Range }\end{array}$ & $\begin{array}{c}\begin{array}{c}\text { Domestic } \\
\text { Price }\end{array} \\
\end{array}$ & & & & \\
\hline $001-025$ & s 5.00 & A02 & 151-175 & $\$ 11.00$ & A08 & 301-325. & $\$ 17.00$ & A14 & $451-475$ & $\$ 23.00$ & 120 \\
\hline $026-050$ & 6.00 & A03 & $176-200$ & 12.00 & $A 09$ & $326-350$ & 18.00 & A15 & $476-500$ & 24.00 & A21 \\
\hline $051-075$ & 7.00 & A04 & 201.225 & 13.00 & A10 & $351-375$ & 19.00 & A16 & $501-525$ & 25.00 & A22 \\
\hline 076-100 & 8.00 & A0S & $226-250$ & 14.00 & All & $376+400$ & 20.00 & A17 & $526-550$ & 26.00 & 123 \\
\hline $101-125$ & 9.00 & A06 & $251-275$ & 15.00 & A12 & $401-425$ & 21.00 & A18 & $551-575$ & 27.00 & A24 \\
\hline $126-150$ & 10.00 & A07 & $276-300$ & 16.00 & A13 & $426-450$ & 22.00 & A19 & $576-600$ & 28.00 & A25 \\
\hline & & & & & & & & & 601-up & $t$ & A99 \\
\hline
\end{tabular}












Figure $\mathrm{C}$

LITHIUN

POTASSNUm (R)

$k_{2} 0$

URANIUM (R)

THORIUM (XRF)

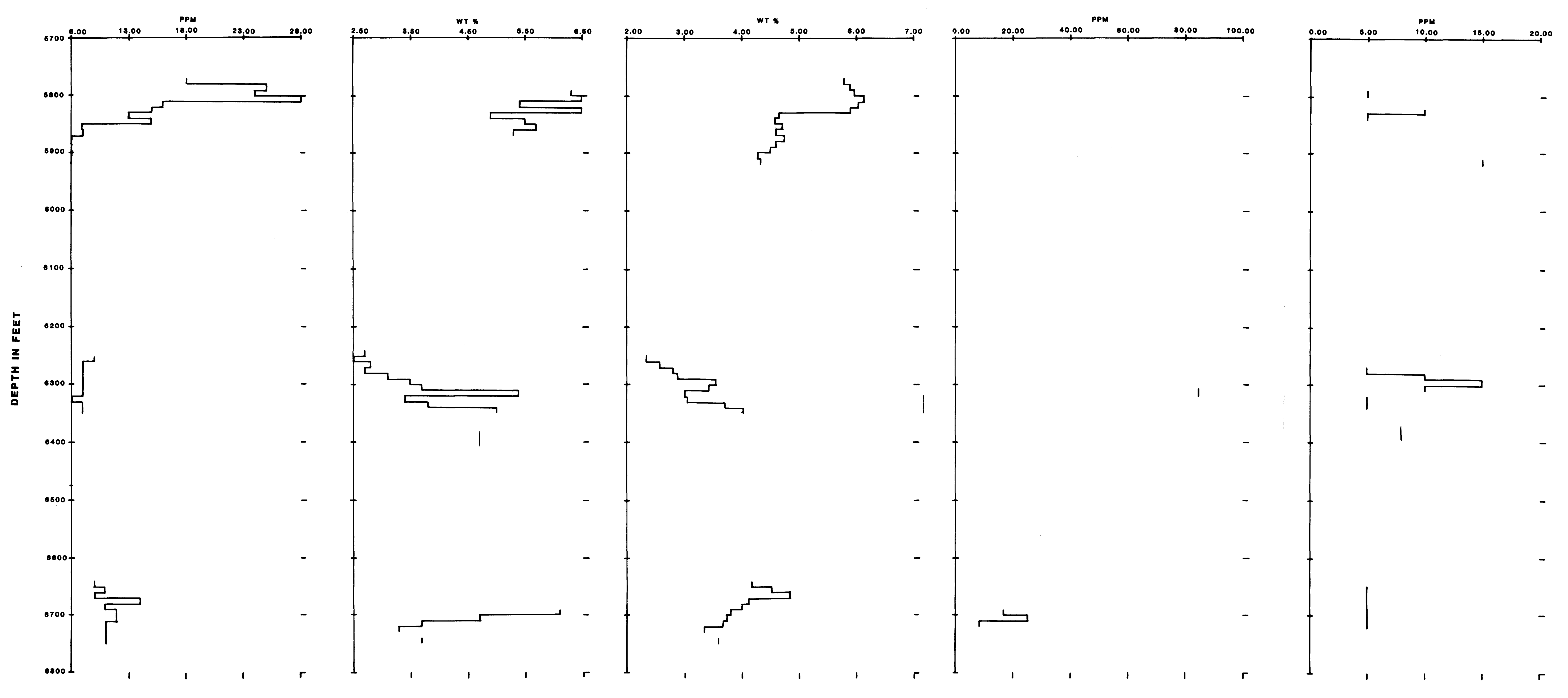

Figure C : LASL C/T-2 (Utah State Geothermal Well 9-1) Chemical, Radiometric (R) and X-Ray Florescence (XRF) Data

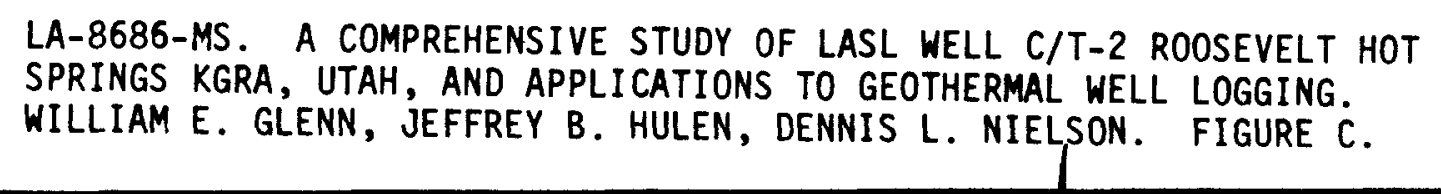


Figure D
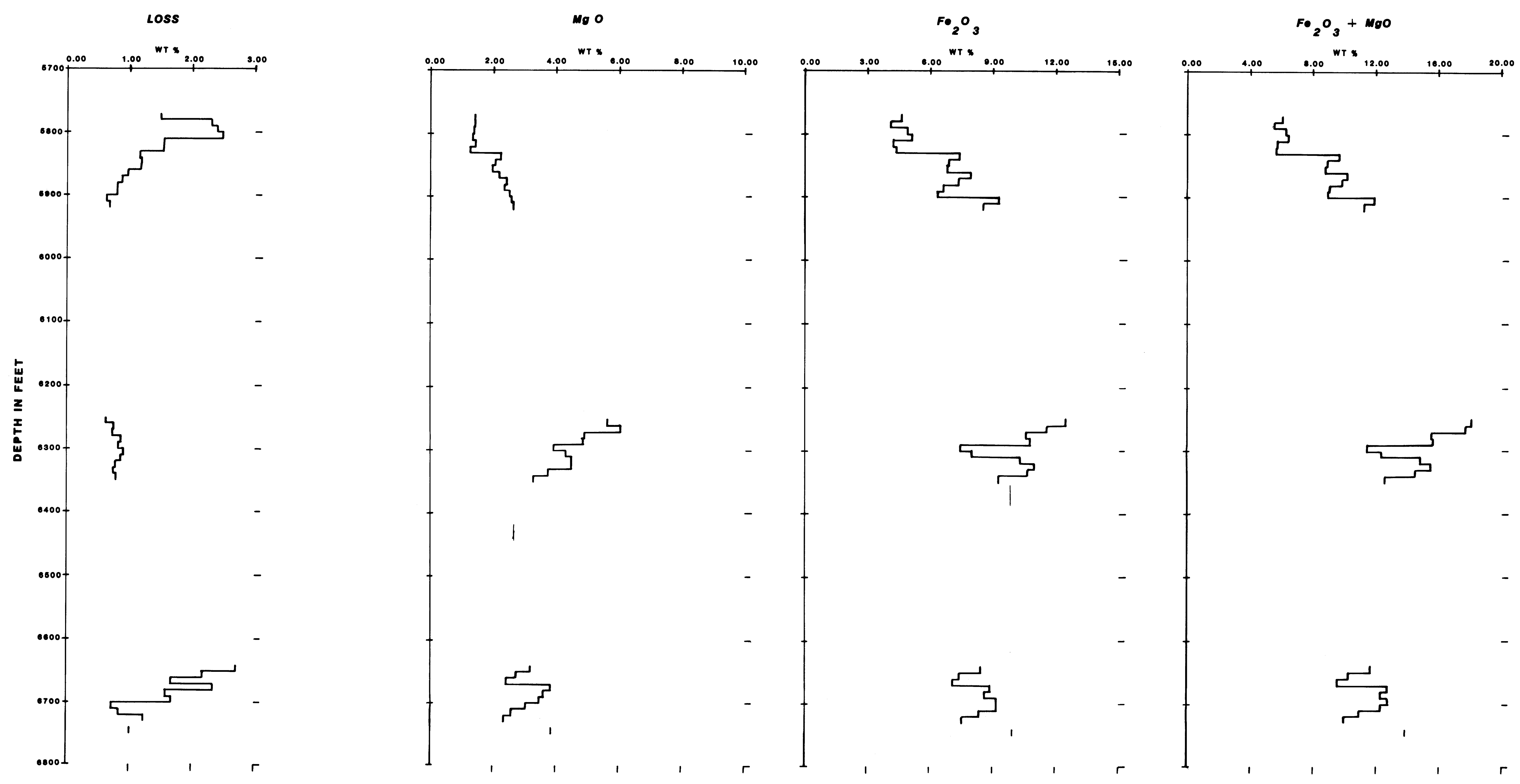

Figure D : LASL C/T-2 (Utah State Geothermal Well 9-1) Chemical Analysis

LA-8686-MS. A COMPREHENSIVE STUDY OF LAST WELL C/T-2 ROOSEVELT HOT
SPRINGS KRA, UTAH, AND APPLICATIONS TO GEOTHERMAL WELL LOGGING.
WILLIAM E. GLENN, JEFFREY B. HULEN, DENNIS L. NELSON. FIGURE D. 